Florida International University FIU Digital Commons

4-27-2018

\title{
China's Eurasian Foreign Policy: Region-Building Through State-Building Since 1991
}

Zenel Garcia

zegarc@fiu.edu

DOI: $10.25148 /$ etd.FIDC006886

Follow this and additional works at: https://digitalcommons.fiu.edu/etd

Part of the International Relations Commons

\section{Recommended Citation}

Garcia, Zenel, "China's Eurasian Foreign Policy: Region-Building Through State-Building Since 1991" (2018). FIU Electronic Theses and Dissertations. 3750.

https://digitalcommons.fiu.edu/etd/3750

This work is brought to you for free and open access by the University Graduate School at FIU Digital Commons. It has been accepted for inclusion in FIU Electronic Theses and Dissertations by an authorized administrator of FIU Digital Commons. For more information, please contact dcc@fiu.edu. 


\section{FLORIDA INTERNATIONAL UNIVERSITY}

Miami, Florida

\section{CHINA'S EURASIAN FOREIGN POLICY: \\ REGION-BUILDING THROUGH STATE-BUILDING SINCE 1991}

A dissertation submitted in partial fulfillment of the

requirements for the degree of

DOCTOR OF PHILOSOPHY

in

INTERNATIONAL RELATIONS

by

Zenel Garcia 
To: Dean John F. Stack

Steven J. Green School of International \& Public Affairs

This dissertation, written by Zenel Garcia, and entitled China's Eurasian Foreign Policy: Region-Building Through State-Building Since 1991, having been approved in respect to style and intellectual content, is referred to you for judgment.

We have read this dissertation and recommend that it be approved.

Benjamin Smith

$\begin{array}{r}\text { Jin Zeng } \\ \hline \text { Mohiaddin Mesbahi } \\ \hline \text { Thomas Breslin, Major Professor }\end{array}$

Date of Defense: April 27, 2018

The dissertation of Zenel Garcia is approved.

Dean John F. Stack Steven J. Green School of International and Public Affairs

Andrés G. Gil Vice President for Research and Economic Development and Dean of the University Graduate School

Florida International University, 2018 


\section{DEDICATION}

To my beloved mother, Mayulis Calvo, whose unwavering support in the face of adversity made it possible for me to be where I am today. 


\section{ACKNOWLEDGMENTS}

A dissertation is a single-author rite of passage. However, reaching its completion is the product of many important individuals that have helped me grow as a scholar and as a person throughout my years at Florida International University. I am grateful to my committee which has been instrumental in the development and completion of this study. I thank my advisor, Dr. Thomas A. Breslin, for his endless support and providing me with much-needed counsel. He has been a continued source of inspiration for me and I am grateful for him instilling in me a passion for history and attention to detail. His open door policy and timely feedback were crucial to my development. I would also like to thank Dr. Mohiaddin Mesbahi for his guidance and engendering in me an interest in political narratives, without which this study would not have been conceived. I am also very thankful to Dr. Jin Zeng whose feedback and advice has always been valuable to me. Finally, I am thankful to Dr. Benjamin Smith for his support.

Outside of the committee, I would also like to thank important individuals who have also had a significant impact in my development. I am very grateful to Dr. Harry D. Gould who has played an important role in my socialization into the discipline, my productivity as a scholar, and my theoretical development. I would also like to thank Dr. Susanne Zwingel whose entrance into the PIR program marked an important juncture in my development as a scholar. Furthermore, her relentless support in her capacity as Graduate Program Director during a challenging period of my graduate career is a major reason I can present this study.

My appreciation is also extended to Dr. Felix Martin, Dr. Ronald W. Cox, Dr. Astrid Arraras, Dr. Marcie Washington, and Dr. John F. Clark for aiding me in my 
academic endeavors throughout my graduate career. I would also like to extend a muchdeserved thank you to Maria W. Diaz, Martha Rodriguez, Maria Gil, Mayte Rodriguez, and Katrina Manning. Their love and support make PIR feel like a family and a home away from home. Last by not least, I would like to thank my friends and colleagues Melissa Balos, Jessy Abouarab, Bibek Chand, Onur Erpul, Saeed Mousavi, Christine Bianco, Maria Gabryszewska, Kevin Modlin, Phillip Guerreiro, Mohamed Ghumrawi, Michelle Fields, and Umer Rahman. Your friendship and encouragement made this study possible. 


\title{
ABSTRACT OF THE DISSERTATION \\ CHINA's EURASIAN FOREIGN POLICY:
}

\section{REGION-BUILDING THROUGH STATE-BUILDING SINCE 1991}

\author{
by \\ Zenel Garcia \\ Florida International University, 2018 \\ Miami, Florida \\ Professor Thomas A. Breslin, Major Professor
}

Abstract

Since the founding of the People's Republic of China in 1949, its leaders have been preoccupied with efforts to increase state capacity in order to exercise more effective control over their western frontier by controlling their minority population and generating the conditions for economic development in the area. Although these state-building initiatives have always incorporated an international component, the collapse of the USSR, the transnational characteristics of development, and China's concern around the challenges of terrorism, separatism, and extremism have necessitated an accompanying region-building project in Eurasia. Using a synthesis of the region-building approach and the concept of regionalization, this study traces how Chinese domestic elite-led narratives about security and development generate domestic state-building initiatives which in turn produce region-building projects. Furthermore, this study assesses how region-building projects are promoted through narratives embedded in foreign policies that establish the historicity of China's engagement in Eurasian affairs and norms of non-interference and 
co-development. Finally, it traces the empirical construction of regions through integrative infrastructure.

By revealing the three symbiotic phases of Chinese domestic state-building and region-building, this study demonstrates how region-building projects have facilitated China's ability to increase state capacity, control, and development in its western frontier. Furthermore, China's region-building projects have gradually transformed Eurasia in a manner that has resulted in its eastward orientation through the usage of connective infrastructure and co-development projects that place China at the center of Eurasia. This project demonstrates how China has emerged as a dominant power in Eurasian affairs that not only exercises significant political and economic power, but more importantly, ideational power.

Key Words: China, Eurasia, Foreign Policy, region-building, state-building, Belt Road Initiative 


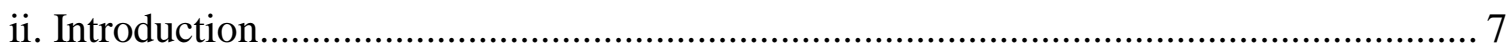

The Three Phases of China's Eurasian Region-Building Projects................................. 17

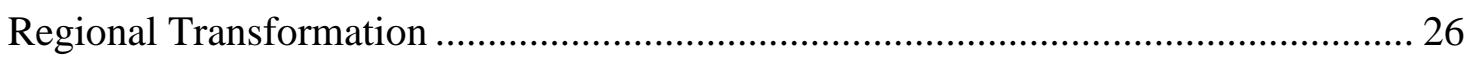

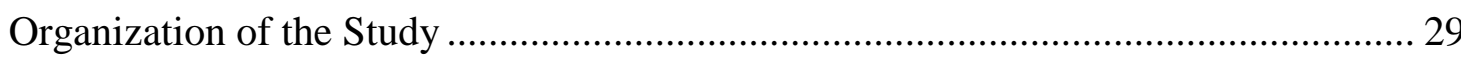

Chapter 1: Of Regions, Regionalism, Regionalization, and Region-Building ................ 32

Regionalism, Regionalization, and Regionness ........................................................ 34

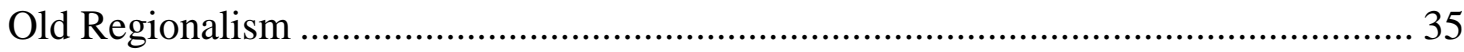

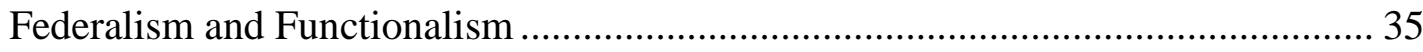

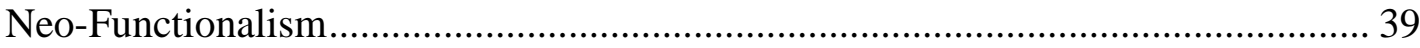

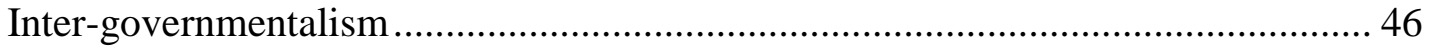

Security Communities and Complexes ................................................................... 52

Security Communities Revisited.................................................................... 56

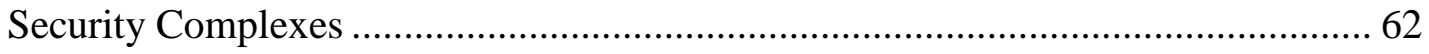

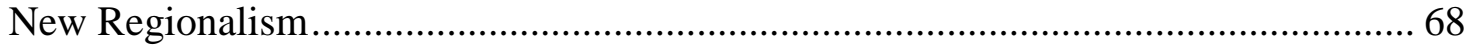

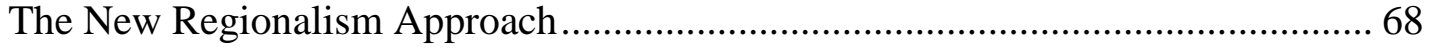

The Region-Building Approach....................................................................... 82

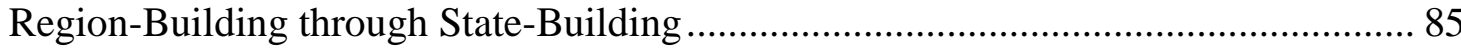

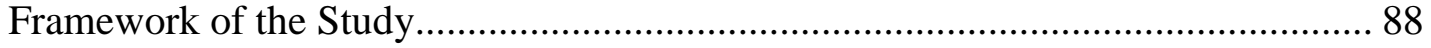

Chapter 2: 1991-2000: National Integration and Regional Formation ............................. 91

Xinjiang and the "Double-Opening" Strategy ............................................................. 96

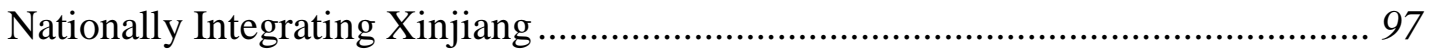

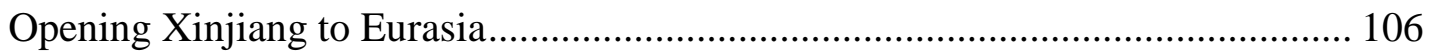

Unequal Treaties and the Sino-Soviet Split........................................................ 109

Rapprochement and Border Settlements............................................................... 118

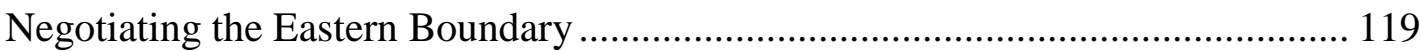

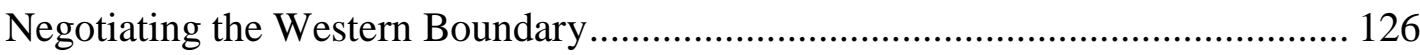

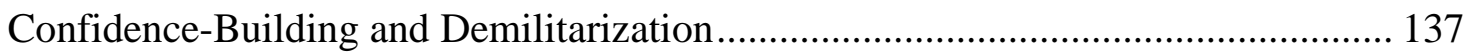

Cooperation and Coordination on the Three Evils ................................................ 142

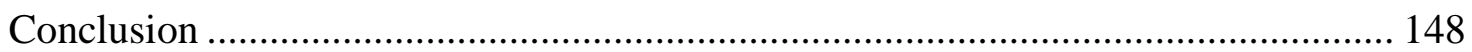


Chapter 3: 2000-2013: National Consolidation and Regional Institutionalization 151

The Great Western Development Strategy 162

Xinjiang and the Great Western Development Strategy ....................................... 171

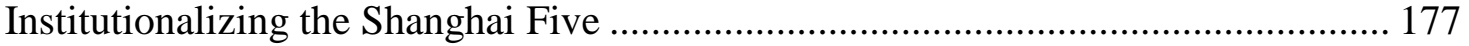

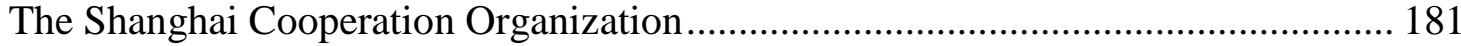

The Three Evils and the Shanghai Cooperation Organization............................... 184

The Security-Development Nexus and the Shanghai Cooperation Organization... 196

The Expansion of the Eurasian Region-Building Project ....................................... 198

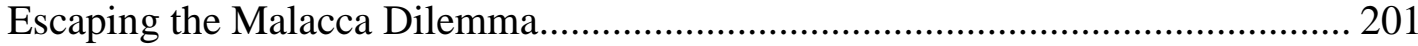

Reshaping the Eurasian Energy Landscape ........................................................ 205

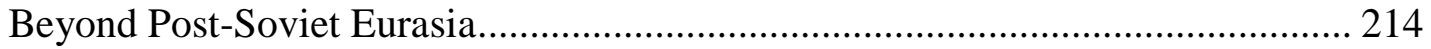

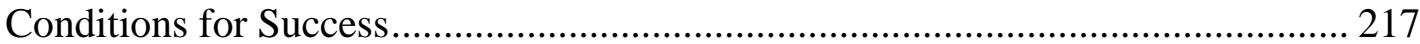

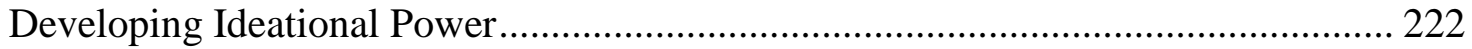

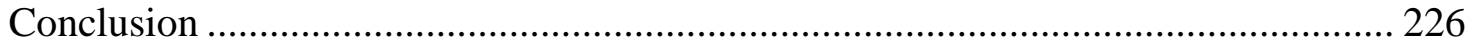

Chapter 4: 2013-Present: National Rejuvenation and Regional Transformation ........... 228

The Great Western Development and the Silk Road Economic Belt ....................... 234

The Silk Road Economic Belt and the $21^{\text {st }}$ Century Maritime Silk Road ................. 238

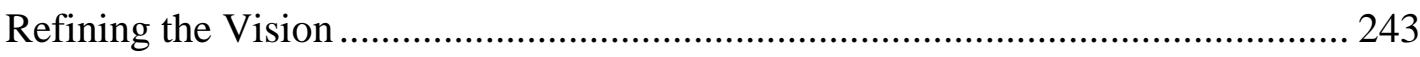

Development and Re-connecting Eurasia ........................................................ 250

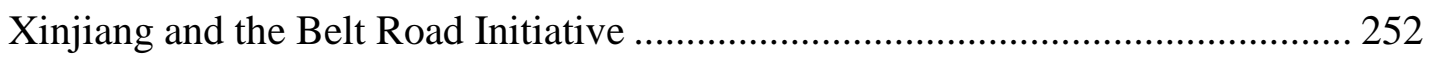

The Shanghai Cooperation Organization and the Belt Road Initiative.................. 255

Re-connecting the Eurasian Sub-Regions............................................................ 257

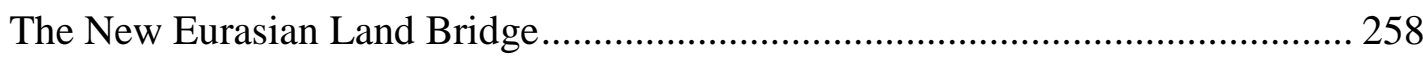

The China-Central Asia-West Asia Economic Corridor ..................................... 265

The China-Pakistan Economic Corridor .............................................................. 290

Conditions for Success.............................................................................. 300

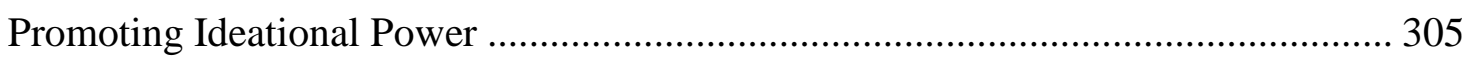

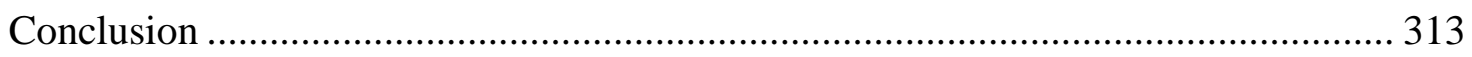

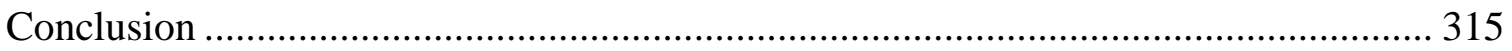

The Double-Opening and the Shanghai Five................................................... 317

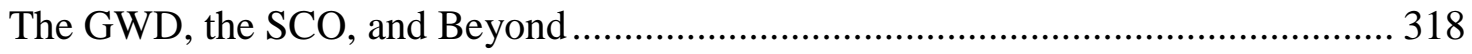


The Belt Road Initiative and Eurasian Re-Connection.......................................... 319

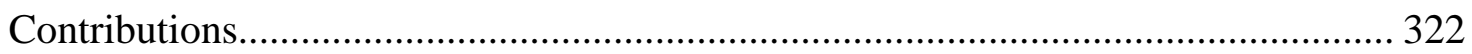

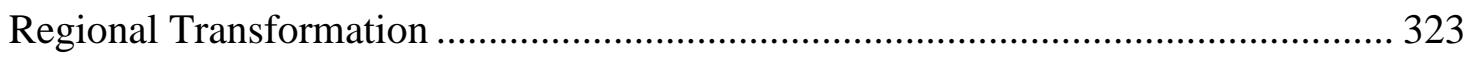

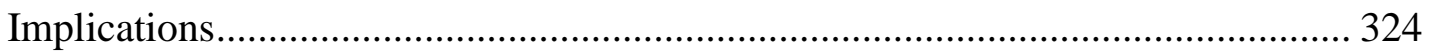

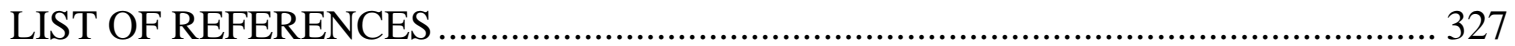

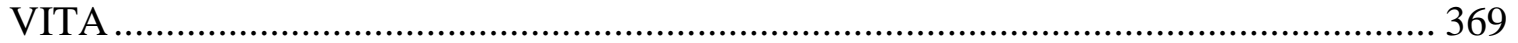




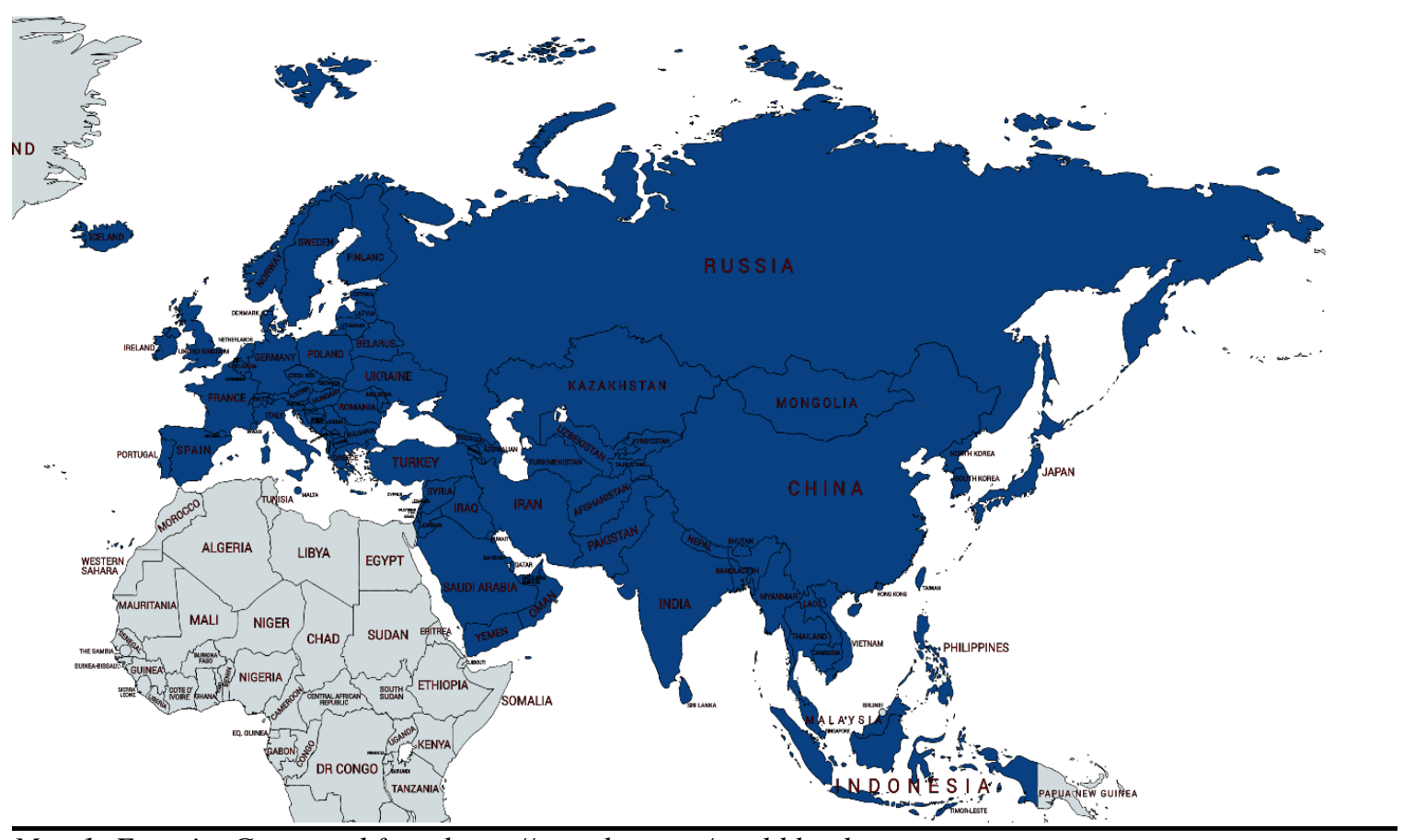

Map 1: Eurasia. Generated from https://mapchart.net/world.html

\section{i. Preface}

China's emergence as a global power has allowed it to become an important international actor. Commensurate with its rise, China has developed interests in nearly every region of the world. While China's East Asian neighborhood has traditionally been considered its "natural" region, and therefore, the most obvious place for its projection of influence and power, Beijing is increasingly looking west as it pursues state-building ${ }^{1}$ efforts that would result in the effective integration of its western frontier into the political and economic core of the country. These efforts are driving the opening of China's western frontier to the rest of Eurasia (see map 1) in order to foster political stability and economic

\footnotetext{
${ }^{1}$ This refers to the process of increasing state capacity and the ability of the state to enforce policy throughout its territory
} 
development. In other words, domestic policies aimed at national integration and consolidation are generating foreign policy initiatives that require greater Chinese engagement with its Eurasian neighbors. Consequently, domestic state-building efforts have necessitated an accompanying region-building project. $^{2}$

Although China's engagement with its Eurasian neighbors may appear to be a recent development, it has a long-standing historical precedent. Barring periods of interruption due to internal strife or foreign imperial expansion, successive Chinese governments have maintained near-constant engagement with their western neighbors for over two millennia. Furthermore, engagement with Eurasian societies and political entities, illustrated by the long history of the Silk Road, went beyond economic and cultural exchanges. By its very nature, the Silk Road possessed a powerful geopolitical component for Chinese dynasties since it was from the Eurasian steppes that their empires encountered some of the most significant challenges to their stability and security. At the same time, however, Eurasia was a source of strategic partnerships and the means to fight the constant threat from the steppes.

For example, during the Warring States period (475-221 BCE), northern Chinese kingdoms looked to the Yuezhi, a nomad confederation that held power between the eastern foothills of the Tianshan Mountains and the Turfan Depression (modern day Xinjiang), to acquire suitable quality horses for their cavalry. ${ }^{3}$ This allowed them to secure an upper hand against their rivals and allow them to cement their power base. When the Qin Shi Huangdi unified China and established the Qin Dynasty (221-206 BCE), thus

\footnotetext{
2 This refers to state narratives that drive regionalization processes

${ }^{3}$ Xinru Liu, The Silk Road in World History (Oxford: Oxford University Press, 2010), p. 3
} 
ending the Warring States period, he was faced with the challenge of the Xiongnu Confederacy that held power along the Mongolian steppes. In order to effectively fight this threat, the Emperor also turned to the Yuezhi for horses. ${ }^{4}$ Han Dynasty (206 BCE-220 CE) Emperors like Wudi (156-87 BCE) also attempted to follow this tradition in order to fight the Xiongnu as well. ${ }^{5}$ Emperor Wudi pursued a partnership with the Yuezhi and the acquisition of their "heavenly horses" in order to consolidate Han power after nearly a century of paying tribute to the Xiongnu. ${ }^{6}$ Thus, engagement with nomads from the Eurasian steppes not only provided the Chinese a means to check the power of a rival but also the tools to fight domestic rivals and cement their power. In other words, engagement with Eurasian entities facilitated domestic state-building efforts. Furthermore, records indicate that from the $6^{\text {th }}$ to $8^{\text {th }}$ century CE Tang Dynasty Emperors and kingdoms in northern India explored ways manage the rise of Tibet which on several occasions laid siege to the Tang capital. ${ }^{7}$

Parallel to engaging Eurasian societies and political entities, since $121 \mathrm{BCE}$, successive Chinese dynasties sought to protect the Hexi Corridor, which provided a direct route to the heartland of Chinese civilization, through the settlement of frontier areas. ${ }^{8}$

\footnotetext{
${ }^{4}$ Xinru Liu, The Silk Road: A Brief History with Documents (Boston: Bedford/St. Martin's, 2012), p. 5

${ }^{5}$ See: Xinru Liu, The Silk Road in World History (Oxford: Oxford University Press, 2010); Xinru Liu, The Silk Road: A Brief History with Documents (Boston: Bedford/St. Martin's, 2012)

${ }^{6}$ Xinru Liu, The Silk Road in World History (Oxford: Oxford University Press, 2010), p. 4-6

${ }^{7}$ Stewart Gordon, When Asia was the World: Traveling Merchants, Scholars, Warriors, and Monks Who Created the "Riches of the East" (Philadelphia: Da Capo Books, 2008), p. 19

${ }^{8}$ Chun-shu Chang, The Rise of the Chinese Empire: Volume II: Frontier, Immigration, \& Empire in Han China, 130B.C.-A.D. 157 (Ann Arbor: The University of Michigan Press, 2007), p. 5-8
} 
These settlements took the form of military garrisons at oasis sites in modern-day Gansu leading into present-day Xinjiang province. Soldiers were encouraged to bring their families and establish farming colonies in order to create a self-sustaining community that could protect the frontier of the empire. ${ }^{9}$ This process resulted in greater engagement between the Chinese and other Eurasian groups. As successive capitals moved westward, especially Chang'An, modern day Xian, protecting the Hexi Corridor was vital to the political and economic security of the state. This practice demonstrates another way in which China's engagement with its Eurasian neighbors played a significant role in its domestic state-building efforts to unify, consolidate, and secure the state.

However, while China's engagement with Eurasia has historical precedence, what has changed in the contemporary period is the intensity of this engagement and China's ability to influence region-wide transformation and, consequently, global dynamics. This means that although there are historical parallels in the domestic state-building efforts driving China's engagement with Eurasia, its effect on its neighbors is far more significant in modern times, especially in the context of China's emergence as a global power. Furthermore, since the collapse of the USSR, China's state-building efforts have necessitated accompanying region-building projects as its borders became increasingly complex due to Central Asian independence and the growing forces of globalization. This is especially relevant in the current Westphalian state system in which sovereignty and territorial integrity have been accepted as core international norms that have dominated interstate relations for centuries.

\footnotetext{
${ }^{9}$ Xinru Liu, The Silk Road: A Brief History with Documents (Boston: Bedford/St. Martin's, 2012), p. 7
} 
China's Eurasian region-building project, a rhetorical and empirical process built on a security-development nexus logic, is geopolitically, economically, and ideationally transforming the region, specifically through the re-connection of its sub-regions, its gradual eastward reorientation, and the facilitation of China's rise. Therefore, unlike the numerous "Silk Road" initiatives promoted by a number of states and political entities like the United States, Japan, and the European Union, China's Eurasian foreign policy since the Soviet collapse has made important progress in re-establishing formerly severed overland links between East Asia, Southeast Asia, Central Asia, South Asia, Southwest Asia, the Caucasus, and Europe. In other words, the sub-division of Eurasia, the result of imperial conquest, the "Great Game," and the Cold War, is gradually giving way due to China's region-building project, thus highlighting China's emergence as a dominant power in the region.

The implications of this development are profound. China is not only a growing continental power geographically situated in Eurasia, but it is positioning itself as the center of its re-connection process. Furthermore, China possesses the tools to transform Eurasia. Beijing holds the world's largest capital reserves and, more importantly, has the political will to engage in spaces that Western countries and institutions have avoided or have found difficulty operating in. Additionally, its adherence to non-interference has made China normatively acceptable for many Eurasian states that remain staunchly protective of their sovereignty and have reservations regarding the liberal-normative conditions that often 
present themselves when dealing with Western countries and institutions. ${ }^{10}$ Lastly, historical and international dynamics have provided a relatively permissive environment for China to effectively transform its domestic priorities into an active foreign policy agenda in Eurasia. In other words, unlike East Asia where China has little strategic space to maneuver due to continued American presence, Japanese political resurgence, and balancing behavior by a number of Southeast Asian counties, Eurasia provides a fertile ground for China to successfully accomplish domestic state-building efforts and to cement itself as a dominant power in the region. This is especially important since Russia's residual influence in the post-Soviet space is being contested, but more so, as Russia appears to have implicitly accepted a junior partnership role in the region. ${ }^{11}$ In other words, China's region-building project, expressed through its foreign policy, has had a transformative effect on Eurasia since the dissolution of the USSR, which has important implications for China's place in the international system.

Understanding this dynamic is critical, particularly in the context of China's rise, since it provides an opportunity to assess the processes that shape its vision for regional and, potentially, global order. Consequently, this study analyzes how elite narratives within China's Communist Party shape state-building initiatives and how these narratives are externalized through region-building projects that serve to facilitate domestic control and

\footnotetext{
${ }^{10}$ See: Alexander Cooley, Great Games, Local Rules: The New Great Power Contest in Central Asia (Oxford: Oxford University Press, 2012), p. 77; Bernardo Mariani, "China's Role and Interests in Central Asia," Saferworld, 2013, p. 9, https://www.files.ethz.ch/isn/172938/chinas-role-and-interests-in-centralasia.pdf

${ }^{11}$ Alexander Cooley and Marlene Laruelle, "The Changing Logic of Russian Strategy in Central Asia: From Privilege Sphere to Divide and Rule?" PONARS Eurasia 261, 2013, http://www.ponarseurasia.org/sites/default/files/policy-memos-pdf/Pepm_261_CooleyLaruelle_July\%202013.pdf
} 
economic development. In essence, it aims to unearth the rhetorical and empirical processes that link state-building initiatives to region-building projects. This not only provides a better insight into how Chinese domestic interests are translated into international ones, and consequently a foreign policy, but also how great powers influence regional formation and transformation through this process.

\section{ii. Introduction}

The Tang defeat at the hand of Abbasid Caliphate forces in the Battle of Talas (751 CE) has often been portrayed as the event that halted Chinese westward expansion into Central Eurasia (see map 2). ${ }^{12}$ However, as a result of its conquest of Xinjiang, an effort begun with the Han Dynasty but not sufficiently cemented until the Qing conquests in the $18^{\text {th }}$ century $^{13}$, China effectively acquired a gateway into its hinterland (see map 3 ). This gateway is important for understanding China's state-building efforts as well as its regionbuilding project for two interrelated reasons.

The first is the security-development nexus logic that the Chinese Communist Party (CCP) has internalized and incorporated into its domestic development strategy. In essence, the CCP correlates economic development in Xinjiang with stability, in the sense that development is perceived to mitigate ethnic tensions and undermine terrorist, separatist,

\footnotetext{
${ }^{12}$ See: Jaques Gernet, A History of Chinese Civilization (Cambridge: Cambridge University Press, 1982), p. 287; Svat Soucek, A History of Inner Asia (Cambridge: Cambridge University Press, 2000), p. 68

${ }^{13}$ See: Dazheng Ma, “The Tarim Basin,” in History of Civilizations of Central Asia: Volume V Development in Contrast: from the Sixteenth to the Mid-Nineteenth Century, eds. Chahryar Adle, Irfan Habib, and Karl M. Baikapov (Paris: UNESCO Publishing 2003); K. Warikoo, "Xinjiang under the Qings," in Xinjiang - China's Northwest Frontier, ed. K. Warikoo (NY: Routledge 2016)
} 
and extremist movements in this province. ${ }^{14}$ The logic is explicitly co-constitutive: development brings stability which consequently facilitates development. Although it is unclear which component is seen by the CCP as being a sufficient condition to initiate this "virtuous cycle", it is evident that it sees itself as playing the central role of providing both of these components. Furthermore, as this study will demonstrate in the following chapters, this security development nexus logic has become externalized as state-building efforts have become increasingly dependent on a region-building component in order to increase the likelihood of their success. Consequently, the logic is expanded to mean that the development of Xinjiang, and other western provinces, requires entry into markets which can only be accessed by incorporating Eurasia into China's greater economic zone. Therefore, by investing in Eurasia's development, the CCP believes it can maintain regional political and economic stability which ultimately facilitates state-building efforts to control and develop Xinjiang, thus attenuating ethnic tensions in this traditionally restive province. In other words, development and stability in Xinjiang is contingent on development and stability in Eurasia and vice versa.

The second reason is that Xinjiang serves as the hub that connects China's underdeveloped western and central provinces to Eurasian markets, thus facilitating the establishment of new supply chains and aiding the CCP's effort to close the gap between its Eastern and interior provinces. Thus, the rhetorical and empirical processes of China's

\footnotetext{
${ }^{14}$ See: "National Work Conference of the Central Committee of the Chinese Communist Party and the Sixth National Commendation Meeting for National Unity and Progress held in Beijing," Xinhua News, September 29, 2014, http://news.xinhuanet.com/politics/2014-09/29/c_1112683008.htm ; "China Voice: Quality of Life Key to Xinjiang Unity," Xinhua News, May 6, 2014, http://news.xinhuanet.com/english/indepth/2014-05/06/c_133314387.htm; Malika Tukmadiyeva, "Xinjiang in China's Foreign Policy Toward Central Asia," The Quarterly Journal, Summer 2013, p. 87-107
} 
region-building efforts, expressed through its foreign policy, are dominated by explicitly domestic imperatives that originate from the relationship between security, social stability and economic development. However, China's ability to pursue a region-building project in Eurasia is not solely contingent on its ability to project material and ideational power, it is also dependent on a permissive international environment that enables engagement. This opportunity presented itself at the end of the Cold War.

The collapse of the USSR, while initially posing numerous challenges for the PRC, ${ }^{15}$ ultimately provided Beijing the opportunity to directly engage its western neighbors. The Soviet collapse meant that there were now multiple actors on China's western frontier, as opposed to a unitary superpower, which it could more effectively engage. After initial differences were addressed through border negotiations and confidence-building mechanisms, many of the new republics became receptive to Beijing's overtures particularly in areas of economic investment and cooperation on key transnational security issues. Furthermore, despite its significant residual political and economic influence in the region, the Russian Federation, the successor state of the USSR, was no longer in a position to single-handedly control the political and economic orientations of the former republics. In other words, the collapse of a single unitary Soviet entity threw open China's western frontier and presented it with the opportunity to link the

\footnotetext{
${ }^{15}$ See: Pablo A. Rodriguez, "Violent Resistance in Xinjiang (China): Tracking Militancy, Ethnic Riots and 'Knife-Wielding' Terrorist (1972-2012)," Historia Actual Online 30, 2013, http://www.historiaactual.org/Publicaciones/index.php/haol/article/view/820/672; Elizabeth Van Wie Davis, "Uyghur Muslim Ethnic Separatism in Xinjiang, China," Asia-Pacific Center for Security Studies, 2008, $\mathrm{http} / / /$ apcss.org/college/publications/uyghur-muslim-ethnic-separatism-in-xinjiang-china/
} 
regional markets of Xinjiang and western China with those of Russia, Central Asia, as well as with South Asia, Southwest Asia, and Europe through overland corridors.

Immediately after the Soviet collapse, China's policy in the region focused on concerns over the delimitation, demarcation and demilitarization of borders. ${ }^{16}$ This was motivated by a number of important domestic and international imperatives. The first of those was the need to finally settle its border with the Russian Federation and the newlyformed Central Asian republics in a legally binding mechanism in order to legitimize Chinese sovereignty over Xinjiang. This would also allow for the reduction of forces at the border, thus freeing up resources for Beijing's domestic development strategy, something that was considered critical in the context of security and regime stability. Lastly, and perhaps the most important, was the reduction of insecurity emanating from the Uyghur diaspora residing in its western neighbors, that in the past had undermined stability in Xinjiang, through cooperation with its western neighbors against terrorism, separatism, and extremism, the "three evils." Furthermore, as this study will demonstrate, since 1991 China's engagement with its Eurasian neighbors has expanded and deepened across several sectors. In other words, the Soviet collapse facilitated China's state-building efforts of integrating and developing Xinjiang through the initiation of a region-building project that sought to normalize relations with its Eurasian neighbors and socialize them into China's orbit. Consequently, China has not only become embedded in Eurasia, it has also become the driver of its transformation. China's ability to establish itself so prominently in the

\footnotetext{
${ }^{16}$ See: "Charter of the Shanghai Cooperation Organization," Official Website of Russia's Presidency in the Shanghai Cooperation Organization 2014-2015, June 7, 2001, http://en.sco-russia.ru/documents/; "Joint Communique of Meeting of Council Heads of SCO Members," Ministry of Foreign affairs of the People's Republic of China, August 23, 2007, http://www.fmprc.gov.cn/mfa_eng/wjdt_665385/2649_665393/t355665.shtml
} 
region is the result of its prudent approach to engaging its Eurasian neighbors as well as global events that have facilitated its advances. The process of China's emergence as a dominant power in Eurasia can be evidenced geopolitically, economically, and ideationally during three distinct, yet evolutionary, phases of China's Eurasian region-building projects.

Geopolitically, China has been successful in promoting its securitization narratives in Eurasia, particularly regarding transnational security issues of terrorism, separatism and extremism, the "three evils," which are of major domestic importance for the CCP. Its Central Asian neighbors, being politically and economically unstable after independence, possessed similar concerns, and thus found common ground with China's initiative for cooperation. In addition, China's emergence as a global power has made it a valuable strategic partner for Eurasian states seeking political diversification from Russia, the United States, and the European Union. This indicates that Eurasian states are not passive bystanders in the great power struggle for influence in their region; they possess significant agency and play the key role of facilitators for China's Eurasian engagement. At the same time, despite Russia's concern that China may displace it from its traditional leadership position in the post-Soviet space, ${ }^{17}$ it finds itself with few international partners, particularly in the aftermath of its war with Georgia in 2008 and its annexation of Crimea in 2014. As a result, Russia has had to rely on China as its primary political and economic partner for the foreseeable future, thus limiting any efforts to undermine China's

\footnotetext{
${ }^{17}$ Alexander Warktotsch, "The Caspian Region: The Struggle for Resources," in The Neighbors of the European Union's Neighbors: Diplomatic and Geopolitical Dimensions Beyond, eds. Sieglinde Gstohl and Erwan Lannon (Burlington: Ashgate Publishing Company 2014) p. 181-199
} 
ascendance in the region. ${ }^{18}$ Furthermore, actual and perceived efforts to interfere in the domestic and international affairs in the post-Soviet space have made many Eurasian republics wary of Russia. Lastly, America's and Europe's efforts to attach liberalnormative conditions to aid and assistance, such as political, market, and financial-sector liberalization, have made them less-than-ideal partners for Eurasian states, many of which maintain non-liberal regimes. It is here that China's normative appeal begins to play an important role in its success in establishing itself as a major player in Eurasian affairs.

Economically, China's emergence as the second largest economy in the world and its massive foreign reserves have provided Beijing with significant financial resources to pursue investments that would have traditionally been made by Western states and Western-led financial institutions like the World Bank or the Asian Development Bank. In fact, China has almost managed to match the official funding given by the United States to other countries since the turn of the $21^{\text {st }}$ century. ${ }^{19}$ As a result, China has become the most important trade partner for a number of states in Eurasia, many of which rank as some of the least-free economies and are generally considered poor investment destinations. ${ }^{20}$ Consequently, not only has China surpassed Russia as the primary investor in Central

\footnotetext{
${ }^{18}$ Alexander Gabuev, "Friends with Benefits?: Russian-Chinese Relations After the Ukrainian Crisis," Carnegie Moscow Center, June 29, 2016, http://carnegie.ru/2016/06/29/friends-with-benefits-russianchinese-relations-after-ukraine-crisis-pub-63953

${ }^{19}$ Adam Taylor, "China treats its foreign aid like a state secret. New research aims to reveal it," The Washington Post, October 11, 2017, https://www.washingtonpost.com/news/worldviews/wp/2017/10/11/china-treats-its-foreign-aid-like-a-statesecret-new-research-aims-to-reveal-it/?utm_term=.c812a4b34228

20 "Index of Economic Freedom 2017," The Heritage Foundation, 2017, http://www.heritage.org/index/ranking
} 
Asia,${ }^{21}$ but is a key trade partner for the European Union, Russia, and pivotal Eurasian states like Iran and Pakistan. ${ }^{22}$ Additionally, China's push for greater regional interconnectivity through infrastructure projects, spearheaded by "The Silk Road Economic Belt and the $21^{\text {st }}$ Century Maritime Silk Road" and the Asian Infrastructure and Investment Bank, presents an opportunity for Eurasian states to complete critical infrastructure projects that improve inter-regional linkages and enhance their ability to profit from north-south and east-west economic corridors. ${ }^{23}$ Lastly, much like the geopolitical dimension, China's policy of non-interference makes it a natural economic partner for many of Eurasia's non-democratic regimes since its investments do not come with many of the liberal-normative conditions that are present in American and European offers. Furthermore, China's willingness to offer resource-backed loans to Eurasian states allows many of these countries to use their natural endowments to pay for projects without the need to draw on their hard currency reserves. ${ }^{24}$ In other words, Chinese investment provides recipients with a level of flexibility that other sources do not allow.

\footnotetext{
${ }^{21}$ Alexander Cooley, "China's Changing Role in Central Asia and Implications for US Policy: From Trading Partner to Collective Goods Provider," U.S.-China Economic and Security Review Commission, March 18, 2015, http://www.uscc.gov/sites/default/files/Cooley\%20Testimony_3.18.15.pdf

${ }^{22}$ See: "Russia," CIA World Factbook, 2017, https://www.cia.gov/library/publications/the-worldfactbook/geos/rs.html; "Iran," CIA World Factbook, 2017, https://www.cia.gov/library/publications/theworld-factbook/geos/ir.html; "Pakistan," CIA World Factbook, 2017, https://www.cia.gov/library/publications/the-world-factbook/geos/pk.html

${ }^{23}$ Johannes Linn, "Central Asia Regional Integration and Cooperation: Reality or Mirage?," in Eurasian Integration Yearbook 2012, eds. Evgeny Vinokurov (Eurasian Development Bank), p. 96-117

${ }^{24}$ Andrew Bracken, Christina Hajj, Kristy Hartman, and Shivan Sivalingam, "China's Quest for Energy Security: Redefining and Driving Foreign Aid: An Analysis of China's Involvement in Central Asia and Africa," Policy Reports, Ford School University of Michigan, 2012, http://sites.fordschool.umich.edu/china-policy/files/2012/09/oil-and-aid-CHINA-FINAL-PAPER.pdf
} 
Ideationally, China's gains have been modest. This is due to two important challenges. The first challenge is the overwhelming cultural advantage Russia possesses in the post-Soviet space, particularly the usage of Russian as a lingua-franca, as well as the ethnic Russian communities that remained after the collapse of the USSR. Beyond the postSoviet sphere, China competes with the US, EU, and other regional neighbors like Japan and South Korea for cultural influence on the global stage. This compounds the second challenge since China has experienced numerous difficulties in exporting its cultural products despite concerted efforts to emulate the successes of its neighbors Japan and South Korea. ${ }^{25}$

Notwithstanding these challenges, China has been making inroads to build and strengthen ideational power in Eurasia. This is because the political and economic conditions in the post-Soviet space have prompted ethnic Russians to leave the region for the Russian Federation. ${ }^{26}$ In addition, the prevalence of Russian as a spoken language in these areas has diminished as a result of generational changes as well as the growing appeal of studying in China as opposed to Russia. Therefore, while the decrease of Russophiles in the post-Soviet space is not directly caused by China's emergence as a player in the region, it has had an accelerating effect. Furthermore, concerted efforts by the Chinese government

\footnotetext{
${ }^{25}$ George Gao, "Why is China So...Uncool? Foreign Policy, March 8, 2017, http://foreignpolicy.com/2017/03/08/why-is-china-so-uncool-soft-power-beijing-censorship-generationgap/

${ }^{26}$ See: Sebastien Peyrouse, "The Russian Minority in Central Asia: Migration, Politics, and Language," Kennan Institute Occasional Paper \# 297, 2008, https://www.wilsoncenter.org/sites/default/files/OP297.pdf; Victoria Panfilova, "Russian Exodus Continues from Central Asia," Russia \& India Report, August 25, 2014, http://in.rbth.com/world/2014/08/25/russian_exodus_continues_from_central_asia_37791; Paul Goble, "Ethnic Russians Leaving Central Asia and Them, Putin's Hopes for Influence," Eurasia Daily Monitor 13(22), 2016, https://jamestown.org/program/ethnic-russians-leaving-central-asia-and-with-them-putinshopes-for-influence/
} 
to establish Confucius Institutes in this region, as well as its willingness to grant numerous scholarships to students from these countries, increase the appeal of Chinese language and culture and help strengthen regional ideational links. Lastly, while the appeal of Chinese culture may be limited abroad, China's non-liberal normative approach to inter-state relations may allow it to spread its developmental model. In other words, here again China's non-interventionist foreign policy and no-strings-attached economic investment model help China improve its international normative appeal and, consequently, its ideational power.

These three dimensions demonstrate how China's region-building project, driven by domestic state-building efforts, and shaped by international dynamics, is resulting in the transformation of Eurasia. In essence, a process of re-connection of the Eurasian subregions has begun as a result of increased connectivity galvanized by China's appeal to a common interest in the realm of security and economic development. However, it is important to note that this increased connectivity that has emerged as a result of China's region-building projects should not be interpreted as the emergence of a supranational entity like the European Union. The republics in Eurasia remain highly protective of their sovereignty even as they are becoming increasingly interdependent and eastward-oriented due to China's dominant role in the region's transformation. 


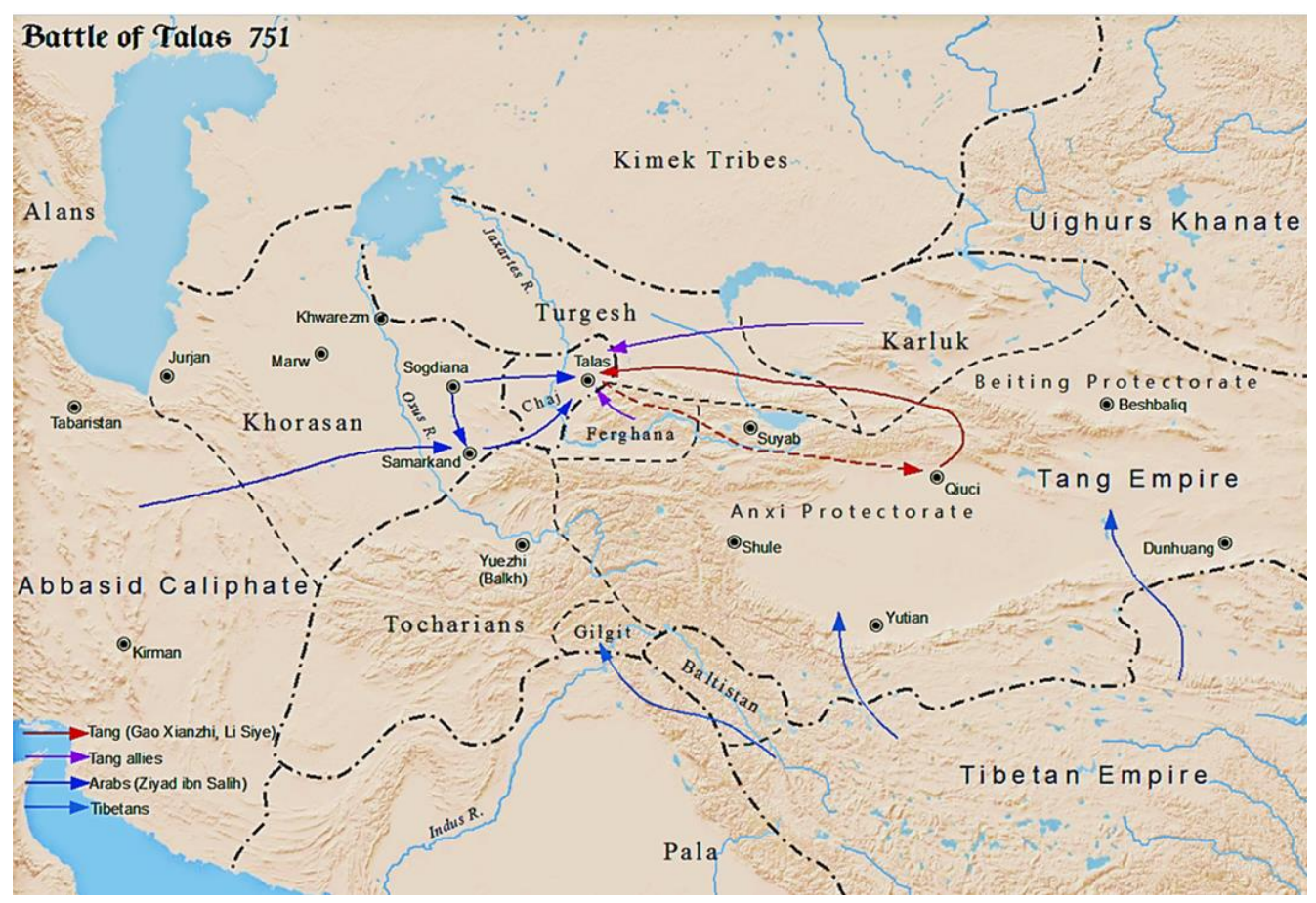

Map 2: Battle of Talas (751CE). Source:

https://en.wikipedia.org/wiki/Battle_of_Talas\#/media/File:Battle_of_Talas.png

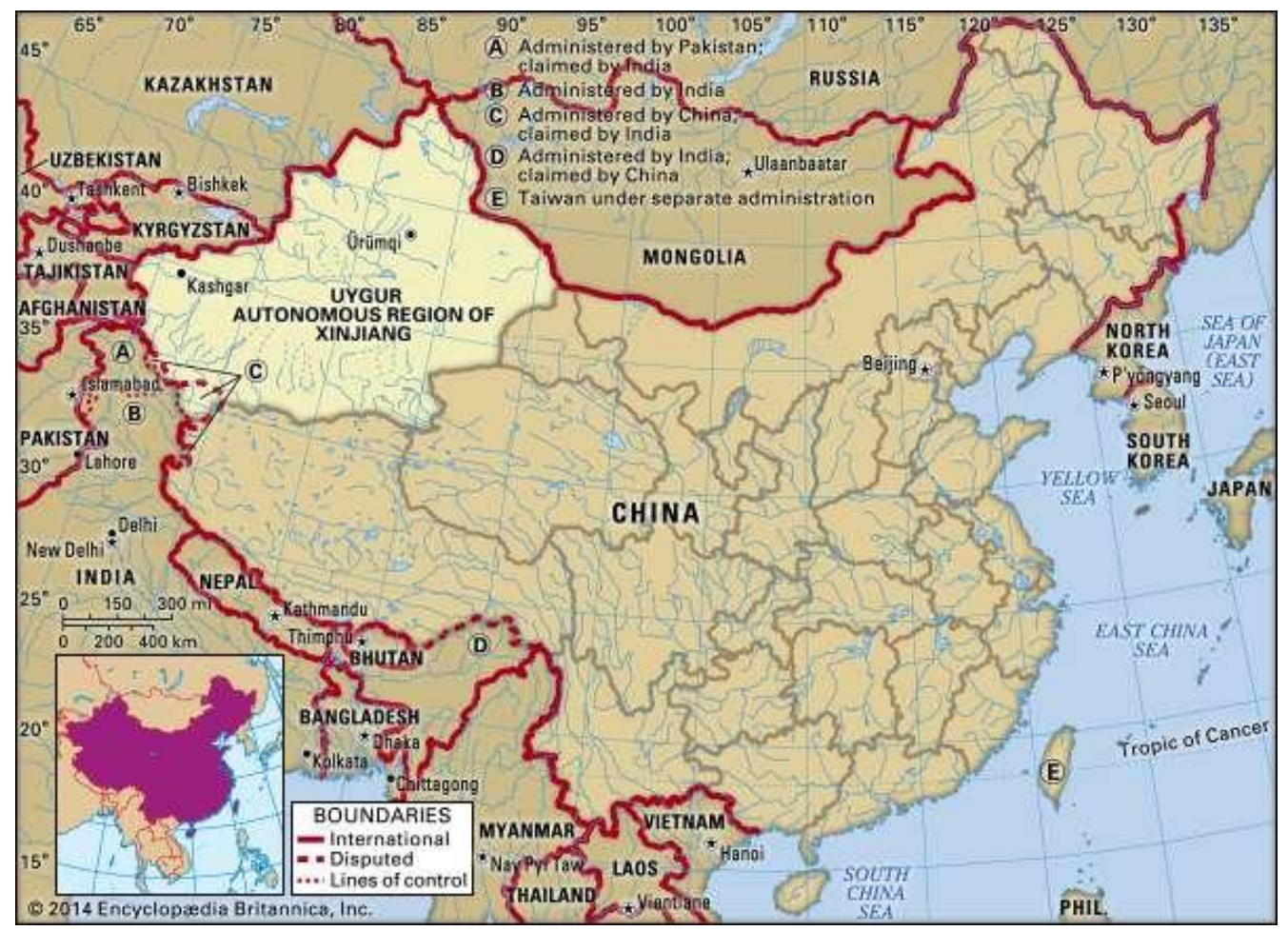

Map 3: Xinjiang Uyghur Autonomous Region. Source: https://www.britannica.com/place/Xinjiang 


\section{The Three Phases of China's Eurasian Region-Building Projects}

This study aims to unearth the rhetorical and empirical processes that link China's domestic state-building initiatives to its Eurasian region-building projects. To demonstrate these processes, this study distinguishes between three distinct, yet cumulative, phases of Chinese region-building projects Eurasia. The first phase occurred between 1991 and 2000. This period coincided with the collapse of the USSR and the initial disruptive forces that it unleashed, internally and externally, for the Chinese leadership. This phase was marked by collective efforts to demarcate the borders between the People's Republic of China (PRC) and its newly-formed neighbors: the Russian Federation, Kazakhstan, Kyrgyzstan, and Tajikistan. Additionally, these five states, informally known as the "Shanghai Five" sought to ease Cold War-era tensions and demilitarize their respective borders and build confidence among themselves. It was during this period that China began to push for formal cooperation on the "three evils" of terrorism, separatism, and extremism, something that required the socialization of its neighbors into its securitization process. China's pivotal role in these processes was primarily motivated by important domestic imperatives. In essence, this phase coincides with the "Double-Opening" strategy, a state building initiative, aimed at simultaneously integrating Xinjiang into the political and economic core of the country, as well as opening its economy to the rest of Eurasia, in order to promote political and social stability and economic development. Therefore, during this phase China's Eurasian policy was focused on the normalization of relations with its postSoviet neighbors in order to ensure that its state-building efforts in Xinjiang were successful. 
This period of normalization was facilitated by a number of important international factors. The first was the structural change that occurred following the collapse of the USSR. Thus, the PRC no longer had to deal with a Eurasian superpower, but instead, it was dealing with a weakened Russia and three, newly-formed, fragile, Central Asian republics. The second was the economic collapse that accompanied the dissolution of the USSR which necessitated the swift demarcation of borders and the guarantee of national sovereignty in order to justify the end of the costly forward deployment of armed forces along the border. ${ }^{27}$ This was also something that economically benefitted China since it also had to maintain high levels of troop deployments along the border to meet the Soviet threat. Reducing these numbers would free up valuable resources that could be used for further economic development. ${ }^{28}$ The third was the general restraint shown by Chinese negotiators during border negotiations, which helped build confidence among the parties involved. ${ }^{29}$ Finally, China's non-interventionist norms allowed it to establish stable relations with the newly formed republics in Central Asia which in turn allowed these states to facilitate China's engagement in Eurasia beyond these republics. In other words, the initial disruption caused by the Soviet collapse gradually transformed into a strategic opportunity for China.

\footnotetext{
${ }^{27}$ Allen Carlson, Unifying China, Integrating the with the World: Securing Chinese Sovereignty in the Reform Era (Stanford: Stanford University press, 2005), p. 67

${ }^{28}$ Samuel S. Kim, "Mainland China in a Changing Asia-Pacific Regional Order," in Contemporary China in the Post-Cold War Era, eds. Bih-jaw Lin and James T. Myers (Columbia: University of South Carolina Press, 1996), p. 263-305

${ }^{29}$ Allen Carlson, Unifying China, Integrating with the World: Securing Chinese Sovereignty in the Reform Era (Stanford: Stanford University press, 2005), p. 66
} 
The second phase occurred from 2000 to 2013. While the first phase was dominated by the normalization of relations between the PRC and its post-Soviet neighbors, the second marked a period of deepening Sino-Eurasian engagement as a result of a greater push by the CCP to develop its western frontier. At the turn of the millennium, the CCP began its "Great Western Development" strategy, another state-building initiative. This campaign provided a comprehensive framework for developing China's most underdeveloped provinces and narrowing the income gap between the coastal regions and the hinterlands. Xinjiang played a pivotal role in the nation's Great Western Development strategy since it served as the Eurasian continental landbridge, thus connecting China's western regions with regional markets and energy resources of Eurasia. ${ }^{30}$ Much like the efforts of the 1990s, this state-building effort sought to continue Xinjiang's integration into the rest of China while simultaneously opening it to its western neighbors. Effectively doing this, however, necessitated greater levels of cooperation from Eurasian states. As a result, it was during this phase that China began to push for the institutionalization of the informal summits conducted under the "Shanghai Five" grouping. This institutionalization marked the formation of the Shanghai Cooperation Organization (SCO) which strengthened cooperation against the "three evils" and institutionalized the norm of noninterventionism and a consensus-based approach to inter-state relations among members. ${ }^{31}$

\footnotetext{
${ }^{30}$ Michael Clarke, "China's Integration of Xinjiang with Central Asia: Securing a "Silk Road" to Great Power Status?” China and Eurasia Forum Quarterly 6(2), 2008, p. 89-111

${ }^{31}$ Xiaodong Zhao, "The Shanghai Cooperation Organization and Counter-Terrorism Cooperation," Institute for Security \& Development, 2012, http://isdp.eu/content/uploads/publications/2012_zhao_the-shanghaicooperation-organisation.pdf
} 
Consequently, the SCO has served as a platform to legitimize China's geopolitical and economic engagement in Eurasia. ${ }^{32}$ It was here that China's region-building project in Eurasia became more explicit and formal.

During this period, China also became heavily invested in Central Asia, particularly in the hydrocarbon sector. This investment was motivated by three important yet interrelated dynamics. The first was that during this period the CCP sought to exploit Xinjiang's hydrocarbon resources for local consumption as well as making it a refining hub for Eurasian hydrocarbons. This was motivated by the need to promote industrialization and economic development in the region. ${ }^{33}$ The second was that by its very growth, the Chinese economy was increasing overall domestic demand, thus necessitating greater levels of energy imports. ${ }^{34}$ The third was the recognition that China's overreliance on oversea energy imports was at the mercy of American maritime power. In effect, the existence of a "Malacca Dilemma" motivated CCP officials to promote overland pipeline investments in Eurasia in order to diversify not only the source of energy imports but also the routes away from the maritime commons. ${ }^{35}$ In other words, a state-building

\footnotetext{
32 Jong-Dong Yuan, "China's Role in Establishing and Building the Shanghai Cooperation Organization (SCO)," Journal of Contemporary China 19(67), 2010, p. 855-869

${ }^{33}$ Michael Clarke, "China's Integration of Xinjiang with Central Asia: Securing a "Silk Road" to Great Power Status?" China and Eurasia Forum Quarterly 6(2), 2008, p. 89-111

${ }^{34}$ Sharif Shuja, "China's Energy needs and Central Asia," National Observer 67, Summer 2006, http://www.nationalobserver.net/2006_sharif_summer.htm

${ }^{35}$ Chas W. Freeman Jr., "Energy as China's Achilles Heel?" in China's Energy Strategy: The Impact on Beijing's Maritime Policies, eds. Gabriel B. Collins, Andrew S. Erickson, Lyle J. Goldsteing, and William S. Murray (Annapolis: Naval Institute Press, 2012), p. 13-20
} 
imperative continued to be the driving force behind China's Eurasian region-building project.

Apart from China's economic and geopolitical interests, this phase also marked Beijing's initial efforts to comprehensively develop ideational power through the promotion of cultural exchanges, Mandarin language, and the establishment of Confucius Institutes. ${ }^{36}$ Starting in Tashkent in 2005, the PRC began a concerted effort to open Confucius Institutes in key Eurasian cities. By the end of 2009, every Central Asian republic, barring Turkmenistan, as well as Russia, Afghanistan, Iran, and Pakistan, had a Confucius Institute. ${ }^{37}$ Additionally, every single Transcaucasian republic had established one by $2011 .^{38}$ These institutes not only provide a place through which cultural exchanges and Mandarin lessons can be more effectively managed, they also provide scholarships for students in these countries to study in China. In other words, Confucius Institutes provide the foundation for increasing the number of Sinophiles in the region. More importantly, however, during this period China became increasingly proactive in expressing its norms of non-interference and support of pluralism of development systems, particularly through the platform provided by the SCO.

This period of institutionalization and hydrocarbon investment was facilitated by a number of factors. The first, was that this period coincided with China's meteoric economic rise. At the end of the first decade of the $21^{\text {st }}$ century, China emerged as the second largest economy and the most dynamic industrial center. As a result, many countries in Eurasia

\footnotetext{
36 “About Confucius Institute/Classroom,” Hanban, http://english.hanban.org/node_10971.htm

${ }^{37}$ Ibid.

${ }^{38}$ Ibid.
} 
began to perceive China as a serious economic alternative to other major sources of investment such as Russia, the United States, and the European Union, as well as international financial institutions such as the World Bank and the International Monetary Fund. This became more pronounced after the global financial crisis during which American leadership of the global economic order waned, its leaders became increasingly inward focused, ${ }^{39}$ and the E.U. was in deepening financial crisis, while China emerged largely unscathed ${ }^{40}$ Furthermore, while the U.S. and the E.U. pursued a series of large investments in the region after the collapse of the USSR, these projects have either not materialized or have not yielded the desired returns. ${ }^{41}$ Lastly, the tendency of western-led financial institutions to push for liberal-normative conditions on their aid and investment made them less than ideal partners for many of the region's non-liberal regimes. China's non-liberal normative approach, coupled with the payment flexibility offered by resourcebacked loans, allowed it to exploit the strategic economic opening caused by these conditions. The second factor, which is more relevant for the post-Soviet republics, is the deterioration of relations with many states due to Russia's efforts to leverage its political and economic power in the region. As a result, many of the states in the region sought a measure of political and economic diversification. China, being geographically proximate, economically dynamic, and normatively acceptable, became the natural partner for many

\footnotetext{
${ }^{39}$ Jonathan Kirshner, American Power After the Financial Crisis (Ithaca: Cornell University Press, 2014)

${ }^{40}$ Charles Recknagel, "China Emerges as the Big Winner in 2009," Radio Free Europe/Radio Liberty, December 35, 2009, http://www.rferl.org/a/China_Emerges_As_The_Big_Winner_In_2009/1913628.html

${ }^{41}$ Marlene Laruelle and Sebastien Peyrouse, Globalizing Central Asia: Geopolitics and the Challenges of Economic Development (New York: M.E. Sharpe, 2013)
} 
Eurasian states. In other words, local states exercised their agency by facilitating China's emergence as a key player in Eurasian regional affairs to balance Russian influence.

The third phase began in 2013 and is ongoing. This phase is currently dominated by the emergence of a more proactive and direct region-building project in Eurasia. In effect, this phase marks a transition from Deng Xiaoping's maxim of "hide your brightness, bide your time, and do some things," to Xi Jinping's efforts to realize the Chinese Dream and the rejuvenation of the Chinese nation. ${ }^{42}$ What makes this phase uniquely distinct is the focus on integrative infrastructure as opposed to concentrating on investments that are purely extractive. Embodied in the "The Silk Road Economic Belt and the $21^{\text {st }}$ Century Maritime Silk Road" initiative, shortened to "Belt Road Initiative," this phase of the regionbuilding project reflects a maturing process in China's Eurasian policy in which the codevelopment of China's western regions and Eurasia is more explicitly linked. As a result, China has emerged as a public goods provider by investing in critical infrastructure that benefits not only itself and the recipient state, but also adjacent states through the promotion of greater inter-regional connectivity. The externalization of its understanding of the security-development nexus effectively signals that China is willing to support geopolitical stability not only through economic development, but also through an ideational alternative. That is, China is offering Eurasian states an alternative normative order, through its development model, in which they do not need to singularly rely on the

\footnotetext{
${ }^{42}$ William A. Callahan, "China's “Asia Dream”: The Belt Road Initiative and the New Regional Order," Asian Journal of Comparative Politics 1(3), 2016, p. 226-243
} 
Western-led "Washington Consensus" in order to develop economically and ensure regime stability. ${ }^{43}$

During this period, China has also sought to build on its initial efforts to develop and enhance its ideational power in Eurasia. As part of his announcement of BRI, Xi Jinping promised to establish a "10-year central government plan to provide 30,000 government scholarships to Shanghai Cooperation Organization member states, and to invite 10,000 teachers and students from these countries' Confucius Institutes to China for study tours. ${ }^{94}$ Furthermore, during a visit to Cairo in 2016 Xi promised an additional 10,000 scholarships and 10,000 training opportunities for Arab countries. ${ }^{45}$

There is indication that this policy is already having measurable effect. According to reports, the education ministry has stated that "the number of international students in China from One Belt, One Road countries like India, Pakistan and Kazakhstan saw an increase of over 10\% in 2015 from a year earlier, which is the largest increase among the top 15 countries that sent students to China." ${ }^{\text {46 }}$ Additionally, Tian Xuejun, China's Vice Minister of Education, revealed that the 53 Confucius Institutes founded in BRI-participant countries are currently teaching Mandarin classes to over 460,000 students, making Mandarin an important second language in these countries, but also a critical component

\footnotetext{
${ }^{43}$ Ibid.

${ }^{44}$ Jiao Wu, and Yunbi Zhang, "Xi Proposes a "New Silk Road' with Central Asia," China Daily, September 8, 2013, http://usa.chinadaily.com.cn/china/2013-09/08/content_16952304.htm

45 "China to Provide Tens of Thousands of Scholarships, Training Opportunities for Arab Nations: Xi," Xinhua News, January 21, 2016, http://news.xinhuanet.com/english/2016-01/21/c_135033115.htm

${ }^{46}$ Wanxia Lin, "Silk Road Scholarships to Expand China's Links to Eurasia," Asia Times, November 28, 2016, http://www.atimes.com/article/silk-road-scholarships-expand-chinas-links-eurasia/
} 
of China's efforts to increase its ideational power abroad. ${ }^{47}$ Furthermore, this phase also marks a period in which Chinese officials have become increasingly willing to promote the effectiveness of their developmental and governance model as a blueprint for other developing countries, something that, along with Mandarin language, has become increasingly appealing as China demonstrates its ability to deliver economic development to its population as well as its neighbors. In other words, Eurasia has provided China a fertile environment in which to develop and promote its ideational power.

In this phase China emerged not only as a pivotal regional actor, but also the force behind the region's transformation. Again, many factors facilitated this process. First, China's geopolitical tensions in East Asia have motivated many influential figures in China to conclude that a western development strategy was necessary in order to achieve strategic diversification. ${ }^{48}$ Historical patterns also galvanized domestic imperatives for the creation of a western development strategy, particularly the fact that Xinjiang has been a historically costly region to maintain for Chinese central authorities. ${ }^{49}$ Another domestic concern revolved around industrial overcapacity, as a result, infrastructure projects in Eurasia became a natural place to offload this overcapacity while simultaneously benefiting the

\footnotetext{
${ }^{47}$ Cal Wong, "One Belt, One Road, One Language?” The Diplomat, May 12, 2017, http://thediplomat.com/2017/05/one-belt-one-road-one-language/

${ }^{48}$ See: Yazhou Liu, "On Advance Toward the West," 2010, http://www3.nd.edu/ pmoody/Text\%20Pages\%20-\%20Peter\%20Moody\%20Webpage/Liu\%20Yazhou.htm ; Jisi Wang, "March West: Rebalancing China’s Geopolitical Strategy," Global Times, 2012, http://opinion.huanqiu.com/opinion_world/2012-10/3193760.html; Yun Sun, "Westward Ho!: As America Pivots East, China Marches in the other Direction," Foreign Policy, February 7, 2013, http://foreignpolicy.com/2013/02/07/westward-ho-2/

${ }^{49}$ Thierry Kellner, "China: The Uighur Situation from Independence for the Central Asian Republics to the Post 11 September Era," refworld, 2002, p. 8, http://www.refworld.org/docid/465e8a292.html
} 
overall strategy of integrating the region for the purposes of economic development and stability. ${ }^{50}$ At the same time, Russia's annexation of Crimea led to key economic sanctions, thus forcing Moscow rely on Beijing as its main political and economic partner. ${ }^{51}$ This meant that despite Russian reservations about China's growing role in Eurasia, it could not afford to overtly undermine Beijing. ${ }^{52}$ Furthermore, Russia's actions in Georgia, and later Crimea, have concerned many of the states in the region, ${ }^{53}$ particularly since a number of these states still possess a sizeable minority of ethnic Russians. These events continued to make China a natural partner, thus, local states continued to facilitate China's emergence as a pivotal player in Eurasian affairs.

\section{$\underline{\text { Regional Transformation }}$}

These three phases of China's region-building project illustrate how it has played a role in the transformation of Eurasia and reveal a vision of regional formation and transformation with three principal characteristics. First, China's Eurasian region-building project emerges from domestic state-building efforts. Since China's domestic state-

\footnotetext{
${ }^{50}$ Junhua Zhang, "What's Driving China's One Belt, One Road Initiative?, East Asia Forum, September 2, 2016, http://www.eastasiaforum.org/2016/09/02/whats-driving-chinas-one-belt-one-road-initiative/

${ }^{51}$ Alexander Gabuev, "Friends with Benefits? Russian-Chinese Relations After the Ukrainian Crisis," Carnegie Moscow Center, June 29, 2016, http://carnegie.ru/2016/06/29/friends-with-benefits-russianchinese-relations-after-ukraine-crisis-pub-63953

${ }^{52}$ Ibid.

${ }^{53}$ See: Birgit Brauer, "Crisis in Crimea: Will Kazakhstan be Next? Eurasia Daily Monitor 11(48), March 13, 2014, https://jamestown.org/program/crisis-in-crimea-will-kazakhstan-be-next/; "Statement by the Ministry of Foreign Affairs of the Republic of Kazakhstan on the Situation on Southeastern Ukraine," Kazinform, March 3, 2014, http://www.inform.kz/en/statement-of-the-foreign-ministry-of-the-republic-ofkazakhstan-on-the-situation-in-ukraine_a2635749; "Statement of the Information Agency "Jahon" on the Events in Ukraine," Ministry of Foreign Affairs of the Republic of Uzbekistan, March 4, 2014, http://www.mfa.uz/en/press/statements/2014/03/6329/
} 
building efforts are underpinned by a security-nexus logic in which the state plays a central role in the provision of security and development, its corresponding region-building project shares the same logic. In addition to narratives about security and development, China's region-building project is promoted through the establishment of the historicity of China's engagement in Eurasian affairs and its support for non-interference norms. As a result, these projects are not geared towards the creation of supranational entities like the EU, rather, they aim to increase state capacity in order to facilitate state control of its territory and provide the conditions for development. Lastly, because the physical formation and transformation of Eurasia have been the result of China's investment in infrastructural interconnectivity and co-development, it is evident that Beijing is situating itself at the center of its Eurasian region-building project.

China's Eurasian region-building project has thus far galvanized the beginning of a region-wide geopolitical, economic, and potentially, an ideational, eastward reorientation. This is paving the way for China's emergence as dominant power in the region. While Russia remains an important political actor in the former Soviet space, this influence is eroding as a result of its underperforming economy, the reduced numbers of ethnic Russians and Russian language speakers, as well as its tendency, since the collapse of the USSR, to interfere in the internal and external affairs of CIS members. The U.S. and the E.U., two actors that have at different times shown keen interest in Eurasia, have also encountered a number of challenges. For example, both entities have often attached liberalnormative conditions to aid and investment packages. Furthermore, American geographical distance and European financial constraints demonstrate a limit to their ability to challenge Russia, much less China, in what is effectively their backyard. In contrast, 
China's emergence as a key player in Eurasian affairs is largely due to its ability to socialize the region into mutually beneficial political arrangements, its massive investment commitments, its ability to deliver political and economic diversification for many states, and finally, its policy of non-interference.

By effecting this regional reorientation, China is transforming the region. The adage that "all roads lead to Rome" is becoming a real possibility for the PRC as roads begin to lead towards China. This is something that has important long-term geopolitical, economic, and ideational implications for the region, especially in the context of China's reemergence as a global power. In the short and mid-term, China can successfully accomplish its state-building initiatives. For example, this regional transformation can help China's efforts to diversify its energy mix and energy supply sources. This is directly correlated to China's desire to achieve strategic diversification as well as secure energy and trade routes that are not dominated by the U.S. Navy. Furthermore, the integration of Eurasian markets into Xinjiang and other western provinces is likely to deliver greater levels of economic development to China's western region and to Eurasia's Center. The land-locked Central Asian republics will be able to diversify their markets beyond Russia, and even China, once BRI infrastructure projects reach completion. It will also allow countries like Iran and Pakistan to benefit from physical and economic integration efforts since the initiative expands their market connectivity. In addition, their strategic geographic position will allow them to reap the benefits of transit revenue. More importantly, however, it allows China to more effectively exercise control of its western provinces, particularly Xinjiang. 


\section{Organization of the Study}

The following chapter sets the foundation of this study through the discussion of a number of critical literatures regarding regions, regionalism, regionalization, and regionness. It is presented in a chronological manner so as to illustrate the origins of the sub-field of regional studies in international relations, and how it has developed. Of particular importance is how regions are conceptualized, especially how they form and transform. There are three broad literatures that are engaged: (1) the integration theories of functionalism, neo-functionalism, federalism, and inter-governmentalism, labeled "old regionalism" by proponents of "new regionalism"; (2) the linkage of security and regions in security communities and security complexes; (3) and the social and critical perspectives provided by the "new regionalism approach" and the region-building approach.

The social and critical perspectives offered by the "new regionalism" literature provide important insights into the social construction of regions by assessing how major power interests shape a region, as well as how co-constitutive dynamics form regional cohesion. In other words, it provides the understanding that regions are not naturally given, rather, regions are what states make of them. ${ }^{54}$ The region-building approach also contributes to this understanding of regions by focusing on the role of the region-builders and their narratives. A framework utilizing components of these approaches will be used for the study in order to demonstrate how region-building projects can emerge from domestic state-building efforts and consequently, how this process can geopolitically, economically, and ideationally transform regions. Doing this requires tracing the trajectory

\footnotetext{
${ }^{54}$ See: Louise Fawcett, "Exploring Regional Domains: A Comparative History of Regionalism," International Affairs 80(3), 2004, p. 434; Nadine Godehardt, The Chinese Constitution of Central Asia: Regions and Intertwined actors in International Relations (New York: Palgrave MacMillan, 2014), p. 71
} 
from domestic needs to foreign policy, and its consequent effects. Consequently, this allows for a more effective understanding of how China plays a pivotal role as a regionbuilder in Eurasia through its narratives and actions.

Following the literature review of Chapter 1, Chapter 2 evaluates a key statebuilding effort, Xinjiang's Double-Opening strategy, and how it played a key role in China's engagement with the USSR and its subsequent collapse. It is contended that the Double Opening strategy required a region-building project in order to achieve success, thus moving China towards greater engagement with Eurasian countries. This is considered the first phase of China's Eurasian foreign policy. Chapter 3 covers the second phase and focuses on the Great Western Development strategy, another state-building effort aimed at closing domestic development gaps in which Xinjiang played a pivotal role. It is argued that during this phase China sought to consolidate gains made through the Double-Opening strategy as well as its region-building project by further integrating Xinjiang and institutionalizing the informal summits of the Shanghai Five through the Shanghai Cooperation Organization. This allowed China to exercise greater control of the province. Chapter 4 addresses the third and current phase and focuses on the Belt Road Initiative, a national state-building effort that aims to realize the Chinese Dream of National Rejuvenation in which, yet again, Xinjiang plays a pivotal role. This phase represents a shift in Chinese policy which is reflected in a more explicit linkage between domestic development and regional development.

Lastly, the conclusion addresses how these three state-building efforts generated accompanying region-building projects as well as the underlying logic that underpinned them. Furthermore, the conclusion assesses how these projects have resulted in the 
geopolitical, economic, and ideational transformation of Eurasia. This chapter also evaluates the general trends that have emerged as a result of China's policy. It concludes that China's Eurasian foreign policy is paving the way for the re-connection of the Eurasian sub-regions in which China plays a dominant role and can develop its normative power through the promotion of Mandarin and the export of its development model. It is contended that as a result, China is better positioned to establish regional dominance in Eurasia rather than, as is commonly assumed, in East Asia. 


\section{Chapter 1: Of Regions, Regionalism, Regionalization, and Region-Building}

The purpose of this study is to assess how domestic narratives generate regionbuilding projects and help validate the empirical process of their formation and transformation. This requires an understanding of what a region is, but more importantly, an understanding of the context and the political processes that generate these projects and their consequent effects. In other words, it is also necessary to understand regionalism and regionalization as a function of politics and as a foundation of region-building. Attempting to understand regions as analytical units, however, reveals an immediate challenge: there is "little consensus" on its basic definition. ${ }^{55}$ Definitions have ranged from broad conceptions focused on geographical proximity and mutual interdependence, ${ }^{56}$ to narrower ones that conceptualize regions as a group of "states which have some common ethnic, linguistic, cultural, social, and historical bonds." 57 As Andrew Hurrell indicates, regions have been differentiated through a number of diverse variables. For example, they have been defined by their social cohesiveness, measured by variables such as ethnicity, race, language, religion, culture, history, or even a consciousness of common heritage; economic cohesiveness, measured by trade patterns and economic complementarity; or,

\footnotetext{
55 William R. Thompson, “The Regional Sub-system: A Conceptual Explication and a Propositional Inventory,” International Studies Quarterly 17(1), 1973, p. 92

56 Josef S. Nye, Peace in Parts: Integration and Conflict in Regional Organization (Boston: Little, Brown \& Company, 1971), p. 7-8

${ }^{57}$ Louis J. Cantori and Steven L. Spiegel, International Politics of Regions: A Comparative Approach (Englewood Cliffs: Prentice Hall, 1970), p. 12
} 
organizational cohesiveness, measured by the presence of formal institutions. ${ }^{58}$ In other words, the definition of what constitutes a region is largely dependent on what is being investigated by any given researcher, institution, or state. Furthermore, by extension, the geographical parameters of a region are also contingent on this process.

This understanding of regions implies that they are not naturally given. Rather, they are constituted through actors. As Hurrell first argued, "all regions are socially constructed and politically contested. ${ }^{59}$ Other scholars have since made similar arguments. For example, Louise Fawcett has contended that "regions and regionalism are what states and non-state actors make of them," 60 while Nadine Godehardt has stated that regions "portray what actors are making of them." ${ }^{61}$ Collectively, these lines of reason echo the thesis posed by Alexander Wendt in the context of anarchy in international relations. ${ }^{62}$ To this literature, contributions by Martin W. Lewis and Karen E. Wigen, as well as Karoline Postel-Vinay, add the importance of historical developments and the political criteria used for the demarcation of regions based on those developments. ${ }^{63}$ Consequently, it is evident that the

\footnotetext{
58 Andrew Hurrell, "Regionalism in theoretical perspective," in Regionalism in World Politics: Regional Organization and International Order, eds. Louise Fawcett \& Andrew Hurrell (Oxford: Oxford University Press, 1995), p. 38

${ }^{59}$ Ibid.

${ }^{60}$ Louise Fawcett, "Exploring Regional Domains: A Comparative History of Regionalism," International Affairs 80(3), 2004, p. 434

${ }^{61}$ Nadine Godehardt, The Chinese Constitution of Central Asia: Regions and Intertwined actors in International Relations (New York: Palgrave MacMillan, 2014), p. 71

${ }^{62}$ Alexander Wendt, "Anarchy is What States Make of It: The Social Construction of Power Politics," International Organization 46(2), 1992, p. 391-425

${ }^{63}$ See: Martin W. Lewis and Karen E. Wigen, The Myth of Continents: A Critique of Meta Geography (Berkeley: University of California Press, 1997); Karoline Postel-Vinay, "The Historicity of the International Region: Revisiting the "Europe and the Rest" Divide," Geopolitics 12(4), 2007, p. 555-569
} 
definition of what constitutes a region can only be assessed through the acts of the actors defining it. This not only makes the definition of regions continuously contested, as Hurrell indicates, it effectively makes them historically contingent. ${ }^{64}$ As a result, the role of the constituting actor is critical for the understanding of regions, in addition to the process that leads to their formation and transformation. ${ }^{65}$ In order to comprehend this process, an understanding of regionalism and regionalization is necessary.

\section{$\underline{\text { Regionalism, Regionalization, and Regionness }}$}

Regionalism can refer to the phenomenon of regional integration, but also to the ideology that promotes it. ${ }^{66}$ As a result, the term has been used in a myriad of ways in the literature. However, in its broadest interpretation, regionalism refers to a "tendency and a political commitment to organize the world in terms of regions; more narrowly, the concept refers to a specific regional project." ${ }^{, 67}$ Regionalism differs from regionalization, in the sense that the latter refers to the "complex process of forming regions." 68

The study of regionalism has experienced two waves of scholarship. The first of these waves was dominated by the integrationist theories of federalism, functionalism, neo-

\footnotetext{
64 Ibid.

${ }^{65}$ See: Iver B. Neumann, “A Region-Building Approach to Northern Europe,” Review of International Studies 20(1), 1994, p. 53-74; Iver B. Neumann, “A Region-Building Approach," in Theories of New Regionalism: A Palgrave Reader, eds. Fredrik Soderbaum and Timothy M. Shaw (New York: Palgrave MacMillan, 2003), p. 160-178; Karoline Postel-Vinay, "The Historicity of the International Region: Revisiting the "Europe and the Rest" Divide," Geopolitics 12(4), 2007, p. 555-569

${ }^{66}$ Bjorn Hettne and Fredrik Soderbaum, “The New Regionalism Approach,” Politeia 17(3), 1998, p. 5

${ }^{67}$ Bjorn Hettne, “Beyond 'New' Regionalism,” New Political Economy 10(4), 2005, p. 545

68 Ibid.
} 
functionalism, and inter-governmentalism. These contributions are collectively labeled as "Old Regionalism" by second-wave scholars who proposed a new research agenda under the term "New Regionalism Approach" (NRA). The second wave of regionalism introduces new concepts like regionalization and regionness and adopts a more pluralistic approach to the study of regions. The NRA also focuses on a wider range of actors engaged in the process of regionalism. As a result, the contributions made by social constructivists and critical theorists have come to dominate the NRA scholarship. In parallel to the "old" and "new" regionalism approaches, there have also been a number of contributions that primarily focused on the security dimensions of regionalism. These contributions introduced the concepts of security communities and complexes that have, to varying degrees, been incorporated by scholars in both waves.

\section{"Old" Regionalism}

\section{Federalism and Functionalism}

Debates centered on regionalism, and particularly, regional integration, occurred in the context of $20^{\text {th }}$ century European conflicts that resulted in two major world wars. Consequently, the central preoccupation of these initial contributions was the role of the state in conflict and the normative desire to erode the centrality of the state in order to foster peace. ${ }^{69}$ From this initial debate two competing approaches emerged: federalism and functionalism. Of these two, only the former was specifically focused on regional-level integration, the latter was, by design, meant to be systemically applied. Nevertheless, the

\footnotetext{
${ }^{69}$ Ben Rosamond, Theories of European Integration (New York: Palgrave MacMillan, 2000)
} 
two approaches were inspired by the same events and generally shared a negative view of the nation-state. More importantly, however, as will be discussed below, they served as the earliest foundation of theories about regions.

For proponents of federalism in Europe, the disillusionment with the state, and the nationalism it engendered, not only caused conflict, but also rendered states incapable of meeting the needs of their citizens. Altiero Spinelli, an Italian federalist, argued that "nation states [had] lost their property rights since they cannot guarantee the political and economic safety of their citizens." ${ }^{70}$ Spinelli contended that the wars, and the destruction they caused, provided the ripe environment for the creation of a "federal regime, which [would] place an end to the current anarchy."71 Michael Burgess illustrates this sentiment among other European elites and intellectuals by asserting that the experience of the Second World War, as well as the threat of a future war, served as the primary catalyst for federalist sentiment in Europe post-1945. ${ }^{72}$

Accordingly, federalists called for the creation of a European federation. While federalism can mean "different things to different people in different contexts at different times," $" 73$ within the context of the European Union it refers to the application of federal

\footnotetext{
${ }^{70}$ Altiero Spinelli, The European Adventure: Tasks for the Enlarged Community, translated by G. Lovett (Knight (Charles) \& Co. Ltd., 1972), p. 68

71 Altiero Spinelli, “The Ventone Manifesto," translated by E. Urgesi, 1944, http://www.altierospinelli.org/manifesto/en/pdf/manifesto1944en.pdf

72 Michael Burgess, Federalism and European Union: Political Idea, Influences and Strategies in the European Community, 1972-1987 (New York: Routledge, 1991), p. 17

${ }^{73}$ Michael Burgess, "Federalism," in European Integration Theory $2^{\text {nd }}$ Edition, eds. Antje Wiener and Thomas Diez (Oxford, Oxford University Press, 2009), p. 25
} 
principles to the process of European integration. ${ }^{74}$ In essence, it is based on the idea of a voluntary union of states and peoples. Since the purpose of the EU is regional integration as opposed to assimilation, the federal principle of self-rule and shared-rule are central to the process. Consequently, the process remains anti-absolutist and anti-centralist through the preservation of autonomy, solidarity, pluralism, citizenship, and particularly, subsidiarity. ${ }^{75}$ The principle of subsidiarity allows for the basic social functions to be "carried out at primary or lower levels of associational life with performance criteria determining which functions should be managed at a higher level." ${ }^{\prime 76}$ For all purposes intended, the European integration process adopted this form of governance as integration deepened through the decades after the creation of the European Economic Community (EEC) in 1957.

In contrast to the federalist approach is functionalism. Functionalism has come to be associated almost entirely with a single scholar: David Mitrany. ${ }^{77}$ While Mitrany shared the same concern that federalists had regarding the experience of two world wars and the threat of future ones, as well as their skepticism of the nation-state, he remained highly critical of federalism as a tool for regional integration. ${ }^{78}$ From Mitrany’s perspective, European federalism was merely supplanting one form of nationalism with another. He

\footnotetext{
${ }^{74}$ Ibid. p. 30

${ }^{75}$ Ibid.

${ }^{76}$ Michael Burgess, Federalism and European Union: The Building of Europe, 1950-2000 (New York: Routledge, 2000), p. 15

${ }^{77}$ Bjorn Hettne, “Beyond 'New' Regionalism,” New Political Economy 10(4), 2005, p. 546

${ }^{78}$ David Mitrany, "The Prospect of Integration: Federal or Functional," Journal of Common Market Studies 4(1), 1965, p. 124
} 
contended that the argument for a federation in the name of peace, as Robert Schuman and Jean Monnet, two key proponents of European federalism, were making, had been made by other nationalists like Giuseppe Mazzini in the name of national unification. ${ }^{79}$ For Mitrany, the prospect of two powerful federations facing each other in Europe, or even on the international stage, was not a step in the right direction and would not address the pressing issue of increasing political divisions in the world. Thus, he concluded a federation would only "change the dimensions of nationalism, not its nature." 80

In lieu of federalism, Mitrany offered functionalism. Functionalism is an approach to peace-building through international integration. International integration would be characterized by the collective governance and the material interdependence between states. ${ }^{81}$ This integration would occur through cooperation along lines of common interests. More specifically, areas that met the basic functional needs of societies such as transportation, trade, production, and welfare. ${ }^{82}$ Functionalism reflects Mitrany’s concern about political division; as a result, the political dimension of cooperation is largely replaced with the technical. Mitrany claimed that functional neutrality was possible, whereas political neutrality was not. ${ }^{83}$ Thus, it was possible for European countries to

\footnotetext{
${ }^{79}$ Ibid.

${ }^{80}$ David Mitrany, "The Functional Approach to World Organization," International Affairs 24(3), 1948, p. 352

${ }^{81}$ David Mitrany, The Progress of International Government (London: G. Allen \& Unwin, 1933), p. 101

${ }^{82}$ See: David Mitrany, “The Functional Approach to World Organization," International Affairs 24(3), 1948, p. 350-363; David Mitrany, A Working Peace System (Chicago: Quadrangle Books, 1966)

${ }^{83}$ David Mitrany, "The Functional Approach to World Organization," International Affairs 24(3), 1948, p. 358
} 
cooperate on areas like transportation, a functional area, with the USSR, whereas a European Federation, a political unit, would find it more difficult to do so. This was possible because functional arrangements possessed the virtue of technical selfdetermination. In other words, the nature of each function delineates the "scope and powers needed for its effective performance." ${ }^{84}$ As a result, functionalism, through its gradual process of international integration not only eroded the sovereignty of the state, but by design, envisioned a de-territorialized international system. This approach would be challenged, particularly for its omission of politics from cooperation mechanisms, by Ernst B. Haas through his neo-functionalist approach.

\section{Neo-Functionalism}

As its name suggests, neo-functionalism shares some of the core assumptions of functionalism such as the emphasis on "technocratic decision-making, incremental change, and learning process." 85 However, it departs from functionalism in a number of important ways. The first of these is that while functionalists like Mitrany contended that technical self-determination delineated the form, scope, and purpose of an organization, neofunctionalists like Ernst B. Haas contended that the autonomous influence of supranational institutions and organized interests held significant influence in setting those parameters. ${ }^{86}$

\footnotetext{
${ }^{84}$ Ibid.

85 Arne Nienmann and Philippe C. Schmitter, "Neofuntionalism," in European Integration Theory $2^{\text {nd }}$ Edition, eds. Antje Wiener and Thomas Diez (Oxford, Oxford University Press, 2009), p. 45-46

${ }^{86}$ Ibid. p. 46
} 
Additionally, while the former envisioned a de-territorialized basis for international integration, the latter was primarily focused on regional integration. ${ }^{87}$ In fact, neofunctionalism shared similarities with the European federalists like Jean Monnet. However, while federalism is strictly a normative political $\operatorname{program}^{88}$ as opposed to a theory, neofunctionalism is intended to be a theory of integration. ${ }^{89}$

For neo-functionalists, integration is a process which, over time, develops its own dynamic. An important component of the neo-functionalist approach to integration is that the process incorporates actors beyond the state. Thus, it opens the possibilities for actors outside of the political domain to play a role in the integration process. ${ }^{90}$ Nevertheless, these actors primarily emerge from the elite class in Europe; Haas primarily focused on non-governmental elites, ${ }^{91}$ while his contemporary neo-functionalist, Leon N. Lindberg, focused on governmental elites. ${ }^{92}$

\footnotetext{
${ }^{87}$ Ibid.

${ }^{88}$ Bjorn Hettne, “Beyond 'New' Regionalism,” New Political Economy 10(4), 2005, p. 546

${ }^{89}$ See: Ernst B. Haas, "International Integration: The European and Universal Process," International Organization 15(3), 1961, p. 366-392; Ernst B. Haas and Philippe C. Schmitter, "Economic and Differential Patterns of Political Integration: Projections About Unity in Latin America," International Organization 18(4), 1964, p. 705-737

${ }^{90}$ Ernst B. Haas, "Technocracy, Pluralism, and the New Europe," in A New Europe?, ed. Stephen Richards Graubard (Boston: Houghton Mifflin, 1964), p. 62-88

${ }^{91}$ Ernst B. Haas, The Uniting of Europe: Political, Social, and Economic Forces 1950-1957 (Stanford: Stanford University Press, 1958)

${ }^{92}$ Leon N. Lindberg, The Political Dynamics of European Economic Integration (Stanford: Stanford University Press, 1963)
} 
As a theory of integration, neo-functionalism assumes that actors are rational and self-interested. ${ }^{93}$ These actors learn about the prospective benefits of regional integration through their interactions through the integration process. ${ }^{94}$ Furthermore, the theory contends that creation of institutions ultimately alters the interests of the participant actors. ${ }^{95}$ The creation of institutions is critical for neo-functionalists since, once created, they are assumed to become largely autonomous from their creators. This directly links to the role of elites as actors since once institutions are created, the bureaucracy that operates it will actively pursue greater integrative policies since it expands the power and capacity of their institution. ${ }^{96} \mathrm{~A}$ vital component of neo-functionalism is the assumption that once functional interdependency between the productive sectors of national economies occurs, a need for greater integration emerges. ${ }^{97}$ This not only reveals the evolutionary nature of the theory, but also automaticity behind one of its core concepts: spillover.

For Haas, spillover describes the process by which the integration of one sector inevitably creates pressure to integrate other sectors. ${ }^{98}$ In the study of the emergence of the European Coal and Steel Community (ECSC), Haas observed how the integration of the

\footnotetext{
${ }^{93}$ Ernst B. Haas, "The Study of Regional Integration: Reflections on the Joy and Anguish of Pretheorizing," International Organization 24(4), 1970, p. 627

${ }^{94}$ Ernst B. Haas, The Uniting of Europe: Political, Social, and Economic Forces 1950-1957 (Stanford: Stanford University Press, 1958), p. 291

${ }^{95}$ Ibid. p. 9-10

${ }^{96}$ Ibid.

${ }^{97}$ Ibid. p. 372

${ }^{98}$ Ibid. p. 383
} 
coal and steel sectors necessitated the integration of other sectors, such as transportation, in order for the ECSC to perform its task and function effectively. ${ }^{99}$ Lindberg came to the same conclusion in his study of the European Economic Community. ${ }^{100}$ In later works, this understanding of spillover would be refined as "functional spillover" in order to differentiate it from other forms of spillover within the neo-functionalist literature. ${ }^{101}$

As previously mentioned, both Haas and Lindberg studied the role of elites in the process of integration, although they focused on two different groups of this demographic. In addition to this difference, however, the two also diverged on how these elites influenced the integration process. For Haas, the key demographic were non-governmental elites such as business and professional associations, trade unions, and other interest groups that could directly benefit from greater integration. ${ }^{102}$ According to Haas, the integration of a sector would link domestic interest groups with the new institutions. If this integration led to benefits, these interest groups would then support greater integration. ${ }^{103}$ Lindberg, however, having focused on governmental elites, attributed greater integration to the effects of socialization. ${ }^{104} \mathrm{He}$ contended that the numerous EU working groups had given

\footnotetext{
99 Ibid.

${ }^{100}$ Leon N. Lindberg, The Political Dynamics of European Economic Integration (Stanford: Stanford University Press, 1963)

${ }^{101}$ Leon N. Lindberg and Stuart A. Scheingold, Europe's Would-be Polity: Patterns of Change in the European Community (Englewood Cliffs: Prentice Hall, 1970)

102 Ernst B. Haas, The Uniting of Europe: Political, Social, and Economic Forces 1950-1957 (Stanford: Stanford University Press, 1958), p. 312-313

103 Ibid.

${ }^{104}$ Leon N. Lindberg, The Political Dynamics of European Economic Integration (Stanford: Stanford University Press, 1963)
} 
rise to greater levels of interactions between the civil servants representing their respective states. As a result of these interactions, these elites would be socialized within the framework of these working groups. ${ }^{105}$ The implied conclusion of this socialization process was that through consensus-building politics between these civil servants, a greater drive for integration would be fostered. ${ }^{106}$ Despite these important differences, the pressures exerted by governmental and non-governmental elites on the integration process were later termed "political spillover" by Jeppe Tranholm-Mikkelsen. ${ }^{107}$

A third type spillover that has been identified in neo-functionalism is "cultivated spillover." 108 This type of spillover links elites as well as the institutions that are created to support integration. In essence, the institutions, in this case the European Commission (EC), serves as a facilitator of the integration processes. According to Haas, the EC was at the forefront of cultivating the logic of functional-economic interdependence. This would expand the scope and capacity of the institution, thus leading to greater integration. ${ }^{109}$ Lindberg, on the other hand, in line with his thesis of socialization, contended that the EC provided the setting for the cultivation of ties between the civil servants representing their

\footnotetext{
${ }^{105}$ Ibid.

${ }^{106}$ See: Leon N. Lindberg, The Political Dynamics of European Economic Integration (Stanford: Stanford University Press, 1963); Leon N. Lindberg and Stuart A. Scheingold, Europe's Would-be Polity: Patterns of Change in the European Community (Englewood Cliffs: Prentice Hall, 1970)

${ }^{107}$ Jeppe Tranholm-Mikkelsen, "Neo-Functionalism: Obstinate or Obsolete? A Reappraisal in Light of the New Dynamism of the EC," Millennium: Journal of International Studies 20(1), 1991, p. 5

${ }^{108}$ Ibid. p. 6

${ }^{109}$ Ernst B. Haas, "Technocracy, Pluralism, and the New Europe," in A New Europe?, ed. Stephen Richards Graubard (Boston: Houghton Mifflin, 1964), p. 62-88
} 
countries. Consequently, the centrality and authority of the EC allowed it to manage not only relations between its participant states, but also the relations between the varying interest groups within each state. ${ }^{110}$

After a period of decline, which will be covered in the following section, neofunctionalism re-emerged in prominence, particularly in the context of European integration, in the 1970s. Contributions by Philippe Schmitter have further refined the theory, particularly to answer one of the main criticisms aimed at it, namely, the automaticity attributed to spillover. Schmitter introduced a typology of seven strategic choices available to an actor of which spillover was only one of the choices. In doing so, Schmitter reintroduced a greater level of agency to the process of integration. These choices included:

1) spillover, i.e., to increase both the scope and level of his commitment concomitantly; 2) spill-around, i.e., to increase only the scope while holding the level of authority constant or within the zone of indifference; 3) buildup, i.e., to agree to increase the decisional autonomy or capacity of joint institutions but deny them entrance into new issue areas; 4) retrench, i.e., to increase the level of joint deliberation but withdraw the institutions(s) from certain areas; 5) muddle-about, i.e., to let the regional bureaucrats debate, suggest, and expostulate on a wider variety of issues but decrease their actual capacity to allocate values; 6) spill-back, i.e., to retreat on both dimensions, possibly returning to the status quo ante initiation; 7) en-capsulate, i.e., to respond to crisis by marginal modifications within the zone of indifference. ${ }^{111}$

In addition to this typology of strategic choices, Schmitter illustrated the endogenous contradictions that emerge in regional integration processes, but also addressed a critique aimed at the theory, specifically, the neglect of exogenous forces on the process of

\footnotetext{
${ }^{110}$ Leon N. Lindberg, The Political Dynamics of European Economic Integration (Stanford: Stanford University Press, 1963), p. 71

111 Philippe C. Schmitter, “A Revised Theory of Regional Integration,” International Organization 24(4), 1970 , p. 846
} 
integration. He demonstrated that exogenous forces did not always present an impediment for regional integration, they can actually facilitate it. ${ }^{112}$ This is an important contribution since early contributions to neo-functionalism had failed to address the issue of foreign policy in the context of an increasingly integrated region. Schmitter contended that once a regional integration project was underway, and its constituent units had developed common policies, "participants will find themselves compelled - regardless of their original intentions - to adopt common policies vis-à-vis non-participant third parties. Members will be forced to hammer out a collective external position (and, in the process, are likely to rely increasingly on the new central institutions to do it)." "113 This process was later added to the typologies of spillover by Arne Niemann who coined the term "exogenous spillover."114

Despite its primacy as a theory of integration in the European context, neofunctionalism was not without its critics. During the 1960s the process of European integration had stagnated and, during the "empty chair crisis," there was a real risk that the entire process had reached its apex. Inter-governmentalism emerged as the main contender to neo-functionalism during this period.

112 Ibid.

113 Philippe C. Schmitter, "Three Neo-Functional Hypotheses about International Integration," International Organization 23(1), 1969, p. 165

114 Arne Niemann, Explaining Decisions in the European Union (Cambridge, Cambridge University Press, 2006), p. 120-121 
Inter-governmentalism

After a period that oversaw the successful integration of the coal and steel sectors, the nuclear sector, and finally, the formation of an economic community that sought the creation of a common market and a customs union, the integrationist movement in Europe began to stagnate in the 1960 s. ${ }^{115}$ This stagnation was primarily due to French politics under the presidency of Charles de Gaulle. In 1963, de Gaulle vetoed Britain's entry into the EEC, proclaiming that "England is not much anymore." 116 The French President repeated his veto in $1967,{ }^{117}$ thus, for a time, halting the geographical expansion of European integration. However, another more critical stalemate occurred in 1965 as a result of de Gaulle's concern over the erosion of French sovereignty due to ongoing negotiations regarding the transfer of some budgetary power to the European Parliament. ${ }^{118}$ This stalemate came to be known as the "empty chair crisis" in which France removed its representative from the Council of Ministers. ${ }^{119}$ It would take a year until this stalemate was resolved through the Luxembourg Compromise which shifted the institutional power of balance in the EEC from the Commission to the Council of Ministers. Additionally, the

\footnotetext{
115 “A Peaceful Europe - The Beginning of Cooperation,” European Union, https://europa.eu/europeanunion/about-eu/history/1945-1959_en

${ }^{116}$ Kathryn Hadley, "Back when Britain was Banging on Europe's Door," The Guardian, October 13, 2012, https://www.theguardian.com/commentisfree/2012/oct/13/britain-europe-david-cameron-eu 
compromise confirmed the right of member states to veto any of the Commission's legislative proposals that interfered with the national interest. ${ }^{120}$ As a result of this compromise, majority voting was made meaningless in the EC, thus undermining integrationist efforts within the EEC for many years. ${ }^{121}$

These events put into question the viability of spillover as a concept, and with it, the theory of neo-functionalism. In fact, its main proponent, Ernst B. Haas, declared by 1975 that regional integration theory was obsolete. ${ }^{122}$ Beyond the inter-neo-functionalist struggle, however, there was a competing approach to regional integration offered by intergovermentalists. Its main proponent, Stanley Hoffman, not only challenged the automaticity of spillovers, but also the role of the supranational institutions that, according to neo-functionalists, played a central role in the integration process. According to Hoffmann, the nation-state remained the main actor in the process of international integration. Thus, it was governments, representing the interests of their respective constituents, that had the power to facilitate or impede the integration process, as de Gaulle had effectively demonstrated in the 1960s. ${ }^{123}$ Furthermore, according to Hoffman, and later

\footnotetext{
${ }^{120}$ See: Ben Rosamond, Theories of European Integration (New York: Palgrave MacMillan, 2000), p. 75; Brigid Laffan and Sonia Mazey, "European Integration: the European Union - Reaching an Equilibrium?" in European Union: Power and Policy-Making $3^{\text {rd }}$ edition, ed. Jeremy Richardson (New York: Routledge, 2006), p. 60

121 Ibid.

122 This position can be found in The Obsolescence of Regional Integration Theory (Berkeley: University of California Press, 1975), although he would later retract this position in the reissue of The Uniting of Europe in 2004.

123 See: Stanley Hoffmann, "The European Process at Atlantic Cross Purposes," Journal of Common Market Studies 3(2), 1964, p. 85-101; Stanley Hoffmann, "Obstinate or Obsolete? The Fate of the NationState and the Case of Western Europe," Daedalus 95(3), 1966, p. 862-915
} 
Alan Milward, another inter-governmentalist, the process of integration strengthens the nation-state since the process only occurs if the state benefits from it. ${ }^{124}$

Hoffmann criticized neo-functionalists for placing too much emphasis on the process of integration as opposed to the context, which obscured the actual dynamics behind European integration. ${ }^{125}$ Additionally, since neo-functionalists were far too focused on inter-European dynamics, they paid little attention to exogenous forces that played a vital role in defining state interests, and thus, their propensity to pursue integration. While Schmitter, as indicated above, attempted to address this shortcoming of neo-functionalism, he came to a different conclusion than Hoffman. The latter contended, that "every international system owes its inner logic and its unfolding to the diversity of domestic determinants, geo-political situations, and outside aims among its units," ${ }^{126}$ thus, "any international system based on fragmentation tends, through the dynamics of unevenness, to reproduce diversity." 127 This "logic of diversity," creates diverse as opposed to convergent interests, and as a result, it limits the "degree to which the "spillover" process can limit the freedom of action of the government." ${ }^{128}$ Using the logic of diversity, Hoffmann sought to explain, both, the progress of European integration, as well as the

\footnotetext{
${ }^{124}$ See: Stanley Hoffmann, "Obstinate or Obsolete? The Fate of the Nation-State and the Case of Western Europe," Daedalus 95(3), 1966, p. 862-915; Alan Milward, The European Rescue of the Nation-State (New York: Routledge, 1992)

${ }^{125}$ Stanley Hoffmann, "The European Process at Atlantic Cross Purposes," Journal of Common Market Studies 3(2), 1964, p. 85

${ }^{126}$ Stanley Hoffmann, "Obstinate or Obsolete? The Fate of the Nation-State and the Case of Western Europe," Daedalus 95(3), 1966, p. 866

${ }^{127}$ Ibid.

${ }^{128}$ Ibid. p. 882
} 
stagnation that afflicted the process in the 1960s. He did this through the separation of low and high politics.

The main purpose for the distinction between low and high politics was to illustrate how the former was an area in which cooperation was more likely, whereas the latter was an area in which states would find little convergence. Low politics was characterized as operating in economic and technocratic areas perceived to be largely uncontroversial, while high politics operated with issues concerning foreign policy and national security. European integration, Hoffmann argued, occurred along the lines of low politics. This phenomenon was later described as "negative integration" by John Pinder. ${ }^{129}$ However, once efforts were made to transfer a measure of sovereignty to supranational entities, the integration process stagnated due to diverging interest. This difference in result is the outcome of two competing logics, that of "logic of integration," which represents neofunctionalism, and Hoffmann's own logic of diversity. According to Hoffmann:

"The logic of integration is that of a blender which crunches the most diverse products,
overcomes their different tastes and perfumes, and replaces them with one, presumably
delicious juice. One lets each item be ground because one expects a finer synthesis: that is,
ambiguity helps rather than hinders because each "ingredient" can hope that its taste will
prevail at the end. The logic of diversity is the opposite: it suggests that, in areas of key
importance to the national interest, nations prefer the certainty, or the self-controlled
uncertainty, of national self-reliance, to the uncontrolled uncertainty of the untested blender;
ambiguity carries one only a part of the way."130 An important component of this conclusion was that the logic of integration heralded by neo-functionalists, was based on the promise of delivering positive sum outcomes on a

\footnotetext{
${ }^{129}$ John Pinder, "Positive Integration and Negative Integration: Some Problems of Economic Union in the EEC," The World Today 24(3), 1968, p. 88-110

${ }^{130}$ Stanley Hoffmann, "Obstinate or Obsolete? The Fate of the Nation-State and the Case of Western Europe," Daedalus 95(3), 1966, p. 882
} 
regular basis. Thus, while some losses might be incurred, over time, it would be expected that states involved in the process would reap greater gains. However, Hoffmann concluded that while this might be possible through economic integration (and it is clear he remains skeptical even on this front), this was not possible in political integration (high politics). ${ }^{131}$

In the face of greater levels of integration witnessed in the EU in the 1980s and 1990s, modifications have been made to the theory to account for these events. Andrew Moravcsik is considered the most prolific contemporary proponent of intergovernmentalism, albeit, modified under the moniker of Liberal Inter-governmentalism. Moravcsik maintains that states continue to be the primary actor in the integration process, thus, even as political integration occurs, policymakers protect their countries against future erosion of sovereignty by demanding the unanimous consent of regime members on any sovereignty-related reforms. ${ }^{132}$ Additionally, states will avoid "granting open-ended authority to central institutions that might infringe on their sovereignty, preferring instead to work through intergovernmental institutions such as the Council of Ministers, rather than through supranational bodies such as the Commission and Parliament." 133 Therefore, for Moravcsik, the European Community should be seen as an international regime for policy coordination, whose development can be "explained through the sequential analysis of national preference formation and intergovernmental strategic interaction." ${ }^{134}$ The key

\footnotetext{
131 Ibid.

${ }^{132}$ Andrew Moravcsik, "Negotiating the Single European Act: National Interests and Conventional Statecraft in the European Community," International Organization 45(1), 1991, p. 27

133 Ibid.

${ }^{134}$ Andrew Moravcsik, "Preferences and Power in the European Community: A Liberal Intergovernmentalist Approach," Journal of Common Market Studies 31(4), 1993, p. 480
} 
difference between classical and liberal inter-governmentalism lies in the latter's incorporation of a liberal model of preference formation, ${ }^{135}$ while the former conceptualizes national interest from the context of a state's perception of its relative systemic position.

Both neo-functionalism, and the two variants of inter-governmentalism, despite claims of being "grand theories," have been primarily focused on explaining European integration rather than being systematically applied to other regions of the world. Part of the reason for this is that regional integration, as conceived by these theories, could only be legitimately applied to a single case study: Europe. Furthermore, while it provided a basis for studying regional integration processes, neo-functionalism relied heavily on the influence of supranational institutions which makes it unable to effectively address the competing interests of states that may stall or undermine the process. And while intergovernmentalism and liberal inter-governmentalism may be capable of addressing this shortcoming of neo-functionalism, they inadequately engage the political processes that generate those interests. Lastly, neither approach, nor their variants, have much to say about security as a variable for studying regions despite the fact that the emergence of these theories was the result of European integration, which was in many regards, the product of the experience of two disastrous world wars and the prospect of future wars. This gap in the literature was addressed by scholars who focused on security as a variable for the definition of region as well as the process of integration or disintegration.

\footnotetext{
${ }^{135}$ See: Andrew Moravcsik, "Preferences and Power in the European Community: A Liberal Intergovernmentalist Approach," Journal of Common Market Studies 31(4), 1993, p. 473-524; Andrew Moravcsik, The Choice for Europe: Social Purpose \& State Power from Messina to Maastrich (Ithaca: Cornell University Press, 1998)
} 


\section{$\underline{\text { Security Communities and Complexes }}$}

The concept of security communities emerged in parallel with the aforementioned approaches to integration. Like these other approaches, the development of security communities was influenced by the aftermath of two world wars and the possibility of future wars in the context of an ever-escalating Cold War. Its main proponent, Karl W. Deutsch, argued that the concept was "a contribution to the study of possible ways in which men some day might abolish war."136 Deutsch defined security community as a "group of people which has become 'integrated." 137 In this context, integration referred to the attainment of a "sense of community," as well as institutions and practices, that were strong and widespread enough to foster dependable expectations of "peaceful change" among the population within a territory for a long period of time. Sense of community is an important characteristic of Deutsch's conceptualization of security communities since it alludes to a shared belief by individuals and groups that common social problems could, and should, be solved by processes of peaceful change. Peaceful change referred to the solution of social problems, particularly through institutionalized procedures, without resorting to large-scale physical force. ${ }^{138}$

\footnotetext{
${ }^{136}$ Karl W. Deutsch, Sidney A. Burrell, Robert A. Kann, and Maurice Lee Jr., Political Community and the North Atlantic Area: International Organization in the Light of Historical Experience (Princeton: Princeton University Press, 1957), p. 3

${ }^{137}$ Ibid. p. 5

${ }^{138}$ Ibid.
} 
Developing a sense of community and, thus, paving the way for peaceful change, required "particular habits of political behavior" as well as "particular traditions and institutions." 139 These habits would be acquired by processes of social learning. Consequently, people learn these habits in the "face of background conditions which change only slowly, so that they appear at any moment as something given." ${ }^{140}$ On the surface this appears similar to the socialization process outlined by Lindberg's political spillover. However, it differs greatly in scope as the process illustrated by Deutsch encompasses more than the elite political class since it also includes the masses making up the political units that are integrating. For Deutsch, the sense of community that was relevant for the integration process of security communities was the emergence of a

\footnotetext{
“"we-feeling,' trust, and mutual consideration; of partial identification in terms of selfimages and interests; of mutually successful predictions of behavior, and of cooperative action in accordance with it - in short, a matter of a perpetual dynamic process of mutual attention, communication, perception of needs, and responsiveness in the process of decision-making." 141
}

Without this kind of relationship between the constituent units, Deutsch contended, peaceful change could not be assured. In other words, the political integration that is necessary for security communities, requires a measure of social assimilation between the constituent units. Deutsch focused on the measurement of communication and transaction flows as a means to assess the social assimilation dynamics that drove the political integration process of security communities. By incorporating variables ranging from trade

\footnotetext{
${ }^{139}$ Ibid. p. 37

140 Ibid.

${ }^{141}$ Ibid. p. 36
} 
flows, cultural and student exchanges, migration, tourism, and even mail exchanges, Deutsch's transactional model aimed to evaluate the degree of change, year over year, and therefore, extrapolate whether a given security community was continuing to integrate, stall, or had begun to disintegrate. ${ }^{142}$ However, this methodology was contested. ${ }^{143}$

Deutsch also developed a typology of security communities, specifically differentiating between amalgamated and pluralistic security communities. The former illustrated the formal integration of two or more previously independent units into a single larger unit. This was used to describe the union of the thirteen original American colonies into the United States. The latter, however, differs in that the legal independence of the constituent units remains, such as the relationship between the U.S. and Canada. ${ }^{144}$ In other words, while integration occurs in both of these types of security communities, only in an amalgamated security community is sovereignty entirely transferred to a new, single, entity. As a result, Deutsch concluded that pluralistic security communities are easier to establish and preserve than their amalgamated counterparts. ${ }^{145}$

\footnotetext{
${ }^{142}$ See: Karl W. Deutsch, Sidney A. Burrell, Robert A. Kann, and Maurice Lee Jr., Political Community and the North Atlantic Area: International Organization in the Light of Historical Experience (Princeton: Princeton University Press, 1957); Karl W. Deutsch, "Integration and Arms Control in the European Political Environment: A Summary Report," The American Political Science Review 60(2), 1966, p. 354365

${ }^{143}$ Ronald Inglehart, "Trends and Nontrends in the Western Alliance: A Review," Journal of Conflict Resolution 12(1), 1968, p. 120-128

${ }^{144}$ Karl W. Deutsch, Sidney A. Burrell, Robert A. Kann, and Maurice Lee Jr., Political Community and the North Atlantic Area: International Organization in the Light of Historical Experience (Princeton: Princeton University Press, 1957), p. 6

${ }^{145}$ Ibid. p. 29
} 
The reason for this conclusion is related to the number of conditions necessary to make either of these security communities successful. While Deutsch outlined a dozen conditions that were essential for the success of amalgamated security communities, he contended that only three were important for the formation and maintenance of pluralistic ones. The first of these conditions was the compatibility of major values relevant to political decision-making. The second, was the capacity of the constituent political units to address each other's needs, messages, and actions, quickly, adequately, and without resorting to the use of force. ${ }^{146}$ According to Deutsch, for pluralistic security communities to have this capacity, each unit needed to have established numerous political habits and institutions that favored mutual communication and consultation. ${ }^{147}$ It was important that these habits and institutions were not only capable of receiving the messages from member units, but that they would also be understood and be given real weight in the decisionmaking process. ${ }^{148}$ The third, and last, of these conditions was the mutual predictability of behavior. ${ }^{149}$

Although Deutsch's work was meant to serve as a starting point of a new research agenda aimed at studying the conditions for the emergence of security communities around the globe, ${ }^{150}$ his work went largely unused throughout the Cold War. According to Emanuel Adler and Michael Barnett, the theory of security communities, as proposed by

\footnotetext{
${ }^{146}$ Ibid. p. 66

${ }^{147}$ Ibid.

${ }^{148}$ Ibid. p. 66-67

${ }^{149}$ Ibid. p. 67

${ }^{150}$ Ibid. p. 4
} 
Deutsch, contained a number of conceptual and methodological problems which deterred its usage. Additionally, during this period, scholars appear to have focused on theories of regional integration, like neo-functionalism and inter-governmentalism, as well as international interdependence and international regimes. Lastly, against the backdrop of the Cold War and the prospect of nuclear war, the study of security communities was perceived to be "hopelessly romantic."

\section{Security Communities Revisited}

After decades of relative obscurity, the concept of security communities was revitalized by the work of Emanuel Adler and Michael Barnett. ${ }^{152}$ The renewed focus on security communities emanated from the end of the Cold War and the Constructivist turn in international relations theory that accompanied it. This theoretical turn opened the door for research that explored the role of norms and identity, as well as the social basis for global politics. ${ }^{153}$ In their treatment of security communities, Adler and Barnett sought to

\footnotetext{
${ }^{151}$ Emanuel Adler and Michael Barnett, "Security Communities in Theoretical Perspective," in Security Communities, eds. Emanuel Adler and Michael Barnett (Cambridge: Cambridge University Press, 1998), p. 9

${ }^{152}$ See: Emanuel Adler and Michael Barnett, "Governing Anarchy: A Research Agenda for the Study of Security Communities," Ethics and International Affairs 10, 1996, p. 63-94; Emanuel Adler, "Imagined (Security) Communities: Cognitive Regions in International Relations," Millennium: Journal of International Relations 26(2), 1997, p. 249-277; Emanuel Adler and Michael Barnett, Security Communities (Cambridge: Cambridge University Press, 1998)

${ }^{153}$ Emanuel Adler, Michael Barnett, "Security Communities in Theoretical Perspective," in Security Communities, eds. Emanuel Adler and Michael Barnett (Cambridge: Cambridge University Press, 1998), p. 9
} 
overcome some of the conceptual and methodological shortcomings found in Deutsch's original work. In particular, they sought to move away from Deutsch's transactional model which was heavily quantitative and, instead, focused on the social processes that generated, or were generated by, the transactions that were so central to his work. ${ }^{154}$ Additionally, Adler and Barnett, as well as other scholars who adopted the concept in their research, opted to concentrate on pluralistic as opposed to amalgamated security communities, because, they argued, this form of security community was more closely reflective of international developments in the post-Cold War era. ${ }^{155}$

Adler and Barnett defined pluralistic security community as a "transactional region comprised of sovereign states whose people maintain dependable expectations of peaceful change." 156 These security communities, Adler contends, are "socially constructed 'cognitive regions' or 'community-regions' whose people imagine that, with respect to their security and economic well-being, borders run, more or less, where shared understandings and common identities end." ${ }^{" 157}$ According to Adler, security communities are "socially constructed because shared meanings, constituted by interaction, engender

\footnotetext{
${ }^{154}$ Ibid. p. 8-9

${ }^{155}$ Ibid. p. 5

${ }^{156}$ Emanuel Adler and Michael Barnett, "Governing Anarchy: A Research Agenda for the Study of Security Communities," Ethics and International Affairs 10, 1996, p. 73

${ }^{157}$ Emanuel Adler, "Imagined (Security) Communities: Cognitive Regions in International Relations," Millennium: Journal of International Relations 26(2), 1997, p. 250
} 
collective identities." ${ }^{158}$ As a result, "they are dependent on communication, discourse, and interpretation, as well as on material environments."159

This understanding of security communities makes two further refinements to Deutsch's work. The first is that rather than being principally bound by a sense of "wefeeling' as Deutsch theorized, Adler argues that it is intersubjective knowledge and shared identities that bind these communities. ${ }^{160}$ The second is that by conceptualizing security communities as socially constructed, cognitive regions, Adler is deterritorializing the concept. In other words, while Deutsch demarcated the end and beginning of regions based on geography due to the expectation that proximity would generate common interests deriving from a common culture, economic circumstances, and security concerns, Adler and other scholars using his framework, have removed the variable of geography from the concept. ${ }^{161}$

The concept of peaceful change was also reformulated and redefined as "neither the expectation nor the preparation for organized violence as a means to settle interstate disputes." ${ }^{162}$ By redefining peaceful change in such a manner, Adler and Barnett were

\footnotetext{
${ }^{158}$ Ibid. p. 258

${ }^{159}$ Ibid.

${ }^{160}$ Ibid. p. 250

${ }^{161}$ See: Emanuel Adler, Michael Barnett, "Security Communities in Theoretical Perspective," in Security Communities, eds. Emanuel Adler and Michael Barnett (Cambridge: Cambridge University Press, 1998), p. 33; Richard A. Higgot and Kim Richard Rossal, "Australia and the Search for a Community in the 1990s," in Security Communities, eds. Emanuel Adler and Michael Barnett (Cambridge: Cambridge University Press, 1998), p. 265-294

${ }^{162}$ Emanuel Adler, Michael Barnett, "Security Communities in Theoretical Perspective," in Security Communities, eds. Emanuel Adler and Michael Barnett (Cambridge: Cambridge University Press, 1998), p. 34
} 
refining one of the conceptual problems raised in Deutsch's original definition, specifically, that peaceful change would only imply the absence of "large-scale physical force."163 Under the new definition, Adler and Barnett were contending that peaceful change referred not only to the absence of all levels of violence, but also the thought of using force and the preparation for its use. ${ }^{164}$ Thus, while conflict is still possible in a security community, what separates it from any other type of community is that the parties involved will retain a dependable expectation of the peaceful resolution of a conflict. ${ }^{165}$

Methodologically, Adler and Barnett created a three-tier framework to illustrate the process through which communities of states develop "dependable expectations of peaceful change" and, thus, form security communities. ${ }^{166}$ The first tier focuses on precipitating conditions, such as changes in technology, demographics, economics, and the environment, as well as new interpretations of social reality and evaluations of external threats. ${ }^{167}$ These conditions propel states to engage each other in order to coordinate their relations. While there is no expectation that these encounters will produce trust and mutual identification, they are necessary conditions for that possibility. ${ }^{168}$

\footnotetext{
${ }^{163}$ Karl W. Deutsch, Sidney A. Burrell, Robert A. Kann, and Maurice Lee Jr., Political Community and the North Atlantic Area: International Organization in the Light of Historical Experience (Princeton: Princeton University Press, 1957), p. 3

${ }^{164}$ This understanding of peaceful brings it close to the concept of "stable peace" as developed by Boulding. See: Kenneth E. Boulding, Stable Peace (Austin: University of Texas Press, 1978), p. 13

${ }^{165}$ Emanuel Adler, Michael Barnett, "Security Communities in Theoretical Perspective," in Security Communities, eds. Emanuel Adler and Michael Barnett (Cambridge: Cambridge University Press, 1998), p. 33-34

${ }^{166}$ Ibid. p. 37

${ }^{167}$ Ibid. p. 37-38

${ }^{168}$ Ibid. p. 38
} 
The second tier focuses on the "positive, dynamic, and reciprocal relationship between the structure of the region defined by material power and knowledge, and social processes, defined by organizations, transactions, and social learning." ${ }^{.169}$ It is in this tier that states, as well as their citizens, become enmeshed in a series of social interactions that begins to transform the environment in which they are embedded. ${ }^{170}$ Additionally, it is expected that in this tier, the "structural" categories of power and knowledge, as well as the "process" categories of transactions, international organizations and institutions, and social learning, will develop a dynamic of reciprocity which, in turn, provide the conditions that lead to the emergence of collective identity and mutual trust. ${ }^{171}$ It is from these that dependable expectations of peaceful change arise. In other words, the third and final tier. ${ }^{172}$

Through this tiered framework, Adler and Barnett formulated a new typology that illustrated the development process of pluralistic security communities and distinguished between three phases: nascent, ascendant, and mature. Each of these phases is reflected in the processes encapsulated by the three tiers. In addition to the three phases, a further refinement is provided for the mature phase of pluralistic security communities. Adler and Barnett distinguished between loosely coupled and tightly coupled mature security communities. A loosely coupled security community possesses the "minimal definitional properties and no more: a transnational region comprised of sovereign states whose people

\footnotetext{
${ }^{169}$ Ibid. p. 37

${ }^{170}$ Ibid. p. 39

${ }^{171}$ Ibid.

${ }^{172}$ Ibid. p. $37 \& 45$
} 
maintain dependable expectations of peaceful change." ${ }^{173}$ On the other hand, a tightly coupled security is more demanding for two reasons. First, they have a "mutual aid" society that possesses collective system arrangements. Second, they possess a "system of rule that lies somewhere between a sovereign state and a regional, centralized, government; that is, it is something of a post-sovereign system, endowed with common supranational, transnational, and national institutions and some form of a collective security system."174

It is in tightly coupled pluralistic security communities that the identities of the people are derived from the identity and norms of the community itself as opposed to the nation-state or the international system. Additionally, even the role of the state emanates from the community. In essence, the identity of the people and the interests of the state are exchangeable with those of the community. ${ }^{175}$ Consequently "the discourse of the state and the language of legitimation, moreover, also should reflect that the relevant community is no longer coterminous with the state's territorial boundaries but rather with the region." 176 In other words, even though the state remains legally sovereign, its function is defined by the community.

These phases, or stages of development, are path-dependent. Since security communities are socially constructed, they have a "history, and therefore, exhibit an evolutionary pattern." ${ }^{177}$ As a result, the origins and paths of a security community's

\footnotetext{
${ }^{173}$ Ibid. p. 30

${ }^{174}$ Ibid.

${ }^{175}$ Ibid. p. $47-48$

${ }^{176}$ Ibid. p. 48

${ }^{177}$ Ibid. p. 49
} 
development will vary considerably. Adler and Barnett contended that initial choices made by social groups, even if they are small and random, determine future trajectories. Thus, taking these paths precludes others. These initial choices persist because social groups come to identify and benefit from past choices, as well as the fact that the cost of change increases over time. ${ }^{178}$ It is important to note, however, that although the model that is presented is evolutionary and seemingly "follows the "arrow of time,", there are situations in which security communities may disintegrate. ${ }^{179}$

\section{Security Complexes}

The concept of security complexes, like that of security communities, focuses primarily on security as the main variable for delineating as well as understanding regions. Additionally, both concepts also envision regions as socially constructed, although, rather than being constructed through "shared meanings, constituted by interaction, engender collective identities" as security communities are, security complexes are constructed through the security practices of the constituent actors. ${ }^{180}$ Furthermore, there are key differences in the concepts as well as their intended purpose. Developed by Barry Buzan, security complexes were originally defined as "a group of states whose primary concerns

\footnotetext{
${ }^{178}$ Ibid.

${ }^{179}$ Ibid. p. 57-58

${ }^{180}$ Barry Buzan and Ole Waever, Regions and powers: The Structure of International Security (Cambridge: Cambridge University press, 2003), p. 48
} 
link together sufficiently closely that their national securities cannot realistically be considered apart from one another." 181

Security complexes were developed as a means to distinguish regions as separate units of analysis in the international system. For Buzan, regions meant that a "distinct and significant subsystem of security relations exists among a set of states whose fate is that they have been locked into geographical proximity with each other." ${ }^{182}$ Thus, two immediate differences appear between security complexes and security communities. Namely, that the former is explicitly meant to be used as an analytical tool to study regions as separate units of analysis, and that the variable of geography is central to the definition of regions. An additional two distinctions are also present between these two concepts. Security complexes are intended to illustrate regional balance of power as well as regional order. Thus, unlike security communities which focus on the process of integration leading to the attainment of peaceful change, security complexes focus on the distribution of power and the patterns of amity and enmity which can lead to cooperation between states or to the use of force. ${ }^{183}$

After a key contribution by Ole Waever, the concept of security complex was refined. Waever's contribution came in the form of synthesizing Securitization Theory with the concept of security complexes. Securitization Theory is a language theory that regards

\footnotetext{
${ }^{181}$ Barry Buzan, People, States, and Fear: An Agenda for International Security Studies in the Post-Cold War Era $2^{\text {nd }}$ Edition (New York: Harvester Wheatsheaf, 1991), p. 190

182 Ibid. p. 188

${ }^{183}$ Ibid. p. 189
} 
“security” as a speech-act. ${ }^{184}$ Thus, by “uttering 'security,' a state-representative moves a particular development into a specific area, and thereby claims a special right to use whatever means are necessary to block it." ${ }^{185}$ In other words, Securitization is a speech-act that that elevates non-politicized and politicized issues to the security realm. ${ }^{186}$ These speech-acts allow an actor, usually elites within a state, to declare a referent object as existentially threatened. When a referent object becomes securitized, it is differentiated from politicized issues through a heightened sense of urgency and by facilitating the usage of extraordinary measures. Consequently, actions outside the bounds of societal and international norms become justified. ${ }^{187}$

Using this synthesis, "security complex" was redefined to mean "a set of units whose major processes of securitization, desecuritization, or both are so interlinked that their security problems cannot be reasonably analyzed or resolved apart from one another." 188 This modification of the concept allows for a broader understanding of security and regions as a result of its de-emphasis on a state-centric, military-political, conceptualization of security. ${ }^{189}$ Additionally, the variables of amity and enmity remain

\footnotetext{
${ }^{184}$ Ole Waever, "Securitization and Desecuritization," in On Security, ed. Ronnie Lipschutz (New York: Columbia University Press, 1995), p. 55

${ }^{185}$ Ibid.

${ }^{186}$ Michael C. Williams, "Words, Images, Enemies: Securitization and International Politics," International Studies Quarterly 47, 2003, p. 511-531

${ }^{187}$ Ibid.

${ }^{188}$ Barry Buzan, Ole Waever, and Jaap de Wilde, Security: A New Framework for Analysis (Boulder: Lynne Rienner Publichers Inc., 1998), p. 201

${ }^{189}$ Barry Buzan and Ole Waever, Regions and powers: The Structure of International Security (Cambridge: Cambridge University press, 2003), p. 44
} 
central to the concept since they provide the foundation for securitization and desecuritization processes. In other words, amity and enmity reveal the historical patterns of relations between states which, in turn, inform security perceptions and their subsequent securitization or desecuritization processes.

Buzan and Waever incorporated their new definition of security complexes in the development of Regional Security Complex Theory (RSCT). Under RSCT, security complexes become synonymous with regional security complexes (RSC). Although the new definition of security complexes, and RSCs as it is used in RSCT, adds the important dynamic of language to the concept, it retains many of the original assumptions from the first iteration. The first assumption is that RSCT continues to establish regions as separate units of analysis. ${ }^{190}$ These regions are demarcated through the lens of security, albeit in a broader sense as a result of its incorporation of securitization language. As Buzan and Waever state, regions exhibit "durable patterns of amity and enmity taking the form of subglobal, geographically coherent patterns of security interdependence. The particular character of a local RSC will often be affected by historical factors such as long-standing enmities."191

The second assumption extends from the first. That is, regions under RSCT are still envisioned as geographically clustered. Since regions are defined through security interdependence "the logic of territoriality continues to operate strongly," 192 particularly

\footnotetext{
${ }^{190}$ Ibid. p. 27

${ }^{191}$ Ibid. p. 45

192 Ibid. p. 11-12
} 
since geographic proximity has the greatest impact on security interaction along the political, military, societal, and environmental sectors. ${ }^{193}$ Thus, Buzan and Waever expect processes of securitization and the degree of security interdependence to be more intense between states inside an RSC than outside of it. ${ }^{194}$

Based on these characteristics, the essential structure of regional security complexes embodies four variables. The first is a boundary that allows for the differentiation of between RSCs. This functions as the geographic component. The second is the anarchic nature of RSCs which means that RSC's must be composed of two or more autonomous units. The third is polarity which focuses on the distribution of power between the constituent units. Collectively, the second and third variables refer to the order component of security complexes. The fourth, and last, variable is the social construction of regions. This refers to the patterns of amity and enmity within an RSC. ${ }^{195}$ In addition to these variables, RSC's are considered to be dynamic in the sense that they can evolve. Buzan and Waever contended that there were three possible evolutions available for RSCs. The first is that RSCs could maintain the status quo, in which there would be no significant change to the structure. The second is internal transformation, which refers to a change in the essential structure of an RSC within its existing borders. This may involve a change in the anarchic structure of the RSC as a result of regional integration, a change in polarity due to disintegration, merger, conquest, or differential growth rates, and, finally, a change

\footnotetext{
${ }^{193}$ Ibid. p. 45

${ }^{194}$ Ibid. p. 4 \& 46

${ }^{195}$ Ibid. p. 53
} 
in the dominant patterns of amity and enmity as a result of ideological shifts, war-weariness, and changes in leadership. The third possible evolution is the external transformation of the RSC which refers to a change in the boundary of the region through expansion or contraction. As a result, the membership of the RSC changes, but more importantly, so does its essential structure. ${ }^{196}$

In their development of RSCT, Buzan and Waever formulated a typology of RSCs based on their polarity. These ranged from standard, centered, great power, and Supercomplex RSC's. In standard RSCs, polarity was determined by regional powers. Centered RSCs were further divided based on whether polarity was defined by a single superpower, a great power, or an institution. Great power RSCs were defined by their bipolarity or multipolarity between great powers. Lastly, supercomplexes exhibited strong interregional security dynamics as a result of great power spillover into adjacent regions. ${ }^{197}$ In addition to their polarity, Buzan and Waever made a distinction in the types of patterns of amity and enmity exhibited in a given RSC, ranging from conflict formation, security regimes, and security communities. ${ }^{198}$ This typology reflected Wendt's own Hobbesian, Lockean, and Kantian Social Structures. ${ }^{199}$ As a result, regions can be defined by patterns of rivalries, balances, alliances, as well as concerts and friendships. ${ }^{200}$

\footnotetext{
${ }^{196}$ Ibid.

${ }^{197}$ Ibid. p. 62

${ }^{198}$ Ibid. p. 53-54

${ }^{199}$ Alexander Wendt, Social Theory of International Relations (Cambridge: Cambridge University Press, 1999)

${ }^{200}$ Barry Buzan and Ole Waever, Regions and Powers: The Structure of International Security (Cambridge: Cambridge University press, 2003), p. 55
} 
It is important to note that although the concept of security community is evoked in Buzan and Waever's work, they are referring to something fundamentally different than Deutsch, Adler, and Barnett. While the latter conceptualizes security communities as entities that have integrated and in which there is a dependable expectation of peaceful change, the former see the emergence of security communities as a result of desecuritization, while still exhibiting patterns of securitization. The key distinction is that in Deutsch's as well as Adler and Barnett's work, security communities exist in a condition where security, as Buzan and Waever understand it, is no longer a preoccupation. In the context of Securitization Theory, this would be a condition of total desecuritization. However, based on the definition of RSCs, this would mean the end of the security complex since security would no longer be a variable. ${ }^{201}$ Thus, for Buzan and Waever, while a security community may exhibit patterns of desecuritization, security continues to be a key variable. In fact, they contend that "the most mature cases of security communities today are not marked by a general forgetting of security concerns but rather by a conscious aggregation of them."202

\section{"New" Regionalism}

\section{The New Regionalism Approach}

The first wave of regionalism, identified as "old regionalism" and primarily driven by the neo-functionalist vs. inter-governmentalist debate, was galvanized by a specifically

\footnotetext{
${ }^{201}$ Ibid. p. 56-57

202 Ibid. p. 57
} 
European phenomenon: regional integration. In a similar fashion, the emergence of what has been labeled the "New Regionalism Approach" exhibits a similar historical contingency. As Bjorn Hettne and Fredrik Soderbaum, NRA's primary proponents, contend, the second wave of regionalism was the result of interrelated developments leading to the structural transformation of the world." ${ }^{203}$ These included: (1) the transition from the bipolar structure of the Cold War era to a multipolar one after the collapse of the USSR; (2) the relative decline of American hegemony and a more positive outlook by the United States on regionalism; (3) the erosion of the Westphalian nation-state system resulting from greater levels of interdependence and the forces of globalization; and finally, (4) changed attitudes towards neoliberal economic development and its associated political system in developing countries. ${ }^{204}$

These structural changes influenced a different type of regionalism that, according to Hettne and Soderbaum, integration theories of old regionalism were not well-suited to account for ${ }^{205}$ In other words, the second wave of regionalism, encapsulated in NRA, presented a type of regionalism that was inherently different from that of old regionalism. Accordingly, Hettne identified five characteristics that distinguished the two waves of regionalism:

- "whereas the old was formed in a bipolar Cold War context, the new was taking shape in a multipolar world order, and in the context of globalization....

\footnotetext{
${ }^{203}$ Bjorn Hettne and Fredrik Soderbaum, "Theorizing the Rise of Regionness," New Political Economy 5(3), 2000, p. 457

${ }^{204}$ Ibid.

${ }^{205}$ See: Bjorn Hettne and Fredrik Soderbaum, "The New Regionalism Approach," Politeia 17(3), 1998, p. 1-18; Bjorn Hettne and Fredrik Soderbaum, "Theorizing the Rise of Regionness," New Political Economy 5(3), 2000, p. 457-472; Bjorn Hettne, “Beyond 'New' Regionalism,” New Political Economy 10(4), 2005, p. $543-571$
} 
- Whereas the old was created 'from above', the new was a more voluntary process from within the emerging regions, where the constituent states and other actors experienced the imperative of cooperation, an 'urge to merge', or the pooling of sovereignty in order to tackle new global challenges.

- Whereas, in economic terms, the old was inward-oriented and protectionist, the new was often described as 'open', and thus compatible with an interdependent world economy. In fact there is today no alternative, closure no longer being an option.

- Whereas the old was specific with regard to its objectives (some organizations being primarily security-motivated, others more economically oriented), the new was resulting from a more comprehensive and multidimensional societal process.

- Whereas the old was concerned with relations between a group of neighbouring nationstates, the new formed part of a global structural transformation, or globalization, in which also a variety of non-state actors were operating at several levels of the global system."206

Hettne was not alone in identifying distinctions between old and new regionalism. Andrew

Hurrell also identified five characteristics that separated the old from the new. A key difference rested on the fact that new regionalism was more diverse in nature, particularly in its structure and processes of development. ${ }^{207}$ Additionally, there was a greater trend of North-South regionalism, which was markedly different from the North-North and SouthSouth dynamics previously envisioned in old regionalism. There was also greater diversity in the level of institutionalization. According to Hurrell, regional groupings were "consciously avoiding the institutional and bureaucratic structures of traditional international organizations and of the regionalist model represented by the EU."208 Another feature of new regionalism identified by Hurrell was its multi-dimensional character, which

\footnotetext{
${ }^{206}$ Bjorn Hettne, "The New Regionalism Revisited," in Theories of New Regionalism: A Palgrave Reader, eds. Fredrik Soderbaum and Timothy M. Shaw (New York: Palgrave MacMillan, 2003), p. 22-42

${ }^{207}$ Andrew Hurrell, "Explaining the Resurgence of Regionalism in World Politics," Review of International Studies 21(4), 1995, p. 331-332

${ }^{208}$ Ibid. p. 332
} 
referred to the blurring of the boundary between economic and political regionalism. This is similar to Hettne's fourth characteristic outlined above. Lastly, Hurrel contended that "many parts of the world have seen a marked increase in regional awareness or regional consciousness, even if this is not always easily or unproblematically translated into concrete schemes for regional cooperation." 209

These differences outlined by Hettne and Soderbaum, as well as by scholars like Hurrel, motivated the former to call for a research agenda around new regionalism that would take into account these new global dynamics. Although they contend that it might be premature to develop a theory on new regionalism, they nonetheless outlined the parameters of what such a theory should incorporate. This outline is encapsulated in New Regionalism Theory (NRT). New Regionalism Theory is intended to be a theory of world order, its transformation, and the emergence of a multilevel pattern of governance. ${ }^{210}$ Accordingly, Hettne and Soderbaum contend that NRT "has to explain the world order that makes processes of regionalization possible, or even necessary, and the world order that may result from new regionalisms in interaction." ${ }^{211}$ The focus on world order stems from the linkage between new regionalism and the structural changes outlined above. Consequently, new regionalism cannot be understood from the point of view of a single

\footnotetext{
${ }^{209}$ Ibid.

${ }^{210}$ Bjorn Hettne and Fredrik Soderbaum, "Theorizing the Rise of Regionness," New Political Economy 5(3), 2000, p. 458

${ }^{211}$ Ibid.
} 
region. In other words, NRT is a "global theory that takes regional peculiarities into consideration." 212

In their development of NRT, Hettne and Soderbaum incorporated key refinements to the terminologies for studying regions that they had introduced in the NRA. Of particular importance was the conceptual distinction between regionalism and regionalization. As previously stated, regionalism is defined as a "tendency and a political commitment to organize the world in terms of regions; more narrowly, the concept refers to a specific regional project." ${ }^{213}$ As a result, regionalism is normally associated with a program or strategy that may lead to formal institution-building. ${ }^{214}$ Regionalization on the other hand, refers to the "complex process of forming regions." ${ }^{215}$ In other words, it "denotes the (empirical) process that leads to patterns of cooperation, integration, complementarity, and convergence within a particular cross-national geographical space." ${ }^{216}$ Regionalization then, implies a change in regionness, a concept that is introduced to examine the state of regionalization in a given region. Thus, regionness "defines the position of a particular region in terms of regional cohesion, which can be seen as a long-term historical process,

\footnotetext{
212 Ibid. p. 459

${ }^{213}$ Bjorn Hettne, “Beyond 'New’ Regionalism,” New Political Economy 10(4), 2005, p. 545

214 Ibid.

215 Ibid.

${ }^{216}$ Bjorn Hettne and Fredrik Soderbaum, "Theorizing the Rise of Regionness," New Political Economy 5(3), 2000, p. 457-458
} 
changing over time from coercion, the building of empires and nations, to voluntary cooperation."217

Making a conceptual distinction between regionalism and regionalization also allows for the analytical distinction between "formal" regions and "real" regions. The former refers to state-led processes of regional organization through institutions and is considered to be of second order. ${ }^{218}$ These remain important, but are not the focus of NRA, and by extension, NRT. On the other hand, the latter exemplifies a "region in the making" through a multitude of actors. ${ }^{219}$ Through this distinction, Hettne and Soderbaum contend that it is possible to have regionalism without regionalization and vice versa. ${ }^{220}$

By rejecting regions as naturally given, ${ }^{221}$ and instead proposing that they are "in the making," regionalization is referring to their social construction. ${ }^{222}$ This brings it in line with Adler and Barnett's conception of regions, however, as its definition indicates,

${ }^{217}$ Bjorn Hettne, “Beyond 'New’ Regionalism,” New Political Economy 10(4), 2005, p. 548

${ }^{218}$ See: See: Bjorn Hettne and Fredrik Soderbaum, "The New Regionalism Approach," Politeia 17(3), 1998, p. 5; Bjorn Hettne and Fredrik Soderbaum, "Theorizing the Rise of Regionness," New Political Economy 5(3), 2000, p. 464-465; Bjorn Hettne, "The New Regionalism Revisited," in Theories of New Regionalism: A Palgrave Reader, eds. Fredrik Soderbaum and Timothy M. Shaw (New York: Palgrave MacMillan, 2003), p. 24

${ }^{219}$ See: Bjorn Hettne and Fredrik Soderbaum, "Theorizing the Rise of Regionness," New Political Economy 5(3), 2000, p. 464-465; Bjorn Hettne, "The New Regionalism Revisited," in Theories of New Regionalism: A Palgrave Reader, eds. Fredrik Soderbaum and Timothy M. Shaw (New York: Palgrave MacMillan, 2003), p. 24

${ }^{220}$ See: Bjorn Hettne and Fredrik Soderbaum, "The New Regionalism Approach,” Politeia 17(3), 1998, p. 5; Bjorn Hettne and Fredrik Soderbaum, "Theorizing the Rise of Regionness," New Political Economy 5(3), 2000, p. 458

${ }^{221}$ Bjorn Hettne and Fredrik Soderbaum, “The New Regionalism Approach,” Politeia 17(3), 1998, p. 5

${ }^{222}$ Bjorn Hettne and Fredrik Soderbaum, "Theorizing the Rise of Regionness," New Political Economy 5(3), 2000, p. 460 
geography remains an important variable for regionalization. Additionally, there is an important distinction between the geographic component of old regionalism and new regionalism. Old regionalism, in its reliance on formal regions as its basis, sees regions defined by regional institutions and their member states. ${ }^{223}$ In other words, the boundaries of the region are those of the states that make up any given institution. New regionalism, on the other hand, conceptualizes regions as more than a simple aggregation of states, thus, it has a more comprehensive understanding of the geographic component of regions. In essence, NRT recognizes "that the regional frontier may very well cut through a particular state's territory, positioning some parts of the state within the emerging region and others outside." 224

New Regionalism Theory encapsulates a synthesis of three theoretical approaches. The first is Global Social Theory (GST). This theory, also developed by Hettne and Soderbaum, proposes an ontological separation from state-centrism. ${ }^{225}$ It calls for a merger of certain strands of development theory and international political economy, in an effort to strengthen an emerging critical political economy that focuses on the "historical power structures and emphasising contradictions in them, as well as change and transformation

\footnotetext{
${ }^{223}$ Bjorn Hettne, "The New Regionalism Revisited," in Theories of New Regionalism: A Palgrave Reader, eds. Fredrik Soderbaum and Timothy M. Shaw (New York: Palgrave MacMillan, 2003), p. 24

${ }^{224}$ Bjorn Hettne and Fredrik Soderbaum, "Theorizing the Rise of Regionness," New Political Economy 5(3), 2000, p. 462

${ }^{225}$ See: Bjorn Hettne and Fredrik Soderbaum, “Towards Global Social Theory," Journal of International Relations and Development 2(4), 1999, p. 358-368; Bjorn Hettne and Fredrik Soderbaum, "Theorizing the Rise of Regionness," New Political Economy 5(3), 2000, p. 459
} 
expressed in normative terms." 226 The purpose is to "escape from unchanging transhistorical theory, artificially imposed on an ever changing reality, and still characterising mainstream international theory" such as international relations and international political economy. ${ }^{227}$ Additionally, GST with its focus on global structural change, and particularly, globalization, sheds light on the relationship between macro and micro regions since it posits that the distinction between the international and national is being transcended. ${ }^{228}$

The second theoretical approach that is incorporated into NRT is Social Constructivism. With its focus on the interaction between material incentives, intersubjective structures, as well as the identity and interests of actors, Social Constructivism allows NRT to explore the social construction of regions. ${ }^{229}$ Hettne and Soderbaum not only contend that there are no naturally given regions, but also that there are no naturally given regionalist interests either. Thus, they conclude that "such interests and identities are shaped in the process of interaction and intersubjective understanding." ${ }^{230}$ However, no interaction is possible without interests, which illustrates the importance of understanding

\footnotetext{
${ }^{226}$ Bjorn Hettne and Fredrik Soderbaum, "Theorizing the Rise of Regionness," New Political Economy 5(3), 2000, p. 459

${ }^{227}$ Ibid.

${ }^{228}$ See: Bjorn Hettne and Fredrik Soderbaum, “Towards Global Social Theory,” Journal of International Relations and Development 2(4), 1999, p. 358-368; Bjorn Hettne and Fredrik Soderbaum, "Theorizing the Rise of Regionness," New Political Economy 5(3), 2000, p. 459-460

${ }^{229}$ Bjorn Hettne and Fredrik Soderbaum, "Theorizing the Rise of Regionness," New Political Economy 5(3), 2000, p. 460

${ }^{230}$ Ibid.
} 
regionalization as a process. ${ }^{231}$ Social Constructivism also allows NRT to bring agency into the process of structural change. Using Alexander Wendt's argument that "structure has no existence or causal power apart from process" 232 as a basis, Hettne and Soderbaum contend that to understand structural change, there needs to be a move from the structure to agency, actors, and strategies. ${ }^{233}$ As a result, NRT looks at the role that states, as well as non-state actors, play in the process of regionalization. The third, and final, building block that serves as a foundation or NRT is Comparative Studies. While the Hettne and Soderbaum contend that comparative analysis should be used with great care in the social sciences, they believe that it helps guard against ethnocentric bias as well as culture-bound interpretations that arise from deep specialization. ${ }^{234}$ Additionally, they conclude that the generalizations that are made through the comparative method are crucial for theory-building. Ultimately, by focusing on comparative regional studies in a globalized framework, NRT can look at particular regions in a "world of regions," which together constitute an emerging world order marked by regional peculiarities. ${ }^{235}$ Thus, looking at regions and their formation is a core component of the theory.

${ }^{231}$ Ibid.

232 Alexander Wendt, "Anarchy is What States Make of it: The Social Construction of Power Politics," International Organization 56(2), 1992, p. 395

${ }^{233}$ Bjorn Hettne and Fredrik Soderbaum, "Theorizing the Rise of Regionness," New Political Economy 5(3), 2000, p. 460

234 Ibid. p. 461

235 Ibid. 
For Hettne and Soderbaum, a region emerges from the process of regionalization, and they may be distinguished from each other by their level of regionness. Identifying regions, they contend, requires "making judgements about the degree to which a particular area in various respects constitutes a distinct entity, which can be distinguished as a relatively coherent territorial subsystem (in contrast with non-territorial subsystems) from the rest of the global system." ${ }^{236}$ Furthermore, as multiple processes of regionalization across multiple sectors (political, economic, cultural, etc.), intensify and converge within the same geographical area, the cohesiveness and distinctiveness of a region "in the making" increases. ${ }^{237}$ This understanding of regions is flexible, particularly at lower stages of regionness since the borders of the region are likely to be more porous at those stages.

Since regionness is a core component for assessing regions as well as basis for regional comparison, Hettne and Soderbaum created a typology of regionness that distinguishes between five levels. The first level, the regional space, is primarily delimited by natural physical barriers and marked by ecological characteristics. As a result, the region is deeply rooted in territory. In social terms, this territory is "organized by human inhabitants, at first in relatively isolated communities, but more and more creating some kind of translocal relationship." 238 This translocal relationship reflects the dynamic

\footnotetext{
${ }^{236}$ Ibid.

${ }^{237}$ Ibid.

${ }^{238}$ Bjorn Hettne, "The New Regionalism Revisited," in Theories of New Regionalism: A Palgrave Reader, eds. Fredrik Soderbaum and Timothy M. Shaw (New York: Palgrave MacMillan, 2003), p. 28
} 
character of regionalization and gives rise to more complex social systems, resulting in the second level of regionness: regional complex.

Regional complexes reflect an expansion of translocal relations between human groups. At this level, the regional system is anarchic and is normally organized through a balance of power. Paradoxically, the region is united through its conflicts, and the regionalization process is typically coercive. ${ }^{239}$ In security terms, Hettne and Soderbaum compare this level of regionness to Buzan and Waever's RSC, particularly one exhibiting the patterns of amity and enmity of a "conflict formation." 240 Similarly, the economic sector at this stage exhibits no transnational welfare mechanism. If interdependency exists at this stage it is bound to be exploitative rather than cooperative. Consequently, economic relations devolve into protectionism, trade wars, and beggar-thy-neighbor policies. ${ }^{241}$

The third level of regionness is regional society. At this stage, the regionalization process intensifies as a number of different actors emerge at different societal levels and move towards the transcendence of the national space. Actors also begin to use a rule-based pattern of relations. ${ }^{242}$ It is during this period that "formal," or de jure, regions may emerge, although the "real," or de facto, region can still be said to exist due to the convergence of

\footnotetext{
${ }^{239}$ Ibid.

${ }^{240}$ See: Bjorn Hettne and Fredrik Soderbaum, "Theorizing the Rise of Regionness," New Political Economy 5(3), 2000, p. 464; Bjorn Hettne, "The New Regionalism Revisited," in Theories of New Regionalism: A Palgrave Reader, eds. Fredrik Soderbaum and Timothy M. Shaw (New York: Palgrave MacMillan, 2003), p. 28

${ }^{241}$ Bjorn Hettne and Fredrik Soderbaum, "Theorizing the Rise of Regionness," New Political Economy 5(3), 2000, p. 464

${ }^{242}$ Ibid.
} 
multiple sectors. ${ }^{243}$ Hettne and Soderbaum liken this level of regionness to the English School's concept of international society in the context of regional cooperation. However, they differ from the English School since NRT does not focus solely on the state. Although it is expected that nascent stages of regionness will be dominated by a state-centric logic, and this stage is no different, by this point increased interdependence would have given rise to complex interactions among a wider range of actors. ${ }^{244}$ It is important to note that greater levels of regionness does not imply that the nation-state is losing relevance or disappearing. Nevertheless, it does it does mean that they are undergoing major restructuring in the context of regionalization, globalization, and the complex interplay of state-market-society relations. ${ }^{245}$

From regional society emerges regional community, the fourth level of regionness. A regional community refers to a region that is gradually becoming "an active subject with a distinct identity, institutionalized or informal actor capability, legitimacy and structure of decision making in relation with a more or less responsive regional civil society, transcending the old state borders." ${ }^{246}$ A regional community forms through enduring organization frameworks, which may be formal or informal, that facilitate and promote social communication as well as the convergence of values in the region. This process produces a transnational civil society that is characterized by greater intensity of social

\footnotetext{
${ }^{243}$ Ibid. p. 464-465

${ }^{244}$ Ibid. p. 465

${ }^{245}$ Ibid.

${ }^{246}$ Ibid. p. 466
} 
trust at the regional level. ${ }^{247}$ As a result, much like Deutsch's, and Adler and Barnett's conceptualization of pluralistic security communities, Hettne and Soderbaum's conceptualization contend that at this stage of regionness, solving conflicts through violent means becomes inconceivable. ${ }^{248}$

Another important characteristic of regional communities is the mutually reinforcing relationship between "the 'formal' region, defined by the community of states, and the 'real' region, in which a transnationalised regional civil society also has a role to play." 249 This dynamic is critical since a regional civil society, even if it emerges spontaneously from "below," is largely dependent on enduring institutions, formal or informal, and "regimes" due to the fact that they promote security, welfare, social communication as well as the convergence of values, norms, identities and actions throughout the region. ${ }^{250}$ As the "formal" and "real" region continues to converge, the separation of national communities within a region will begin to erode and differentiation increasingly occurs between societies inside the regions and those outside of it. ${ }^{251}$ It is this level of regionness that begins to link directly with the world order component of NRT

\footnotetext{
${ }^{247}$ Bjorn Hettne, "The New Regionalism Revisited," in Theories of New Regionalism: A Palgrave Reader, eds. Fredrik Soderbaum and Timothy M. Shaw (New York: Palgrave MacMillan, 2003), p. 29

${ }^{248}$ See: Bjorn Hettne and Fredrik Soderbaum, "Theorizing the Rise of Regionness," New Political Economy 5(3), 2000, p. 466; Bjorn Hettne, "The New Regionalism Revisited," in Theories of New Regionalism: A Palgrave Reader, eds. Fredrik Soderbaum and Timothy M. Shaw (New York: Palgrave MacMillan, 2003), p. 29

${ }^{249}$ Bjorn Hettne and Fredrik Soderbaum, "Theorizing the Rise of Regionness," New Political Economy 5(3), 2000, p. 466

${ }^{250}$ Ibid.

${ }^{251}$ Ibid. p. 467
} 
since regions becoming active subjects marks a radical shift from how the world has been organized in the Westphalian era. ${ }^{252}$

The fifth and last level of regionness is the region-state or regional institutionalized polity. ${ }^{253}$ This entity has a stronger actor capacity and a better-defined structure of decision-making. ${ }^{254}$ A region-state is conceptually different from a nation-state since the former is not expected to achieve the same level of homogeneity and sovereignty that is regularly attributed to traditional Westphalian states. This is due to the fact that the process of homogenization that occurs in nation-states through cultural standardization, often along ethnic lines, is not replicated in regionalization. Rather, regionalization is expected to be heterogeneous and exhibit a pluralist culture. ${ }^{255}$ As should be evident in the five-level process, region-states cannot be formed through force, rather, they constitute a voluntary evolution of a group of formerly sovereign national communities into a new type of entity in which sovereignty is pooled. Therefore, authority, power and decision making are not centralised but layered, decentralised to the local, micro-regional, national and macroregional/supranational levels."256

${ }^{252}$ Ibid.

${ }^{253}$ Both terms are used interchangeably, although Hettne's and Soderbaum's recent work utilizes the latter terminology. For region-state see: Bjorn Hettne and Fredrik Soderbaum, "Theorizing the Rise of Regionness," New Political Economy 5(3), 2000, p. 466; for regional institutionalized polity see: Bjorn Hettne, "The New Regionalism Revisited," in Theories of New Regionalism: A Palgrave Reader, eds. Fredrik Soderbaum and Timothy M. Shaw (New York: Palgrave MacMillan, 2003), p. 29

${ }^{254}$ Bjorn Hettne, "The New Regionalism Revisited," in Theories of New Regionalism: A Palgrave Reader, eds. Fredrik Soderbaum and Timothy M. Shaw (New York: Palgrave MacMillan, 2003), p. 29

${ }^{255}$ Bjorn Hettne and Fredrik Soderbaum, "Theorizing the Rise of Regionness," New Political Economy 5(3), 2000, p. 467

256 Ibid. 
These five levels of regionness are evolutionary. Nevertheless, it is possible for regions to ascend to or descend from these levels based on changing dynamics within a region. Thus, since regionalization is a political project, created by human actors, there is always a possibility that it may fail. ${ }^{257}$ Nevertheless, the NRA, and NRT by extension, presents a compelling basis for assessing regional formation and transformation in the context of systemic structural changes.

\section{The Region-Building Approach}

The region-building approach proposed by Iver B. Neumann emerged with the second wave of regionalism in the 1990s. It is heavily influenced by nation-building literature, particularly Benedict Anderson's work on imagined communities. ${ }^{258}$ Like the scholars focused on security communities, complexes, as well as those in the second wave of regionalism, Neumann contends that regions are socially constructed. As a result, regions are expected to be in a constant state of being defined and redefined by its constituent members as they attempt to situate themselves at the core of the region. ${ }^{259}$ This regional core is defined in territorial and functional terms, thus, it involves the manipulation

\footnotetext{
${ }^{257}$ Bjorn Hettne, "The New Regionalism Revisited," in Theories of New Regionalism: A Palgrave Reader, eds. Fredrik Soderbaum and Timothy M. Shaw (New York: Palgrave MacMillan, 2003), p. 29

${ }^{258}$ See: Iver B. Neumann, “A Region-Building Approach to Northern Europe,” Review of International Studies 20(1), 1994, p. 53-74; Iver B. Neumann, "A Region-Building Approach," in Theories of New Regionalism: A Palgrave Reader, eds. Fredrik Soderbaum and Timothy M. Shaw (New York: Palgrave MacMillan, 2003), p. 160-178; Benedict Anderson, Imagined Communities: Reflections on the Origins and Spread of Nationalism (London: Verso, 1983)

${ }^{259}$ Iver B. Neumann, “A Region-Building Approach to Northern Europe," Review of International Studies 20(1), 1994, p. 53
} 
of knowledge and power. ${ }^{260}$ In other words, regions, much as Hettne and Soderbaum contend, are constantly "in the making."

Nation-building looks at how elites give meaning to territorial space. As Neumann posits, "if the nation-state's reality in space is testified to by its territory, its reality in time is a question of getting itself a history." 261 An important characteristic of this process is that the construction of a nation-state from dubious or questionable historical material does not necessarily detract from its reality once it is territorially bounded, although it may throw its identity into doubt. ${ }^{262}$ This process is done by "identifying, and thus making relevant to the identity of the human collective in question, a host of political ties, cultural similarities, economic transactional patterns and so on."263

In essence, a region-building approach incorporates the nation-building framework in order to assess how regions are constructed, and more importantly, identify who the regional builder(s) are. ${ }^{264}$ From this perspective, regions are seen as political projects which are enacted by region-builders. Thus, the existence of regions is preceded by regionbuilders, in this case elite political actors that, as part of a political project, imagine a certain

\footnotetext{
260 Ibid.

${ }^{261}$ Iver B. Neumann, “A Region-Building Approach,” in Theories of New Regionalism: A Palgrave Reader, eds. Fredrik Soderbaum and Timothy M. Shaw (New York: Palgrave MacMillan, 2003), p. 160

262 Ibid.

263 Ibid.

${ }^{264}$ See: Iver B. Neumann, “A Region-Building Approach to Northern Europe,” Review of International Studies 20(1), 1994, p. 53-74; Iver B. Neumann, “A Region-Building Approach," in Theories of New Regionalism: A Palgrave Reader, eds. Fredrik Soderbaum and Timothy M. Shaw (New York: Palgrave MacMillan, 2003), p. 160-178
} 
spatial and chronological identity for a region, and then proceed to disseminate this imagined identity to others. ${ }^{265}$ There are, however, two key differentiations between nation-building and region-building. The first is that unlike nation-builders, regionbuilders do not necessarily see the creation of regions as a prelude to the creation of a political entity. This is something that is, by definition, central to nation-builders. The second is that region-building is entangled with the question of state sovereignty in ways that differ from that of nation-building. ${ }^{266}$

The region-building approach uses a genealogical method in order to unearth the power/knowledge nexus in the creation of regions. More specifically, it provides two important insights. The first is the focus on a politically constitutive and politically motivated clash of definitions which is considered to be constantly occurring. The second, is that regions are constituted through speech-acts. In other words, regions are talked into existence by political actors, the region-builders. ${ }^{267}$ As a result, rather than take state interests as given and then project them at the regional level in order to extrapolate the actor's regional project, the region-building approach investigates how interests are generated through discourse. ${ }^{268}$ Consequently, Neumann posits that "where every region-

\footnotetext{
265 Iver B. Neumann, “A Region-Building Approach to Northern Europe,” Review of International Studies 20(1), 1994, p. 58

${ }^{266}$ Iver B. Neumann, “A Region-Building Approach,” in Theories of New Regionalism: A Palgrave Reader, eds. Fredrik Soderbaum and Timothy M. Shaw (New York: Palgrave MacMillan, 2003), p. 161

${ }^{267}$ Iver B. Neumann, “A Region-Building Approach to Northern Europe,” Review of International Studies 20(1), 1994, p. 59

${ }^{268}$ Iver B. Neumann, “A Region-Building Approach,” in Theories of New Regionalism: A Palgrave Reader, eds. Fredrik Soderbaum and Timothy M. Shaw (New York: Palgrave MacMillan, 2003), p. 162
} 
builder's goal is to make the region-building programme as natural as possible, the approach aims to expose its historically contingent character," 269 and "where a region has been part of a discourse for so long that it is taken as a given fact, the approach can show that structures which may at first sight seem to be inevitably given, will only remain so as long as they are perceived as inevitably given." 270

The region-building approach provides important insights into the construction of regions. Rather than concentrating on what Neumann terms "inside-out" approaches that focus on cultural integration, or "outside-in" approaches that focus on geopolitics, the regional-building approach is offered as a perspective that dots the margins of the ongoing debate. It does this by asking the crucial questions of how and why regions brought into existence, as well as what actors perpetuate this existence and with what intentions. Additionally, it assesses how scholars studying and writing about regions, through their exclusion of certain areas and peoples from a given region, are also contributing to the perpetuation or transformation or a region. ${ }^{271}$

\section{Region-Building through State-Building}

As is evident in the material discussed, the study of regions, their formation, and transformation, is a relatively recent phenomenon in international relations. This sub-field emerged as a result of European integration and transformation and was revitalized after the collapse of the USSR. Although far from exhaustive, the literature presented above

\footnotetext{
${ }^{269}$ Ibid.

${ }^{270}$ Ibid.

${ }^{271}$ Ibid.
} 
demonstrates a maturation in the sub-field through greater refinement of key concepts; federalism, neo-functionalism, and inter-governmentalism, focused on integration and the formation of supranational entities such as regional organizations and institutions. There was a regional component insofar as this process of integration and institution-building was more likely to occur among geographically proximate states. Although concerned with the process of integration, these three approaches explained the phenomena from different perspectives. Federalism did so through a legalistic approach, neo-functionalism through spillover dynamics, and inter-governmentalism through a government-led negotiation process. Nevertheless, despite the fact that all three of these approaches, especially federalism and neo-functionalism, were motivated by conditions of insecurity, security itself was not a primary variable in the theories.

On the other hand, the research on security communities placed security as a central variable. Security communities focused on integration through interactions that, in time, created the condition of stable peace. An important contribution made by this approach is the social construction of regions, thus moving away from the a priori assumption that regions are naturally given. Like security communities, security complexes also focused on security as the main variable for defining regions and conceived regions as socially constructed. However, rather than integration, the main focus of security complexes, and RSCT by extension, was on regional order and transformation. Furthermore, a key differentiation between security communities and security complexes was that the former removed the geographic variable of regions, while the latter reinforced it.

The NRA, and the NRT that was developed from it, expands on the concept of regions as socially constructed. It does this by introducing concepts like regionalization 
and regionness, and by distinguishing between "formal" and "real" regions. As a result, NRT is not only capable of evaluating regional integration through the lenses offered by federalism, neo-functionalism, and inter-governmentalism, the "formal" region, but also through the lens of non-state actors through greater social interactions caused by global structural changes such as globalization. In other words, the "real" region. Although it shares similarities to RSCT in the sense that it incorporates both, local and systemic processes, NRT takes into account a greater number of actors and variables. Furthermore, although both possess a geographic component in their theory, NRT has a more fluid conception of territoriality since it moves beyond the traditional "formal" definition of regions.

Finally, the region-building approach provides insight into how regions are constructed through narratives underpinned by domestic interests in the constituent units. This approach fills an important gap that although alluded to by all theories that conceive regions as socially constructed, is often ignored in their application. Thus, rather than take interests as naturally given, the region-building approach aims to locate the domestic narratives that forge national interests that are then externally projected in region-building processes. As a result, it is able to address important questions such as who are the regionbuilders and what are their underlying motivations to pursue the region-building project? Furthermore, the region-building approach can provide insight into the demarcation of the geographical boundaries of the region, thus locating the builder's position within the region, the members that exist within its conception of the region, and those who are excluded. In other words, this approach unearths the political process of regional formation and transformation. 


\section{Framework of the Study}

This study employs a simple synthesis between the region-building approach and the concept of regionalization in the NRA to uncover how Chinese narratives about regions emerge, and trace the empirical process of how China constructs and transforms regions. It does this by utilizing a framework that focuses on how domestic elite-led narratives about security and development result in domestic state-building initiatives. Furthermore, it examines how the narratives driving domestic state-building initiatives may need a regionbuilding project in order to improve the likelihood of their success. This component of the framework relies on the region-building approach and assesses how domestic interests are transformed into foreign policy. The narratives behind this political process reveal the purpose of the region, the place that the builder occupies within its conception of the region, and who it envisions as members of the region. Lastly, by utilizing the concept of regionalization, the framework traces the empirical process of regional formation and transformation.

For conceptual distinction and clarity, it should be noted that state-building differs from nation-building as the latter implies the process of constructing national identity, as indicated by Benedict Anderson's work, while the former implies control of territory in addition to the penetration of societies by the state through its bureaucracy and other state apparatuses. In other words, it represents state capacity and the ability of the state to enforce 
policy throughout its territory. ${ }^{272}$ Region-building projects on the other hand, are state narratives behind the empirical process that leads to patterns of "cooperation, integration, complementarity, and convergence within a particular cross-national geographical space." 273 In other words, region-building projects galvanize the process of regionalization, by naturalizing and legitimizing the project through narratives. The narratives behind region-building projects legitimate a country's inclusion by establishing the historicity of its engagement with the region. They also serve the purpose of demarcating the geographical parameters of the region by identifying which states are crucial to its statebuilding efforts. Furthermore, these narratives also define the function of the region based on the purpose of the state-building initiative. This framework allows better understanding of how region-building, in addition to increasing interdependence, can also facilitate a state's capacity to exercise control of its territory and increase its ability to provide economic development.

This study will look at the narratives behind the state-building initiatives in western China, particularly narratives about Xinjiang and the role it plays in these initiatives. Consequently, the study will focus on the region-building projects that emerge from these state-building initiatives. Since Eurasia is a massive continent with dozens of countries, the empirical examples will focus on China's most immediate Eurasian neighbors, in addition

\footnotetext{
272 See: Charles Tilly, The Formation of National States in Western Europe (Princeton: Princeton University Press, 1975); Michael Mann, "Ruling Class Strategies and Citizenship," in The State: Critical Concepts Volume III, ed. John A. Hall (New York: Routledge, 1994), p. 40-56

${ }^{273}$ Bjorn Hettne and Fredrik Soderbaum, "Theorizing the Rise of Regionness," New Political Economy $5(3), 2000$, p. 457-458
} 
to states that emerge as critical components of China's domestic state-building efforts, and by extension, its region-building project. 


\section{Chapter 2: 1991-2000: National Integration and Regional Formation}

The collapse of the Soviet Union presented China with a number of challenges. One of the most immediate was the need to delineate and demarcate its border with the Russian Federation, Kazakhstan, Kyrgyzstan, and Tajikistan, which bordered China after the Soviet collapse. Another important issue that needed to be addressed was the reduction of the high levels of military personnel deployed along the border by both sides since the 1960s as a result of the clashes that occurred during the Sino-Soviet split. The demilitarization of the border was important since it would help ease cross-border tensions and pave the way for the normalization of relations between the PRC and its post-Soviet neighbors. Additionally, demilitarization would also lessen the economic pressure that this level of forward deployment was having on the parties involved and facilitate greater flow of goods across their respective borders. Therefore, there was an important economic motivation to the negotiations. ${ }^{274}$ In order to justify any reduction in border forces, however, the Russian Federation, Kazakhstan, Kyrgyzstan, and Tajikistan needed to be assured that China would respect their sovereignty and act in good faith during border demarcation negotiations in this moment of extreme uncertainty. Lastly, the most important challenge that emerged immediately after the collapse of the USSR was the independence of the Central Asian republics. The independence of Central Asian republics, which are primarily populated by Turkic people, once again raised the specter of separatism in China's Xinjiang province,

\footnotetext{
${ }^{274}$ See: Herbert J. Ellison and Bruce A. Acker, “The New Russia in Asia: 1991-1995,” The National Bureau of Asian Research 7(1), 1996, p. 36, http://www.nbr.org/publications/analysis/pdf/vol7no1.pdf; Russell Ong, "China's Security Interests in Central Asia," Central Asian Survey 24(4), 2005, p. 427
} 
and consequently, threatened to undermine Chinese control over the province. ${ }^{275}$ This was a major concern for the CCP since Xinjiang possesses a sizeable Uyghur population which shares ethno-linguistic, religious, and historical links to the peoples of Central Asia. Furthermore, beyond sharing ethno-linguistic links, these republics possessed a sizeable Uyghur diaspora as well. ${ }^{276}$

History was not lost in the minds of the CCP leadership. Since its formal incorporation to the Qing Empire in 1884, Xinjiang has consistently been a restive province and, during times of internal strife in China, has formally declared independence. In fact, not accounting for the Dungan Rebellion in the $19^{\text {th }}$ century, separatist groups in Xinjiang established an East Turkestan Republic in the 1930s, and again in the 1940s, before being reincorporated to the PRC in 1949 by the People's Liberation Army. ${ }^{277}$ Furthermore, the Russian Empire, and later the USSR, had on numerous occasions fomented unrest and supported separatist groups within Xinjiang in order to destabilize Chinese central authorities and extract political and economic concessions. ${ }^{278}$ There was concern that the new republics would continue this practice post-independence. In fact, in the early 1990s evidence indicated that Central Asian republics continued to express support for Uyghur nationalism, something that did not begin to wane until Premier Li Peng's tour of the region

\footnotetext{
${ }^{275}$ Sebastien Peyrouse, "Discussing China: Sinophilia and Sinophobia in Central Asia," Journal of Eurasian Studies 7, 2005, p. 14-23

${ }^{276}$ Nicolas Becquelin, "Xinjiang in the Nineties," The China Journal 44, 2000, p. 66

${ }^{277}$ Hsiao-tin Lin, "Nationalists, Muslim Warlords, and the "Great Northwestern Development" in PreCommunist China," China and Eurasia Quarterly Forum 5(1), 2007, p. 115-135

${ }^{278}$ Allen S. Whiting, Sinkiang Pivot or Pawn? (East Lansing: Michigan State University Press, 1958) p. 714
} 
in $1994 .{ }^{279}$ As a result, there was a legitimate concern that the independence of the Central Asian republics would not only motivate the Uyghur population in Xinjiang to engage in separatist activities by virtue of example, and also that they could be supported by their Turkic cousins and co-religionists across the western border. ${ }^{280}$

Anxiety over growing unrest in Xinjiang after the Soviet collapse, and the danger that this unrest posed to China's territorial integrity, motivated the Chinese leadership to establish a closer relationship with Central Asian republics in order to cooperate against the "three evils" of terrorism, separatism, and extremism in order to more effectively exercise control of the province. Additionally, the CCP's domestic state-building efforts, driven by a narrative linking security and development, envisioned the simultaneous integration of Xinjiang and its opening to Eurasia in order to foster economic growth and development, something that was perceived as being critical for the political and social stability of the province. According to Party officials, Xinjiang's opening to Eurasia would be aided by its strategic position as the gateway to the region. ${ }^{281}$

However, linking Xinjiang to its western neighbors and beyond posed another set of challenges to the CCP's central authority. The first of these challenges was the fact that the opening of Xinjiang to its western neighbors would also involve greater access to potentially radical influences and groups. This fear was growing even before the Soviet

\footnotetext{
${ }^{279}$ Eric Hyer, “China’s Policy Towards Uighur Nationalism,” Journal of Muslim Minority Affairs 26(1), 2006, p. 81

${ }^{280}$ Russell Ong, “China’s Security Interests in Central Asia,” Central Asian Survey 24(4), 2005, p. 428

281 "Wang Enmao Addresses 16th Xinjiang Party Session,” Urumqi Xinjiang Ribao, March 14, 1991, FBIS-CHI-91-050, March 14, 1991
} 
collapse as a result of the "Baren Incident," that occurred in the Baren Township near Kashgar on April 5, 1990 which resulted in 22 officially announced deaths: fifteen civilians, six policemen, and a local official. ${ }^{282}$ The incident was reportedly carried out by Uyghurs who had received weapons as well as military and religious training from jihadist groups in neighboring Afghanistan. Thus, from the perspective of the $\mathrm{CCP}$, this incident marked an important development in the ever-present ethnic tensions in the province, namely, that inter-ethnic violence had taken a radical religious character. ${ }^{283}$ After the Soviet collapse, these events motivated $\mathrm{CCP}$ officials to proactively engage Central Asian republics in addition to Afghanistan and Pakistan since it was believed that Uyghur separatist groups were receiving religious indoctrination as well as combat training and materiel in these countries. ${ }^{284}$

The second challenge was the fact that as late as the 1990s, Xinjiang had very little infrastructure and was not effectively integrated into the rest of the country. This is particularly important when distinguishing between the northern and southern sections of the province. While the north may have had greater levels of development due to the higher presence of ethnic Han as well as the industrial investment from the USSR before the SinoSoviet split, the south, where most of the Muslim minorities lived, remained isolated and

\footnotetext{
282 “Song Hanliang Blames 'Separatists,” Hong Kong AFP, April 25, 1990, FBIS-CHI-90-080, April 25, 1990

${ }^{283}$ Pablo Adriano Rodriguez, "Violent Resistance in Xinjiang (China): Tracking Militancy, Ethnic Riots and "Knife-Wielding' Terrorists," Historia Actual Online 30, 2013, p. 137

${ }^{284}$ See: P. Stoban, “China’s Central Asia Dilemma," Strategic Analysis 22(3), 1998, p. 400; Eric Hyer, "China's Policy Towards Uighur Nationalism," Journal of Muslim Minority Affairs 26(1), 2006, p. 81; Yitzhak Shichor, "The Great Wall of Steel: Military and Strategy in Xinjiang," in Xinjiang: China's Muslim Borderland, ed. S. Fredrick Starr (Armonk: M.E. Sharpe, 2004), p. 144-145
} 
underdeveloped. In fact, until 1995, only one decent road connected Urumqi, the capital of the province, to the most populated city, Kashgar, located in the south. ${ }^{285}$ Due to the lack of infrastructure linking Xinjiang to the rest of China, there was a concern that opening up to Eurasian countries without addressing this issue would expose its minorities to extremist ideologies, thus drawing the province away from Beijing and limiting its ability to exercise effective control. In other words, there was a need to increase the connectivity of Xinjiang to the rest of the country not only to provide economic opportunities, but also to increase the ability of the CCP to exercise control. The last challenge that the CCP faced was the fact that as a result of its Open Door Policy and the subsequent prioritization of coastal development, the national economy was becoming increasingly fragmented. ${ }^{286}$

As a result, of these challenges, the CCP concluded that opening up Xinjiang to its western neighbors would have to occur simultaneously with its integration into the rest of the country. In other words, it was recognized that Xinjiang's development and, consequently, its political stability, would have to occur through the synchronization of national integration and regional opening. This meant that domestic state-building imperatives needed to be linked to a regional-building project. Furthermore, Xinjiang's development was crucial since throughout its history, the province has been a key source of financial drain on successive Chinese governments. ${ }^{287}$

\footnotetext{
${ }^{285}$ Nicolas Becquelin, "Xinjiang in the Nineties," The China Journal 44, 2000, p. 68

${ }^{286}$ Gaye Christoffersen, "Xinjiang and the Great Islamic Circle: The Impact of Transnational Forces on Chinese Regional Economic Planning," The China Quarterly 133, 1993, p. 130-151

${ }^{287}$ See: Andrew D.W. Forbes, Warlords and Muslims in Chinese Central Asia: A Political History of Republican Sinkiang 1911-1949 (Cambridge: Cambridge University Press, 1986), p. 28; Peter C. Perdue, China Marches West: The Qing Conquest of Central Eurasia (Massachusetts: The Belknap Press of Harvard University Press, 2005), p. 357
} 


\section{Xinjiang and the "Double-Opening" Strategy}

The simultaneous process of integrating Xinjiang into the rest of China and opening it to its western neighbors was encapsulated in the "double-opening" strategy. As Tumur Dawamet, the Chairman of Xinjiang (1985-1993), explained, this strategy not only involved the opening up to the "Soviet Union, Mongolia, and countries in South Asia, the Middle East and Western Europe, but also to the rest of China to its east."288 The logic underlying this double-opening strategy was that the economic development of Xinjiang would lead to political and social stability, and that political and social stability would lead to economic development. In fact, Dawamet's successor, Abdulahat Abdurixit (19932003), stated that "on the one hand, we must use economic development to maintain political stability, and on the other hand, we must use political stability to guarantee economic development." 289 Thus, there was a co-constitutive relationship between security and development, although it is unclear which condition was initially required to begin this cycle. Nevertheless, the role of the Party in this process was explicit as Party officials indicated that it was only through the CCP that political stability and economic development could be ensured. In other words, the "virtuous cycle" of security, stability, and economic development, a security-development nexus, necessitated the centralization of the CCP's authority, and in the context of Xinjiang, integration of the province into the rest of the country. Wang Enmao, Communist Party Secretary of Xinjiang (1952-1967,

\footnotetext{
288 "Xinjiang Governor Explains Open Door Program," China Daily (Business Weekly), July 10, 1989, FBIS-CHI-89-133, July 13, 1989

${ }^{289}$ Nan Zhu, "PRC: Xinjiang Chairman Cautions Against Ethnic Splittism,” Urumqi Xinjiang Ribao, April 21, 1991, FBIS-CHI-96-097, May 17, 1996
} 
1981-1985), reflected this understanding of the party's role in the security-development nexus. He contended that the party had to deliver economic development through the opening of Xinjiang, while simultaneously ensuring its stability through the strengthening of the Party and its presence in the province. ${ }^{290}$ Song Hanliang, his successor (1985-1994), echoed the same sentiment in his own address to the Fourth Xinjiang Uygur Autonomous Regional CPC Congress in March 14, 1991. ${ }^{291}$

\section{Nationally Integrating Xinjiang}

As a result of the security-development nexus logic underlying the double-opening strategy, the CCP pursued a number of policies that would directly result in the greater integration of Xinjiang into the rest of China as well as its opening to its western neighbors. In essence, the double-opening strategy was a state-building initiative that would necessitate a region-building project. Integration with the rest of China, the state-building component, possessed a political, economic, and social dimension. Political integration was envisioned as the strengthening of the people's democratic dictatorship. This component focused on the role of the Party in the provision of political and social stability. Thus, establishing political and social stability required the strengthening of the state apparatus, particularly through the promotion of judicial and public security work and training the contingent of workers that were to make these reforms possible. Part of this

\footnotetext{
290 "Wang Enmao Addresses 16th Xinjiang Party Session," Urumqi Xinjiang Ribao, March 14, 1991, FBIS-CHI-91-050, March 14, 1991

291 "Song Hanliang Gives Xinjiang CPC Report," Urumqi Xinjiang Ribao, March 23, 1991, FBIS-CHI-91071, April 12, 1991
} 
process was the need to reform the legal system in order to ensure that there would be laws for people to follow in "every aspect of political, economic, and social life," as well as ensure that these laws would be "strictly observed and enforced." 292 Additionally, the People's Liberation Army (PLA), a core pillar of the people's democratic dictatorship, was to play an important role in safeguarding the political and social stability of the province. Thus, during a visit to Xinjiang in the summer of 1991, Wang Zhen, Vice-President of the PRC (1988-1993), called on the PLA to "form a steel wall to safeguard socialism and the unification of the motherland." 293 This act gave central government legitimacy to the role the PLA played in maintaining stability and fostering the development of the province. The concept of the PLA providing a "steel wall" against separatism and unrest was promoted by Deng Xiaoping in the aftermath of the Tiananmen student-led protests, therefore, its application to other parts of the country was considered natural. ${ }^{294}$ In fact, Xi Jinping relies on this narrative in contemporary discourse about the role of the Party and the PLA in maintaining stability in Xinjiang. ${ }^{295}$

A key target of these political reforms and the increased presence of the PLA was separatist groups, which the CCP considered to be the primary instigators of instability and violence in Xinjiang. In his address, noted above, Song Hanliang reflected this sentiment

\footnotetext{
${ }^{292}$ Ibid.

${ }^{293}$ J. Richard Walsh, "China and the New Geopolitics of Central Asia," Asian Survey 33(3), 1993, p. 272

294 "Deng says his Open-Door Policies Will Not Change: Hails 'Great Wall of Iron and Steel,"' Los Angeles Times, June 9, 1989, http://articles.latimes.com/1989-06-09/news/mn-1828_1_deng-xiaoping-mensquare-china-s-great-wall

295 Tom Phillips, “China: Xi Jinping wants ‘Great Wall of Steel' in Violence-hit Xinjiang,” The Guardian, March 10, 2017, https://www.theguardian.com/world/2017/mar/11/china-xi-jinping-wants-great-wall-ofsteel-in-violence-hit-xinjiang
} 
by stating that "nationalism inside and outside the country is the main source of danger affecting Xinjiang stability." ${ }^{296}$ These domestic and international separatist elements were perceived as an effort to separate Xinjiang from the "big family of the motherland."297 Thus, Yang Shangkun, President of the PRC (1988-1993), during a visit to Xinjiang in December 1991, urged the party and the PLA "to restore order, rally the minorities under Party rule, strengthen combat readiness and pluck by the root the shoots of ethnic disunity and rebellions." 298 This meant that the sporadic events of unrest and violence in the province validated Party state-building efforts to centralize power in Xinjiang and pursue its greater integration into the rest of China.

An important tool of political, economic, and social control utilized by the CCP in Xinjiang has been the Xinjiang Production and Construction Corps (XPCC). Founded in 1954 by Wang Zheng under orders from Mao Zedong, ${ }^{299}$ the XPCC is a "productive force equipped with arms. Situated in the border area and in the front line of the struggle against revisionism and imperialism, it shoulders the heavy combat task of guarding the frontier of the mother country." ${ }^{300}$ In other words, it is a paramilitary organization that focuses on the

\footnotetext{
296 “Song Hanliang Gives Xinjiang CPC Report," Urumqi Xinjiang Ribao, March 23, 1991, FBIS-CHI-91071, April 12, 1991

${ }^{297}$ Ibid.

${ }^{298}$ Lillian Craig Harris, "Xinjiang, Central Asia and Implication for China's Policy in the Islamic World," The China Quarterly 133, 1993, p. 118

${ }^{299}$ See: Yitzhak Shichor, "The Great Wall of Steel: Military and Strategy in Xinjiang," in Xinjiang: China's Muslim Borderland, ed. S. Fredrick Starr (Armonk: M.E. Sharpe, 2004), p. 150; "The Conqueror of China's Wild West," Asia Sentinel, April 13, 2008, https://www.asiasentinel.com/politics/the-conquerorof-chinas-wild-west/

${ }^{300}$ Yitzhak Shichor, "The Great Wall of Steel: Military and Strategy in Xinjiang," in Xinjiang: China's Muslim Borderland, ed. S. Fredrick Starr (Armonk: M.E. Sharpe, 2004), p. 151
} 
protection of the frontier areas and the reclamation of land for agricultural purposes. At its inception, the XPCC was primarily composed of demobilized PLA troops, Guomindang forces that had surrendered after the end of the Chinese Civil War (1927-1949), East Turkestan Republic forces that had surrendered as the PLA advanced on Xinjiang, as well as political and criminal prisoners. ${ }^{301}$ Over time, however, it has become the primary vehicle through which the $\mathrm{CCP}$ has promoted Han migration into Xinjiang, particularly in the western and southern regions of Xinjiang where the Han have had little presence. ${ }^{302}$

The role that the XPCC plays has historical precedent. Dating back to the Han Dynasty (206 B.C.E.-220C.E.), successive Chinese governments have "adopted the practice of stationing troops to cultivate and guard frontier areas as an important state policy for developing border areas and consolidating frontier defense." ${ }^{303}$ There was a practical purpose for making the troops garrisoning the empire's frontiers cultivate the land, namely, that the only way to provision an army in such a remote region was by making it self-sufficient. ${ }^{304}$ These farming garrisons generally increased Han presence in frontier

\footnotetext{
${ }^{301}$ See: "The Conqueror of China's Wild West," Asia Sentinel, April 13, 2008, https://www.asiasentinel.com/politics/the-conqueror-of-chinas-wild-west/; Stanley W. Stoops, "The Demography of Xinjiang," in Xinjiang: China's Muslim Borderland, ed. S. Fredrick Starr (Armonk: M.E. Sharpe, 2004), p. 246; David Bachman, "Making Xinjiang Safe for the Han? Contradiction and Ironies of Chinese Governance in China's Northwest," in Governing China's Multiethnic Frontiers, ed. Morris Rossabi (Seattle: University of Washington Press, 2004), p. 157

302 David Bachman, "Making Xinjiang Safe for the Han? Contradiction and Ironies of Chinese Governance in China's Northwest," in Governing China's Multiethnic Frontiers, ed. Morris Rossabi (Seattle: University of Washington Press, 2004), p. 176

303 "Establishment, Development and Role of the Xinjiang Production and Construction Corps," Information Office of the State Council of the People's Republic of China, 2003, http://www.china.org.cn/e-white/20030526/index.htm

${ }^{304}$ Calla Weimer, "The Economy of Xinjiang," in Xinjiang: China's Muslim Borderland, ed. S. Fredrick Starr (Armonk: M.E. Sharpe, 2004), p. 165
} 
regions, thus enhancing the central government's ability to exercise control along the margins. The XPCC can be considered the most recent iteration of this ancient practice, although it possesses far greater capability and autonomy than its predecessors. In other words, the XPCC is a state-building tool that follows the historical precedent of using Han migration as a vehicle of territorial control.

Although the XPCC suffered a decline during the Cultural Revolution (1966-1976), and was dissolved in 1975, it was restored in $1981 .^{305}$ Throughout the 1980s the XPCC was under the jurisdiction of the Ministry of Agriculture, although by 1990 it was placed under the direct supervision of the State Council. ${ }^{306}$ This means that the XPCC is not under the control of the Xinjiang government, although it must operate under its existing laws and regulations. Therefore, the XPCC "handles its own administrative and judicial affairs within the reclamation areas under its administration." 307 In the fourteen "reclamation areas," each representing a division, the XPCC is engaged in a wide range of economic activities beyond farming such as mining, industry, construction, transportation, finance, electricity generation, and water works. In addition to these activities, the XPCC functions

\footnotetext{
305 "Establishment, Development and Role of the Xinjiang Production and Construction Corps," Information Office of the State Council of the People's Republic of China, 2003, http://www.china.org.cn/e-white/20030526/index.htm

${ }^{306}$ Calla Weimer, “The Economy of Xinjiang," in Xinjiang: China's Muslim Borderland, ed. S. Fredrick Starr (Armonk: M.E. Sharpe, 2004), p. 170

307 "Establishment, Development and Role of the Xinjiang Production and Construction Corps," Information Office of the State Council of the People's Republic of China, 2003, http://www.china.org.cn/e-white/20030526/index.htm
} 
as a welfare state for its members, administering its own schools, hospitals, laboratories, pension funds, police force, courts, prisons, and even labor camps. ${ }^{308}$

Sometimes referred as a "state within a state," 309 the XPCC maintains a significant political, economic, and social presence in Xinjiang. Through a "four-in-one" system, the militia arm of the XPCC cooperates with the PLA, the People's Armed Police (PAP), and ordinary people, in efforts aimed at resisting internal and external separatist attempts at sabotage and infiltration. Therefore, for the CCP, the XPCC plays a key role in "maintaining the stability and safety of the borders of the motherland." 310 Furthermore, the XPCC also provides security to important infrastructure, particularly the pipelines that distribute oil and gas to other parts of the PRC. ${ }^{311}$ In other words, the organization is a unique manifestation of CCP political control in Xinjiang. It is unique because there is no other equivalent organization operating in other provinces in the PRC, thus illustrating the exceptional position of the province even among other traditionally restive areas like Tibet.

\footnotetext{
${ }^{308}$ See: Christian Tyler, Wild West China: The Taming of Xinjiang (New Brunswick: Rutgers University Press, 2004), p. 194-195; Calla Weimer, "The Economy of Xinjiang," in Xinjiang: China's Muslim Borderland, ed. S. Fredrick Starr (Armonk: M.E. Sharpe, 2004), p. 169-170; "Establishment, Development and Role of the Xinjiang Production and Construction Corps," Information Office of the State Council of the People's Republic of China, 2003, http://www.china.org.cn/e-white/20030526/index.htm

${ }^{309}$ See: David Bachman, "Making Xinjiang Safe for the Han? Contradiction and Ironies of Chinese Governance in China's Northwest," in Governing China's Multiethnic Frontiers, ed. Morris Rossabi (Seattle: University of Washington Press, 2004), p. 175; Christian Tyler, Wild West China: The Taming of Xinjiang (New Brunswick: Rutgers University Press, 2004), p. 194

310 "Establishment, Development and Role of the Xinjiang Production and Construction Corps," Information Office of the State Council of the People's Republic of China, 2003, http://www.china.org.cn/e-white/20030526/index.htm

311 “The Conqueror of China's Wild West," Asia Sentinel, April 13, 2008, https://www.asiasentinel.com/politics/the-conqueror-of-chinas-wild-west/
} 
Throughout the 1990s, the XPCC's membership was estimated to be around 2.4 million, meaning that XPCC membership constituted about an eighth of Xinjiang's total population during this period. Additionally, ninety percent of the membership was ethnic Han, thus, as indicated above, the XPCC has served as the primary vehicle for Han migration into the province as well as a key player in the demographic transformation of Xinjiang over the past couple of decades. ${ }^{312}$ While initial Han settlers may have been forcibly resettled during the Maoist period in order to alleviate population pressures in other provinces, since the 1990s, the XPCC has aided the process of demographic change by actively encouraging and recruiting poor Han from other interior provinces to settle in Xinjiang. ${ }^{313}$ Consequently, this demographic change is leading to the erosion of Uyghur ethnic dominance in the region as more and more ethnic Hans migrate to Xinjiang, which in turn, allows for more effective control of the province by the CCP. ${ }^{314}$

The reach of the XPCC should not be understated, especially since it controls a significant proportion of productive assets in Xinjiang. It not only directly administers a number of cities in Xinjiang, but also controls about a third of its arable land. ${ }^{315}$ This has

\footnotetext{
${ }^{312}$ David Bachman, "Making Xinjiang Safe for the Han? Contradiction and Ironies of Chinese Governance in China's Northwest," in Governing China's Multiethnic Frontiers, ed. Morris Rossabi (Seattle: University of Washington Press, 2004), p. 175-176

${ }^{313}$ See: David Bachman, "Making Xinjiang Safe for the Han? Contradiction and Ironies of Chinese Governance in China's Northwest," in Governing China's Multiethnic Frontiers, ed. Morris Rossabi (Seattle: University of Washington Press, 2004), p. 176; Nicolas Becquelin, "Xinjiang in the Nineties," The China Journal 44, 2000, p. 76-77

${ }^{314}$ Nicolas Becquelin, "Xinjiang in the Nineties," The China Journal 44, 2000, p. 77-78

${ }^{315}$ See: Christian Tyler, Wild West China: The Taming of Xinjiang (New Brunswick: Rutgers University Press, 2004), p. 194; Nicolas Becquelin, "Xinjiang in the Nineties," The China Journal 44, 2000, p. 77-78
} 
allowed the XPCC to produce over a third of the province's sugar, cloth, canned goods, and paper, as well as roughly forty percent of its total cotton. ${ }^{316}$ In 1995 , the organization accounted for more than twenty-two percent of the total industrial production in Xinjiang and controlled roughly a quarter of its medium and large-sized enterprises throughout the decade. ${ }^{317}$ As a result, by 1997, the XPCC accounted for fourteen percent of Xinjiang's GDP, ${ }^{318}$ making it the single-most important conglomerate in the province. This is an important development since the CCP considers the XPCC as significant contributor to the modernization of the province, particularly through technology transfers from more developed regions in the PRC, as well as through the practice of sending its technicians to counties near its reclamation areas to train workers. ${ }^{319}$

Beyond using the XPCC as a state-building tool that acts as the vanguard for development and control in Xinjiang, the CCP directly invested in the development of critical infrastructure in Xinjiang throughout the 1990s in order to foster economic development, as well as further integrate the province to the rest of the country. This had the added benefit of ensuring that the exercise of central control was more responsive.

\footnotetext{
${ }^{316}$ Christian Tyler, Wild West China: The Taming of Xinjiang (New Brunswick: Rutgers University Press, 2004), p. 194; David Bachman, "Making Xinjiang Safe for the Han? Contradiction and Ironies of Chinese Governance in China's Northwest," in Governing China's Multiethnic Frontiers, ed. Morris Rossabi (Seattle: University of Washington Press, 2004), p. 176; Nicolas Becquelin, "Xinjiang in the Nineties," The China Journal 44, 2000, p. 78 \& 81

${ }^{317}$ David Bachman, "Making Xinjiang Safe for the Han? Contradiction and Ironies of Chinese Governance in China's Northwest," in Governing China's Multiethnic Frontiers, ed. Morris Rossabi (Seattle: University of Washington Press, 2004), p. 176

${ }^{318}$ Nicolas Becquelin, "Xinjiang in the Nineties," The China Journal 44, 2000, p. 78

319 "Establishment, Development and Role of the Xinjiang Production and Construction Corps," Information Office of the State Council of the People's Republic of China, 2003, http://www.china.org.cn/e-white/20030526/index.htm
} 
Xinjiang's abundant natural resources have been a source of interest since the early $20^{\text {th }}$ century. It was the discovery of oil in the Dushanzi field near Karamay, Xinjiang in 1909 that started the arduous process of industrializing the province. ${ }^{320}$ This process of industrialization has predominantly occurred in sectors focused on raw material extraction, something that has made the province a key supplier of raw goods to more developed provinces on the coast. ${ }^{321}$ The Eighth Five Year Plan (1991-1995) sought to integrate Xinjiang's economy into the rest of the country, particularly by capitalizing on its raw material endowments as well as its strategic position as the gateway to Eurasia. Thus, the plan called for greater investments in transportation and industrial infrastructure, increased agricultural and industrial output, and more effective linkages between the provincial and national economies. ${ }^{322}$

Transportation infrastructure was a priority for the CCP. Not only because it can facilitate the transportation of goods and consequently promote economic development, something that was of critical importance to the Party, but also because transportation infrastructure increases state capacity and presence. ${ }^{323}$ In other words, infrastructure, as a state-building tool, has an economic and political function that is dominated by the security-development nexus logic. As a key part of the Eighth Five Year Plan, in 1995 the

\footnotetext{
${ }^{320}$ Lili Lin and Zihan Shi, "Xinjiang's First Oil Well,” China Daily, July 10, 2015, https://www.chinadaily.com.cn/m/xinjiang/karamay/2015-07/10/content_21894342.htm

${ }^{321}$ Gaye Christoffersen, "Xinjiang and the Great Islamic Circle: The Impact of Transnational Forces on Chinese Regional Economic Planning," The China Quarterly 133, 1993, p. 130-151

322 “Wang Enmao Addresses 16th Xinjiang Party Session," Urumqi Xinjiang Ribao, March 14, 1991, FBIS-CHI-91-050, March 14, 1991

${ }^{323}$ Ibid.
} 
first of four highways running along the north-south axis of the province was completed. ${ }^{324}$ Collectively named the Tarim Desert Highway, these highways connect the more developed northern half of Xinjiang, where most Han living in the province reside, with the largely underdeveloped southern half of the province, where most Muslim minorities live. This was important since the southern half of the province is also where most resistance to the $\mathrm{CCP}$ emanates from. ${ }^{325}$ Furthermore, these highways provide access to Xinjiang's Tarim Basin oil deposits, thus paving the way for greater development of the province's petrochemical sector, a key goal of the Eighth Five Year Plan. ${ }^{326}$ By 1999, a key project of the Ninth Five Year Plan (1996-2000) was completed. This project was a railway extension that linked the central city of Korla with Kashgar, finally providing a more reliable and efficient connection between the north and south of the province, but more importantly, with its most populous and restive city. ${ }^{327}$

\section{Opening Xinjiang to Eurasia}

Beyond integrating Xinjiang into the rest of the country, the double-opening strategy also envisioned opening up the province to its western neighbors in order to

\footnotetext{
${ }^{324}$ See: “Tarim Desert Highway,” Baike Baidu, September 27, 2017, https://baike.baidu.com/item/\%E5\%A1\%94\%E9\%87\%8C\%E6\%9C\%A8\%E6\%B2\%99\%E6\%BC\%A0\%E 5\%85\%AC\%E8\%B7\%AF [In Mandarin]; "Tree Belt Built Across World's Longest Desert Highway," People's Daily, May 8, 2001, http://www.china.org.cn/english/12349.htm

${ }^{325}$ See: “'East Turkestan' Terrorist Forces Cannot Get Away With Impunity," Information Office of State Council, January 21, 2002, http://www.china.org.cn/english/2002/Jan/25582.htm; Pablo Adriano Rodriguez, "Violent Resistance in Xinjiang (China): Tracking Militancy, Ethnic Riots and "KnifeWielding' Terrorists," Historia Actual Online 30, 2013, p. 135-149

326 "Wang Enmao Addresses 16th Xinjiang Party Session,” Urumqi Xinjiang Ribao, March 14, 1991, FBIS-CHI-91-050, March 14, 1991

327 "Wild West Rail Link to Open up Trade, Tourism to Muslim Outposts," South China Morning Post, May 15, 1999, http://www.scmp.com/article/282092/wild-west-rail-link-open-trade-tourism-muslimoutposts
} 
generate economic activity as well as securing support for its control. This was the regionbuilding project component of the strategy. As indicated above, CCP leaders were cognizant of the strategic position of the province and its potential for establishing a "Eurasian Continental Bridge" and restoring the historical Silk Road. This is something that was explicitly mentioned in Wang Enmao's address in Xinjiang in 1991 and has been part of regular rhetoric from CCP officials since the open door policy was enacted by Deng Xiaoping. For example, during his visit to Tashkent, Uzbekistan, which was part of his 1994 tour of Central Asia, Li Peng stated that "the people of China and Uzbekistan have a traditional friendship which dates back to the times of the Silk Road." 328 These allusions to the historical Silk Road are commonplace for Chinese officials when speaking to their counterparts from neighboring countries. As will be discussed in the following chapters, this helps establish the historicity of China's engagement in Eurasia thus making it natural. Furthermore, it is part of its region-building project narrative as it reveals how Beijing positions itself within the region in addition to identifying which states it perceives as being part of its project.

Xinjiang's trade with its western neighbors had already resumed in the 1980s due to the warming of relations between the PRC and the USSR, and experienced positive growth through the rest of the decade. Thus, as part of the double-opening strategy, CCP officials sought to increase the number of border openings and crossings as well as develop

\footnotetext{
328 "Chinese Premier Leaves for Central Asia," United Press International, 1994, http://www.upi.com/Archives/1994/04/18/Chinese-premier-leaves-for-Central-Asia/5364766641600/
} 
landports in order to enhance trade with Eurasian states. ${ }^{329}$ In other words, there was a legitimate effort to increase physical links with Xinjiang's western neighbors in order to generate economic activity and promote development. Nevertheless, opening Xinjiang to its western neighbors posed its own set of challenges. As indicated above, there was a concern that this opening would expose Muslim minorities to radical ideologies or provide a safe haven for separatists groups seeking to undermine $\mathrm{CCP}$ authority in Xinjiang. ${ }^{330} \mathrm{As}$ a result, the double-opening strategy could not effectively move forward without the cooperation of China's neighbors, particularly on the issue of the three evils. However, cooperation on the three evils would be difficult to attain without addressing existing border issues between the PRC and its post-Soviet neighbors.

To generate support and garner cooperation from its neighbors, China not only needed to settle extant border disputes through their delineation and demarcation, it also needed to succeed in the demilitarization of its borders in order to build confidence. Furthermore, CCP leadership also needed to successfully socialize these nascent republics into its securitization of the three evils. In other words, China had to externalize its domestic discourse of the existential threat posed by the three evils in ways that would demonstrate the threat that these evils presented to the newly formed republics. It needed to resonate. Furthermore, it also needed to promote economic cooperation based on a mutual benefit, win-win relationship in order to deter potentially protectionist behavior from its neighbors, something that would undermine state-building efforts in Xinjiang.

\footnotetext{
${ }^{329}$ See: "Xinjiang Governor Explains Open Door Program," China Daily (Business Weekly), July 10, 1989, FBIS-CHI-89-133, July 13, 1989; "Wang Enmao Addresses 16th Xinjiang Party Session," Urumqi Xinjiang Ribao, March 14, 1991, FBIS-CHI-91-050, March 14, 1991

${ }^{330}$ P. Stoban, “China’s Central Asia Dilemma,” Strategic Analysis 22(3), 1998, p. 400
} 
Reaching this point, however, required the PRC and its former Soviet neighbors to address competing narratives of history and their impact on the question of their shared borders. Consequently, this phase would be dominated by the process of delineation, demarcation, and demilitarization of their borders and would mark the normalization of China's relations with the Russian Federation and its Central Asian neighbors. This would not only facilitate state-building efforts in the PRC, but also create the conditions for deeper Chinese engagement in Eurasia, thus marking the emergence of a region-building process.

\section{Unequal Treaties and the Sino-Soviet Split}

The borders inherited by the People's Republic of China in 1949 were the product of historical conquest, settlement, and unequal treaties signed during the $19^{\text {th }}$ century by the Qing Dynasty with European powers. Of particular importance regarding the negotiations with its post-Soviet neighbors were the treaties of Aigun (1858), Tientsin (1858), Peking (1860), Ili (1881) in which the Qing court was compelled to cede territory in Outer Northwest China and Outer Manchuria to the Russian Empire. These treaties are considered unequal "because they were not negotiated by nations treating each other as equals but were imposed on China after a war, and because they encroached upon China's sovereign rights ... which reduced her to semicolonial status." ${ }^{331}$ The fall of the Qing Dynasty in 1911 and the emergence of the Republic of China (ROC) meant that as the successor state, it would be responsible for upholding those four treaties. Although the

${ }^{331}$ Immanuel C.Y. Hsu, The Rise of Modern China (New York: Oxford University Press, 1970), p. 239 
nationalist government of the ROC sought to excise itself from these treaties, rather than immediately invalidate them, it opted to invoke the principle of rebus sic stantibus during negotiations in order to abrogate them. ${ }^{332}$

Interestingly, it was the Soviet Union that initiated the abrogation of its unequal treaties with the ROC. On September 20, 1920, the USSR signed an agreement with the ROC which stipulated that "the Government of Russian Socialist Federated Soviet Republics declares as void all the treaties concluded by the former Government of Russia with China, renounces al the annexation of Chinese territory, all the Concessions in China." 333 Following this agreement, on May 23, 1924, the two sides signed the "Agreement on General Principles for the Settlement of the Questions Between the Republic of China and the Union of Soviet Socialist Republics" in which Article 3 stipulated that both parties annulled

"all conventions, treaties, agreements, protocols, contracts, et cetera, concluded between the Government of China and the Tsarist Government and to replace them with new treaties, agreements, et cetera, on the basis of equality, reciprocity and justice, as well as the spirit of the declarations of the Soviet Government of the years of 1919 and 1920." 334

Additionally, Article 7 stated that "the two contracting parties agree to redemarcate their national boundaries." 335 This was something that directly addressed Chinese concerns about the formal demarcation of the Sino-Soviet border and the potential settling of

\footnotetext{
${ }^{332}$ Byron N. Tzou, China and International Law: The Boundary Disputes (New York: Praeger, 1990), p. 83 ${ }^{333}$ Ibid.

334 "Agreement on General Principles for the Settlement of the Questions Between the Republic of China and the Union of Soviet Socialist Republics," The American Journal of International Law 19(2), 1925, p. 53

${ }^{335}$ Ibid. p. 54
} 
contested territory resulting from unequal treaties. However, the conference that was scheduled to occur a month after this agreement was signed in order to carry out detailed arrangements of the articles never took place. Furthermore, although the 1924 agreement was perceived as a positive development, Chiang Kai-shek would later comment that the Nationalist Revolutionary Government was confined to Guangdong, thus making it impossible to conclude a formal treaty of equality. ${ }^{336}$ As a result, Chiang contended that the "frontier problems between China and Soviet Union [had] not been satisfactorily settled." 337

Like Chiang Kai-shek, Mao Zedong expressed dissatisfaction with the demarcation of China's borders, particularly those that had been the product of unequal treaties. In 1939, Mao remarked that China's defeat at the hands of imperial powers resulted in the seizure and leasing of its territory. ${ }^{338}$ However, due to his dependence on the Soviet Union for material and political support, Mao was careful to not specifically refer to the issues surrounding the Sino-Soviet boundary. ${ }^{339}$ This position would change once fissures emerged in his relationship with Stalin's successor in the USSR, Nikita Khrushchev, resulting in the Sino-Soviet split.

\footnotetext{
${ }^{336}$ Chiang Kai-shek, China's Destiny \& Chinese Economic Theory (New York: Roy Publishers, 1947), p. 154

${ }^{337}$ Ibid.

${ }^{338}$ Mao Tse-Tung, Selected Works of Mao Tse-Tung Volume II (Peking: Foreign Language Press, 1965), p. 311

${ }^{339}$ Byron N. Tzou, China and International Law: The Boundary Disputes (New York: Praeger, 1990), p. 80
} 
Nikita Khrushchev emerged as the General Secretary of the Central Committee of the Communist Party of the Soviet Union (CPSU) in 1953, unexpectedly surpassing many of his rivals to succeed Josef Stalin. Under Mao Zedong and Nikita Khrushchev respectively, relations between the PRC and the USSR would take a precipitous turn. While Mao's relation with Stalin was strained, the former tacitly accepted the latter's leadership of the Communist world. Upon Stalin's death, however, Mao believed that he was the best qualified individual to lead the international Communist movement. ${ }^{340}$ This sentiment was not lost on Khrushchev, who during his first visit to the PRC in 1954 remarked to a member of his delegation that "a conflict with China and us is inevitable." ${ }^{" 341}$ He drew his conclusion from "remarks Mao made" and the way in which the Soviet delegation was treated. ${ }^{342}$ In 1958, on his second visit to the PRC, Khrushchev would fare no better, especially after his "secret speech" titled "On the Cult of Personality and its Consequences" given to the $20^{\text {th }}$ Party Congress of the Communist Party of the Soviet Union in 1956 was leaked. In this speech Khrushchev formally denounced Stalin's despotism, cult of personality, and the purges he ordered against loyal party members under the label of "enemy of the people."343

\footnotetext{
${ }^{340}$ Chen Jian, Mao's China and the Cold War (University of North Carolina Press, 2001), p. 67-71

${ }^{341}$ Sergey Khrushchev, Memoirs of Nikita Khrushchev Volume 3, (University Park: Pennsylvania State University Press, 2007), p. 399

${ }^{342}$ Ibid.

${ }^{343}$ Nikita Sergeyevich Khrushchev, "Khrushchev's Secret Speech, 'On the Cult of Personality and its Consequences.' Delivered at the Twentieth Party Congress of the Communist Party of the Soviet Union," The Wilson Center Digital Archive, February 25, 1956, http://digitalarchive.wilsoncenter.org/document/115995
} 
Mao interpreted Khrushchev's speech against Stalinism as a direct affront to his own policies since those had been largely influenced by Stalin. ${ }^{344}$

The events of the Hungarian Revolution in 1956 presented Mao with the opportunity to critique Khrushchev's de-Stalinization policies and present himself and the $\mathrm{CCP}$ as being the most capable of leading the Communist camp. In the aftermath of the Hungarian Revolution, Mao took a strong position in reaffirming Stalin's policies. He contended that "there [were] two 'swords': one is Lenin and the other Stalin. The sword of Stalin has now been discarded by the Russians." ${ }^{345}$ Additionally, he argued that "[Stalinism is] just Marxism ... with shortcomings," stating that "the so-called de-Stalinization thus is simply de-Marxification, it is revisionism." 346 These statements allowed him not only to undermine Khrushchev, but also to validate his own policies. The rift that these declarations caused would only widen in the coming years.

In the summer of 1958, Khrushchev made his second visit to the PRC. Mao, not having forgotten the poor treatment he received from Stalin during his visit to the USSR in 1949, and keen on undermining Khrushchev, placed the entire Soviet delegation in an old establishment with no air conditioning to suffer the sweltering summer heat of Beijing. ${ }^{347}$ Knowing that Khrushchev had an aversion to cigarettes, Mao smoked throughout the first

\footnotetext{
${ }^{344}$ Lorenz M. Luthi, The Sino-Soviet Split: The Cold War in the Communist World (New Jersey: Princeton University Press, 2008), p. 49-50

345 Ibid. p. 62

${ }^{346}$ Ibid. p. 63

${ }^{347}$ Mike Dash, "Khrushchev in Water Wings: On Mao, Humiliation and the Sino-Soviet Split," Smithsonian, May 4, 2012, https://www.smithsonianmag.com/history/khrushchev-in-water-wings-on-maohumiliation-and-the-sino-soviet-split-80852370/
} 
day of negotiations in addition to mocking his guest for speaking too long, stating that "you have talked a long time but have still not gotten to the point." ${ }^{348}$ The following day, knowing that his Soviet counterpart did not know how to swim, Mao extended an invitation to the Soviet delegation to conduct negotiations in the pool of his private residence within the CCP's inner sanctum in Zhongnanhai. ${ }^{349}$ Although in his memoirs Khrushchev fondly remarks about his experience in the pool with Mao, ${ }^{350}$ in 1962 he revealed to an audience of artists and writers how he really felt, stating that "all the while I was swimming, I was thinking the hell with you." ${ }^{351}$ During this visit, Khrushchev had sought to get an agreement for the USSR to build a radio station in China as well as allow Soviet submarines to dock and resupply in Chinese ports, he would get neither. ${ }^{352}$

Khrushchev left the PRC embittered after this visit, and immediate events would only cement the downward spiral in Sino-Soviet relations. Following his 1958 visit to the PRC, the Second Taiwan Straits Crisis began after Mao ordered the shelling of Jinmen and Mazu, islands controlled by the ROC, taking his Soviet allies by surprise. ${ }^{353}$ The resulting American show of force and possibility of a nuclear war only helped convince Khrushchev that Mao was dangerous to the Communist bloc. By 1959, not only did the USSR renege

\footnotetext{
${ }^{348}$ William Taubman, Khrushchev: The Man and His Era (London: Simon \& Schuster, 2005), p. 390

${ }^{349}$ Ibid. p. 391

${ }^{350}$ Sergey Khrushchev, Memoirs of Nikita Khrushchev Volume 3, (University Park: Pennsylvania State University Press, 2007 ), p. 456

${ }^{351}$ William Taubman, Khrushchev: The Man and His Era (London: Simon \& Schuster, 2005), p. 391-392

${ }^{352}$ Sergey Khrushchev, Memoirs of Nikita Khrushchev Volume 3, (University Park: Pennsylvania State University Press, 2007 ), p. 457

${ }^{353}$ William Taubman, Khrushchev: The Man and His Era (London: Simon \& Schuster, 2005), p. 392
} 
on its pledge to assist the PRC in its nuclear program, ${ }^{354}$ but after yet another disastrous visit to Beijing, Khrushchev began to recall Soviet technical advisers and reduced economic aid to the PRC by $1960 .{ }^{355}$ These events caused significant disarray to major ongoing economic and technical projects within China ${ }^{356}$ However, notwithstanding the clear reason for these decisions, the official rhetoric from the USSR focused on the poor treatment of its technicians in China as the cause for their withdrawal. ${ }^{357}$ The end of Soviet technical assistance and aid set the stage for the subject of the unequal treaties to resurface and become a central topic of discussion between the erstwhile allies.

Like the series of events that led to the Sino-Soviet split, the re-emergence of the issue of unequal treaties began with direct and indirect rhetorical exchanges between Mao and Khrushchev. Disagreements regarding the events of the Cuban Missile Crisis and its resolution created yet another rift in the Communist camp. The official position of the USSR was that the withdrawal of missiles from Cuba in exchange for American guarantees of not invading the island not only ensured peace, but also safeguarded Cuban independence and sovereignty. ${ }^{358}$ Mao interpreted the events very differently and

\footnotetext{
${ }^{354}$ Ibid. p. 392-393

${ }^{355}$ Mark Kramer, "The Soviet Ministry Appraisal of Sino-Soviet Relations on the Eve of the Split," in The Cold War in Asia, Cold War International History Project Bulletin 6-7, 1995/1996, p. 177

${ }^{356}$ Ibid.

${ }^{357}$ See: "Letter, Khrushchev to the Central Committee of the Socialist Unity Party of Germany, Regarding Soviet Specialists in China," The Wilson Center Digital Archive, July 18, 1960, http://digitalarchive.wilsoncenter.org/document/116831; "Note, The Soviet Embassy in Beijing to the Ministry of Foreign Affairs of the People's Republic of China," The Wilson Center Digital Archive, July 18, 1960, http://digitalarchive.wilsoncenter.org/document/117052

${ }^{358}$ Alfred D. Low, The Sino-Soviet Dispute: An Analysis of the Polemics (London: Associated University Presses, 1976), p. 130-131
} 
contended that Khrushchev's policies had amounted to adventurism followed by capitulationism. ${ }^{359}$ Khrushchev would respond during a speech in the Supreme Soviet in 1962 contending that while China advocated for more provocation against the United States during the Cuban Missile Crisis, it had effectively tolerated British and Portuguese control of Hong Kong and Macau respectively. ${ }^{360} \mathrm{He}$ argued that the CCP was more capitulationist than he was since the PRC had allowed imperialist powers to maintain "foulsmelling" colonies right on its doorstep. ${ }^{361}$ This sentiment was echoed by the Communist Party of the United States in a statement criticizing the CCP for "not following the adventurous policy in Taiwan, Hong Kong and Macau" that it had advocated in the Caribbean. ${ }^{362}$

Mao and the CCP responded with a series of articles published in the People's Daily and Red Flag. The seventh article, the last and most critical, titled "A Comment on the Statement of the Communist Party of the U.S.A." formally raised the question of the unequal treaties. ${ }^{363}$ While the article never mentions Khrushchev directly, it is implicit that this article is addressed to him and his statements over Hong Kong and Macau. The article stated that

\footnotetext{
${ }^{359}$ William Taubman, Khrushchev: The Man and His Era (London: Simon \& Schuster, 2005), p. 578

${ }^{360}$ Chi-Kwan Mark, The Everyday Cold War: Britain and China, 1950-1972 (London: Bloomsbury Publishing PLC, 2017), p. 90

${ }^{361}$ Michael R. Beschloss, The Crisis Years: Kennedy and Khrushchev, 1960-1963 (New York: HarperCollins Publishers, 1991)

${ }^{362}$ Chi-Kwan Mark, The Everyday Cold War: Britain and China, 1950-1972 (London: Bloomsbury Publishing PLC, 2017), p. 90

363 Ibid.
} 
"In the hundred years or so prior to the victory of the Chinese revolution, the imperialist and colonial powers - the United States, Britain, France, Tsarist Russia, Germany, Japan, Italy, Austria, Belgium, the Netherlands, Spain and Portugal - carried out unbridled aggression against China. They compelled the governments of old China to sign a large number of unequal treaties - the Treaty of Nanking of 1842, the Treaty of Aigun of 1858, the Treaty of Tientsin of 1858, the Treaty of Peking of 1860, the Treaty of Ili of 1881, the Protocol of Lisbon of 1887, the Treaty of Shimonoseki of 1895, the Convention for the Extension of Hong Kong of 1898, the International Protocol of 1901, etc. By virtue of these unequal treaties, they annexed Chinese territory." ${ }^{364}$

Additionally, the article contended that since its establishment in 1949, the PRC had sought to examine the treaties signed by previous governments and "would recognize, abrogate, revise or renegotiate them according to their respective contents." 365 Negotiations, it argued, would be conducted peacefully and that pending a settlement, the status quo would be maintained. ${ }^{366}$ More importantly, however, the article took direct aim at Khrushchev's comments on Hong Kong and Macau and raised the question of Russia's complicit role in China's century of humiliation by stating

"You are not unaware that such questions as those of Hong Kong and Macao relate to the category of unequal treaties left over by history, treaties which the imperialists imposed on China. It may be asked: In raising questions of this kind, do you intend to raise all the questions of the unequal treaties and have a general settlement? Has it ever entered your heads what the consequences would be? Can you seriously believe that this will do you any good?"367

It was here, in the midst of the Sino-Soviet split, that the issue of unequal treaties reemerged in Sino-Soviet relations. The USSR and the PRC would end diplomatic relations in 1962 and would undertake a series of clashes along their shared border throughout the

\footnotetext{
364 "A Comment on the Statement of the Communist Party of the U.S.A." People's Daily, March 8, 1963, p. 12, http://www.marx2mao.com/Other/CCP2CPUSA63.pdf

365 Ibid.

366 Ibid.

${ }^{367}$ Ibid. p. 14
} 
decade, culminating in the Zhenbao Island Incident on March $2 \& 15,1969 .{ }^{368}$ This would be the closest the two countries would ever come to open hostilities and war. ${ }^{369}$ It would take a rapprochement between the two sides in the mid-1980s to begin negotiations for demarcating their shared border.

\section{$\underline{\text { Rapprochement and Border Settlements }}$}

On July 28, 1986, Mikhail Gorbachev gave a speech in Vladivostok that opened the door for rapprochement between the USSR and the PRC. In this speech, Gorbachev, now the General Secretary of the CPSU, reflected that the two counties shared the world's longest land border and that they were destined to live near each other forever and ever. ${ }^{370}$ Gorbachev indicated that relations between the USSR and the PRC had improved in recent years, and affirmed that "the Soviet Union is prepared - any time, at any level - to discuss with China questions of additional measures for creating an atmosphere of goodneighborliness. We hope that the border dividing - I would prefer to say, linking - us will soon become a line of peace and friendship." ${ }^{371}$ Additionally, Gorbachev spoke about the desire to reduce troop deployments along the Sino-Soviet border, contending that the USSR

\footnotetext{
${ }^{368}$ See: "Soviet Report to East German Leadership on Sino-Soviet Border Clashes," The Wilson Center Digital Archive, March 2, 1969, http://digitalarchive.wilsoncenter.org/document/116975; Guihua Yang, "Treasure Island Self-Defense Counterattack in 1969," People, July 4, 2002, http://www.people.com.cn/GB/junshi/192/8559/8564/20020704/768476.html

${ }^{369}$ Yang Kuisong, "The Sino-Soviet Border Clash of 1969: From Zhenbao Island to Sino-American Rapprochement," Cold War History 1(1), 2000, p. 21-52

${ }^{370}$ Mikhail Sergeevich Gorbachev, "Speech by Mikhail Gorbachev in Vladivostok, July 28, 1986," Novotsi Press Agency Pub. House, July 28, 1986, https://searchworks.stanford.edu/view/1921110

${ }^{371}$ Ibid.
} 
was prepared to discuss concrete steps with the PRC "aimed at a balanced lowering of the level of land forces." 372 While relations between the PRC and the USSR had improved during the early 1980s, Gorbachev's speech was a landmark moment that galvanized the rapprochement between the two countries and opened the door for the settlement of their long-standing border dispute.

\section{Negotiating the Eastern Boundary}

Although numerous efforts had been made to negotiate the Sino-Soviet border in the 1960s and 1970s, these efforts proved fruitless due to the ideological and political split of the two countries. However, in 1986 Gorbachev agreed to accept the Chinese precondition for negotiating their eastern border, thus allowing the process to move forward. The PRC took the position that the negotiations needed to be based on the renegotiation of the Treaty of Peking (1860), an unequal treaty, and specifically the modifications made to the treaty by Peter Kozakevich, a chief Russian boundary commissioner, in $1861 .^{373}$ The Treaty of Peking was problematic not only because it cemented the territorial gains made by the Russian Empire under the Treaty of Aigun (1858), a total of 600,000 square kilometers north of the Amur river, but also because it added over 400,000 square kilometers east of the Ussuri river (see map 4). ${ }^{374}$ Nevertheless,

\footnotetext{
${ }^{372}$ Ibid. p. 36

${ }^{373}$ Neville Maxwell, "How the Sino-Russian Boundary Conflict was finally Settled," Critical Asian Studies $39(2), 2007)$, p. 232, 241, 250

374 "Statement of the Government of the People's Republic of China," Peking Review 12(22), May 24, 1969, p. $4-5$
} 
although the issue of territorial cessions was sporadically raised by the PRC during the Sino-Soviet split, the real motivation for using the Treaty of Peking as the basis of negotiation rested on the modifications made by Kozakevich in 1861. The Treaty of Peking implicitly treated the Amur and Ussuri rivers as Boundary Rivers, and therefore, shared international waterways. However, the map which Peter Kozakevich drew, and coerced his counterparts from the Qing court to accept, made the waterways exclusively Russian by making the Chinese banks the international boundary. ${ }^{375}$

This issue was at the core of the clashes that took place on the eastern part of the border throughout the Sino-Soviet split in the 1960s since the PRC contested the USSR's continued adherence to Kozakevich's map and its claims to the islands that dotted the two rivers. The Soviet adherence to the China-bank boundary, based on Kozakevich's cartographic modification to the Treaty of Peking, was dismissed by the PRC. Beijing contended that since the map was 1:1,000,000 scale it could not possibly show the precise location of the boundary in the river, much less address the issue of sovereignty over the disputed islands. ${ }^{376}$ Instead, the PRC rested its legal case on the wording of the Treaty of Peking and the thalweg principle of international law. ${ }^{377}$

Thalweg, a German word meaning deepest channel, has its origins in international law dating back to the Peace of Westphalia (1648). This principle is used to address the

\footnotetext{
375 Neville Maxwell, "How the Sino-Russian Boundary Conflict was finally Settled," Critical Asian Studies 39(2), 2007), p. 232

376 "Statement of the Government of the People's Republic of China," Peking Review 12(22), May 24, 1969 , p. 3

${ }^{377}$ Neville Maxwell, "How the Sino-Russian Boundary Conflict was finally Settled," Critical Asian Studies 39(2), 2007), p. 240
} 
boundary-at-the-banks type of river boundaries ${ }^{378}$ and has become the main criterion for the demarcation of river boundaries in Africa, Asia, and the Americas. ${ }^{379}$ The thalweg principle sets the boundary at the deepest part of the river, although in some conventions the boundary has been set following the main navigable channel or the median line of the main navigable channel. ${ }^{380}$ This is important since the Amur and Ussuri rivers are both navigable and using the thalweg principle would not only make both countries co-owners of the rivers, giving them equal rights to their use, but would also allow for a more equitable settlement of the sovereignty of the hundreds of islands that dot both of these waterways. ${ }^{381}$ Consequently, by pursuing negotiations based on the wording of the Treaty of Peking as well as established principles in international law, the PRC remained consistent with its aim to "recognize, abrogate, revise or renegotiate [treaties] according to their respective contents" through peaceful negotiations ${ }^{382}$ and, more importantly, in harmony with international law. In other words, rather than take an irredentist position in its land border negotiations, the PRC was acting within the bounds of international law and customs. This is important since by declaring that it was observing international law, the PRC was

\footnotetext{
${ }^{378}$ Dante Caponera, Principles of Water Law and Administration: National and International $2^{\text {nd }}$ Edition (Leiden: Taylor \& Francis/Balkema, 2007), p. 203 ( $2^{\text {nd }}$ edition revised and updated by Marcella Nanni)

379 Ibid. p. 207

380 Ibid.

${ }^{381}$ Neville Maxwell, "How the Sino-Russian Boundary Conflict was finally Settled," Critical Asian Studies 39(2), 2007), p. 240

382 “A Comment on the Statement of the Communist Party of the U.S.A." People's Daily, March 8, 1963, p. 12, http://www.marx2mao.com/Other/CCP2CPUSA63.pdf
} 
pressuring the USSR to adhere to internationally recognized principles while simultaneously creating a positive influence on the international community. ${ }^{383}$

After decades of maintaining a position of "exclusive right of possession and sovereign jurisdiction" over the border rivers, ${ }^{384}$ the Soviet leadership, through Gorbachev in his Vladivostok speech, finally accepted the Chinese precondition for negotiations. By stating that the "official border could pass along the main ship channel," Gorbachev was accepting the thalweg principle of international law, thus paving the way for negotiations to resume. ${ }^{385}$ This was no easy concession since this meant that the USSR would be relinquishing its claims to hundreds of islands. More importantly, by adhering to the thalweg principle, Zhenbao Island over which much blood was shed in the 1960s, would fall squarely within Chinese territory. ${ }^{386}$ However, sovereignty of the crown jewel in the dispute, Heixiazi/Bear Island, located at the confluence of the Amur and Ussuri rivers, remained non-negotiable for the Soviet side. It is here that the Chinese made a critical modification to the negotiation process: When an intractable issue regarding a particular area arose, and all effort to resolve it had failed, it should be set aside and not allowed to halt or sour negotiations in other areas. ${ }^{387}$ In 1987 , negotiations to settle the Sino-Soviet

\footnotetext{
383 Junwu Pan, Toward a Framework for Peaceful Settlement of China's Territorial and Boundary Disputes (Leiden: Martinus Nijhoff Publishers, 2009), p. 97-98

${ }^{384}$ Neville Maxwell, "How the Sino-Russian Boundary Conflict was finally Settled," Critical Asian Studies 39(2), 2007), p. 250

${ }^{385}$ Mikhail Sergeevich Gorbachev, "Speech by Mikhail Gorbachev in Vladivostok, July 28, 1986," Novotsi Press Agency Pub. House, July 28, 1986, https://searchworks.stanford.edu/view/1921110

${ }^{386}$ Neville Maxwell, "How the Sino-Russian Boundary Conflict was finally Settled," Critical Asian Studies 39(2), 2007), p. 251

${ }^{387}$ Ibid.
} 
border resumed at the deputy foreign ministry level. By 1988, working groups convened in order to examine the exact location of the boundary line along the entire 4,200 kilometer eastern border. ${ }^{388}$ Furthermore, after Gorbachev's official visit to Beijing in 1989, the SinoSoviet rapprochement had reached a high point, consequently, negotiations accelerated. ${ }^{389}$

On May 16, 1991, the "Agreement on the Eastern Section of the Boundary between the People's Republic of China and the Union of Soviet Socialist Republics," was signed. ${ }^{390}$ Although nationalism and local discontent on both sides of the border, but more strongly on the Russian side, posed key challenges for settling a number of sections along the boundary throughout the 1990s, leaders of the Russian Federation, the successor state to the USSR, understood what was at stake in the negotiation. There was particular concern that caving in to nationalist pressure would push the Chinese delegation to question the legality of the nearly 1,500,000 square kilometer area that was ceded to the Russian Empire as a result of unequal treaties, which under international law, could be legally considered void and null. More importantly, however, the Russians feared that going against the agreed upon principles of the 1991 agreement for demarcating the boundary would harm their international prestige. This sentiment was expressed in a 1996 speech given by Boris Nikolayevich Yeltsin, President of the Russian Federation (1991-1999), at Khabarovsk, a

\footnotetext{
${ }^{388}$ George Ginsburgs, From Soviet to Russian International Law: Studies in Continuity and Change (The Hague: Kluwer Law International, 1998), p. 251

${ }^{389}$ Iwashita Akihiro, A 4,000 Kilometer Journey Along the Sino-Russian Border (Sapporo: Slavic Research Center, Hokkaido University, 2004), p. 10

${ }^{390}$ Eric Hyer, “The Sino-Russian Boundary Settlement," IBRU Boundary and Security Bulletin, $1996, \mathrm{p}$. 92, https://www.dur.ac.uk/resources/ibru/publications/full/bsb4-2_hyer.pdf
} 
city on the banks of the Ussuri River and across from the contested Heixiazi/Bear Island. In this speech, Yeltsin indicated that "for the first time in the 300-year-long history of relations with China, we have a legally adjusted border which is almost completely registered." ${ }^{391}$ Additionally, Yeltsin reminded the local leaders at Khabarovsk that in the past, the PRC had advanced demands for the 1,500,000 square kilometers that were ceded as part of unequal treaties. Finally, while recognizing that leaders across the eastern border were opposed to the cession of land to the PRC based on the thalweg principle, Yeltsin argued that "international obligations must be fulfilled," and that Russian inability to settle the border along two small areas would threaten the demarcation of the 4,000 kilometer long Sino-Russian border. ${ }^{392}$

Ultimately, treaties based on principles of international law, and not nationalism, prevailed. ${ }^{393}$ By 1999 the two sides had set up 1183 boundary markers, leaving only two small sections of the border unsettled. ${ }^{394}$ Those areas were settled in a 2004 agreement. Through the 1991 agreement the PRC acquired 52\% of the islands in the Amur and Ussuri River. ${ }^{395}$ However, through this settlement, the PRC formally relinquished claims to nearly $1,500,000$ square kilometers of territory which it was forced to cede as part of the unequal treaties it signed with the Russian Empire in the $19^{\text {th }}$ century.

\footnotetext{
${ }^{391}$ Ibid. 93

${ }^{392}$ Ibid.

${ }^{393}$ Junwu Pan, Toward a Framework for Peaceful Settlement of China's Territorial and Boundary Disputes (Leiden: Martinus Nijhoff Publishers, 2009), p. 97

${ }^{394}$ Rongxin Guo, Cross-Border Resource Management, Volume $102^{\text {nd }}$ Edition (Elsevier, 2012), p. 214

${ }^{395}$ M. Taylor Fravel, "Regime Insecurity and International Cooperation: Explaining China's Compromises in Territorial Disputes," International Security 30(2), 2005, p. 56
} 
China-USSR Border: Eastern Sector
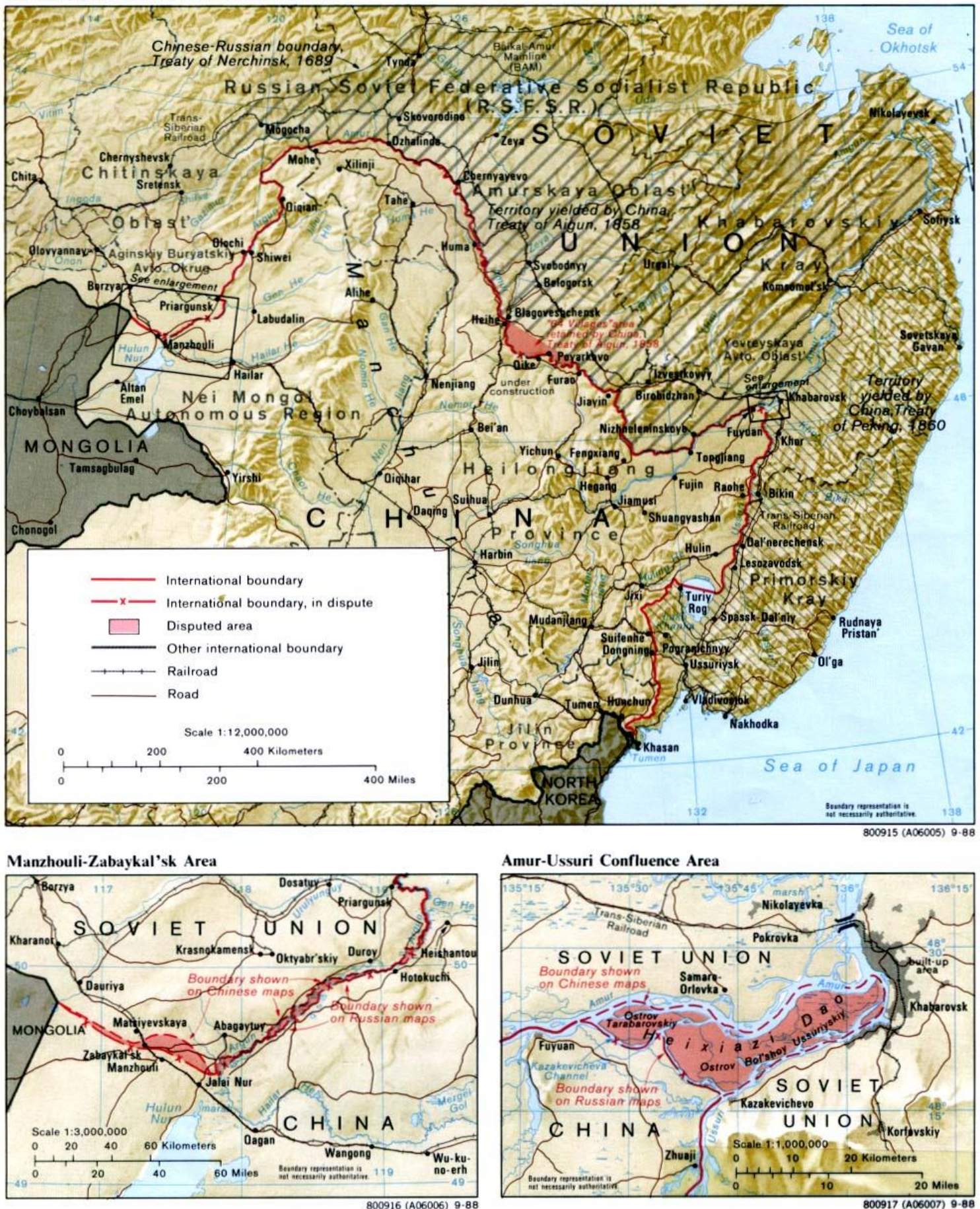

Map 4: Eastern territory ceded by the Qing through unequal treaties. Source:

https://legacy.lib.utexas.edu/maps/middle_east_and_asia/china_ussr_e_88.jpg 


\section{Negotiating the Western Boundary}

There were many parallels between the western and eastern sections of the border. The first was that both sections were primarily defined by unequal treaties, particularly the treaties of Peking (1860) and Ili (1881). Through the Treaty of Peking and the Tarbagatai Agreement (1864), a border protocol that demarcated the border using the former as the basis, the Qing Empire lost 440,000 square kilometers along its western frontier. ${ }^{396}$ Furthermore, through the Treaty of Ili (1881), sometimes known as the Treaty of St. Petersburg, the empire lost an additional 70,000 square kilometers in the Ili valley region. ${ }^{397}$ Lastly, in violation of the "Protocol on the Sino-Russian Boundary in the Kashgar Region" (1884), the Russian Empire occupied over 20,000 square kilometers of Qing territory in the Pamir Mountain range (see map 5). ${ }^{398}$ This would become a serious point of contention between the PRC and Tajikistan which inherited the contested Pamir section upon its independence.

The second similarity between the western and eastern sections of the border was that both parties fought a number of skirmishes during the Sino-Soviet split. While the Zhenbao Incident is the most well-known skirmish of the Sino-Soviet split, ${ }^{399}$ the events that occurred along the western border during this period posed a far greater threat to the territorial integrity of the PRC. This was due to the fact that while both sections of the

\footnotetext{
${ }^{396}$ Iwashita Akihiro, A 4,000 Kilometer Journey Along the Sino-Russian Border (Sapporo: Slavic Research Center, Hokkaido University, 2004), p. 178

${ }^{397}$ Ibid.

398 "Chinese and Soviet Statements on the Frontier Question," Keesing's Record of World Events 15, 1969, http://web.stanford.edu/group/tomzgroup/pmwiki/uploads/0349-1969-11-K-c-EYJ.pdf

399 Yang Kuisong, "The Sino-Soviet Border Clash of 1969: From Zhenbao Island to Sino-American Rapprochement," Cold War History 1(1), 2000, p. 21-52
} 
border were contested, the Russians possessed greater influence on China's western frontier as a result of greater economic exchange, weak Chinese central authority in the region throughout the $19^{\text {th }}$ and early $20^{\text {th }}$ century, and the lack of another foreign challenger as was the case with Japan in Manchuria.

In 1884, a few years after the Dungan Rebellion (1862-1877) was put down, the Qing formally upgraded its western territories from military rule to civilian administration under the province of Xinjiang (New Frontier). ${ }^{400}$ Despite the end of the rebellion, however, the new province would remain a source of unrest for decades to come. On at least two occasions in the $20^{\text {th }}$ century, the province declared independence and established itself as the East Turkestan Republic. More problematic for the PRC, however, was the fact that the USSR, like the Russian Empire before it, remained actively involved in the political and economic affairs of Xinjiang.

Throughout the republican period (1912-1949), the weakened position of the ROC's central government turned Xinjiang into a borderline Soviet satellite. The USSR not only deployed forces in Xinjiang to assist the pro-Soviet administrations of Jin Shuren and Sheng Shicai against ROC forces, ${ }^{401}$ but also continued to foment dissent and proactively assist separatist movements within the province after its incorporation into the PRC. At the height of the Sino-Soviet split, the USSR used the exodus of Uyghurs,

\footnotetext{
${ }^{400}$ Peter C. Perdue, China Marches West: The Qing Conquest of Central Eurasia (Massachusetts: The Belknap Press of Harvard University Press, 2005), p. 33, 320-321

${ }^{401}$ See: Andrew D.W. Forbes, Warlords and Muslims in Chinese Central Asia: A Political History of Republican Sinkiang 1911-1949 (Cambridge: Cambridge University Press, 1986), p. 116-127; James A. Millward and Nabijan Tursun, "Political History and Strategies of Control, 1884-1978, in Xinjiang as China's Muslim Borderland, ed. S. Fredrick Starr (Armonk: M.E. Sharpe, 2004), p. 79-81
} 
Kazakhs, Tajiks, and Kyrgyz into its Kazakh SSR in 1962 as part of a comprehensive propaganda campaign to undermine PRC legitimacy in Xinjiang. ${ }^{402}$ The PRC responded to Soviet propaganda with an official statement claiming that leaders in the CPSU and their agents in Xinjiang had enticed or coerced several tens of thousands of Chinese citizens to go to the USSR and that, despite repeated requests to repatriate them, the Soviet Union refused to do so under the pretext of "Soviet legality" and "humanitarianism." "403 Adding fuel to the fire, during an interview with a Japanese parliamentary delegation on September 20, 1964, Khrushchev personally questioned the legitimacy of China's claim not only to Xinjiang, but also to Tibet and Mongolia. ${ }^{404}$ In response, Mao arranged for Saifuddin Azizi, Chairman of Xinjiang at the time, to make a radio address on October 1, 1964, which warned Khrushchev and his revisionists that any attempts to invade or occupy Chinese territory would be repulsed by the various nationalities within Xinjiang as well as the 650 million-strong Han population. ${ }^{405}$

However, the threat to territorial integrity was not merely rhetorical. While Soviet propaganda in support of subversive activities in Xinjiang was problematic, there was also the present danger of clashes with Soviet forces along the border, and more importantly,

\footnotetext{
402 See George Moseley, A Sino-Soviet Cultural Frontier: The Ili Kazakh Autonomous Chou (Cambridge: Harvard University Press, 1966), p. 109-110; Tai-Sung An, The Sino-Soviet Territorial Dispute (Philadelphia: The Westminster Press, 1973), p. 85

403 "The Origin and Development of the Differences Between the Leadership of the CPSU and Ourselves: Comment on the Open Letter of the Central Committee of the CPSU," Foreign Language Press, 1963, https://www.marxists.org/subject/china/documents/polemic/cpsu.htm\#origin

${ }^{404}$ Nikita Sergeyevich Khrushchev, Pravda, September 20, 1964, translated in The Current Digest of the Soviet Press 16(38), October 14, 1964, p. 3-7

405 Dennis J. Doolin, Territorial Claims and the Sino-Soviet Conflict: Documents and Analysis (Stanford: The Hoover Institution, 1965), p. 76
} 
with Soviet-supported refugee guerrillas. These guerrillas were formed by the Muslim minority groups that had fled Xinjiang during the Great Leap Forward, and regularly conducted raids against Chinese border posts. ${ }^{406}$ The PRC reported that in 1966 alone, over 5,000 raids were conducted by these Soviet-backed guerrillas into Xinjiang. ${ }^{407}$ These clashes climaxed, as they had in the eastern border, in 1969 when a Chinese patrol engaged in a skirmish with Soviet border forces on August 13 in the Tielieketi region near Lake Zhalanashkol. This confrontation resulted in the deaths of 25 Chinese border patrolmen and 3 regular soldiers, ${ }^{408}$ and like the Zhenbao Incident in March that year, raised the specter of war between the two countries. ${ }^{409}$ Furthermore, the contested Tielieketi region remained Soviet territory and was transferred to Kazakhstan after independence. However, after the border settlement between the two countries in the 1990s, this region would be returned to China.

Negotiations on the western section of the border began in 1988 after consensus was reached on the delineation of the majority of the eastern section. ${ }^{410}$ In essence, the two sections were being negotiated simultaneously as part of the same agreement, although the delineation of the eastern boundary had progressed at a quicker rate than the western portion. As with the eastern section, the PRC relied on the text of the unequal treaties as

\footnotetext{
${ }^{406}$ Tai-Sung An, The Sino-Soviet Territorial Dispute (Philadelphia: The Westminster Press, 1973), p. 85

${ }^{407}$ Ibid.

${ }^{408}$ Jinzhou Xu, “Analysis of 1969's "Order Number One," in Selected Essays on the History of Contemporary China, ed. Xingxing Zhang (Leiden: Brill, 2015), p. 172

${ }^{409}$ Benjamin Lai, The Dragon's Teeth: The Chinese People's Liberation Army - Its History, Traditions, and Air, Sea, and Land Capabilities in the $21^{\text {st }}$ Century (Havertown: Casemate Publishers, 2016)

${ }^{410}$ George Ginsburgs, From Soviet to Russian International Law: Studies in Continuity and Change (The Hague: Kluwer Law International, 1998), p. 251
} 
the basis of negotiations in the western section. More importantly, the PRC did not use the unequal treaties as a platform to make irredentist claims over the vast tracts of land that the Qing had lost in the $19^{\text {th }}$ century. Rather, the purpose was to use the existing border defined by these treaties as the starting point for negotiating contested sections along the border. This meant that the contested space was relatively minor in proportion to what was actually lost under the unequal treaties.

However, what had begun as a single-package border negotiation of the entire SinoSoviet border ended on December 25, 1991 when Gorbachev resigned and the Soviet Union ceased to exist. While the majority of the eastern boundary had been settled by 1991 , the collapse of the USSR resulted in the independence of Kazakhstan, Kyrgyzstan, and Tajikistan, thus complicating the negotiation process. The collapse of the USSR divided the western border into four sections: a 50 kilometer Sino-Russian border, a 1,700 kilometer Sino-Kazakh border, a 1,000 kilometer Sino-Kyrgyz border, and finally, a 430 kilometer Sino-Tajik border. ${ }^{411}$ Further complicating this development was the fact that immediately after their independence, the three Central Asian republics did not recognize existing territorial disputes with the PRC and did not want to join border negotiations. However, after mediation by the Russian Federation, they collectively formed the "Four plus One" negotiation formula which would follow the spirit of the agreements already signed between the USSR and the PRC. ${ }^{412}$ Under this formula, the Russian Federation and the three Central Asian republics would negotiate as a single entity in order to improve the

\footnotetext{
${ }^{411}$ Iwashita Akihiro, A 4,000 Kilometer Journey Along the Sino-Russian Border (Sapporo: Slavic Research Center, Hokkaido University, 2004), p. 178

412 Ibid. p. 179
} 
leverage of the smaller states in negotiations with the PRC. ${ }^{413}$ However, by the second half of the 1990s the delegations separated as each republic concluded independent agreements with the PRC..$^{414}$

The first agreement on the western section of the border was reached with the Russian Federation in 1994. After the collapse of the USSR, the Sino-Russian border had been substantially reduced to a 50 kilometer stretch which met at a tri-border of the PRC, Mongolia, and the Russian Federation. In order to reach an agreement for this small tract of border, the two sides settled on the high watershed principle of international law. A watershed is defined as an "area of land in which all of the incoming precipitation drains (i.e., "sheds") to the same place - toward the same body of water or the same topographic low area (e.g., a sinkhole) - as a result of its topography." ${ }^{415}$ As a result, a "watershed's boundary is defined by its topographic high points," thus the boundaries are defined by the ridges. ${ }^{416}$ The PRC had already made use of this principle for previous border negotiations, such as in the Sino-Nepal Boundary Agreement (1960), and the Sino-Burmese Border Treaty (1961). ${ }^{417}$ In other words, the PRC had already established a precedent for negotiating under the rubric of existing norms in international law. This not only helped to

\footnotetext{
${ }^{413}$ George Ginsburgs, From Soviet to Russian International Law: Studies in Continuity and Change (The Hague: Kluwer Law International, 1998), p. 301

${ }^{414}$ Neville Maxwell, "How the Sino-Russian Boundary Conflict was finally Settled," Critical Asian Studies 39(2), 2007), p. 252

${ }^{415}$ Pamela J. Edwards, Karl J.W. Williard, and Jon E. Schoonover, "Fundamental of Watershed Hydrology," Journal of Contemporary Water Research \& Education 154(1), 2015, p. 3-4

${ }^{416}$ Ibid.

${ }^{417}$ Dinesh Mathur, "Chinese Perceptions of Various Territorial Disputes,” CLAWS Journal, 2008, p. 136137
} 
strengthen China's claims and position, but also to moderate them. ${ }^{418}$ Beyond the benefits of negotiating under an established principle in international law, there was also a pragmatic dimension to opting to settle the border using the high watershed principle. The Altay Mountains shared between the two presented a very clear watershed, thus facilitating negotiations. ${ }^{419}$ Consequently, an agreement on the delineation of the western section of the Sino-Russian border was reached in 1994 and was formally demarcated with two markers in $1998 .{ }^{420}$

Negotiations with the three Central Asian republics along the western section would be more complex since the border was significantly longer, and the fact that initially, as stated above, the republics had refused to acknowledge a territorial dispute with the PRC. Nevertheless, once negotiations resumed, the parties opted to pursue a "fifty-fifty" approach for partitioning contested sections of their borders. However, the final agreements do not reflect a fifty-fifty split, in fact the PRC conceded the greater share of territory in bilateral negotiations with each of the three Central Asian Republics. ${ }^{421}$ The quickest of the negotiations occurred with Kazakhstan. Almost simultaneously with the Sino-Russian agreement on the western section, the PRC and Kazakhstan reached an initial agreement

\footnotetext{
${ }^{418}$ Junwu Pan, Toward a Framework for Peaceful Settlement of China's Territorial and Boundary Disputes (Leiden: Martinus Nijhoff Publishers, 2009), p. 98

419 Tadeusz Dmochowski, "The Settlement of the Russian-Chinese Border Dispute," Polish Political Science Yearbook 44, 2015, p. 68-69

${ }^{420}$ Ibid.

${ }^{421}$ Iwashita Akihiro, "An Inquiry for New Thinking on the Border Dispute: Backgrounds of "Historic Success" for the Sino-Russian Negotiations," in Siberia and the Russian Far East in the 21 ${ }^{\text {st }}$ Century: Partners in the "Community of Asia", ed. Iwashita Akihiro (Sapporo: Slavic Research Center, Hokkaido University, 2005), p. 107-110
} 
in 1994, ${ }^{422}$ and following additional agreements in 1997 and 1998, the Sino-Kazakh border was effectively demarcated. ${ }^{423}$ Of the contested sections of their shared border, the PRC settled for 940 square kilometers, or roughly $44 \% .{ }^{424}$ As part of these negotiations Kazakhstan returned the region of Tielieketi, the site of the bloodiest skirmish of the SinoSoviet split, to the PRC. ${ }^{425}$

The borders with Kyrgyzstan and Tajikistan were delineated through agreements in 1996 and 1999 respectively, ${ }^{426}$ although a supplementary agreement with Kyrgyzstan was finalized in $1999^{427}$ and another one was reached with Tajikistan in $2011 .{ }^{428}$ In the Sino-Kyrgyz agreement, the PRC settled for 950 square kilometers which translated to $30 \%$ of contested territory. ${ }^{429}$ The Sino-Tajik negotiations were the most difficult. In essence,

\footnotetext{
${ }^{422}$ Iwashita Akihiro, "The Shanghai Cooperation Organization and Its Implications for Eurasian Security: A New Dimension of 'Partnership' after the Post-Cold War Period," in Slavic Eurasia's Integration into the World Economy and Community, eds. Tabata Shinichiro and Iwashita Akihiro (Sapporo: Slavic Research Center, Hokkaido University, 2004), p. 263

423 "Delineation and Demarcation of State Border," Ministry of Foreign Affairs Republic of Kazakhstan, 1998, http://mfa.gov.kz/en/content-view/delimitatsiya-i-demarkatsiya-gosudarstvennoj-granitsy

${ }^{424}$ Iwashita Akihiro, "An Inquiry for New Thinking on the Border Dispute: Backgrounds of "Historic Success" for the Sino-Russian Negotiations," in Siberia and the Russian Far East in the $21^{\text {st }}$ Century: Partners in the "Community of Asia", ed. Iwashita Akihiro (Sapporo: Slavic Research Center, Hokkaido University, 2005), p. 107

425 "Agreement between the Republic of Kazakhstan and the People's Republic of China on the Kazakhstan-China international border, signed in Almaty on April 26, 1994," Ministry of Justice of the Republic of Kazakhstan, 1994, http://adilet.zan.kz/rus/docs/U950002331_\#z5 [Source in Russian]
}

426 "Agreement between the Kyrgyz Republic, People's Republic of China, and the Republic of Tajikistan on the Point of the Joint Frontiers of Three States," CIS-Legislation, 2000, http://cislegislation.com/document.fwx?rgn=4948

${ }^{427}$ Ibid.

${ }^{428}$ Alexander Sodiqov, "Tajikistan Cedes Disputed Land to China," Eurasia Daily Monitor 8(16), January 24, 2011, https://jamestown.org/program/tajikistan-cedes-disputed-land-to-china/

${ }^{429}$ Iwashita Akihiro, "An Inquiry for New Thinking on the Border Dispute: Backgrounds of "Historic Success" for the Sino-Russian Negotiations," in Siberia and the Russian Far East in the $21^{\text {st }}$ Century: 
the vast tracts of contested space in the Pamir Mountains constituted nearly one-seventh of the total territory of Tajikistan. ${ }^{430}$ Nevertheless, the two sides eventually came to an agreement in which the PRC settled for 1,000 square kilometers or 3.5\% of the contested territory. ${ }^{431}$ A key motivator for these concessions was the desire by the PRC to bring these neighbors into the fold to cooperate on important issues such as security and stability, especially along its western frontier. ${ }^{432}$ In other words, CCP officials, cognizant of historical events, understood that they needed their neighbors' cooperation in order for its state-building efforts to succeed.

As with the Sino-Russian cases, the agreements ignited significant local backlash in Central Asian communities. Many did not agree with making any territorial concessions to China. However, not only did the PRC settle for the smaller share of the contested sections of the boundary, but again, through these agreements Beijing was effectively giving up the vast majority of the territories lost under the unequal treaties. Thus, if evaluated from a historical perspective as well as the standards of international law, which would have invalidated these treaties outright, the PRC conducted negotiations in good will and respected the territorial integrity of its negotiating partners. This would pave the way for significant progress in confidence building, the demilitarization of their respective

Partners in the "Community of Asia”, ed. Iwashita Akihiro (Sapporo: Slavic Research Center, Hokkaido University, 2005), p. 107

${ }^{430}$ Iwashita Akihiro, "The Shanghai Cooperation Organization and Its Implications for Eurasian Security: A New Dimension of 'Partnership' after the Post-Cold War Period,' in Slavic Eurasia's Integration into the World Economy and Community, eds. Tabata Shinichiro and Iwashita Akihiro (Sapporo: Slavic Research Center, Hokkaido University, 2004), p. 263

${ }^{431}$ Ibid. p. 263-264

${ }^{432}$ M. Taylor Fravel, “Regime Insecurity and International Cooperation: Explaining China's Compromises in Territorial Disputes," International Security 30(2), 2005, p. 46-83 
borders, and ultimately, the normalization of relations between the PRC and its Eurasian neighbors. 
China-USSR Border

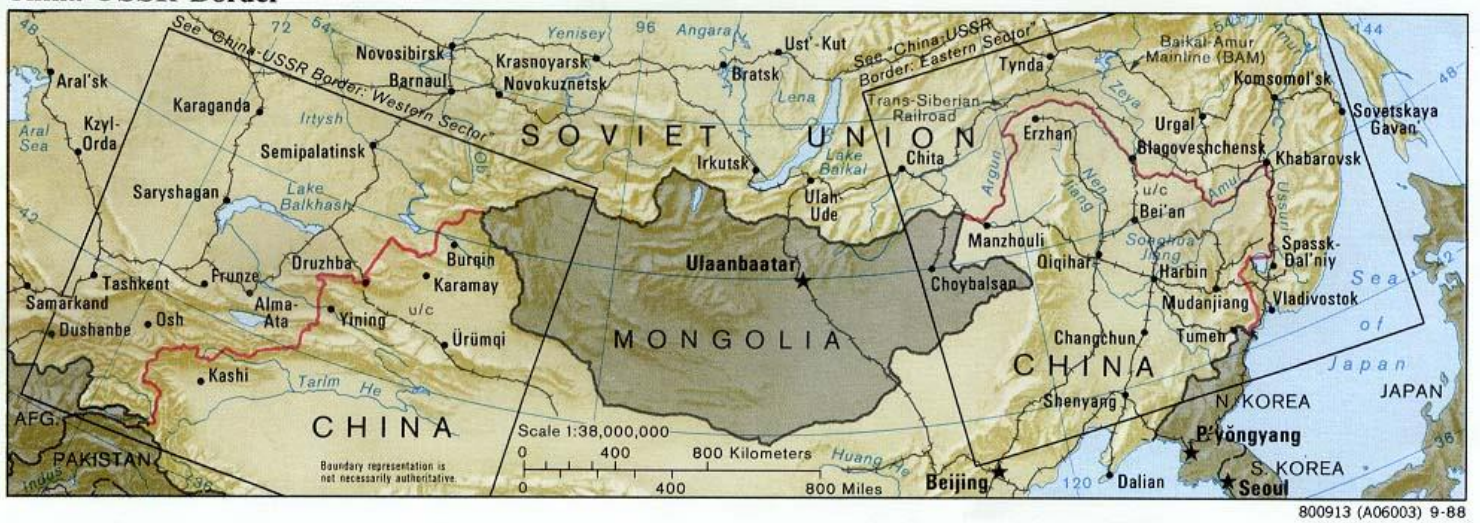

China-USSR Border: Western Sector

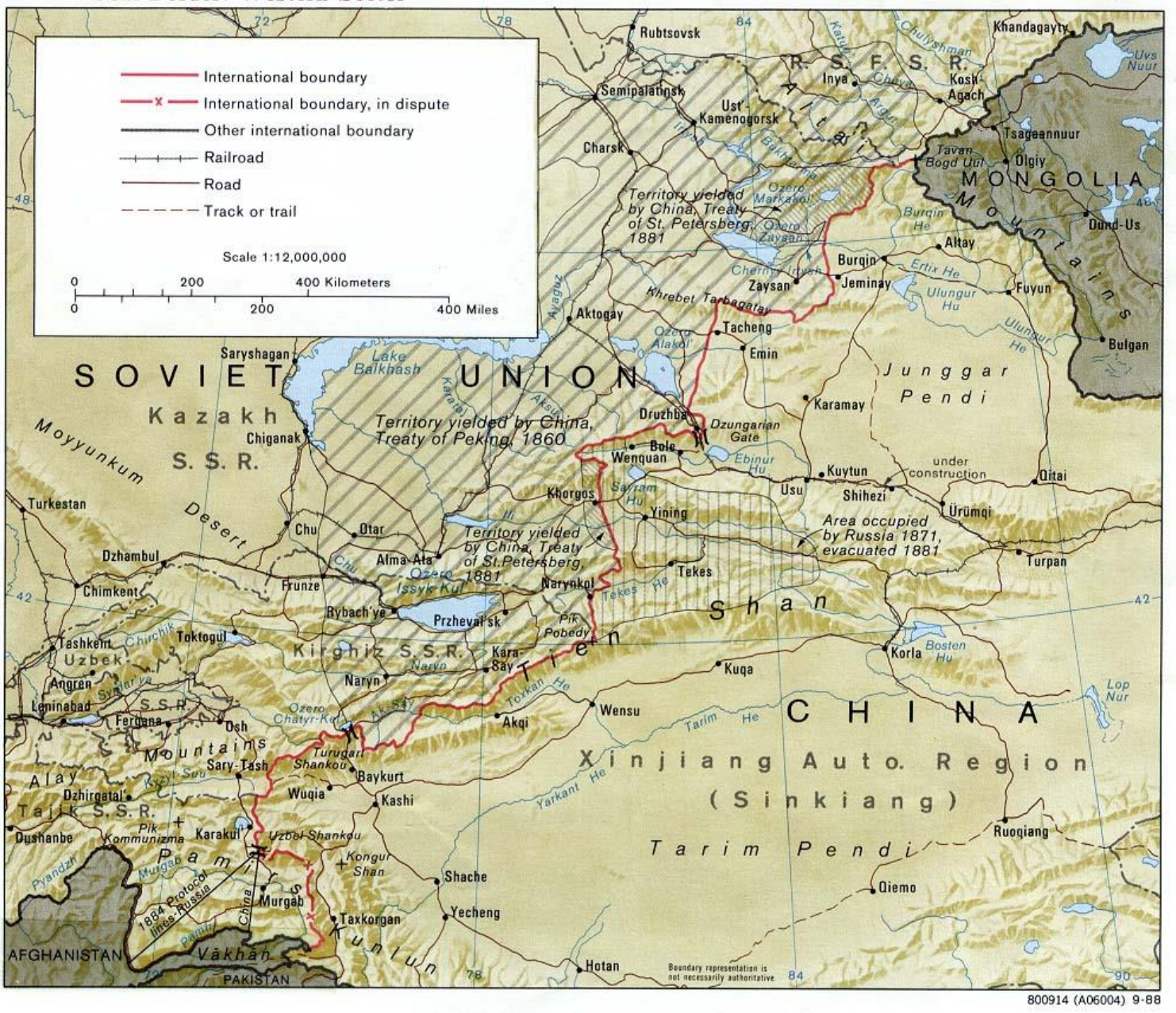

Map 5: Western territory ceded by the Qing through unequal treaties. Source:

https://legacy.lib.utexas.edu/maps/middle_east_and_asia/china_ussr_west88.jpg 


\section{Confidence-Building and Demilitarization}

An important point of concern between the PRC and the USSR at the start of border negotiations was the fact that the Sino-Soviet split had resulted in the significant deployment of forces by both sides along their shared border. As a result, the border had become heavily militarized. Although accurate numbers of the troop and equipment numbers are scarce, numerous reports throughout the Cold War provide some important insight. It is estimated that at the height of the Sino-Soviet split in 1969, both sides had each deployed 34 divisions with the majority of forces concentrated along China's northeastern region. ${ }^{433}$ By 1986, the beginning of the thaw in Sino-Soviet relations, the USSR had 53 divisions deployed along the border to face off the PRC's 68 divisions, which again, were primarily deployed along the eastern section of the border. ${ }^{434}$ These deployments reveal three important points despite the variation in deployment numbers across sources. The first is that the primary concentration of forces along China's northeastern regions indicates that despite the strategic importance of Xinjiang, the PRC was focused on the defense of Beijing and its industrial heartland in Manchuria. ${ }^{435}$ The second is that the Soviets maintained a qualitative advantage vis-à-vis the Chinese throughout the Cold War, and enjoyed far greater levels of mobility due to a significantly more robust infrastructure. ${ }^{436}$ The third, and perhaps most important, is the fact that much

\footnotetext{
${ }^{433}$ Yitzhak Shichor, "The Great Wall of Steel: Military and Strategy in Xinjiang," in Xinjiang: China's Muslim Borderland, ed. S. Fredrick Starr (Armonk: M.E. Sharpe, 2004), p. 134 
of the PRC's troop deployments were done in reaction to the USSR's own deployments along the border before the clashes of 1969 , and especially after these clashes took place. ${ }^{437}$ In fact, according to Gorbachev, the USSR had deployed roughly one million soldiers and a third of the country's missile forces to the border with the PRC during the height of the Sino-Soviet split. ${ }^{438}$

These conditions undermined efforts to establish confidence building mechanisms, and more importantly, move forward with border negotiations. It would not be until Gorbachev's visit to Beijing in the summer of 1989 that the two sides would discuss the possibility of reducing troop levels along the border regions. In order for this meeting to occur, however, Deng Xiaoping, China's paramount leader after the death of Mao Zedong, contended that the USSR had to address "three obstacles" hindering Sino-Soviet relations: “(1) the pullback of the Soviet military presence from the Chinese border, (2) the removal of Soviet forces from Mongolia, and (3) the cessation of Soviet support for Vietnam's occupation of Cambodia." ${ }^{439}$ By 1982, Deng added the Soviet invasion of Afghanistan to the list of the three obstacles and combined the first two into one. ${ }^{440}$

\footnotetext{
${ }^{437}$ See: Thomas W. Robinson, "The Sino-Soviet Border Dispute: Background, Development, and the March 1969 Clashes," American Political Science Review 66(4), 1972, p. 1185; Yitzhak Shichor, "The Great Wall of Steel: Military and Strategy in Xinjiang," in Xinjiang: China's Muslim Borderland, ed. S. Fredrick Starr (Armonk: M.E. Sharpe, 2004), p. 134

438 "Meeting between Mikhail Gorbachev and Deng Xiaoping (Excerpts)," The Wilson Center Digital Archive, May 16, 1989, http://digitalarchive.wilsoncenter.org/document/116536

439 Xiaoming Zhang, Deng Xiaoping's Long War: The Military Conflict between China and Vietnam, 1979. 1991 (Chapel Hill: The University of North Carolina, 2015), p. 195

440 Ibid.
} 
Here again, Gorbachev's Vladivostok's speech served as an official overture to the PRC by directly addressing Deng Xiaoping's preconditions for normalization. In the speech Gorbachev announced the withdrawal of Soviet forces from Afghanistan as well as the unilateral reduction of forces in Mongolia and the Far East that were deployed along the border with the PRC. However, he indicated that the resolution of the Vietnamese conflict could only be resolved through the normalization of relations between Beijing and Hanoi. ${ }^{441}$ This was enough for Deng Xiaoping to agree to meet Gorbachev at a summit in Beijing in 1989. In this meeting Deng Xiaoping and Mikhail Gorbachev agreed to normalize relations between the PRC and the USSR. Deng Xiaoping put forth a formula for future Sino-Soviet relations which not only reciprocated the spirit of Gorbachev's Vladivostok speech, but also allowed the Soviet leader to validate his efforts to pursue the demilitarization of the border. At the summit, Deng Xiaoping stated that the two sides should "close the past, and open the future." ${ }^{442}$ Seeing his Chinese counterpart effectively drop many of the historical issues that plagued bilateral relations allowed Gorbachev to propose official negotiations regarding the demilitarization of the Sino-Soviet border. While both sides had been reducing the troop levels along the border for a number of years, the PRC as a result of a reduction in the size of its armed forces due to modernization reforms, and the USSR as a result of Gorbachev's initiative, the border regions remained

\footnotetext{
${ }^{441}$ Mikhail Sergeevich Gorbachev, "Speech by Mikhail Gorbachev in Vladivostok, July 28, 1986," Novotsi Press Agency Pub. House, July 28, 1986, https://searchworks.stanford.edu/view/1921110

442 "Meeting between Mikhail Gorbachev and Deng Xiaoping (Excerpts)," The Wilson Center Digital Archive, May 16, 1989, http://digitalarchive.wilsoncenter.org/document/116536
} 
heavily militarized. ${ }^{443}$ Nevertheless, by the fall of 1989 , following Gorbachev's visit to Beijing, an expert group on the demilitarization of the border staffed by both parties convened its first meeting. ${ }^{444}$

Progress in the negotiation process regarding the demilitarization of the Sino-Soviet border had three immediate effects. The first, was that by reducing the number of forwarddeployed troops along the border and maintaining a purely defensive position, border delineation negotiations were able to proceed more effectively. The second, was that it allowed both parties, but specifically the USSR, to reduce their military expenditures. This was important since the USSR could not afford to maintain the forward-deployment of troops along the border at the levels maintained since the Sino-Soviet split. ${ }^{445}$ Additionally, it allowed the PRC to divert resources towards its development. ${ }^{446}$ In other words, while the two parties had economic interests for reducing troop levels, the primary economic rationale was different. The third, and last, effect was that this process served as the basis for confidence-building mechanisms between the PRC and the USSR.

After the collapse of the USSR, the PRC not only continued negotiations with the Russian Federation, but also directly engaged the newly-formed Central Asian Republics.

\footnotetext{
${ }^{443}$ Michael Parks, "Demilitarized Border Urged by Gorbachev," Los Angeles Times, May 17, 1989, http://articles.latimes.com/1989-05-17/news/mn-121_1_sino-soviet-gorbachev-soviet-officials/2

${ }^{444}$ Allen Carlson, Unifying China, Integrating with the World: Securing Chinese Sovereignty in the Reform Era (Stanford: Stanford University press, 2005), p. 64

${ }^{445}$ Herbert J. Ellison and Bruce A. Acker, "The New Russia in Asia: 1991-1995," The National Bureau of Asian Research 7(1), 1996, p. 36, http://www.nbr.org/publications/analysis/pdf/vol7no1.pdf

${ }^{446}$ See: Russell Ong, “China's Security Interests in Central Asia," Central Asian Survey 24(4), 2005, p. 428; Herbert J. Ellison and Bruce A. Acker, "The New Russia in Asia: 1991-1995," The National Bureau of Asian Research 7(1), 1996, p. 36, http://www.nbr.org/publications/analysis/pdf/vol7no1.pdf
} 
Premier Li Peng's 1994 tour of Uzbekistan, Kazakhstan, Turkmenistan, and Kyrgyzstan, set the tone for China's foreign policy towards the region. Premier Li emphasized increased trade and cultural links while actively assuaging concerns about China's intentions and role in the region ${ }^{447}$ This process culminated with the landmark signing of the "Treaty on Deepening Military Trust in Border Regions" in 1996 in Shanghai many years after the USSR was dissolved. Nevertheless, it included the PRC, the Russian Federation, Kazakhstan, Kyrgyzstan, and Tajikistan. This treaty stipulated that:

- "military forces deployed in border regions will not attack each other;

- no side will conduct military exercises that are targeted against the other;

- the scale, range and number of military exercises are to be limited;

- each side will inform the other of important military activities scheduled

- to be conducted within 100 kilometers of the border;

- each side will invite the other to observe military exercises that involve the use of live ammunition;

- dangerous military activities are to be avoided; and

- friendly communications between military forces and frontier guards in border regions should be promoted." 448

The following year, the parties gathered in Moscow and signed the "Treaty on Reduction of Military Forces in Border Regions.” Through this treaty the signatories agreed that:

- "military forces deployed in border regions were to be reduced to a level compatible with the goodneighbor relations and defensive in nature;

- no side would use, or threaten to use, force against the other or unilaterally seek military superiority;

- the military forces deployed in border regions would not attack the other side;

- all sides would reduce the number of military personnel including army, air force, air defense forces, and frontier guards, and also reduce the quantity of the main categories of weaponry deployed within 100 kilometers of the border;

- the upper limit after reduction, as well as the method and time limit for implementation, would be specified at a later date;

- the parties would exchange pertinent information on military forces in the border regions; and

${ }^{447}$ See Ian MacMillan, "Chinese Premier Begins Goodwill Tour of Central Asia," Los Angeles Times, 1994, http://articles.latimes.com/1994-04-20/news/mn-48237_1_central-asia; "Chinese Premier Leaves for Central Asia," United Press International, 1994, http://www.upi.com/Archives/1994/04/18/Chinesepremier-leaves-for-Central-Asia/5364766641600/

${ }^{448}$ Huasheng Zhao, "Central Asia in China's Diplomacy," in Central Asia: Views from Washington, Moscow, and Beijing, eds. Eugene Rumer, Dmitri Trenin, and Huasheng Zhao (Armonk: M.E. Sharpe, Inc. 2007), p. $139-140$ 
- implementation of the treaty was to be supervised." 449

Additionally, the treaty capped the number of army, air force, and air defense forces to 130,400 within 100 kilometers on each side of their respective borders along the entire 7,000 kilometer PRC border with its four post-Soviet neighbors. ${ }^{450}$ Consequently, by the second half of the 1990s, the PRC and its post-Soviet neighbors had not only reached important agreements on the delineation and demarcation of their shared borders, but also their demilitarization, thus marking the effective normalization of relations. Having made such monumental progress in these critical areas, the PRC then moved to establish consensus and cooperation from its neighbors on the "three evils." Doing this would require the PRC to socialize its neighbors in its securitization of these evils.

\section{Cooperation and Coordination on the "Three Evils"}

One of the key foreign policy goals of the PRC during the normalization process with post-Soviet states was to obtain their support and cooperation against minority separatist groups in Xinjiang. ${ }^{451}$ For the PRC, the stability of Xinjiang was a priority especially in the context of the independence of the Central Asian republics. This was due to the fact that these republics not only possessed sizeable Uygur diasporas, but were also the name-sake homelands of other Turkic groups which were also residing in Xinjiang. ${ }^{452}$

\footnotetext{
449 Ibid. p. 140

450 Ibid.

${ }^{451}$ Nicolas Becquelin, "Xinjiang in the Nineties," The China Journal 44, 2000, p. 70

452 See: Stanley Toops, "Spatial Results of the 2010 Census in Xinjiang," China Policy Institute, March 7 , 2016, https://cpianalysis.org/2016/03/07/spatial-results-of-the-2010-census-in-xinjiang/
} 
More importantly, as previously indicated, it was through these former SSRs that the USSR projected influence and challenged the territorial integrity of the PRC and the legitimacy of the CCP throughout the Cold War. The collapse of the USSR and the subsequent independence of the Central Asian Republics once again raised the specter of separatism in Xinjiang which had remained relatively dormant since the 1940s. In the context of the numerous rebellions, independence movements, riots, and other incidents since Xinjiang's incorporation into the Qing Empire in the $18^{\text {th }}$ century, the CCP has come to associate the province and its minority inhabitants with instability. As a result, these groups and their activities, no matter how minor or limited, have become securitized.

The securitization of Uyghurs and other Muslim minorities in Xinjiang is best encapsulated in the concept of the "three evil forces," or "three evils." As previously stated, the three evils refer to terrorism, separatism, and extremism. The referent object that is threatened by the three evils is the stability and territorial integrity of the PRC and, by successfully externalizing this narrative, the stability of its neighbors. ${ }^{453}$ The threat that the CCP perceives from its Muslim minority groups in Xinjiang has resulted in a number of policies that explicitly demonstrate successful domestic securitization. Furthermore, cooperation with its neighbors under the rubric of the three evils demonstrates Beijing's successful externalization of its domestic securitization process. And while the concept of the three evils was not fully institutionalized until the second phase in the SCO, as will be discussed in the following chapter, it was adopted by the Shanghai Five (China, Russia, Kazakhstan, Kyrgyzstan, and Tajikistan) during the normalization process in the 1990s.

\footnotetext{
${ }^{453}$ Stephen Aris, “The Shanghai Cooperation Organization: 'Tackling the Three Evils.' A Regional Response to Non-Traditional Security Challenges or an Anti-Western Bloc,” Europe-Asia Studies 61(3), 2009, p. 466
} 
Domestically, the CCP, perceiving Muslim minorities as a threat, has pushed for Han migration into Xinjiang in order to fundamentally alter the demographics of the province. ${ }^{454}$ Additionally, since 1991 , there has been a concerted effort to centralize authority in the province, resulting in greater oversight over cultural and religious practices. ${ }^{455}$ These policies can be explicitly observed in the extension of family-planning policies to minorities in the early $1990 \mathrm{~s},{ }^{456}$ which Uyghurs, and other Muslim minorities in Xinjiang, interpreted as an effort by the CCP to threaten their identity. ${ }^{457}$ Additionally, the gradual erosion of the Uygur language in schools, due to direct policies from the government, ${ }^{458}$ or indirectly as a result of economic development, ${ }^{459}$ raised tensions in the already restive region. Lastly, the gradual imposition of religious controls, such as on the

${ }^{454}$ See: Nicolas Becquelin, "Xinjiang in the Nineties," The China Journal 44, 2000, p. 74-76; Nicolas Becquelin, "Staged Development in Xinjiang," The China Quarterly 178, 2004, p. 358-378; Michael Clarke, "China's 'War on Terror" in Xinjiang: Human Security and the Causes of Violent Uighur Separatism," Griffith Asia Institute: Regional Outlook Paper 11, 2007, p. 7-8; Pablo Adriano Rodriguez, "Violent Resistance in Xinjiang (China): Tracking Militancy, Ethnic Riots and "Knife-Wielding' Terrorists," Historia Actual Online 30, 2013, p. 136

${ }^{455}$ See Nicolas Becquelin, "Xinjiang in the Nineties," The China Journal 44, 2000, p. 65-90; Arienne M. Dwyer, "The Xinjiang Conflict: Uyghur Identity, Language, and Political Discourse," East-West Center: Policy Studies 15, 2005, p. 1-124; Michael Clarke, "China's 'War on Terror" in Xinjiang: Human Security and the Causes of Violent Uighur Separatism," Griffith Asia Institute: Regional Outlook Paper 11, 2007, p. $1-28$

${ }^{456}$ Gardner Bovington, The Uyghurs: Strangers in the Own Land (New York: Columbia University Press, 2010), p. 58-59

${ }^{457}$ Pablo Adriano Rodriguez, "Violent Resistance in Xinjiang (China): Tracking Militancy, Ethnic Riots and "Knife-Wielding' Terrorists," Historia Actual Online 30, 2013, p. 136

${ }^{458}$ Arienne M. Dwyer, "The Xinjiang Conflict: Uyghur Identity, Language, and Political Discourse," EastWest Center: Policy Studies 15, 2005, p. 34-40

${ }^{459}$ Joanne Smith Finley, "Chinese Oppression in Xinjiang: Middle Eastern Conflicts and Global Islamic Solidarities among the Uyghurs," Journal of Contemporary China 16(53), 2007, p. 641 
observance of holidays, diets, clothing and other traditions, ${ }^{460}$ demonstrated that the CCP had equated Islam and Turkic ethnicity as sources of distinctiveness separating the minorities in Xinjiang and the Han majority. While superficially unproblematic, considering the PRC's official recognition of 55 minority groups and their respective rights, this distinctiveness is perceived as a threat to stability and, potentially, the territorial integrity of the PRC, thus it was seen as correlational to the three evils. ${ }^{461}$

In the context of Central Asian independence, this perception of Xinjiang's minorities motivated CCP officials to obtain the support and cooperation from its postSoviet neighbors in order to meet the domestic state-building objective of integrating Xinjiang into the rest of the country and maintaining stability and territorial integrity. However, they recognized that doing this would be more effective if all parties shared the same perspective on the threat posed by these minorities, thus, there was a need to externalize its securitization of the three evils and socialize its partners. While efforts were made throughout the border negotiating process in the late 1980s and early 1990s, the first breakthrough occurred on April 25, 1996, when Jiang Zemin, President of the PRC (19932003), and Boris Nikolayevich Yeltsin, President of the Russian Federation, met in Shanghai on the eve of the Shanghai Five's formation. The meeting between the two leaders resulted in Russia's recognition of the PRC as the sole legal government

\footnotetext{
${ }^{460}$ See: Arienne M. Dwyer, "The Xinjiang Conflict: Uyghur Identity, Language, and Political Discourse," East-West Center: Policy Studies 15, 2005, p. 29-34; "Devastating Blows: Religious Repression of Uighurs in Xinjiang," Human Rights Watch, April 11, 2005, https://www.hrw.org/report/2005/04/11/devastatingblows/religious-repression-uighurs-xinjiang

${ }^{461}$ See: Nicolas Becquelin, "Staged Development in Xinjiang," The China Quarterly 178, 2004, p. 375; "China: Assimilating or Radicalizing Uighurs?" European Parliament, 2014, http://www.europarl.europa.eu/EPRS/EPRS-AaG-538966-China-Assimilating-or-radicalising-UighursFINAL.pdf
} 
representing China and Taiwan, thus addressing one of China's key insecurities regarding the legal recognition of its sovereignty over its territory. ${ }^{462}$ The following day, the Shanghai Five mechanism was launched and the "Treaty on Deepening Military Trust in Border Regions" was signed. This event provided China a forum to socialize its negotiating partners into its securitization process. ${ }^{463}$ Furthermore, the signing of the "Treaty on Reduction of Military Forces in Border Regions" in Moscow the following year, paved the way for negotiation on other issues of mutual interest. Thus, in the third Shanghai Five summit at Almaty, Kazakhstan in 1998, the PRC made a concerted effort to put the three evils at the top of the agenda. ${ }^{464}$ This effort was successful since the three evils were explicitly mentioned in the joint statement released by the participants. ${ }^{465}$ The following year, at the fourth summit in Bishkek, Kyrgyzstan, the three evils were once again included in the joint statement, but more importantly, the members of the Shanghai Five agreed to coordinate efforts to combat these evils. ${ }^{466}$ These initial efforts would eventually lead to

\footnotetext{
462 “PRC: 'Text' of PRC-Russia Statement Released,” Beijing Xinhua Domestic Service, April 25 1996, FBIS-CHI-96-081, April 25, 1996

463 "History of Development of SCO," China Daily, June 12, 2006, http://www.chinadaily.com.cn/china/2006-06/12/content_6020347.htm
}

\footnotetext{
464 See: Jan A. Hessbruegge, "The Shanghai Cooperation Organization: A Holy Alliance For Central Asia?" al Nakhlah, 2004, p. 1-9, http://fletcher.tufts.edu/Al-

Nakhlah/Archives/ /media/Fletcher/Microsites/al\%20Nakhlah/archives/pdfs/hessbruegge\%202.pdf; Qingguo Jia, "The Success of the Shanghai Five: Interests, Norms and Pragmatism," Commonwealth Institute, http://www.comw.org/cmp/fulltext/0110jia.htm

465 “The Joint Statement of Participants of the Almaty Meeting - the Republic of Kazakhstan, People's Republic of China, the Kyrgyz Republic, the Russian Federation and the Republic of Tajikistan," CISLegislation, June 3, 1998, http://cis-legislation.com/document.fwx?rgn=3881

466 "Bishkek Declaration of Heads of State of the Republic of Kazakhstan, People's Republic of China, Kyrgyz Republic, Russian Federation and Republic of Tajikistan," CIS-Legislation, August 25, 1999, http://cis-legislation.com/document.fwx?rgn=3878
} 
the institutionalization of the three evils as a core ordering principle of cooperation between the Shanghai Five, and later, the SCO.

The PRC's efforts since 1996 to socialize its post-Soviet neighbors largely succeeded. Much of this was owed to the PRC's willingness to negotiate the border demarcation equitably and in accordance with international law, its pursuit of confidencebuilding efforts to demilitarize the border, and just as important, its continued adherence to the principle of non-interference. Furthermore, the PRC's ability to frame its securitization of the three evils in ways that would appeal to its post-Soviet neighbors meant that its efforts to socialize these states into this process would be more effective. In other words, by contending that the three evils posed a threat to the stability of their regimes, as well as presenting a demonstrable need to coordinate efforts to combat these evils due to their transnational characteristics, the PRC was presenting a vision that was consistent with the internal understandings of terrorism and extremism of the Russian Federation and the Central Asian Republics. ${ }^{467}$ Evidence of this success began to emerge after the Almaty summit. For its part, Kazakhstan forced many of the separatist organizations within its territory to disband and withdraw to Turkey. ${ }^{468}$ Additionally, Kyrgyzstan banned Uyghurs from forming any parties-in-exile. ${ }^{469}$ In fact, the PRC and Kyrgyzstan signed an extradition treaty in 1998, thus making it possible for Beijing to limit the possibility of cross-border

\footnotetext{
${ }^{467}$ Roy Allison, "Regionalism, Regional Structures and Security Management in Central Asia," International Affairs 80(3), 2004, p. 482

${ }^{468}$ Maria Brill Olcott, Central Asia's New States: Independence, Foreign Policy, and Regional Security (Washington DC: United States Institute of Peace Press), p. 36

${ }^{469}$ Ibid.
} 
separatist activities. ${ }^{470}$ There is evidence that both Kazakhstan and Kyrgyzstan have regularly handed over dissidents to the PRC. ${ }^{471}$ There is also an important political and economic dimension to this cooperation. For Nursultan Nazarbayev, Kazakhstan's president, cooperating with the PRC on this issue would not only bring greater political and economic benefits at home, but would also result in better treatment of the Kazakh diaspora living in Xinjiang. ${ }^{472}$ Islam Karimov, the former president of Uzbekistan, seeing greater benefits in cooperating with the PRC than in supporting the plight of the Uyghurs, actively discouraged other Turkic-speaking countries from supporting Uyghur groups within Xinjiang as well as in diasporas in their countries. ${ }^{473}$

\section{$\underline{\text { Conclusion }}$}

As indicated above, the first phase of the PRC's region-building project in Eurasia was dominated by a complex negotiating process leading to the normalization of relations. Just as importantly, the settlement of these negotiations paved the way for Beijing's greater engagement in the region. Thus, what appeared to be a seemingly unsurmountable border dispute marred by competing historical narratives, personal grievances, and ideological

\footnotetext{
470 "China, Kyrgyzstan Sign Joint Statement on Enhancing Co-op, friendship," Embassy of the People's Republic of China in the United States of America, August 15, 2007, http://www.chinaembassy.org/eng//xnyfgk/t351968.htm

${ }^{471}$ See: Nicolas Becquelin, "Xinjiang in the Nineties," The China Journal 44, 2000, p. 70-71; Rob Johnson, Oil, Islam, and Conflict: Central Asia Since 1945 (London: Reaktion Books, 2007), p. 193; Pablo Adriano Rodriguez, "Violent Resistance in Xinjiang (China): Tracking Militancy, Ethnic Riots and "KnifeWielding' Terrorists," Historia Actual Online 30, 2013, p. 140

${ }^{472}$ Rob Johnson, Oil, Islam, and Conflict: Central Asia Since 1945 (London: Reaktion Books, 2007), p. 193

${ }^{473}$ See: Nicolas Becquelin, "Xinjiang in the Nineties," The China Journal 44, 2000, p. 71; Pablo Adriano Rodriguez, "Violent Resistance in Xinjiang (China): Tracking Militancy, Ethnic Riots and "KnifeWielding' Terrorists," Historia Actual Online 30, 2013, p. 140
} 
differences, was largely settled by the end of the 1990s resulting in agreements that were nothing short of historic. Numerous factors played a role in the successful negotiation of the border, as well as the confidence-building process that resulted in the demilitarization of the border between the PRC and its post-Soviet neighbors. Nevertheless, it is clear that the negotiating position of the PRC, particularly its adherence to principles in international law as well as its willingness to pursue resolutions in an equitable and fair fashion generated significant goodwill throughout the process. This allowed the PRC to externalize its domestic securitization of the three evils and garner the support of its neighbors. This was important for Beijing since this was seen as a guarantee that external threats to its sovereignty over Xinjiang would not be supported by its immediate neighbors. In other words, this cooperation and coordination from the Russian Federation and the newlyindependent Central Asian republics would ensure that there would not be a repetition of history.

During this period, China's region-building project was focused on the post-Soviet states that bordered Xinjiang (see map 6). In fact, China's post-Soviet neighbors played an important role in Beijing's domestic state-building efforts. Furthermore, the normalization of relations between the PRC and its post-Soviet neighbors eroded the challenges initially posed by the collapse of the USSR. In essence, through the normalization of relations, the gateway to Eurasia was opened to Beijing, thus paving the way for an expansion of China's region-building project during the next phase. Although $\mathrm{CCP}$ officials recognized that Pakistan and Afghanistan represented legitimate challenges to Xinjiang's stability during this phase, it is evident that the disruptive forces that were unleashed by the Soviet collapse necessitated an immediate resolution if China was to successfully exercise control of the 
province. This explains why China approached the Pakistani and Afghani challenges through a bilateral approach as opposed to incorporating them into its region-building project during this phase, though this would change in the following decade. ${ }^{474}$

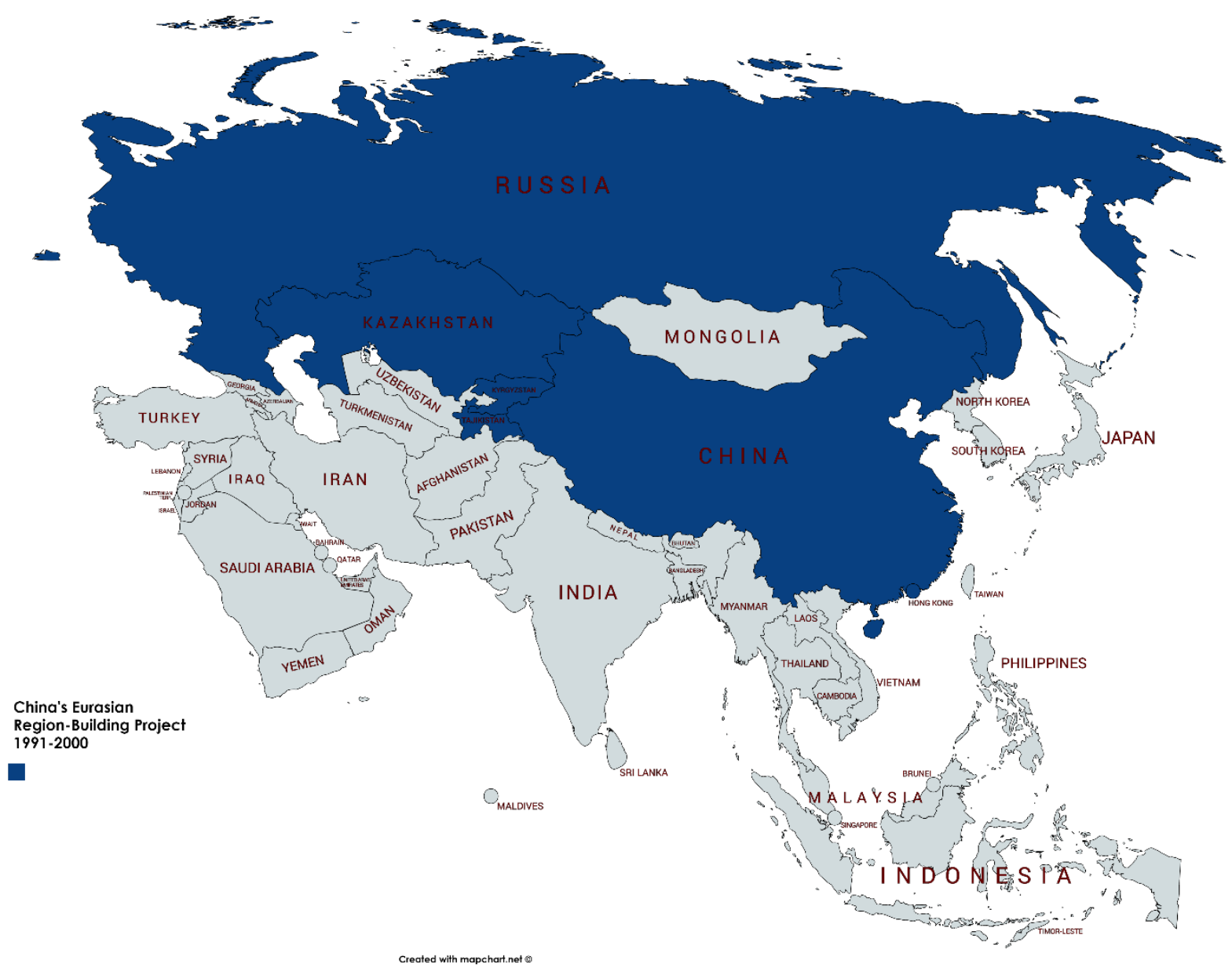

Map 6: China's Eurasian Region-Building Project 1991-2000. Generated in https://mapchart.net/

${ }^{474}$ See: Yitzhak Shichor, "The Great Wall of Steel: Military and Strategy in Xinjiang," in Xinjiang:

China's Muslim Borderland, ed. S. Fredrick Starr (Armonk: M.E. Sharpe, 2004), p. 144-145 \& 158; Sadia Fayaz, "China's Xinjiang Problem and Pakistan," The Dialogue VII(3), 2012, p. 247 


\section{Chapter 3: 2000-2013: National Consolidation and Regional Institutionalization}

By 2000, relations between the PRC and its post-Soviet neighbors had been normalized for a number of years. They had delineated and demarcated almost all their shared borders, leaving only minor sections to be negotiated during the first decade of the $21^{\text {st }}$ century. Furthermore, with the demilitarization of the border and the cooperation on the three evils, the prospect of armed conflict between the PRC and its post-Soviet neighbors had been reduced. Just as important, however, was that the success of these developments convinced the $\mathrm{CCP}$ that the sovereignty and territorial integrity of the PRC, especially in borderland provinces like Xinjiang, would be respected. This led to increasing political and economic interactions between them and facilitated the PRC's efforts to more effectively develop and integrate its western provinces by opening its frontier to Eurasian markets and resources. It is, therefore, unsurprising that access to Central Asian markets and resources played such an important role in Xinjiang's double-opening strategy during the 1990s especially since this strategy was designed to facilitate the CCP's state-building efforts by galvanizing economic development and bridging the gap with the coastal provinces. Successfully doing this would lead to greater state capacity and thus, more effective control of minority regions.

As indicated in chapter 2, the double-opening strategy was largely successful in beginning the process of more effectively integrating Xinjiang into the rest of the country. Additionally, it brought increased levels of development by increasing central investment and opening land ports with Central Asia. Nevertheless, the gap between the coastal provinces and the western ones like Xinjiang continued to widen. The widening gap was to be expected; after all, it was a product of priorities laid out by Deng Xiaoping's open 
door policy. Deng and other reformers believed that transforming China's command economy and opening it to market forces required a gradual approach. The selection of the southeastern provinces as the testbeds for reforms was an explicit indication that this region would receive preferential treatment. This preferential position was cemented by General Secretary Zhao Ziyang (1987-1989) at the $13^{\text {th }}$ National Congress of the Communist Party of China on October 25, 1987. At this meeting, Zhao promoted the development of the coastal region and its integration into the global economy by transitioning into export-led economies. ${ }^{475}$ In other words, the "coastal development strategy," as it would later be called, was the centerpiece of China's open door policy.

The privileged position that the coastal provinces enjoyed was undergirded by a spillover logic. As Zhao indicated at the National Congress, the development of the special economic zones would spillover into other coastal cities, the coastal region at large, and ultimately, the interior regions. ${ }^{476}$ Supporters of the coastal development strategy like Ren Zhongyi, Party Secretary of Guangdong (1980-1985), the first province to begin economic reforms, shared this sentiment contending that initial gaps between the coast and the interior provinces would be temporary since the development of the former would lead to the development of the latter. ${ }^{477}$ Zhao preferred the prioritization of coastal development since he believed that the differences in the economic and cultural condition of the coastal

\footnotetext{
475 Ziyang Zhao, "Advance Along the Road of Socialism with Chinese Characteristics," Beijing Review 30(45), November 9-15, 1987, p. I-XXVII

${ }^{476}$ Ibid. p. X

${ }^{477}$ Baocheng Han, "Importance Attached to Coastal Development," Beijing Review 31(17), April 25-May 1, 1988, p. 16
} 
and inland areas made it impossible to enact an economic development strategy evenly across the country. In essence, the coast was better positioned to take advantage of market reforms, thus, it was necessary to expedite the reform and development of the coastal regions first. ${ }^{478}$

This spillover logic was also supported by Deng Xiaoping who in a speech on September 12, 1988 outlined his "two general situations" approach by stating that the coastal areas

\begin{abstract}
"should accelerate their opening to the outside world, and we should help them develop rapidly first; afterwards they can promote the development of the interior. The development of the coastal areas is of overriding importance, and the interior provinces should subordinate themselves to it. When the coastal areas have developed to a certain extent, they will be required to give still more help to the interior. Then, the development of the interior provinces will be of overriding importance, and the coastal areas will in turn have to subordinate themselves to it." $" 479$
\end{abstract}

In other words, the privileged status of the coastal provinces would be promoted, and the western provinces' development would have to wait until the time was ready for their coastal counterparts to facilitate their development. Thus, even though the eighth five-year plan signaled an attempt to rectify the growing fragmentation of the national economy and the widening gap between the coast and the rest of the country in the early 1990s, the conditions were not well-suited for a serious reorientation of the priorities set out by central authorities in the late 1980s. This is not to say that the privileged position of the coast was not challenged during these early stages. Numerous officials representing interior provinces voiced concerns regarding the potential economic and social problems that this

\footnotetext{
${ }^{478}$ Ziyang Zhao, “Zhao on Coastal Areas’ Development Strategy,” Beijing Review 31(6), February 8-14, 1988, p. 19

${ }^{479}$ Deng Xiaoping, “The Central Leadership Must Have Authority," in Selected Works of Deng Xiaoping Volume 3, ed. Deng Xiaoping (Beijing: Beijing Foreign Language Press, 1994), p. 181
} 
approach could have on their respective provinces during this period. ${ }^{480}$ However, with the support of Deng Xiaoping, the coastal development strategy took precedence above all else. Thus, although key Party officials like General Secretary Jiang Zemin (1989-2002) and Premier Li Peng (1988-1998) emerged in the early 1990s expressing support for a more balanced approach to national economic development, they were unable to shift policy priorities due to Deng's support of continued coastal development. ${ }^{481}$

In fact, Deng Xiaoping's "southern tour" in 1992 ensured that the coastal development strategy would remain on course. This tour not only highlighted the pivotal position that Deng occupied in the CCP despite not holding any relevant official position within the Party at this time, but is also credited with saving the economic reforms in the PRC by settling the post-Tiananmen debates on the risks posed by further reforms and the ideological challenge posed by capitalism. ${ }^{482}$ Deng Xiaoping ended this debate by contending that a planned economy was not equivalent to socialism, since capitalism also involved planning, adding that a market economy was not equivalent to capitalism, because there were markets under socialism too. For Deng, the "essence of socialism" was the "liberation and development of the productive forces," the "elimination of exploitation and polarization," and ultimately, the "achievement of prosperity for all." Therefore, the chief

\footnotetext{
${ }^{480}$ Baocheng Han, "Importance Attached to Coastal Development," Beijing Review 31(17), April 25-May 1, 1988, p. 17

${ }^{481}$ Dali L. Yang, Beyond Beijing: Liberalization and the Regions in China (London: Routledge, 1997), p. 90-92

${ }^{482}$ See: Lei Wang, "26 Years on: Deng Xiaoping Reaffirms China's Commitment to Reform," China Global Television Network, January 18, 2018, https://news.cgtn.com/news/78497a4d79677a6333566d54/share_p.html; Victor Zhikai Gao, "Opinion: Why is Deng Xiaoping's 1992 Southern Inspection Tour Still Relevant Today? China Global Television Network, January 19, 2018, https://news.cgtn.com/news/3451444e79677a63335666d54/share_p.html
} 
criterion for the reforms should be whether a reform "promotes the growth of the productive forces in a socialist society," and whether it increases the "overall strength of the socialist state and raises living standards." ${ }^{483}$ Nevertheless, although it is clear that Deng saved the reform movement in the early 1990s, he still signaled a preference for coastal development as opposed to the balanced approach preferred by other reformers like Jiang Zemin and Li Peng as he continued to advocate for a staged approach to development that privileged the coastal areas. Based on Deng's "two general situations" approach, focus on the interior provinces would only occur once the coast had "developed to certain extent," and just as important, people in these provinces would be living a "comfortable life." This, he estimated, would occur by the end of the century. ${ }^{484}$ Therefore, beyond providing legitimacy for continued economic reforms and coastal development prioritization, Deng also provided a timeline that served as the safeguard against premature reorientation of national development priorities. Collectively, this meant that any initiative geared towards the development of the interior provinces would remain a secondary priority despite the growing discontent from interior provinces, and the social tensions emanating from the uneven development of the country.

Deng's retirement from public life after 1993, however, opened the door for a rebalancing of development priorities. Thus, while Jiang Zemin and Li Peng were initially preoccupied with legitimizing their emergence as the third generation of $\mathrm{CCP}$ leaders and

\footnotetext{
${ }^{483}$ Deng Xiaoping, "Excerpts from Talks Given in Wuchang, Shenzhen, Zhuhai, and Shanghai," in Selected Works of Deng Xiaoping Volume 3, ed. Deng Xiaoping (Beijing: Beijing Foreign Language Press, 1994), p. 242

${ }^{484}$ Ibid. p. 243
} 
were consequently focused on sustaining economic growth and political stability, they were increasingly sensitive to the growing disparities between the coastal and interior regions. ${ }^{485}$ Furthermore, the voices of discontent from Party officials in the interior provinces, particularly from ethnic-minority-dominated ones like Xinjiang, continued to grow. In a 1993 meeting in Urumqi, Xinjiang, officials raised their concerns about the growing social risks that could emerge as a result of being left behind by the rapid development of the coastal provinces. ${ }^{486}$ The following year, a study conducted by research fellow Hu Angang of the National Condition Analysis and Research Group of the Chinese Academy of Science, "It has Become an Urgent Matter to Solve the Widening Gap Between Minority Nationality Regions and Coastal Developed Regions," drove this point further. This study, conducted during a seminar for nationalities and religious affairs cadres from local committees of the Chinese People's Political Consultative Conference (CPPCC), representing over thirty provinces and autonomous regions, posed a number of questions that provided insight into the cadres' perception of the widening economic gap and its consequences. ${ }^{487}$

Although the survey posed fourteen questions, a handful are very instructive as to the cadres' general sentiments on the issue of the widening gap. The first question asked whether the economic gap between minority nationality regions and the coastal developed

\footnotetext{
${ }^{485}$ Dali L. Yang, Beyond Beijing: Liberalization and the Regions in China (London: Routledge, 1997), p. 91-92

${ }^{486}$ Marcus W. Brauchli, “China's Hinterland Seeks Coast's Progress: Ethnic and Environmental Issues Slow the Advance," The Wall Street Journal, November 3, 1993, https://search-proquestcom.ezproxy.fiu.edu/docview/398380735? accountid=10901

487 “Gap Seen Between Coastal, Nationality Regions," Lien Ho Pao, Hong Kong, November 7, 1994, FBISCHI-94-229, November 24, 1994
} 
regions had widened, narrowed, or not changed much. On this question, $94.2 \%$ of the cadres agreed that it had widened. Question two asked whether the gap was too large, too small, or normal. To this, $83.7 \%$ of respondents answered that it was too large. When asked whether the existing gap would continue to widen, narrow, or not change much, $65.7 \%$ answered that it would continue to widen. Additionally, when asked whether the issue of the widening gap was an urgent matter or if it was too soon to worry, the respondents were unanimous in their answer that the issue was urgent. This signified an important break in perception between the local and some central authorities who believed that the development gap could wait to be addressed in the $21^{\text {st }}$ century. When asked what the worst outcome of the widening gap would be, $80 \%$ answered that it would be social instability. Lastly, when asked whether the nationalities question (unrest) was primarily a development question or a class question, again, all cadres answered that it was a development question, thus highlighting the link between stability, security, and development. In other words, the local cadres had internalized the security-development nexus logic. ${ }^{488}$

It appears that local leaders' ability to link the widening economic gap between the coastal and interior provinces with social unrest resonated well with central authorities. This was due to the fact that this narrative appealed to preexisting concerns within the upper echelons of the CCP. As a result, during a high-level meeting at Beidaihe in 1995, when several central and western provincial leaders appealed to the central authorities in Beijing to take concrete action to redress the imbalance between the impoverished western provinces and the wealthier eastern coast, or face loss of control and order, they found

\footnotetext{
488 Ibid.
} 
success. ${ }^{489}$ After this meeting, central authorities agreed to take concrete steps to address this issue at the $5^{\text {th }}$ plenary session of the $14^{\text {th }}$ Central Committee of the Communist Party of China, where the guidelines for the ninth five-year plan were adopted.

Like the eighth five-year plan, the ninth five-year plan (1996-2000) sought to address the fragmentation of the national economy by assisting central and western provinces in their development. By now, the social consequences arising as a result of interior provinces falling further behind required immediate attention. In March 1996 during a session of the National People's Congress (NPC), Jiang Zemin submitted the proposal for the ninth five-year plan, "insisting on coordinated regional economic development and gradually reducing the gap in development between regions. ${ }^{490}$ In a report outlining the ninth five-year plan, Li Peng stated that central authorities would "pay more attention to the development of the central and western parts of the country, introduce policies conducive to slowing down the widening of regional disparities and strive to narrow them. ${ }^{491}$ In addition to making the narrowing of the development gap between provinces a core component of the ninth five-year plan, Premier Li provided the roadmap for addressing this problem. Unsurprisingly, the policy guidelines mirrored those of the

\footnotetext{
${ }^{489}$ Willy Wo-Lap Lam, "Provincial Leaders Link Aid, Law, Order," Hong Kong, September 9, 1995, FBISCHI-95-175, September 11, 1995

${ }^{490}$ Hongyi Harry Lai, "China's Western Development Program: Its Rationale, Implementation, and Prospects," Modern China 28(4), 2002, p. 435

${ }^{491}$ Peng Li, "Report on the outline of the Ninth Five-Year Plan (1996-2000) for National Economic and Social Development and the Long-range Objectives to the Year 2010 (Excerpts)," China.org, 1996, http://www.china.org.cn/95e/95-english1/2.htm
} 
eighth five-year plan and double-opening strategy adopted for Xinjiang in the first half of the 1990s.

According to the report, infrastructure and resource surveying and development would be ramped up, along with the expansion of the industrial base, particularly in resource processing. ${ }^{492}$ In other words, the interior provinces would not remain purely raw material providers for the developed coastal regions; they could now process their resources internally and move up the value-added chain. This was geared to address one of the key criticisms that resource-rich provinces like Xinjiang aimed at the coastal provinces, specifically, that the coastal provinces were exploiting the internal pricing system by purchasing raw materials from the resource-rich provinces in the west, and thus, leaving them in a dependency relationship. ${ }^{493}$ In fact, this was something that Zhao warned against when he developed the coastal development strategy. ${ }^{494}$ The new plan also sought to increase economic linkages between China's coastal, central and western regions in order to more effectively manage the national economy and provide the pathway for coastal provinces to invest in the interior provinces. Lastly, this plan aimed to improve the

\footnotetext{
492 Ibid.

493 See: Gaye Christoffersen, "Xinjiang and the Great Islamic Circle: The Impact of Transnational Forces on Chinese Regional Economic Planning," The China Quarterly 133, 1993, p. 140; Dali L. Yang, Beyond Beijing: Liberalization and the Regions in China (London: Routledge, 1997), p. 63-66; Hongyi Harry Lai, "China's Western Development Program: Its Rationale, Implementation, and Prospects," Modern China 28(4), 2002, p. 438; Qunjian Tian, "China Develops its West: Motivation, Strategy and Prospect," Journal of Contemporary China 13(41), 2004, p. 620

${ }^{494}$ Ziyang Zhao, “Zhao on Coastal Areas' Development Strategy,” Beijing Review 31(6), February 8-14, 1988, p. 19
} 
investment environment in the interior provinces in order to attract greater levels of foreign direct investment (FDI). ${ }^{495}$

On the surface, the ninth five-year plan, coupled with the fiscal reforms of 1994 that increased the central government's ability to transfer payments to interior provinces, ${ }^{496}$ presented an opportunity for the central authorities to address key social and economic challenges emanating from the widening development gap, particularly the north-south divide in restive provinces like Xinjiang. In fact, the growing ethnic unrest in Xinjiang throughout the 1990s was perceived to be a serious threat to social stability and the CCP's control of the province, ${ }^{497}$ hence the focus on national integration, state capacity, and international trade linkages in the double-opening strategy and the eighth and ninth fiveyear plans. However, despite a shift in central authority priorities in the mid-1990s, the ninth five-year plan, much like its predecessor, had limited results. Much of the problem rested precisely on the nature of the fiscal reforms themselves. Although the 1994 fiscal reforms gave the central government greater access to revenue and thus, added funds to redistribute to underdeveloped provinces, it only increased the dependency of the interior provinces. For example, taxes were raised on resource-extracting industries and were

\footnotetext{
${ }^{495}$ Peng Li, "Report on the outline of the Ninth Five-Year Plan (1996-2000) for National Economic and Social Development and the Long-range Objectives to the Year 2010 (Excerpts)," China.org, 1996, http://www.china.org.cn/95e/95-english1/2.htm

${ }^{496}$ Victor Shih, "Development, the Second Time Around: The Political Logic of Developing Western China," Journal of East Asian Studies 4(3), 2004, p. 429

${ }^{497}$ Nicolas Becquelin, "Xinjiang in the Nineties," The China Journal 44, 2000, p. 72
} 
lowered on manufacturing and retail sectors. ${ }^{498}$ This posed a problem for interior provinces, especially resource-rich ones like Xinjiang since most of their revenue originated from resource extraction. In other words, the tax structure in the fiscal reforms benefitted the coastal regions to the detriment of the interior ones. Furthermore, efforts to promote exports in the coastal provinces led central authorities to grant a series of tax rebates, which, as exports grew, increased the cost of the rebates and limited the center's ability to transfer payments to the interior provinces during this period. ${ }^{499}$ In other words, a key reform from 1994 hampered efforts to rebalance the national economy during the second half of the 1990s.

In the midst of these challenges, provincial leaders from the interior provinces continued to make appeals to central authorities during sessions of the NPC and the CPPCC in 1997 for additional aid and concrete actions aimed at reducing regional inequality. By 1998, at the $3^{\text {rd }}$ plenary session of the $15^{\text {th }}$ Central Committee of the Communist Party of China, members of the Northwest Group and the Southwest Group accused coastal provinces, particularly Guangdong, Fujian, and Hainan, of stealing their talent by offering higher wages and demanded their punishment. ${ }^{500}$ This was an important issue area since the provinces in the west possessed very little human capital in comparison to their coastal counterparts. To lose their already meager human capital would only make their

\footnotetext{
${ }^{498}$ See: Nicolas Becquelin, "Xinjiang in the Nineties," The China Journal 44, 2000, p. 65-90; Hongyi Harry Lai, "China's Western Development Program: Its Rationale, Implementation, and Prospects," Modern China 28(4), 2002, p. 439

${ }^{499}$ Hongyi Harry Lai, “China's Western Development Program: Its Rationale, Implementation, and Prospects," Modern China 28(4), 2002, p. 439

${ }^{500}$ Ibid. p. 435
} 
development more difficult. There were also concerns that the center was failing to honor its pledge to reimburse provinces that were losing revenue as a result of the fiscal reforms, something that exacerbated the condition of dependency of these provinces to the center. ${ }^{501}$

These realities, coupled with the need to continue state-building efforts and increase state capacity in minority areas, ultimately motivated Jiang Zemin to propose a national strategy for the development of the interior provinces. This strategy, much like Zhao's coastal development strategy, sought to bring about the development of the interior provinces through economic reforms, central government investment, and linkage of these provinces to Eurasian markets. It was hoped that this would address the widening economic gap and the social problems that accompanied it. Furthermore, by promoting the development of these western provinces, the CCP would also be further integrating and increasing state capacity in restive provinces like Xinjiang, thus increasing its ability to respond to social unrest. The new state-building initiative, called the Great Western Development (GWD), would serve as a platform for China's political and economic projection into Eurasia and the promotion of an expanded region-building project.

\section{The Great Western Development Strategy}

What formally became the Great Western Development strategy began to take shape in two consecutive speeches by Jiang Zemin in the summer of 1999. These two speeches focused on key areas of concern for the CCP as it sought to address some of the economic and social repercussions of the coastal development strategy. On June $9^{\text {th }}$, at the CCP Central Committee Meeting on Aiding the Poor, Jiang claimed that the conditions for

\footnotetext{
${ }^{501}$ Nicolas Becquelin, "Xinjiang in the Nineties," The China Journal 44, 2000, p. 72-73
} 
speeding up the development of central and western China were present and that the time was ripe to focus on this front. ${ }^{502}$ Jiang added that while accelerating the economic development of the coastal region should continue to be pursued, the Party should not lose the opportunity to speed up the development of the central and western regions. ${ }^{503}$ Lastly, in an effort to pursue a more balanced national development strategy, Jiang concluded that the development of the central and western regions "should become a major strategic task for the party and the state, and should be placed in a more noticeable position." 504 Following this speech, on June 17, Jiang Zemin chaired the Conference on the Reform and Development of State-Owned Enterprises in the Five Northwestern Provinces, where he first used the phrase "great western development." 505 At this meeting, Jiang stated that "implementing the great development of the western area has an important economic, political, and social meaning for national reform and construction and the long-term stability of the state," $" 506$ thus using rhetoric explicitly linking development with security and stability. In other words, the security-development nexus served as the underlying logic for the GWD strategy much in the same way as it did for the double-opening strategy and preceding five-year plans.

\footnotetext{
502 Hongyi Harry Lai, “China’s Western Development Program: Its Rationale, Implementation, and Prospects," Modern China 28(4), 2002, p. 436

503 Ibid.

504 Ibid.

505 See: Hongyi Harry Lai, “China’s Western Development Program: Its Rationale, Implementation, and Prospects," Modern China 28(4), 2002, p. 436; Victor Shih, "Development, the Second Time Around: The Political Logic of Developing Western China," Journal of East Asian Studies 4(3), 2004, p. 429

506 Victor Shih, "Development, the Second Time Around: The Political Logic of Developing Western China," Journal of East Asian Studies 4(3), 2004, p. 429
} 
Jiang's June $9^{\text {th }}$ speech was accurate in indicating that the time was ripe. In 1981 , at the $12^{\text {th }}$ National People's Congress of the Communist Part of China, Deng Xiaoping had set a goal of quadrupling the gross annual value of industrial and agricultural output in 20 years. ${ }^{507}$ This was later amended in 1984 to quadrupling the gross national product (GNP) as well as reaching a gross national product per capita of $\$ 800$ by the end of the century in order to improve the living standards of the Chinese people. ${ }^{508}$ These goals were met early as by 1998 the GNP had quintupled and the GNP per capita had reached $\$ 860 .{ }^{509}$ In other words, the economic conditions laid out by Deng in the 1980s and the estimated timeline in his "two general situations" had been met. This provided the economic and political opening for Jiang to move forward with the GWD strategy. In fact, Jiang Zemin and his new Premier, Zhu Rongji (1998-2003) presented the plan for the GWD strategy as a natural progression of Deng Xiaoping's "two general situations" approach, thus giving the new initiative added legitimacy. ${ }^{510}$

The Great Western Development strategy encapsulated much of the efforts that were made in the eighth and ninth five-year plans, particularly their goal of addressing regional development imbalances, the continued fragmentation of the national economy, and the potential for social unrest as a result of this growing problem. However, what

\footnotetext{
${ }^{507}$ Deng Xiaoping, "We Shall Concentrate on Economic Development," in Selected Works of Deng Xiaoping Volume 3, ed. Deng Xiaoping (Beijing: Beijing Foreign Language Press, 1994), p. 15

${ }^{508}$ Deng Xiaoping, "We Should take a Long-Range View in Developing Sino-Japanese Relations," in Selected Works of Deng Xiaoping Volume 3, ed. Deng Xiaoping (Beijing: Beijing Foreign Language Press, 1994), p. 42

509 “China,” The World Bank, 2018, https://data.worldbank.org/country/china

510 Victor Shih, "Development, the Second Time Around: The Political Logic of Developing Western China," Journal of East Asian Studies 4(3), 2004, p. 428
} 
separated the GWD strategy from these plans was the fact that this was a comprehensive national strategy in the same manner as Zhou's coastal development strategy. ${ }^{511}$ This indicated that the upper echelons of the CCP leadership were now behind a national effort dedicated to the development of the western provinces, many of which were some of the most underdeveloped in the PRC. As a result, these provinces would be receiving greater amounts of resources.

On January 16, 2000, a Leading Group to Develop the Western Region under the purview of the State Council was formed. This group was headed by Premier Zhu Rongji and Vice-Premier Wen Jiabao (1998-2003). ${ }^{512}$ The creation of the group began the flow of numerous reports outlining the guidelines of the GWD strategy. One of the first that shed light on the focus areas of the strategy was released on November 2, 2000. This document provided an introduction to the implementation of the GWD strategy and outlined four target areas for development. The first target area focused on infrastructure, particularly in the transportation, water, energy, and telecommunications sectors. The second target area focused on ecological protection and sought to rehabilitate forests and grasslands in order to mitigate worsening environmental conditions, especially the problem of water scarcity and desertification that afflicted many western provinces like Xinjiang. ${ }^{513}$ The third target area aimed to restructure the industries in the western provinces by focusing on the

\footnotetext{
${ }^{511}$ Qunjian Tian, “China Develops its West: Motivation, Strategy and Prospect," Journal of Contemporary China 13(41), 2004, p. 621

${ }^{512}$ Hongyi Harry Lai, “China's Western Development Program: Its Rationale, Implementation, and Prospects," Modern China 28(4), 2002, p. 450

513 Qi Feng, Hua Ma, Xuemei Jiang, Xin Wang, and Shixiong Cao, "What has Caused Desertification in China? Scientific Reports 5(15998), 2015, p. 1-8
} 
advantages that each individual province possessed as well as promote greater levels of processing capability within these provinces. This was promoted in order to allow them to move up the value-added chain. In addition to these goals, the third target area also sought to develop the tourism sector of the western provinces in order to provide these provinces with a new economic sector. The fourth and last target area in the report focused on the development of science and technology in the western provinces as well as pushing for nine compulsory years of education in order to improve the human capital base of the area. $^{514}$

The GWD strategy was officially incorporated into the tenth five-year plan (20012005), where it occupied an important position in the national agenda. In his report on the tenth five-year plan at the $4^{\text {th }}$ plenary session of the $9^{\text {th }}$ National People's Congress on March 5, 2001, Premier Zhu reiterated the core components of the 2000 report, however, a number of changes and additions were made. The main change that was made was that the first two target areas, infrastructure development and ecological protection, were elevated to top priorities of the GWD strategy. ${ }^{515}$ As previously discussed, infrastructure development was not only consistent with state-building efforts, but also provided the foundations of economic development as well as increased state capacity in formerly isolated regions in western China. This ultimately augmented the central authority's ability

\footnotetext{
514 "Introduction to the Implementation of the Great Western Development Strategy in China," Ministry of Environmental Protection of the People's Republic of China, November 2, 2000, http://english.sepa.gov.cn/Events/Special_Topics/AGM_1/2000agm/leaderspeech2000/201605/t20160524_ 345016.shtml

${ }^{515}$ Rongji Zhu, "Report on the Outline of the Tenth Five-Year Plan for National Economic and Social Development (2001)," The Central People's Government of the People's Republic of China, 2001, http://english1.english.gov.cn/official/2005-07/29/content_18334.htm
} 
to exercise control. Ecological protection was elevated since many of the provinces in the west, especially Xinjiang, were suffering from severe ecological degradation which threatened to undermine efforts to deliver economic development. Of particular concern were the issues of water scarcity and desertification in the region. In other words, both of these components were intrinsically linked to the security-development nexus logic that underpinned the thinking of Party officials.

An important addition that was made was the official announcement of major projects. Some of these included the transmission of natural gas and electricity from the west to the east, the Qinghai-Tibet railway, and the development of an ecological green belt in the western provinces. ${ }^{516}$ Another important addition that was made was the highlighting of transportation routes such as the Eurasian Continental Landbridge. These routes would connect major cities that would act as economic centers which would play leading roles in the development of adjacent areas. In other words, these routes would function as economic corridors much like the corridors subsequently proposed in the Belt Road Initiative.

Zhu Rongji's report also indicated that the state would increase the amount of transfer payments to western provinces, although he cautioned that these provinces should rely primarily on their own efforts and hard work. This illustrated the recognition that the development of the west could not be wholly underwritten by the center. To address this potential shortcoming $\mathrm{Zhu}$ argued that improving the investment environment in the western provinces should be part of the GWD strategy. Furthermore, he called on the

\footnotetext{
516 Ibid.
} 
coastal provinces to "strengthen [their] economic and technological cooperation with the central and western regions by various means to support and stimulate their economic development and to increase its own flexibility for structural adjustment and economic growth at the same time." 517 These two proposals not only helped alleviate the economic burden on the center, but also helped address the growing problem of national economic fragmentation since it sought greater economic integration between coastal, central, and western provinces. Looking closely, it is evident that the GWD strategy was shaping up to be a national version of Xinjiang's double-opening strategy. In essence, it sought the effective integration of minority underdeveloped regions into the rest of the country, while simultaneously opening these spaces to foreign investment. In other words, the GWD strategy was a state-building project that also necessitated a region-building project in order to increase its chances of success.

After the GWD's incorporation into the tenth five-year plan, on August 28, 2001, the State Council's General Office released a report titled "Suggestions on the Implementation of Policies and Measures Pertaining to the Development of the Western Region." This report built on Premier Zhu's statements at the NPC by elaborating on the specific projects that would be pursued as well as the sources for funding them. Of particular importance were the types of loans and inceptives provided to different western provinces and how each of the state ministries would support different aspects of the GWD strategy. Additionally, in its elaboration of the policies that would be implemented under the Great Western Development strategy, the report indicated how these initiatives would

\footnotetext{
517 Ibid.
} 
benefit ethnic minorities directly. The State Council report stayed true to the spirit outlined in the two previous reports, specifically the need to invest in infrastructure, rehabilitate the environment, and improving the investment conditions by providing incentives as well as developing technological and human resources. ${ }^{518}$ In February 2002, this report was capped by the release of the "Overall Plan of Western Region Development During the Tenth Five-Year Plan Period.”

The plan built on its predecessors by explicitly stating the overarching strategic goal of the GWD strategy. According to the plan, "the regional disparities between the Western Region and other regions should be diminished considerably, the relative underdevelopment of the Western Region should be reversed, transforming it into a prosperous and advanced new West where life is stable, ethnic groups are united and the landscape is beautiful." ${ }^{519}$ It was estimated that this transformation would occur by the middle of the $21^{\text {st }}$ century when the PRC had achieved modernization at the national level. The plan also explicitly revealed that the GWD strategy was more than an economic initiative, it also possessed political significance. In essence the GWD strategy was also meant to "consolidate the unity of ethnic groups, ensure border safety and social stability and promote social progress." ${ }^{, 520}$

\footnotetext{
518 "Circular of the State Council's General Office on the Distribution of "Suggestions on the Implementation of Policies and Measures Pertaining to the Development of the Western Region" Submitted by the Western Region Development Office of the State Council," The State Council of the People's Republic of China, September 29, 2001, https://www.tid.gov.hk/english/trade_relations/files/lawe.pdf

519 "Overall Plan of Western Region Development During the Tenth Five-Year Plan Period," China.org, 2002, http://www.china.com.cn/market/hwc/400823.htm

${ }^{520}$ Ibid.
} 
This led scholars like Nicolas Becquelin to argue that the national goals of integration and state-building superseded economic ones. ${ }^{521}$ He also argued that the GWD strategy made explicit the central authority's long-standing policies of integrating and assimilating minorities and the places they resided, into the rest of the country. ${ }^{522}$ In fact, Jiang Zemin indicated that the GWD strategy was crucial to China's stability, the CCP's hold on power, and the revitalization of the Chinese people. ${ }^{523}$ However, it was clear that the economic dimension couldn't really be disaggregated from the political one since the logic of the security-development nexus regarded the political (security) and the economic (development) dimensions as co-constitutive. From this perspective, it was evident that the economic development of the western provinces, particularly those with significant minority populations like Xinjiang, represented not just an opportunity to provide an improved standard of living and consequently mitigate potential unrest as a result of poor economic conditions, but also provided the infrastructure through which the state could exercise greater control of these areas. Consequently, it is not surprising that the mechanisms through which economic development was being promoted also increased the level of control of the center in these minority provinces, as well as their level of dependency. 524

\footnotetext{
${ }^{521}$ Nicolas Becquelin, "Staged Development in Xinjiang," The China Quarterly 178, 2004, p. 362

${ }^{522}$ Ibid p. 358-378

${ }^{523}$ John Pomfret, "China: Go West, Young Han; Beijing Urging Dominant Ethnic Group to Resettle, Develop Restive Regions," The Washington Post, September 15, 2000, https://search-proquestcom.ezproxy.fiu.edu/news/docview/409046210/fulltext/560088F9060E4F8APQ/1?accountid=10901

${ }^{524}$ See: Matthew D. Moneyhon, “China’s Great Western Development Project in Xinjiang, Economic Palliative, or Political Trojan Horse?" Denver Journal of International Law \& Policy 31(3), 2003, p. 491519; Nicolas Becquelin, “Staged Development in Xinjiang," The China Quarterly 178, 2004, p. 358-378;
} 
Based on historical trends of western development initiatives as well as CCP narrative, the GWD strategy represented a consolidation of ideas and initiatives proposed throughout the 1980s, and especially the 1990s. This means that the GWD strategy did not necessarily present a new perspective or make revolutionary changes to the center's approach to national development, rather, it was an evolutionary step in the CCP's longrunning state-building effort that built on previous initiatives. Thus, it can be argued that given the modest progress made throughout the 1990s, particularly in provinces like Xinjiang during the double-opening phase, the GWD strategy provided the means for central authorities to consolidate their gains on the ground. In other words, local initiatives like Xinjiang's double-opening strategy paved the way for national initiatives like the GWD, and later the BRI. ${ }^{525}$ Furthermore, as the GWD strategy developed and unfolded through the dissemination of numerous reports, it became clear that Xinjiang would play a pivotal role in its success.

\section{Xinjiang and the Great Western Development Strategy}

On the surface, Xinjiang is unique among western provinces in that it maintained a higher GDP per capita than its neighbors throughout the 1990s. ${ }^{526}$ Additionally, the province compared very favorably to its western peers in the proportion of its population

\footnotetext{
Victor Shih, "Development, the Second Time Around: The Political Logic of Developing Western China," Journal of East Asian Studies 4(3), 2004, p. 427-451

${ }^{525}$ Nicolas Becquelin, “Staged Development in Xinjiang,” The China Quarterly 178, 2004, p. 358

526 See: Nicolas Becquelin, "Staged Development in Xinjiang," The China Quarterly 178, 2004, p. 359; Qunjian Tian, "China Develops its West: Motivation, Strategy and Prospect," Journal of Contemporary China 13(41), 2004, p. 618-619
} 
that received higher education during this period. ${ }^{527}$ However, looking closely, these positive statistics obscured a growing problem within Xinjiang. Although Xinjiang's GDP per capita continued to increase, the north-south divide persisted. As a result, the north, dominated by Han settlers and migrants, enjoyed the majority of the economic benefits from the numerous development campaigns. ${ }^{528}$ The south, on the other hand, despite improvement in living conditions, continued to suffer from lower standards of living compared with the north, thus making it one of the poorest areas in the country. In fact, the majority of individuals officially classified as "poor" in Xinjiang came from minority ethnic groups. ${ }^{529}$ This disparity was a growing concern for the CCP since it was in the poorest areas of Xinjiang that much of the separatist and terrorist activities perpetrated by minority groups occurred..$^{530}$

Regarding education, there were growing concerns that the cost of education in the province was increasing, thus making it more difficult for minorities to afford higher education. Additionally, Uyghur and other minorities in Xinjiang continued to face difficulties obtaining employment in the province. ${ }^{531}$ In many ways, this was connected to the continued influx of Han settlers and migrant workers who were able to find

\footnotetext{
${ }^{527}$ Qunjian Tian, “China Develops its West: Motivation, Strategy and Prospect," Journal of Contemporary China 13(41), 2004, p. 632-633

${ }^{528}$ Nicolas Becquelin, “Xinjiang in the Nineties,” The China Journal 44, 2000, p. 68-69

${ }^{529}$ Nicolas Becquelin, "Staged Development in Xinjiang," The China Quarterly 178, 2004, p. 372

530 "East Turkestan" Terrorist Forces Cannot get Away with Impunity," Information Office of the State Council, January 21, 2002, http://www.china.org.cn/english/2002/Jan/25582.htm

${ }^{531}$ Nicolas Becquelin, “Staged Development in Xinjiang,” The China Quarterly 178, 2004, p. 375
} 
employment in the more developed economic sectors in Xinjiang due to higher levels of education and institutional racism. There were also concerns that Xinjiang's economy continued to be dominated by State-Owned Enterprises (SOE) ${ }^{532}$ This meant that the provincial economy was largely dependent on a number of firms that were not economically viable and were a massive drain on central resources. Reforming the SOEs was an important component of the reform period in the 1990s in order to prepare the PRC for membership in the World Trade Organization. It was not a coincidence that Jiang announced the GWD strategy at a meeting focused on the reform of the SOEs. Xinjiang's economic dependence on SOEs also indicated that efforts to open up the province to FDI during the 1990s had had limited success. All of these problems indicated that despite favorably comparing to its western neighbors at a macro level, Xinjiang continued to be plagued by social and economic problems that could undermine its stability and the CCP's control of the province.

Xinjiang was a key component of the GWD strategy. That much is evident in the narrative contained in the multiple reports and the types of infrastructure projects that were announced. The goal of consolidating "the unity of ethnic groups" and ensuring "border safety and social stability and promote social progress," expressed in the 2002 plan clearly alluded to the restive minorities in Xinjiang and the need to more effectively integrate them and improve their living standards in order to promote social stability. Furthermore, the importance of the Eurasian Continental Landbridge in the GWD strategy as a means to connect major cities and foster economic activity to adjacent areas revealed Xinjiang's

\footnotetext{
${ }^{532}$ Qunjian Tian, "China Develops its West: Motivation, Strategy and Prospect," Journal of Contemporary China 13(41), 2004, p. 626
} 
centrality for the CCP's domestic state-building and Eurasian region-building efforts. For example, the landbridge would connect coastal provinces to the interior and, eventually, Eurasia. It would also facilitate national integration imperatives and open the west to greater economic activity abroad. Furthermore, the announcement of infrastructure projects that sought to transfer natural gas as well as electricity to coastal provinces meant that Xinjiang's wealth in natural resources, particularly hydrocarbons, played a prominent role in the GWD strategy. Lastly, it was clear that the PRC was interested in Central Asian energy in order to meet growing domestic energy demands. This meant that Xinjiang would serve as the transit hub for any energy infrastructure that would feed the Chinese market, thus illustrating its strategic position.

There was another important reason why Xinjiang played a pivotal role in the GWD strategy. Because the province possessed vital resources, was strategically located, but was also considered the source of significant social unrest, the $\mathrm{CCP}$ exercised a greater degree of control in Xinjiang than in other provinces. This was evidenced by the limited power that was granted to minorities, especially Uyghurs, in the government and the party, compared to other minority autonomous regions in China. Additionally, the critical role that the XPCC played in political control and economic development of Xinjiang, coupled with its direct administration by the State Council, was an indication of the degree of control that the center exercised in the province. However, since many of the Party officials in Xinjiang were dispatched from the center, they had closer ties to officials in Beijing. As a result, they were able to lobby effectively for Xinjiang's pivotal position in the GWD 
strategy. ${ }^{533}$ This was explicitly illustrated by Abdulahat Abdurixit, Xinjiang's Chairman, when he stated that "the main leaders have clearly pointed out that the top priority should be given to Xinjiang during the western development." ${ }^{\text {} 54}$

As previously indicated, the GWD strategy was a state-building initiative that mirrored much of the same goals that were proposed in Xinjiang's double-opening strategy. It sought the effective integration of western provinces, particularly those with significant or majority proportion of ethnic minorities, into the rest of the country. This integration imperative was part of a long-running state-building effort that was dominated by a security-development nexus logic. In other words, there was a need to improve the economic condition in underdeveloped western regions, where a large minority population resided, in order to promote social stability. Likewise, stability was needed to galvanize economic development. In this case the CCP presented itself as the provider of stability and economic development. It was also evident that development was pursued primarily through infrastructure projects that not only created jobs and better investment conditions, but also increased state capacity and the Party's ability to exercise control. Thus, infrastructure had a political, economic, and social function.

In addition to domestic integration, the state-building project also possessed an international component. The western region was not proximate to major established international supply chains. Linking its western provinces to the coast might help integrate the national economy, but it did not address the disadvantages in competitiveness that the former possessed due to their remoteness. This meant that even if the western provinces

\footnotetext{
${ }^{533}$ Nicolas Becquelin, "Staged Development in Xinjiang," The China Quarterly 178, 2004, p. 362-363

${ }^{534}$ Ibid. p. 362
} 
could access international markets through their coastal counterparts, they would remain in a condition of dependency and their ability to attract FDI would remain limited at best. As a result, the CCP realized that the development of the western provinces, especially Xinjiang, needed greater access to Eurasian markets in order to develop new supply chains and attract FDI. Furthermore, as the tenth five-year plan indicated, establishing these new supply chains was a fiscal necessity due to the fact that the GWD strategy could not be underwritten solely by the central government. Concerns over the capacity of the state to single-handedly fund the GWD strategy were exacerbated by the fact that Xinjiang, despite its natural wealth, was, and continues to be, a financial drain on the state. In other words, linking Xinjiang to Eurasian markets and attracting FDI were important considerations for central authorities. Furthermore, the CCP's concern over the three evils and their potential to undermine its authority and control in Xinjiang meant that it needed to look to its western neighbors in order maintain stable relations and secure continued cooperation. This meant that the $\mathrm{CCP}$ correlated stability in Xinjiang with stability in Eurasia, especially in Central Asia, Afghanistan and Pakistan.

Having established a stable relationship with the Shanghai Five, the PRC sought to strengthen and deepen this relationship. Thus, much like the GWD strategy which built on the initial successes of the double-opening strategy, CCP officials sought to build on the success of the Shanghai Five format in order to strengthen political, economic, and social links with the group as well as other Eurasian states. Of particular importance was the growing relevance of the three evils, especially in the context of the increasing frequency of attacks by "East Turkestan" terrorist forces, as Chinese authorities labeled the different separatist Uyghur groups, as well as the global war on terror after the September 11, 2001 
attacks in the United States. ${ }^{535}$ Additionally, China's need to diversify its domestic energy mix as well as the sources of energy imports meant that Eurasian states presented a natural place for investment in the hydrocarbon sector. As a result, the platform of the Shanghai Five, and its successor, the Shanghai Cooperation Organization, played a vital role in the success of the GWD strategy and the CCP's state-building project. In fact in 2000, during the last Shanghai Five summit at Dushanbe, Tajikistan, Jiang Zemin called for the "active participation of Russia and the various Central Asian countries in the development of China's western region." 536 This meant that in this second phase, the PRC was focused on consolidating the gains made through the Shanghai Five and institutionalizing the informal framework in order to further legitimize its engagement in Eurasian affairs. Furthermore, the expansion of state-building imperatives meant an expansion of the region-building project. This meant that the region-building project would widen its scope of cooperation and expand its geographical boundaries.

\section{Institutionalizing the "Shanghai Five"}

The Shanghai Five summits from 1996-2000 served as the fora for confidencebuilding between the PRC, the Russian Federation, Kazakhstan, Kyrgyzstan, and Tajikistan. As indicated in the previous chapter, it was through these meetings that the

\footnotetext{
${ }^{535}$ See: "Terrorist Activities Perpetrated by "East Turkestan" Organizations and their Links with Osama Bin Laden and the Taliban," Permanent Mission of the People's Republic of China to the UN, November 29, 2001, http://www.china-un.org/eng/zt/fk/t28937.htm; "East Turkestan" Terrorist Forces Cannot get Away with Impunity," Information Office of the State Council, January 21, 2002, http://www.china.org.cn/english/2002/Jan/25582.htm

536 Mary Burdman, “'Shanghai Five' Summit Offers Eurasia New Strategic Outlook," Executive Intelligence Review 27(29), 2000, p. 46, http://www.larouchepub.com/eiw/public/2000/eirv27n2920000728/eirv27n29-20000728_044-shanghai_five_summit_offers_eura.pdf
} 
"Treaty on Deepening Military Trust in Border Regions" and the "Treaty on Reduction of Military Forces in Border Regions" were signed in Shanghai (1996) and Moscow (1997) respectively. Additionally, the summits at Almaty (1998) and Bishkek (1999) provided the opportunity for the PRC to press the issue of the three evils more prominently and begin to socialize its dialogue partners into cooperating on this front. Finally, in 2000, the Shanghai Five met in Dushanbe, Tajikistan for what became their last meeting before the formation of the Shanghai Cooperation Organization. This last meeting, however, was critical because it served as the catalyst for expanding the scope of the Shanghai Five mechanism.

Although the Shanghai Five was primarily initiated for the purposes of fostering mutual trust among the participant states and solving the issue of demilitarization along the border, it had become clear that there was a need to expand its agenda. This was already evident in China's efforts to secure the cooperation of the other four states regarding the three evils at the Almaty and Bishkek summits. In fact, this was an issue that would remain central to the Dushanbe summit. During the summit, Jiang Zemin argued that the Shanghai Five could not "overlook the disrupting and sabotaging factors coming from within and outside of the five-nation region that are threatening peace and stability of the region." 537 So, at Dushanbe, the agenda was formally expanded to not only continuing confidencebuilding efforts and cooperating on the three evils, but also "politics, security, diplomacy, as well as trade-economic, cultural-humanitarian and other areas." ${ }^{\circ 38}$

\footnotetext{
537 “Jiang: Perfecting 'Shanghai Five' Mechanism," People's Daily, July 5, 2000, http://en.people.cn/english/200007/05/eng20000705_44747.html

538 "History of the Development of the SCO," China Daily, June 12, 2006, http://www.chinadaily.com.cn/china/2006-06/12/content_6020347.htm
} 
In addition to the expansion of the Shanghai Five's scope, this summit also marked another set of important developments. The first was that Islam Karimov, President of Uzbekistan (1991-2016), was invited to the summit to observe the discussions. ${ }^{539}$ This opened the door for Uzbekistan's entry into the SCO the following year. The second was the focus on a collective discourse that centered on the principle of non-interference between the member states, but more importantly, from outside forces. To that end, the states "oppose[d] intervention in other countries' internal affairs on the pretexts of 'humanitarianism' and 'protecting human rights,' and supported the efforts of one another in safeguarding the five countries' national independence, sovereignty, territorial integrity, and social stability." 540 The third was the recognition of structural changes that, according to the leaders present, were leading to the emergence of a multipolar international system. ${ }^{51}$ This development harked back to the "Russian-Chinese Joint Declaration on a Multipolar World and the Establishment of a New International Order" signed between the PRC and the Russian Federation during the 1997 summit in Moscow. Through this declaration both parties sought the promotion of a multipolar world in which the principles of sovereignty, territorial integrity, mutual non-aggression, non-interference in each other's

\footnotetext{
${ }^{539}$ Ibid.

540 "Spotlight: "Shanghai Five": A Paradigm Mechanism for Peace, Development at Border Areas," Xinhuanet, April 14, 2016, http://www.xinhuanet.com/english/2016-04/14/c_135279213.htm

${ }^{541}$ See: "Vladimir Putin Took Part in a Summit of the Shanghai Five Heads of State," President of Russia, July 5, 2000, http://en.kremlin.ru/events/president/news/38289; "Declaration of Shanghai Cooperation Organization," Embassy of the People's Republic of China in the Republic of Turkey, June 15, 2001, http://www.fmprc.gov.cn/ce/cetur/eng/zt/shhzzz/t162011.htm
} 
internal affairs, and peaceful coexistence, were respected. ${ }^{542}$ These principles were drawn directly from China's "Five Principles of Peaceful Coexistence" that originated in a SinoIndian agreement in $1954 .{ }^{543}$

The re-emergence of the discussion of multipolarity and non-interference during the Dushanbe summit represented a continuation of the efforts by the PRC, as well as those of the Russian Federation, to drive a global discourse that not only provided the PRC with a measure of normative appeal in the context of perceived American hegemony in the global south, but also represented an effort to insulate themselves from criticism regarding their domestic affairs. The last development of this summit was that it marked the first effort to formally institutionalize the Shanghai Five mechanism. This was done through the establishment of a "Council of National Coordinators" that was intended to serve as the platform for regularized formal cooperation efforts by the five-member states. ${ }^{544}$ As a result, the informal grouping began to acquire the characteristics of a formal institution, one that would facilitate the PRC's emergence as a pivotal player in Eurasian affairs.

\footnotetext{
542 "Russian-Chinese Joint Declaration on a Multipolar World and the Establishment of a New International Order," United Nations General Assembly A/52/153-S1997/384, April 23, 1997, http://www.un.org/documents/ga/docs/52/plenary/a52-153.htm

543 “Agreement between the Republic of India and the People's Republic of China on Trade and Intercourse between the Tibet Region of China and India," signed in Beijing April 29, 1954, p. 70, https://treaties.un.org/doc/publication/unts/volume\%20299/v299.pdf

${ }^{544}$ Bates Gill, "Shanghai Five: An Attempt to Counter U.S. Influence in Asia?" Brookings, May 1, 2001, https://www.brookings.edu/opinions/shanghai-five-an-attempt-to-counter-u-s-influence-in-asia/
} 


\section{The Shanghai Cooperation Organization}

The Shanghai Cooperation Organization emerged from the Shanghai Five mechanism. It formalized the meetings of the group, and began the process of institutionalizing a number of important norms that were collective shared. Additionally, as an institution the SCO helped cement and legitimate the PRC's continued presence and engagement in Eurasia. On June 14, 2001, the heads of state of the Shanghai Five group met in Shanghai, marking the return of the group to its place of origin. At this summit, the group voted to formally include Uzbekistan as a member. As indicated above, Karimov had attended the Dushanbe summit in the summer of 2000, and on January 2001, expressed interest in becoming a full member of the Shanghai Five mechanism. ${ }^{545}$ Uzbekistan's entry into the group was the first expansion of the group and marked the transition from the Shanghai Five to the SCO. Following the ascension of Uzbekistan, the heads of state signed the "Declaration on the Establishment of the Shanghai Cooperation Organization," on June 15, 2001. This declaration formally established the SCO, thus upgrading the Shanghai Five mechanism to a "higher level of cooperation" that would allow the member states to make more "effective use of emerging possibilities" and address "new challenges and threats.",546

The rationale for continued cooperation under the upgraded mechanism of the SCO is directly connected to key themes discussed in past meetings, especially the Dushanbe summit. Of particular importance was a shared consensus regarding systemic structural

\footnotetext{
545 "Joint Statement by the Heads of State of the Republic of Kazakhstan, the People's Republic of China, the Kyrgyz Republic, the Russian Federation, the Republic of Tajikistan, the Republic of Uzbekistan," The Shanghai Cooperation Organization, June 14, 2001, http://eng.sectsco.org/documents/

546 "Declaration on the Establishment of the Shanghai Cooperation Organization," The Shanghai Cooperation Organization, June 15, 2001, p. 1, http://eng.sectsco.org/documents/
} 
changes that were resulting in the emergence of a multipolar international system, one marked by greater economic and technological globalization. Additionally, the SCO incorporated the expanded agenda for cooperation that was introduced at the Dushanbe meeting, thus encouraging member states to increase cooperation in the "political, trade, economic, scientific, technical, cultural, educational, energy, transport, environmental and other fields. ${ }^{{ }^{547}}$ Cooperating in these fields would allow the member countries to maintain peace, security, and stability in the region while establishing a new, democratic, just, and rational, international political and economic order. ${ }^{548}$ It is evident from this narrative that cooperation in these fields was envisioned as a process that would lead to greater stability and development, and facilitate the emergence of the multipolar international order that was a central objective of the PRC and the Russian Federation dating back to their joint agreement in 1997.

In addition to the shared belief in the emergence of a multipolar international order and professed efforts to expand cooperation to other important fields in order to foster stability and development, the declaration establishing the SCO also enshrined a number of important norms and principles which had been, until that point, informally adhered to. The first of these norms and principles was encapsulated in what came to be labeled the "Shanghai Spirit." The Shanghai Spirit referred to mutual trust, mutual benefit, equality, joint consultations, as well as respect for cultural diversity and the aspiration for collective development. ${ }^{549}$ It was through these principles that the Shanghai Five members were able

\footnotetext{
${ }^{547}$ Ibid. p. 1-2

${ }^{548}$ Ibid. p. 2
} 
to make progress in their confidence-building mechanisms throughout the 1990s, thus, incorporating them into the SCO would provide a proven framework for future cooperation. Along with the Shanghai Spirit, the Five Principles of Peaceful Coexistence were incorporated into the declaration. Doing so, brought the declaration in line with the United Nations Charter, and continued to expand on the normative capacity of the PRC. Lastly, the three evils were incorporated into the declaration, once again demonstrating the successful socialization of China's neighbors into its securitization narrative. In fact, the first document signed after the establishment of the SCO was "The Shanghai Convention on Combating Terrorism, Separatism and Extremism” on June 15, 2001. 550

Although the SCO has been criticized for being ineffective, ${ }^{551}$ it clearly has served as a useful platform for its members to address important challenges. For example, the organization provided an avenue for Central Asian states to bridge their bilateral frictions as well as receive technical and material support from the SCO's major players: the PRC and the Russian Federation. Furthermore, through the SCO, the challenge posed by the transnational nature of the three evils could be more effectively managed. ${ }^{552}$ This was

\footnotetext{
549 Ibid.

550 "The Shanghai Convention on Combating Terrorism, Separatism and Extremism," The Shanghai Cooperation Organization, June 15, 2001, p. 1-10, http://eng.sectsco.org/documents/

${ }^{551}$ See: Jim Nichol, “Central Asia’s Security: Issues and Implications for U.S. Interests,” Congressional Research Service, March 11, 2010, p. 19, https:/fas.org/sgp/crs/row/RL30294.pdf; Charles E. Ziegler, "Central Asia, the Shanghai Cooperation Organization, and American Foreign Policy from Indifference to Engagement," Asian Survey 53(3), 2013, p. 486; Dina Tokbaeva, "Shanghai Cooperation Organization: Paper Tiger of Sleeping Dragon?” Institute for War \& Peace reporting, September 26, 2016, https://iwpr.net/global-voices/shanghai-cooperation-organisation-paper-tiger

552 Alyson J.K. Bailes and Pal Dunay, "The Shanghai Cooperation Organization as a regional security institution," in The Shanghai Cooperation Organization, eds. Alyson J.K. Bailes, Pal Dunay, Pan Guang, and Mikhail Troitskiy (Stockholm: SIPRI Policy Paper 17, 2007), p. 16
} 
recognized as a core mission for the organization by all members but was considered of utmost importance by the PRC since it secured the cooperation of its western neighbors against separatist groups in Xinjiang. As a result, despite criticism over its inability to respond to the domestic challenges of some of its neighbors as well as the fact that many of its accomplishments occurred through bilateral efforts as opposed to multilateralism, ${ }^{553}$ the SCO has continued to possess intrinsic value, especially for the PRC. The organization provides the PRC with the platform to externalize its securitization of the three evils to its western neighbors, facilitate domestic policies of state-building and control, as well as legitimate its deepening engagement in Eurasian affairs. ${ }^{554}$ In other words, while scholars and analysts may question the effectiveness of the SCO, what matters is that for the PRC this organization has been a vehicle through which it can achieve domestic security and development objectives by ensuring political cooperation and establishing the foundations for greater economic cooperation with its western neighbors.

\section{The Three Evils and the Shanghai Cooperation Organization}

As previously indicated, the "Declaration on the Establishment of the Shanghai Cooperation Organization" and the "The Shanghai Convention on Combating Terrorism, Separatism and Extremism," both signed on June 15, 2001, highlighted the importance of

\footnotetext{
553 See: Alexander Cooley, Great Game, Local Rules: The New Great Power Contest in Central Asia (Oxford: Oxford University Press, 2012), p. 78; Dina Tokbaeva, "Shanghai Cooperation Organization: Paper Tiger or Sleeping Dragon? Institute for War \& Peace Reporting, September 26, 2016, https://iwpr.net/global-voices/shanghai-cooperation-organisation-paper-tiger

554 Jong-Dong Yuan, "China's Role in Establishing and Building the Shanghai Cooperation Organization (SCO)," Journal of Contemporary China 19(67), 2010, p. 855-869
} 
the three evils in the establishment of the SCO. These three evils were later officially enshrined under Article One in the SCO charter and the "Agreement on Regional AntiTerrorist Structure between the Member States of the Shanghai Cooperation Organization,” on June 7, 2002. ${ }^{555}$ These agreements play an important role in China's efforts to exert effective control in places like Xinjiang. Evidence of this can be seen from the repatriation of Uyghur activists in Kazakhstan and Kyrgyzstan as well as curbing the political participation and activism of the Uyghur diaspora throughout Central Asia, something that began after the establishment of the Shanghai Five mechanism but has become institutionalized practice since the formation of the SCO. Part of this institutionalization occurred after the establishment of the Regional Anti-Terrorist Structure (RATS) in Tashkent, Uzbekistan in 2004, and the signing of the "Concept of Cooperation between SCO Member States in Combating Terrorism, Separatism, and Extremism," on June 5, 2005.

The establishment of the Regional Anti-Terrorist Structure provided member states with the mechanism to build capacity for fighting the three evils as well as the forum to share intelligence and information regarding illicit activities by groups and individuals that have been identified by SCO members. ${ }^{556}$ It did this by assisting in the coordination and collaboration between “the Parties' competent agencies in combating terrorism, separatism,

\footnotetext{
555 See: "Charter of the Shanghai Cooperation Organization," The Shanghai Cooperation Organization, June 7, 2002, p. 2, http://eng.sectsco.org/documents/; "Agreement on Regional Anti-Terrorist Structure between the Member States of the Shanghai Cooperation Organization," The Shanghai Cooperation Organization, June 7, 2002, http://eng.sectsco.org/documents/

556 “Agreement on Regional Anti-Terrorist Structure between the Member States of the Shanghai Cooperation Organization," The Shanghai Cooperation Organization, June 7, 2002, http://eng.sectsco.org/documents/
} 
and extremism as defined in the Convention." ${ }^{557}$ In addition to the RATS, the "Concept of Cooperation between SCO Member States in Combating Terrorism, Separatism, and Extremism," required SCO signatories to reciprocally recognize "a terrorist, separatist, or extremist act regardless of whether the legislation of SCO member states includes a corresponding act in the same category of crimes or whether the act is described using the very same terms." 558 This is an important point since despite official claims that the SCO follows established international norms and laws, particularly those set by the UN, the framework outlined by the "Concept of Cooperation" does not comply with international standards. Rather than clearly defining terrorism, separatism, and extremism, as well as identifying the conceptual differences between them, the SCO allows each member to apply its domestic definition. This results in the problem of double criminality, which is a basic rule of international law on extradition. In essence, the rule of double criminality holds that an act cannot be extraditable unless it constitutes a crime in the laws of both the requesting and the requested state. ${ }^{559}$ By requiring reciprocity of recognition, while simultaneously allowing for multiple local definitions, this 2005 agreement makes extradition of targeted individuals easier.

Although an effort was made in 2009 to develop a single definition for terrorism through the "Convention of Counter-Terrorism of the Shanghai Cooperation Organization,"

\footnotetext{
${ }^{557}$ Ibid. p. 2

558 "Concept of Cooperation between SCO Member States in Combating Terrorism, Separatism, and Extremism," in Counter-Terrorism and Human Rights: The Impact of the Shanghai Cooperation Organization (Human Rights Watch in China, 2011), p. 168

559 "Shanghai Cooperation Organization: A Vehicle for Human Rights Violation," International Federation for Human Rights, 2012, p. 9-10, https://www.fidh.org/IMG/pdf/sco_report.pdf
} 
it has been criticized for lacking precision. ${ }^{560}$ As human rights groups have indicated, linking terrorism to an "ideology of violence," as the "Convention of Counter-Terrorism" does, essentially connects separatism and extremism to terrorism. In other words, there is little conceptual distinction between the three evils since they are considered part of the same package. ${ }^{561}$ This means that beyond merely externalizing the three evils through the SCO, the PRC has also externalized its understanding of the three evils, something that demonstrates its normative power. Accomplishing this feat facilitates the CCP's statebuilding efforts by strengthening its ability to exercise control of Xinjiang and minorities along its western frontier by ensuring that domestic policies that may be internationally perceived as repressive will be supported by SCO member states. Consequently, the practice of extraditing individuals who are suspected of terrorism, separatism, and extremism has become institutionalized within the framework of the SCO.

America's global war on terror has also facilitated China's state-building efforts and its ability to exercise control of Xinjiang by providing an avenue for legitimizing domestic policies and by delegitimizing separatist elements in the province by framing their activities within the global terrorist network. ${ }^{562}$ In other words, CCP leadership has co-opted the global war on terror as a vehicle to cement its authority in Xinjiang. However,

\footnotetext{
560 "The Convention of Counter-Terrorism of the Shanghai Cooperation Organization," in CounterTerrorism and Human Rights: The Impact of the Shanghai Cooperation Organization (Human Rights Watch in China, 2011), p. 196

561 "Shanghai Cooperation Organization: A Vehicle for Human Rights Violation," International Federation for Human Rights, 2012, p. 9-10, https://www.fidh.org/IMG/pdf/sco_report.pdf

${ }^{562}$ Brian Fishman, "Al-Qaeda and the Rise of China: Jihadi Geopolitics in a Post-Hegemonic World," The Washington Quarterly 34(3), p. 53
} 
in order to do this effectively, the PRC needed a measure of cooperation with the United States. On the day of the September 11, 2001, attacks, Jiang Zemin messaged President George W. Bush to express his condolences and condemn the terrorist attacks. The following day during a phone conversation, Jiang promised Bush that China would cooperate with the US in its fight with terrorism. It proved this commitment on the same day when China voted in favor of UN resolution 1368 condemning terrorism. ${ }^{563}$ Foreign Minister Tang Jiaxuan (1998-2003) expressed similar pledges during his phone conversation with State Secretary Colin Powell on September 13, 2001, and reiterated China's commitment to cooperation during his visit to the United States on September 2021 to Secretary Powell, Vice President Cheney, and President Bush. ${ }^{564}$

Beyond fulfilling obligations of diplomatic courtesy, this outreach and expressed support was part of an effort to get the United States to classify the East Turkestan Islamic Movement (ETIM), as well as other groups broadly incorporated into the umbrella term "East Turkestan Forces," as terrorist groups. In order to accomplish this the CCP began releasing documents that linked these groups to terrorist affiliations and activities. On November 21, 2001, China released a report outlining a number of terrorist acts committed by various East Turkestan groups as well as their connection to Osama bin Laden and the Taliban. ${ }^{565}$ The report claimed that Hasan Mahsum was the leader of ETIM and that the

\footnotetext{
${ }^{563}$ Shirley Kan, "U.S.-China Counter-Terrorism Cooperation: Issues for U.S. Policy," CRS Report for Congress, December 7, 2004, p. 1, https://fas.org/irp/crs/RS21995.pdf

${ }^{564}$ Alice L. Miller, “An Uneasy Alliance,” Hoover Institution No. 3, July 30, 2002, https://www.hoover.org/research/uneasy-alliance

565 "Terrorist Activities Perpetrated by "East Turkestan" Organization and their Links with Osama Bin Laden and the Taliban," Permanent Mission of the People's Republic of China to the UN, November 21, 2001, http://www.china-un.org/eng/zt/fk/t28937.htm
} 
group was a major component of the terrorist network headed by Osama bin Laden. It also claimed that Mahsum was based in Kabul, Afghanistan and carried an Afghan passport issued by the Taliban. More importantly, however, the report identified training camps that were linked to bin Laden's Al-Qaeda network, the Taliban, and the Uzbek Islamic Movement, as well as the money trail between bin Laden and ETIM. ${ }^{566}$

This report was followed up on January 21, 2002 with a white paper from the State Council. The white paper represented the first instance of a detailed report on terrorist attacks within China. It is relevant on two accounts: (1) it presents a historiography of China's control of Xinjiang; (2) it itemizes a series of attacks, thus providing insight into the types of violent incidents that have occurred within China. ${ }^{567}$ Regarding the first account, the white paper indicates "after the establishment of a frontier command headquarters (duhufu) in the Western Region by the Han Dynasty in 60 B.C., Xinjiang became a part of Chinese territory. From that time on, the central government has never ceased jurisdiction over Xinjiang." ${ }^{568}$ It contends that "East Turkestan," the name of two separate republics during the early $20^{\text {th }}$ century, is a political concept that was introduced by colonial powers during the $19^{\text {th }}$ century in order to dismember China and undermine her sovereignty. ${ }^{569}$ This point was aimed at effectively delegitimizing the Uyghur's historical

\footnotetext{
566 Ibid.

567 "East Turkestan" Terrorist Forces Cannot get Away with Impunity," Information Office of the State Council, January 21, 2002, http://www.china.org.cn/english/2002/Jan/25582.htm

568 Ibid.

569 Ibid.
} 
claims to an independent political entity in the area of modern day Xinjiang. On the second account, the white paper claims that from 1990-2001 "East Turkestan" forces inside and outside of Chinese territory have been responsible "for over 200 terrorist incidents in Xinjiang, resulting in the deaths of 162 people of all ethnic groups, including grass-roots officials and religious personnel, and injuries to more than 440 people." 570 These reports allowed China to establish the terrorist bona fides of ETIM and other East Turkestan groups and frame their actions, terrorist or otherwise, in the context of Washington's war on terror.

Although American military presence in Afghanistan presented a challenge for China, particularly as US efforts to establish basing agreements with SCO countries were perceived as a form of encirclement, ${ }^{571}$ Chinese cooperation with the US in the war on terror had tangible benefits. After months of bilateral discussions, the US government placed ETIM on one of its three terrorist blacklists on September 3, 2002, through Executive Order 13224. This Executive Order placed ETIM on the Treasury blacklist. Although this step is considered largely symbolic since the group is not believed to have a significant financial footprint in the United States. ${ }^{572}$ This success was followed by the UN designation of ETIM as a terrorist group under Security Council Resolutions 1267 and 1390 on September 11, 2002. The designation was secured after the US supported Chinese,

\footnotetext{
${ }^{570}$ Ibid.

571 See: Alice L. Miller, “An Uneasy Alliance,” Hoover Institution No. 3, July 30, 2002, https://www.hoover.org/research/uneasy-alliance; Shirley Kan, "U.S.-China Counter-Terrorism Cooperation: Issues for U.S. Policy," CRS Report for Congress, December 7, 2004, p. 4, https://fas.org/irp/crs/RS21995.pdf; Alexander Cooley, Great Game, Local Rules: The New Great Power Contest in Central Asia (Oxford: Oxford University Press, 2012), p. 81

572 J. Todd Reed and Diana Raschke, The ETIM: China's Islamic Militants and the Global Terrorist Threat (Santa Barbara: Preager, 2010), p. 103
} 
Afghan, and Kyrgyz delegation requests. This was an important accomplishment since the UN designation requires all member states to freeze ETIM's financial assets, ban its travel, and prohibit the transfer of any military equipment, technical advice, or training to members of the group. ${ }^{573}$ On April 29, 2004, the US State Department placed ETIM on the Terrorist Exclusion List, effectively putting the group on its second terrorist blacklist by enforcing an immigration ban. ${ }^{574}$ However, the US government has not placed ETIM on its highest profile blacklist, the State Department's Foreign Terrorist Organization (FTO). This may be due to the fact that Executive Orders do not require the same burden of proof and judicial review process that is required for placing a group in the FTO, although, as a practical matter, this does not impact how Washington would treat the group. ${ }^{575}$ Perhaps one of the best examples of China's successful efforts to lobby the US was being granted permission by the US government to interrogate the twenty-two Uyghur detainees that were being held at the detention camp in Guantanamo Bay, Cuba on 2002. ${ }^{576}$ However, despite these successes, Chinese authorities have been unable to get the US to extradite its Uyghur detainees to China after their release from the detention camp. ${ }^{577}$ Despite this

\footnotetext{
${ }^{573}$ Ibid. p. 104

${ }^{574}$ Ibid. p. 103

575 Andrew Scobell, "Chinese Foreign Policy and the War on Terror," The Jamestown Foundation Terrorism Monitor 2(2), May 5, 2005, https://jamestown.org/program/chinese-foreign-policy-and-the-waron-terror/

576 See: Erik Eckholm, "Out of Guantanamo, Uighurs Bask in Bermuda," The New York Times, June 14, 2009, http://www.nytimes.com/2009/06/15/world/americas/15uighur.html; David Leigh, "Guantanamo Files: China Among Regimes Invited to Interrogate Captives," The Guardian, April 24, 2011, https://www.theguardian.com/world/2011/apr/25/guantanamo-files-china-interrogated-prisoners

577 "Devastating Blows: Religious Repression of Uighurs in Xinjiang," Human Rights Watch 17(2), 2005, p. 24-25, https://www.hrw.org/report/2005/04/11/devastating-blows/religious-repression-uighurs-xinjiang
} 
shortcoming, however, the global war on terror has given China a platform to more effectively externalize its securitization of Muslim minorities in Xinjiang, and thus, to strengthen its control of the province.

The PRC has made use of this platform effectively and with assistance from some of its SCO neighbors has sought to bring international legitimacy to its fight against the three evils. For example, on October 14, 2004, General Secretary of the Chinese Communist Party, Hu Jintao (2002-2012), and President of the Russian Federation, Vladimir Vladimirovich Putin (2000-2008, 2012-present), called for international support in their fight against domestic terrorist groups. The joint statement argued that

This statement represented an effort by the PRC to legitimize its domestic policies in Xinjiang, by externalizing its securitization of "East Turkestan" groups operating within or outside Chinese territory. In other words, it was a co-optation of the global war on terror for the purpose of facilitating state-building efforts and legitimizing policies of domestic control. Furthermore, it implies that terrorism and separatism were interchangeable, thus illustrating how the three evils were seen as a package as opposed to three separate concepts clearly defined by law. ${ }^{579}$

\footnotetext{
578 "China and Russia Issue a Joint Statement, Declaring the Trend of the Boundary Line Between the Two Countries Has Been Completely Determined," Ministry of Foreign Affairs of the People's Republic of China, October 14, 2004, http://www.fmprc.gov.cn/eng/wjdt/2649/t165266.htm
} 
The PRC has also found success externalizing its securitization of "East Turkestan" groups to other neighboring states that were not full members of the SCO during this second phase. Unsurprisingly, both of these states, Nepal and Pakistan, border China's most restive provinces in its western frontier: Tibet and Xinjiang respectively. Through negotiations and diplomatic outreach, both countries have extradited Uyghur refugees or individuals suspected of separatism to China. ${ }^{580}$ Pakistan's cooperation in particular has been considered of utmost importance since the CCP suspects that a number of Uyghurs have received religious indoctrination and combat training in Pakistan's tribal areas. ${ }^{581}$ This created tensions between the "all-weather" partners, especially since Indian intelligence reports regularly claimed that the Pakistani Army had directly trained Uyghurs in a camp across the Line of Actual control in the contested region of Jammu and Kashmir in the early 1990s. ${ }^{582}$ However, by the late 1990s Pakistan began addressing China's concerns regarding the status of the Uyghur diaspora residing in Pakistan as well as the targeting of Chinese nationals working in Pakistan by terrorist groups. ${ }^{583}$ This occurred as both countries sought to increase security along their shared border in order to deepen

\footnotetext{
579 "Devastating Blows: Religious Repression of Uighurs in Xinjiang," Human Rights Watch 17(2), 2005, p. 24, https://www.hrw.org/report/2005/04/11/devastating-blows/religious-repression-uighurs-xinjiang

580 "People's Republic of China: Uighurs Fleeting Persecution as China Wages its War on Terror," Amnesty International, July 6, 2004, https://www.amnesty.org/en/documents/ASA17/021/2004/en/

${ }^{581}$ See: P. Stoban, “China's Central Asia Dilemma," Strategic Analysis 22(3), 1998, p. 400; Eric Hyer, "China's Policy Towards Uighur Nationalism," Journal of Muslim Minority Affairs 26(1), 2006, p. 81; See: Yitzhak Shichor, "The Great Wall of Steel: Military and Strategy in Xinjiang," in Xinjiang: China's Muslim Borderland, ed. S. Frederick Starr (Armonk: M.E. Sharpe, 2004), p. 144-145

582 Yitzhak Shichor, "The Great Wall of Steel: Military and Strategy in Xinjiang," in Xinjiang: China's Muslim Borderland, ed. S. Frederick Starr (Armonk: M.E. Sharpe, 2004), p. 144-145

${ }^{583}$ Ibid.
} 
economic cooperation by increasing trade between Xinjiang and Pakistan. In fact, as will be discussed below, Pakistan plays an important role in the Great Western Development strategy not only for its ability act as a gateway to the Indian Ocean and facilitate the economic development in southern Xinjiang, but also for the PRC in general.

Pakistan's partnership and cooperation against the three evils, particularly after the beginning of the global war on terror, has paid dividends for the PRC. On October 2, 2003, the Pakistani Army killed Hasan Mahsum, leader of the East Turkestan Islamic Movement, in a raid along the Afghan-Pakistan border. ${ }^{584}$ The following month both countries signed an extradition treaty, facilitating China's efforts to limit the movement of Uyghur groups into countries with which it shares a border. ${ }^{585}$ Thus, although Chinese nationals have been targeted in Pakistan by terrorist and separatist groups in order to extract concessions from the Pakistani government (knowing that Pakistan relies heavily on its relationship with the PRC) ${ }^{586}$ Beijing has been able to accomplish its goal of obtaining Islamabad's cooperation in its efforts to exercise control of Xinjiang. Having accomplished this goal, the stage was set for Pakistan to play a bigger role in the economic development of China's western regions.

\footnotetext{
584 "Spokesperson's remarks on the Death of Hasan Mahsum, Head of the "East Turkistan Islamic Movement."' Permanent Mission of the People's Republic of China to the UN, December 24, 2003, http://www.fmprc.gov.cn/ce/ceun/eng/fyrth/t57039.htm

585 “People's Republic of China: Uighurs Fleeting Persecution as China Wages its War on Terror," Amnesty International, July 6, 2004, https://www.amnesty.org/en/documents/ASA17/021/2004/en/

${ }^{586}$ Mathieu Duchatel, “The Terrorist Risk and China's Policy Toward Pakistan: Strategic Reassurance and the 'United Front,"” Journal of Contemporary China 20(71), p. 546-547
} 
Beyond facilitating Beijing's control of its Uyghur population by limiting the movement of Uyghurs across borders, the SCO also helps Beijing improve the policing capacity of its members. ${ }^{587}$ This allows China to enhance SCO members' capacity to combat the three evils domestically, something that it hopes will prevent potential spillover of instability into Xinjiang. One way in which the SCO aids the capacity-building efforts of its members, particularly the Central Asian republics, is through military and law enforcement exercises. These exercises focus on developing joint capacity for fighting the three evils. As a result, these exercises run scenarios that combine military and law enforcement personnel in efforts to defend critical sites from terrorist attacks, rescue hostages, and improve the interoperability of participant states. ${ }^{588}$ In addition to aiding the capacity-building efforts of Central Asian republics, these exercises also complement China's efforts to enforce social stability and control in Xinjiang. This is evident from the fact that four out of the thirteen exercises held since 2002 have been staged, at least partially, within Xinjiang. Furthermore, the People's Liberation Army has used the timing of SCO exercises within Xinjiang to conduct further counter-terrorism exercises on its own. ${ }^{589}$

\footnotetext{
${ }^{587}$ Rashid Alimov, "The Role of the Shanghai Cooperation Organization in Counteracting Threats to Peace and Stability," UN Chronicle LIV(3), 2017, https://unchronicle.un.org/article/role-shanghai-cooperationorganization-counteracting-threats-peace-and-security

588 "Military and Law Enforcement Cooperation Between Member States of the Shanghai Cooperation Organization," in Counter-Terrorism and Human Rights: The Impact of the Shanghai Cooperation Organization (Human Rights Watch in China, 2011), p. 331-336

${ }^{589}$ Ibid. p. 328
} 


\section{The Security-Development Nexus and the Shanghai Cooperation Organization}

The nature of the Shanghai Cooperation Organization reflects much of the securitydevelopment nexus logic that underpins Chinese domestic policy. As some scholars have indicated, this represents a more holistic approach to the understanding of security. ${ }^{590}$ This is unsurprising since the SCO's formation was primarily driven by China and is widely considered to be its major driving force ${ }^{591}$ Thus, while the three evils are enshrined as a core pillar of the SCO, so are the calls for addressing their root cause as the CCP understands it: underdevelopment. In fact, even as Jiang Zemin expressed support for America's global war on terror, China's White Paper for National Defense of 2002, cautioned that in fighting terrorism, it was "necessary to address both its symptoms and root cause, and adopt comprehensive measures, especially in solving the question of development. ${ }^{" 592}$

The annual joint declarations by SCO heads of state reveal two important norms that have been advocated by CCP leadership for decades: (1) the linkage of security, stability, and development; (2) and the respect for every country's approach to development. In essence, one illustrates the centrality of the security-development nexus to the SCO while the other opens the door for increasing China's normative appeal. For

\footnotetext{
${ }^{590}$ Stephen Aris, "Shanghai Cooperation Organization: Mapping Multilateralism in Transition No.2," International Peace Institute, 2013, p. 6, https://www.ipinst.org/wpcontent/uploads/publications/ipi_e_pub_shanghai_cooperation.pdf

${ }^{591}$ Pan Guang, "A Chinese Perspective on the Shanghai Cooperation Organization," in The Shanghai Cooperation Organization, eds. Alyson J.K. Bailed, Pal Dunay, Pan Guang, and Mikhail Troitskiy (Stockholm: SIPRI Policy Paper 17, 2007), p. 45

592 "China's National Defense in 2002," Information Office of the State Council, 2002, http://www.china.org.cn/e-white/20021209/VI.htm\#2
} 
example, the 2004 Tashkent declaration stated that "progressive economic development of the Central Asia Region and the neighboring states and meeting the vital needs of their population is a keystone of their stability and security. ${ }^{, 593}$ At the 2005 Astana Summit, the heads of state supported the SCO's role in "strengthening stability and promoting economic development in Central Asia" in addition to promoting the "the right of every nation to its own way of development should be fully guaranteed," an implicit criticism of the liberalnormative approach advocated by the West. ${ }^{594}$ The following year, the SCO celebrated its fifth anniversary at the Shanghai Summit. The declaration of the heads of states expressed support for Central Asian states and "their efforts to safeguard security and stability, maintain social and economic development and improve people's livelihood." 595 Additionally, the Shanghai declaration reiterated that "diversity of civilization and model of development must be respected and upheld." ${ }^{596}$ The most explicit reference to the security-development nexus emerged from the 2007 Bishkek declaration in which the heads of state argued that the growing interdependence between states have made their "security and development indivisible." ${ }^{\text {" } 97}$ This declaration also supported the right of each

\footnotetext{
593 "Tashkent Declaration by Heads of Member States of the Shanghai Cooperation Organization," The Shanghai Cooperation Organization, 2004, http://eng.sectsco.org/documents/

594 "Astana Declaration by Heads of Member States of the Shanghai Cooperation Organization," The Shanghai Cooperation Organization, 2005, http://eng.sectsco.org/documents/

595 "Shanghai Declaration of the Fifth Anniversary of the Shanghai Cooperation Organization, The Shanghai Cooperation Organization, 2006, http://eng.sectsco.org/documents/

${ }^{596}$ Ibid.

597 "Bishkek Declaration by Heads of Member States of the Shanghai Cooperation Organization, The Shanghai Cooperation Organization, 2007, http://eng.sectsco.org/documents/
} 
member state to "independently choose its way of development based on its own historical experience and national specificity." 598

Declarations and other agreements from successive years reiterate these two points. ${ }^{599}$ This indicates that China's externalization of its understanding of the securitydevelopment nexus has become an institutionalized norm within the framework of the SCO. Furthermore, the continued adherence to respecting different forms of development, presents a challenge to the dominant liberal-normative order established by the West. Nevertheless, while evidently appealing for diversity in economic models among SCO members, these statements pave the way for China to present its development model as a legitimate alternative to the Western-led liberal model. It is able to do this more effectively as a result of its demonstrable success in pulling China out of poverty and leading to its emergence as a global power. In other words, China's economic success, provides it with a measure of normative appeal, especially to countries that continue to be dominated by authoritarian single-party systems. ${ }^{600}$

\section{The Expansion of the Eurasian Region-Building Project}

As indicated above, the CCP leadership had become increasingly sensitive to the underdevelopment of its western regions by the turn of the century. The Great Western Development strategy, underpinned by a security-development nexus logic, was the

\footnotetext{
${ }^{598}$ Ibid.

${ }^{599}$ See: “Documents," The Shanghai Cooperation Organization, http://eng.sectsco.org/documents/

${ }^{600}$ Thomas Barker, “The Real Source of China's Soft Power,” The Diplomat, November 18, 2017, https://thediplomat.com/2017/11/the-real-source-of-chinas-soft-power/
} 
outcome of the changing development priorities. It is also evident that the $\mathrm{CCP}$ recognized that in order for the GWD strategy to succeed, the western provinces needed access to Eurasian markets (inside and outside the SCO). Xinjiang, as China's gateway to Eurasia was of strategic importance, thus, its integration into the rest of the country and the ability of the CCP to exercise effective control of the province were crucial. This explains China's efforts to externalize the three evils and its understanding of the security-development nexus, as well as its co-optation of the global war on terror. Furthermore, it demonstrates the importance of the SCO as a platform for the PRC to accomplish these tasks and legitimizing its deepening engagement in Eurasia. Thus, as a region-building project, the SCO not only functions as a vehicle for greater domestic control, but also serves as a springboard for China to access the rest of Eurasia through overland routes.

Throughout the 1990s the PRC, in cooperation with its western neighbors, began to open a series of landports in order to promote trade. ${ }^{601}$ The majority of these landports were located in Xinjiang due to its strategic location and its importance to the Eurasian Continental Landbridge concept that CCP officials had regularly referred to. As the Great Western Development strategy began to pick up pace, the central government intensified investment in the upgrade of the ports, as well as the roads and railways. ${ }^{602}$ By 2010 , there were a total of 15 class-A landports and 11 class-B ports, in additional to two international

\footnotetext{
601 "Xinjiang's Land Ports \& Border Trade," China.org, December 15, 2017, http://www.china.org.cn/english/features/Xinjiang/114777.htm

${ }^{602}$ Qingguo Jia, “The Shanghai Cooperation Organization: China's Experiment in Multilateral Leadership," in Eager Eyes Fixed on Eurasia: Russia and its Eastern Edge, ed. Iwashita Akihiro (Sapporo: Slavic Research Center, Hokkaido University, 2007), p. 116-117
} 
airports, connecting Xinjiang to its western neighbors and beyond. ${ }^{603}$ Of the 15 class-A ports, the most important, 7 connect to Kazakhstan, and 3 connect to Kyrgyzstan, ${ }^{604}$ highlighting their importance to direct cross-border trade ${ }^{605}$ During the first decade of the century, two particular landports emerged as the most critical to China's efforts of increasing economic activity in the west as well as link to other Eurasian states: Alashankou and Horgos. Both of these ports are located on the border with Kazakhstan. Alashankou became a unique landport in China since it was the only class-A port to have integrated railway, highway, and oil pipelines. In 2009, freight turnover at Alashankou reached 23.23 million tons, making it the top landport in China ${ }^{606}$ The following year the freight turnover had reached 25.24 million tons, marking yet another milestone in trade volume for the port. In 2010, Alashankou's warehouse capacity reached 554,000 square meters, which made it the largest indoor container transit warehouse in all of Asia. ${ }^{607}$

Horgos emerged as a unique port during this period due to its rank as the largest highway port in northwest China as well as being a major bridge for China to link with

${ }^{603}$ See: "Xinjiang's Land Ports \& Border Trade," China.org, December 15, 2017, http://www.china.org.cn/english/features/Xinjiang/114777.htm; Ping Chen, Jun Liu, Ran Wei, Yong Liu, "China's Logistic Development in Certain Key Regions," in Contemporary Logistics in China:

Transformation and Revitalization, eds. Bing-lian Liu, Shao-ju Lee, Jian-hua Xiao, Long Wang, and Zhilun Jiao (New York: Springer, 2013), p. 75

${ }^{604}$ Xinjiang's Land Ports \& Border Trade,” China.org, December 15, 2017 , http://www.china.org.cn/english/features/Xinjiang/114777.htm

${ }^{605}$ Zhuangzi Sun, "The Relationship between China and Central Asia," in Eager Eyes Fixed on Eurasia: Russia and its Eastern Edge, ed. Iwashita Akihiro (Sapporo: Slavic Research Center, Hokkaido University, 2007), p. 41-63

${ }^{606}$ Ping Chen, Jun Liu, Ran Wei, Yong Liu, "China's Logistic Development in Certain Key Regions," in Contemporary Logistics in China: Transformation and Revitalization, eds. Bing-lian Liu, Shao-ju Lee, Jian-hua Xiao, Long Wang, and Zhi-lun Jiao (New York: Springer, 2013), p. 75

${ }^{607}$ Ibid. p. 76 
Kazakhstan, Russia, and Western European countries. More importantly, however, as will be discussed below, Horgos is where the critical pipelines connecting Central Asian energy to the Chinese market meet. The opening and upgrading of these numerous landports had a demonstrable effect on the volume of trade between China and its SCO neighbors during this period. By re-establishing transportation links that had been severed by the Sino-Soviet split and had fallen into disrepair, China was paving the way for greater economic development in the western regions as well as providing a platform for economic diversification to Central Asian republics that remained heavily reliant on the Russian Federation for trade.

\section{Escaping the Malacca Dilemma}

Interconnectivity, however, did not end with roads and landport openings. The first decade of the $21^{\text {st }}$ century saw the PRC emerge as the second largest economy in the world. ${ }^{608}$ This meant that Beijing needed greater access to hydrocarbons in order to feed its ever-growing demands for energy. In 1993, China became a net oil importer for the first time due to growing domestic demands and its inability to meet these demands through domestic production. ${ }^{609}$ This made China heavily reliant on energy imports from Southwest Asia and, therefore, susceptible to interruptions of commercial flows on the

\footnotetext{
${ }^{608}$ David Barboza, "China Passes Japan as Second-Largest Economy,” The New York Times, August 15, 2010, http://www.nytimes.com/2010/08/16/business/global/16yuan.html?pagewanted=all

${ }^{609}$ Phillip Andrews-Speed, “China's Energy Policymaking Process and their Consequences," in China's Energy Crossroads: Forging a New Energy and Environmental Balance, eds. Phillip Andrews-Speed, Mikkal E. Herberg, Li Zhidong, and Benjamin A. Shobert, NBR Special Report 47, 2014, p. 3
} 
maritime commons. ${ }^{610}$ This concern, was encapsulated in the "Malacca Dilemma," a term coined by General Secretary Hu Jintao at a speech in a CCP economic work conference on 2003. The dilemma referred to the Malacca Straits which is one of the busiest shipping straights in the world and through which most of China's trade and energy imports traverse (see map 7). During his speech Hu stated that "certain powers have all along encroached on and tried to control navigation through the strait," referring to the US Navy which maintains a constant presence in the straits. ${ }^{611}$ In order to address this strategic vulnerability to its economic and energy security, there was a need to diversify trade and energy routes away from the maritime commons.

In this regard, China's SCO partners have become the most natural partners for energy diversification. Beyond the geographical proximity, a number of SCO countries possess significant hydrocarbon reserves and can also provide an overland link to Southwest Asia, thus bypassing the American-dominated oceans. ${ }^{612}$ While Beijing has been unable to form an energy group under the rubric of the SCO, it has nonetheless been able secure access to vast hydrocarbon resources from the Russian Federation as well as Central Asian republics. However, it is important to note that while the Russian Federation surpasses all SCO members in proven oil and natural gas reserves, it was Central Asia that was more proactively courted by Chinese SOEs during this phase due to the proximity of

\footnotetext{
${ }^{610}$ Christopher Davidson, Persian Gulf and Pacific Asia: From Indifference to Interdependence (New York: Columbia University Press, 2010)

${ }^{611}$ Mark Lanteigne, "China's Maritime Security and the "Malacca Dilemma,"” Asian Security 4(2), 2008, p. 143-144

${ }^{612}$ Mary Burdman, "'Shanghai Five' Summit Offers Eurasia New Strategic Outlook," Executive Intelligence Review 27(29), 2000, p. 44, http://www.larouchepub.com/eiw/public/2000/eirv27n2920000728/eirv27n29-20000728_044-shanghai_five_summit_offers_eura.pdf
} 
their fields as well as the political and economic diversification that this affords Central Asian states. Furthermore, establishing a footprint in Central Asia allows China to eventually access Southwest Asian deposits directly overland. Of the Central Asian republics, Kazakhstan, with which the PRC has established the closest links, possesses 30 billion barrels of proven oil reserves, $12^{\text {th }}$ largest in the world. Additionally, Kazakhstan possess roughly 2.8 trillion cubic meters of proven natural gas reserves, the $15^{\text {th }}$ largest. ${ }^{613}$ Uzbekistan's oil reserves are negligible, however, it possesses the $20^{\text {th }}$ largest proven natural gas reserves at roughly 1.85 trillion cubic meters. ${ }^{614}$ Neither Kyrgyzstan nor Tajikistan have been found to have meaningful proven oil or natural gas reserves for export, although this may be due to the fact that during Soviet times Moscow paid little attention to oil and gas exploration in these small republics, especially since their neighbors and Russia proper were known to have vast quantities.

However, among the Central Asian republics, Turkmenistan is the crown jewel. Although Turkmenistan is not an SCO member due to its declaration of neutrality in 1996, the country possesses vast natural gas reserves, making it an important target for Chinese development goals. ${ }^{615}$ Turkmenistan possesses the $6^{\text {th }}$ largest proven natural gas reserves at roughly 7.5 trillion cubic meters. ${ }^{616}$ Furthermore, Turkmenistan's existing integration

613 “Kazakhstan," CIA World Factbook, February 22, 2018, https://www.cia.gov/library/publications/theworld-factbook/geos/kz.html

614 “Uzbekistan,” CIA World Factbook, February 22, 2018, https://www.cia.gov/library/publications/theworld-factbook/geos/uz.html

615 "Constitutional Law of Turkmenistan on Permanent Neutrality of Turkmenistan," Refworld, January 7 , 1996, http://www.refworld.org/docid/405ab3d14.html

616 “Turkmenistan,” CIA World Factbook, February 22, 2018, https://www.cia.gov/library/publications/theworld-factbook/geos/tx.html 
into Iran's northern energy infrastructure through two pipelines ${ }^{617}$ illustrates the former's potential to link China to the latter through an overland pipeline network. In other words, accessing Turkmenistan not only would provide China much-needed natural gas, but could also potentially serve as the window to Southwest Asia's vast energy resources. However, accessing Central Asian hydrocarbons would require significant investment as well as careful political maneuvering. All of the region's energy infrastructure was integrated into the Russian network as a byproduct of the USSR. This meant that the only markets that Central Asian republics could service with their existing infrastructure were Russia and Western Europe.

\footnotetext{
${ }^{617}$ Bruce Pannier, "Turkmen Exports to Iran a Boom for Both Countries," Radio Free Europe Radio Liberty, January 6, 2010, https://www.rferl.org/a/Turkmen_Gas_Exports_To_Iran_A_Boon_For_Both_Countries/1921933/p1.html?c ontenttype $=1 \#$ relatedInfoContainer
} 


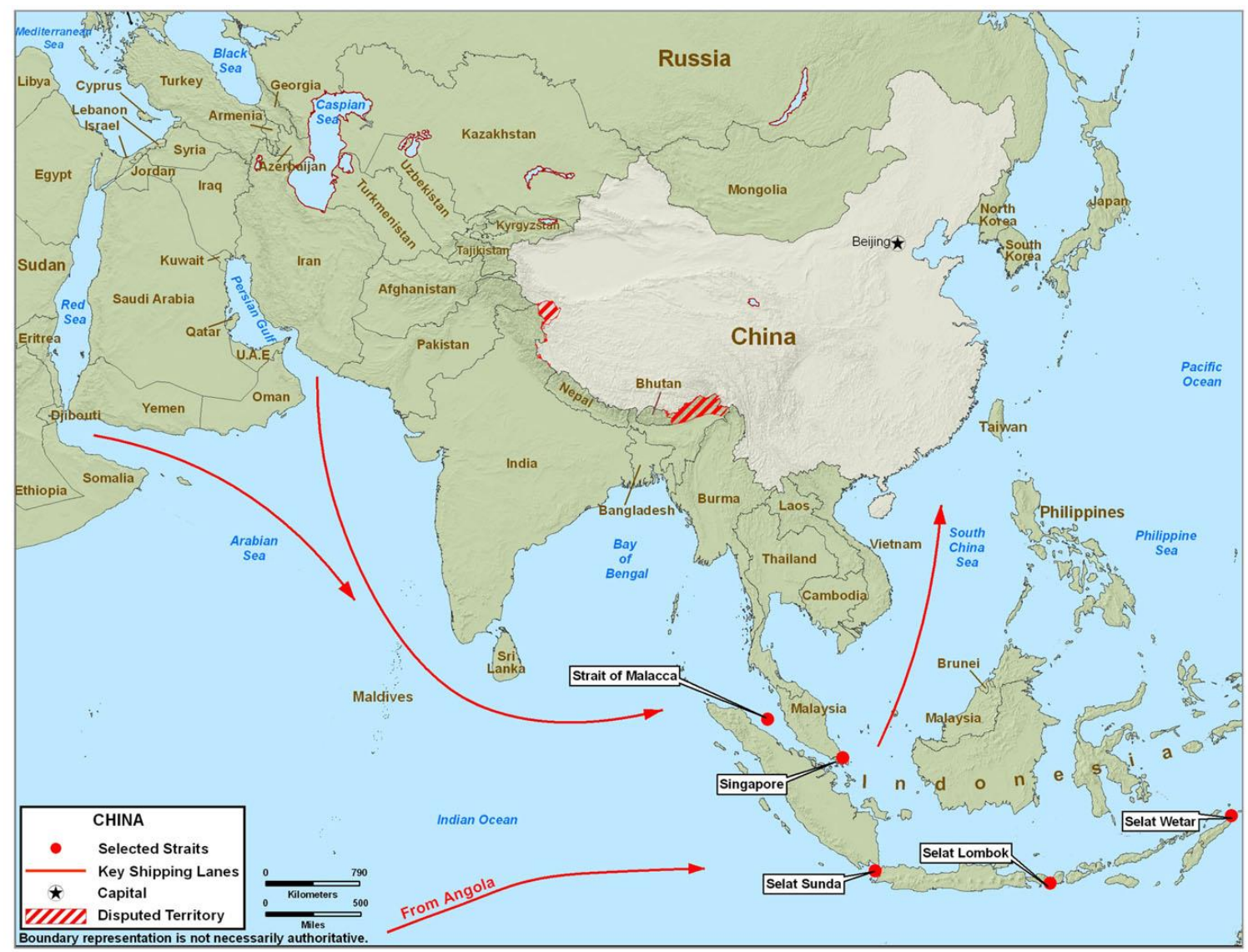

Figure 1. China's Critical Sea Lanes. Like many other industrialized East Asian countries, China is heavily dependent upon critical sea lanes for its energy imports. Over 80 percent of China's crude oil imports transit the Strait of Malacca.

Map 7: China's Sea Lanes of Communications. Source:

http://legacy.lib.utexas.edu/maps/middle_east_and_asia/china_critical_sea_lanes_2009.jpg

\section{Reshaping the Eurasian Energy Landscape}

China's entry into the Central Asian energy market began in 1997 after China's National Petroleum Corporation (CNPC), with active support from Premier Li Peng, won an international competitive bid for the operation of the Aktobe oil field in Kazakhstan. Winning this bid provided a 60\% share in AktobeMunaiGas, the fourth largest oil and gas company in Kazakhstan. ${ }^{618}$ This success was followed up on 2003 when CNPC bought an

${ }^{618}$ Daniel C. O'Neil, "Risky Business: The Political Economy of Chinese Investment in Kazakhstan," Journal of Eurasian Studies 5, 2014, p. 151 
additional 25\% stake in the field below the asking price. ${ }^{619}$ Since 2003, the CNPC has been able to buy significant stakes in major Kazakh oil and natural gas fields, making it a major player in the country's energy sector. ${ }^{620}$ This success led to a numerous accusations regarding corruption and bribery, ${ }^{621}$ however, it is clear that the Chinese government and the CNPC have been explicit in giving the Kazakh government a direct stake in Chinese investments. China has done this by linking loans to the Kazakh government with investment deals as well as providing Kazakhstan's national oil and gas company, KazMunaiGas, and its subsidiaries partial ownership of the joint ventures. ${ }^{622}$ This type of arrangement ensures a stable and amicable long-term relationship, something that the PRC needs in order to ensure its neighbor's cooperation as well as its domestic economic and energy security.

However, despite its success in obtaining access to Kazakh oil, the process of delivering oil from the fields, located in western Kazakhstan, to the Chinese border required the construction of new pipelines since no infrastructure existed connecting these two countries. Thus, Chinese and Kazakh government agreed to a pipeline constructed in two phases and three sections. Phase one would link two oil fields in western Kazakhstan,

\footnotetext{
${ }^{619}$ See: Alexander Cooley, Great Game, Local Rules: The New Great Power Contest in Central Asia (Oxford: Oxford University Press, 2012), p. 141; Daniel C. O’Neil, "Risky Business: The Political Economy of Chinese Investment in Kazakhstan,” Journal of Eurasian Studies 5, 2014, p. 151

${ }^{620}$ Daniel C. O’Neil, “Risky Business: The Political Economy of Chinese Investment in Kazakhstan,” Journal of Eurasian Studies 5, 2014, p. 151

${ }^{621}$ See: Alexander Cooley, Great Game, Local Rules: The New Great Power Contest in Central Asia (Oxford: Oxford University Press, 2012), p. 141; Daniel C. O’Neil, "Risky Business: The Political Economy of Chinese Investment in Kazakhstan,” Journal of Eurasian Studies 5, 2014, p. 151

${ }^{622}$ Daniel C. O’Neil, "Risky Business: The Political Economy of Chinese Investment in Kazakhstan,” Journal of Eurasian Studies 5, 2014, p. 151
} 
representing the first section of the pipeline. Phase two, would link the Atasu oil field in central Kazakhstan to the Chinese border landport of Alashankou, marking the second section of the pipeline. Lastly, the third section in phase two would connect the first and second stages, thus linking western and central fields to the Chinese market. ${ }^{623}$

The first section of what became the Kazakhstan-China Oil pipeline was completed in 2003. This section linked the Aktobe field to Caspian fields in Atyrau. In 2004 the China National Oil and Gas Exploration and Development Corporation CNODC, a subsidiary of the CNPC, and KazTransOil JSC, formed the Kazakhstan-China Oil Pipeline LLC in order to manage the construction and operation of the pipeline linking Kazakh oil fields to the Chinese border. ${ }^{624}$ This joint venture gave each founding member a 50/50 share of the LLC and paved the way for the completion of the next two sections of the pipeline. Section two was completed in 2005 and became commercially operational in 2006, marking a significant milestone for the two countries. ${ }^{625}$ For China, this milestone represented the first step in changing the energy landscape of the region, as well as its first step in attenuating its Malacca Dilemma. For Kazakhstan, this represented its first servicing of an external market outside of Russian control, thus providing it with greater economic diversification. The third and last section of the pipeline became operational in 2009, thus

\footnotetext{
623 "CNPC and KMZ to Double Crude Oil Pipeline from Kazakhstan to China," 2b1st Consulting, April 21, 2013, https://www.2b1stconsulting.com/cnpc-and-kmz-to-double-crude-oil-pipeline-from-kazakhstan-tochina/

624 “History,” Kazakhstan-China Pipeline LLC, 2016, http://www.kcp.kz/company/history

625 “Kazakhstan-China Crude Oil Pipeline," Hydrocarbons-Technology, http://www.hydrocarbonstechnology.com/projects/kazakhstan-china-crude-oil-pipeline/
} 
completing the project. This pipeline connects to the Alashankou-Dushanzi pipeline where crude oil is transported to the refinery in Dushanzi for further distribution. ${ }^{626}$

China's success in entering the Kazakh oil sector provided an opportunity to also secure natural gas. Until the turn of the century, natural gas had not been an important energy source in China. However, as part of its efforts to address issues of environmental degradation, particularly poor air quality due to the use of coal, the CCP embarked on a campaign to triple natural gas consumption by $2010 .{ }^{627}$ The West-East pipeline, proposed under the Great Western Development strategy at the tenth five-year plan, was intended to transport natural gas from Xinjiang's fields in the Tarim Basin to coastal economic hubs like Shanghai. Unfortunately, the deposits in Xinjiang, although substantial, were not expected to keep up with growing domestic demands for the projected 45 years that the pipeline was intended to operate. As a result, Kazakhstan's natural gas reserves were a natural choice due to its proximity as well as the established relationship.

In 2003, during a during a visit to Kazakhstan, Hu Jintao signed agreements with Kazakh President Nursultan Nazarbayev (1990-present) in order to expedite the appraisal of the feasibility of a Kazakhstan-China gas pipeline. ${ }^{628}$ This pipeline, however, was intended to be eventually extended to Uzbekistan, Turkmenistan, and ultimately, to Iran, thus finally giving China direct overland access to energy resources in the Persian Gulf. In

\footnotetext{
${ }^{626}$ Ibid.

${ }^{627}$ Leila Fernandez-Stembridge and Juan Antonio Fernandez, China's State Owned Enterprise Reforms: An Industrial CEO Approach (New York: Routledge, 2007), p. 117

628 “Firms Discuss Cross-border Gas Pipeline," China Daily, August 25, 2004, http://www.chinadaily.com.cn/english/doc/2004-08/25/content_368622.htm
} 
other words, the Kazakhstan-China gas pipeline was the intended to be the first step. This proposal, dubbed the "Pan Asian Global Energy Bridge" served as the prototype for what would eventually become the Central Asia-China gas pipeline. ${ }^{629}$ At the time of Hu's visit, Turkmenistan's Galkynysh gas field had not been confirmed. Therefore, Turkmenistan's inclusion into the proposed project was purely based on China's desire to tap Iran's energy sector through an overland route. However, in 2006, Gaffney, Cline \& Associates, a respected British energy auditing firm, announced that Turkmenistan's southern gas fields possessed the fourth largest reserves, making the country the energy crown jewel of Central Asia. Consequently, the CNPC doubled its efforts to enter Turkmenistan's market. ${ }^{630}$

On April 2, 2006, Turkmen President Saparmurat Niyazov (1990-2006), made a rare visit to China. This meeting led to an agreement in which China would buy 30 billion cubic meters of Turkmen gas for 30 years. Much like Nazarbayev, Niyazov was looking diversify his country's export partners and to set up new infrastructure to break the Russian monopoly on export routes for Turkmen gas. ${ }^{631}$ The following year, the CNPC became the first foreign company to gain access to Turkmenistan's vast onshore natural gas resources when it won a contract to develop the Samandepe field. ${ }^{632}$ That same year China finalized

${ }^{629}$ See: "Firms Discuss Cross-border Gas Pipeline," China Daily, August 25, 2004, http://www.chinadaily.com.cn/english/doc/2004-08/25/content_368622.htm; Alexandros Petersen and Frederik S. Starr, Eurasia's Shifting Geopolitical Tectonic Plates: Global Perspective, Local Theaters (Lanham: Lexington Books, 2017), p. 144

${ }^{630}$ Alexandros Petersen and Frederik S. Starr, Eurasia's Shifting Geopolitical Tectonic Plates: Global Perspective, Local Theaters (Lanham: Lexington Books, 2017), p. 144

${ }^{631}$ Daniel Kimmage, "Central Asia: Turkmenistan-China Pipeline Project Has Far-Reaching Implications," Radio Free Europe Radio Liberty, April 10, 2006, https://www.rferl.org/a/1067535.html

${ }^{632}$ Isabel Gorst, "Pipeline Brings Asian Gas to China," Financial Times, December 14, 2009, https://www.ft.com/content/38fc5d14-e8d1-11de-a756-00144feab49a 
a pipeline transit agreement with Uzbekistan and Kazakhstan, setting up the legal framework for beginning construction of the Central Asia-China gas pipeline. ${ }^{633}$ The project was planned as two parallel pipelines (Line A and B), that connected the Samandepe gas field to the Horgos landport. ${ }^{634}$ Construction of the Turkmen section of the pipeline began on August 30, 2007, while the Uzbek and Kazakh sections began on June 30, 2008 and July 9, 2008 respectively. Line A was completed by 2009 and by the following year, Line B was also operational, making this one of the fastest pipeline projects in the world. By 2011 Line A and B were operating at their combined 30 billion cubic meter capacity. ${ }^{635}$

The completion of these pipelines was an important event in Eurasian affairs, particularly the post-Soviet space. It signaled China's emergence as a major player in the energy sector. At Line A's inauguration ceremony in Kazakhstan, Nursultan Nazarbayev contended that "the startup of this pipeline reconstructs the ancient Silk Roads and symbolizes friendship and cooperation," referring to the regular usage of the historical Silk Road between Chinese leaders and their Central Asian counterparts. ${ }^{636}$ Turkmen President

\footnotetext{
${ }^{633}$ See: Bin Hu, "Oil and Gas Cooperation between China and Central Asia in an Environment of Political Resource Competition," Petroleum Science 11, 2014, p. 599; "Flow of Natural Gas from Central Asia," China National Petroleum Corporation, 2016, http://www.cnpc.com.cn/en/FlowofnaturalgasfromCentralAsia/FlowofnaturalgasfromCentralAsia2.shtml

634 “Central Asia-China Gas Pipeline, Turkmenistan to China,” Hydrocarbons-Technology, https://www.hydrocarbons-technology.com/projects/centralasiachinagasp/

635 "Flow of Natural Gas from Central Asia," China National Petroleum Corporation, 2016, http://www.cnpc.com.cn/en/FlowofnaturalgasfromCentralAsia/FlowofnaturalgasfromCentralAsia2.shtml

${ }^{636}$ Andrew E. Kreamer, "New Gas Pipeline from Central Asia Feeds China," The New York Times, December 14, 2009, http://www.nytimes.com/2009/12/15/world/asia/15pipeline.html
} 
Gurbanguly Berdymukhamedov (2006-present), stated that the Central Asia-China gas pipeline not only possessed commercial and economic value, but also political value. $\mathrm{He}$ added that "China, through its wise and long-sighted policy, has become one of the key guarantors of global security." ${ }^{937}$ Islam Karimov, his Uzbek counterpart, indicated that China's financial economic might was a key precondition for success," highlighting the transformational capacity of China's economic rise. ${ }^{638}$

It is evident that China was attempting to replicate its success in Kazakhstan in other Central Asian republics by following the same script: linking loans to investment deals and granting the target country partial ownership in the projects. In 2009, the Chinese Development Bank (CDB) lent Turkmenistan $\$ 3$ billion to develop its Galkynysh gas field, the second largest in the world, and allow CNPC to be a player in the field's development. ${ }^{639}$ The following year, China and Uzbekistan signed an agreement that would link Uzbekistan's natural gas infrastructure and provide China with an additional 10 billion cubic meters of natural gas. ${ }^{640}$ As a result of this agreement, on 2011, CNPC and Uzbekneftegas signed an agreement on the construction and operation of Line $\mathrm{C}$ of the Central Asia-China gas pipeline. This line became operational in 2014, bringing the total

\footnotetext{
${ }^{637}$ Isabel Gorst, "Pipeline Brings Asian Gas to China," Financial Times, December 14, 2009, https://www.ft.com/content/38fc5d14-e8d1-11de-a756-00144feab49a

${ }^{638}$ Ibid.

${ }^{639}$ See: "Galkynysh Gas Field,” Hydrocarbons-Technology, http://www.hydrocarbonstechnology.com/projects/galkynysh-gas-field-turkmenistan/; Huseyn Hasanov, "Will China get all Turkmen Gas?” Azernews, April 20, 2015, https://www.azernews.az/analysis/80656.html 640 "Central Asia-China Gas Pipeline, Turkmenistan to China," Hydrocarbons-Technology, https://www.hydrocarbons-technology.com/projects/centralasiachinagasp/
} 
capacity of the Central Asia-China gas pipeline to 55 billion cubic meters. ${ }^{641}$ According to the CNPC, "this equals to approximately $20 \%$ of China's annual natural gas consumption, and would substitute 73 million tons of standard coal, cutting carbon dioxide and sulfur dioxide emissions by 78 million tons and 1.21 million tons every year, respectively." ${ }^{\circ 42}$

The gains that China made in this sector in the span of a decade should not be underestimated. By 2014, the combined volume of oil and natural gas from Central Asia accounted for nearly $9 \%$ and $70 \%$ respectively of China's total imports. ${ }^{643}$ This signified a significant step in Hu Jintao's efforts to address China's Malacca Dilemma. However, just as obtaining access to oil and gas in Central Asia is not the same thing as being able to transport it to the Chinese border, being able to get it to said border is not the same thing as being able to distribute it within China. The previously mentioned West-East pipeline would serve this role. Although the tenth five-year plan envisioned the West-East pipeline to be an entirely domestic project where Xinjiang's Tarim Basin would supply the coastal region, it soon became apparent that the project needed to be integrated into the growing network of pipelines connecting Central Asia and China. This resulted in the West-East pipeline being reworked as four pipelines. The first pipeline began construction in 2002 and commenced commercial operations in $2004 .{ }^{644}$ This pipeline originated in Lunnan,

\footnotetext{
641 "Flow of Natural Gas from Central Asia," China National Petroleum Corporation, 2016, http://www.cnpc.com.cn/en/FlowofnaturalgasfromCentralAsia/FlowofnaturalgasfromCentralAsia2.shtml ${ }^{642}$ Ibid.

${ }^{643} \mathrm{Bin} \mathrm{Hu}$, "Oil and Gas Cooperation between China and Central Asia in an Environment of Political Resource Competition,” Petroleum Science 11, 2014, p. 602

644 “West-East Gas Pipeline Project Begins Commercial Operations," PetroChina Company Limited, December 30, 2004, http://www.petrochina.com.cn/enpetrochina/xwxx/201404/0163d5084c414ee89beb8bed60bb961c.shtml
} 
Xinjiang, at the Tarim Basin gas field, and "runs through Xinjiang, Gansu, Ningxia, Shaanxi, Shanxi, Henan, Anhui, Jiangsu, Zhejiang and Shanghai to its final station of Baihe Town of Shanghai in the east."

However, it was the second West-East Pipeline that finally began integrating Central Asian energy into the Chinese market. This pipeline began construction in 2008 and was completed by 2012. Originating at the Horgos landport, it connects with the Central Asia-China gas pipeline (Lines A and B) before making its way to its terminus in Hong Kong after traversing through Shanghai and Guangdong. This pipeline is considered the longest natural gas pipeline in the world. ${ }^{646}$ The third West-East Pipeline began construction in 2012 and was completed by $2014 .{ }^{647}$ It originates at the Horgos landport just like the second pipeline, however, it connects to Line $\mathrm{C}$ of the Central Asia-China gas pipeline before making its way to Fuzhou, Fujian. ${ }^{648}$ The fourth pipeline is still in in the planning stages, although there are indications that it would connect Tarim Basin and Sichuan deposits to the coastal provinces. ${ }^{649}$

${ }^{645}$ Ibid.

${ }^{646}$ See: "West-East Gas Pipeline Project," Hydrocarbons-Technology, https://www.hydrocarbonstechnology.com/projects/west-east/; "CNPC: Turkmenistan Gas Arrives at Guangdong," LNG World News, November 25, 2011, https://www.Ingworldnews.com/cnpc-turkmenistan-gas-arrives-at-guangdong/

647 “West-East Gas Pipeline Project,” Hydrocarbons-Technology, https://www.hydrocarbonstechnology.com/projects/west-east/

${ }^{648}$ See: "West-East Gas Pipeline III," Wood Mackenzie, November 1, 2017, https://www.woodmac.com/reports/upstream-oil-and-gas-west-east-gas-pipeline-iii-37188828; "West-East Gas Pipeline Project," Hydrocarbons-Technology, https://www.hydrocarbonstechnology.com/projects/west-east/

649 “West-East Gas Pipeline Project,” Hydrocarbons-Technology, https://www.hydrocarbonstechnology.com/projects/west-east/ 


\section{Beyond Post-Soviet Eurasia}

In addition to pursuing access to the Central Asian energy sector and successfully linking it to China's markets, Beijing sought to diversify its energy sources in Southwest Asia as well as capitalize on Pakistan's strategic location as a potential trade hub. In other words, China's region-building project was not only widening its area of cooperation, but also expanding its geographical boundaries beyond formal SCO members during this phase. The timing was ripe for these endeavors, particularly as the Bush Administration targeted Iran's nuclear program through sanctions. The numerous sanctions imposed by the US and the UN had rendered most of Iran's infrastructure in poor condition. Additionally, the nature of the sanctions meant that foreign firms could not invest significant amounts to renovate and exploit new and existing oil and gas fields in Iran. As a result, China found a strategic opening through which it could become a key player in Iran's energy sector. ${ }^{650}$ This was an important achievement for China since Iran possesses the fourth largest proven oil reserves and the second largest proven natural gas reserves. ${ }^{651}$ The partnership proved fruitful during this period. By the end of the decade Iran was supplying China with approximately $11 \%$ of its oil imports. ${ }^{652}$ Although no pipelines were planned to connect

\footnotetext{
${ }^{650}$ Manochehr Dorraj and Carrier L. Currier, "Lubricated by Oil: Iran-China Relations in a Changing World,” Middle East Policy Council 15(2), 2008, http://www.mepc.org/journal/middle-east-policyarchives/lubricated-oil-iran-china-relations-changing-world?print

651 “Iran," CIA World Factbook, February 28, 2018, https://www.cia.gov/library/publications/the-worldfactbook/geos/ir.html

652 Zahid Khan and Changgang Guo, "China's Energy Driven Initiatives with Iran: Implications for the United States,” Journal of Middle Eastern and Islamic Studies 11(4), 2017, p. 20
} 
Iranian energy resources to China's growing network in Central Asia during this period, these developments marked a shift for Tehran as Beijing became its biggest energy export customer and trade partner. ${ }^{653}$

At the same time, China's concerns about its Malacca Dilemma prompted interest in upgrading the Karakoram Highway, which runs from Xinjiang to Pakistan, in order to find the means to escape American maritime dominance in the Indo-Pacific. Although the road has existed for decades, its poor condition has mitigated its economic value. However, Hu Jintao's efforts to bypass the Malacca Strait highlighted the strategic value of the highway for China's economic security. Part of the effort to upgrade the highway also called for the upgrade of the port of Gwadar. This would provide China with a direct route from Xinjiang to the Indian Ocean, thus providing an overland route that circumvents the Malacca Straits and provides shorter maritime routes to Southwest Asia and East Africa. Furthermore, the port of Gwadar is not only able to serve as an overland commercial trade route, but also has the potential to act as an energy hub where tankers could offload their cargo into a future pipeline heading into China. ${ }^{654}$

The completion of these projects has had important political, economic, and social effects. The pipelines from China to Central Asia have begun to fundamentally reshape the Eurasian energy landscape. Traditionally dominated by Russia's investment and

\footnotetext{
${ }^{653}$ See: Manochehr Dorraj and Carrier L. Currier, "Lubricated by Oil: Iran-China Relations in a Changing World," Middle East Policy Council 15(2), 2008, http://www.mepc.org/journal/middle-east-policyarchives/lubricated-oil-iran-china-relations-changing-world?print; Zahid Khan and Changgang Guo, "China's Energy Driven Initiatives with Iran: Implications for the United states," Journal of Middle Eastern and Islamic Studies 11(4), 2017, p. 20

${ }^{654}$ Ian Storey, "China's “Malacca Dilemma,"” China Brief 6(8), 2006, https://jamestown.org/program/chinas-malacca-dilemma/
} 
infrastructure, China has presented itself to Central Asian producers as a legitimate and reliable partner. This has allowed Central Asian countries to find political and economic diversification and reduce their reliance on Russia. In fact, China's success in entering Central Asia's energy sector as well as expansion of trade, allowed it to surpass Russia as the region's primary trading partner. ${ }^{655}$ Furthermore, due to the significant costs of building an entirely new network of pipelines as well as the long-term nature of their contracts, it is clear that China plans to remain engaged in Eurasian affairs. The pipelines play a crucial strategic role in facilitating China's efforts to mitigate its Malacca Dilemma, something that is important to its economic and energy security and, consequently, its political and social stability. Furthermore, they serve domestic state-building goals since these pipelines not only lead to increased economic development, but also effectively integrate the western regions to the rest of the country. The gains made in Iran provide China with a pivotal partner in its future aims to reach the Persian Gulf through overland routes. Furthermore, it is clear that Iran is seen by the CCP leadership as not only the gateway to Southwest Asia, but especially during the third phase, as the gateway to the Caucasus and Europe.

Pakistan's strategic location is also important for China. Although it does not possess significant hydrocarbon resources, Pakistan is an important component of Chinese state-building efforts in Xinjiang in addition to providing a gateway into the Indian Ocean without needing to traverse the narrow straits that dot the South China Sea. Thus, Pakistan plays a crucial role in mitigating China’s Malacca Dilemma.

\footnotetext{
${ }^{655}$ See: Garret Mitchell, “China in Central Asia: The Beginning of the End for Russia?” SLOVO 26(1), 2014, p. 18; Alexander Cooley, "China's Changing Role in Central Asia and Implication for US Policy: From Trading Partner to Collective Goods Provider," U.S.-China Economic and Security Review Commission, March 18, 2015, p. 1-2, https://www.uscc.gov/sites/default/files/Cooley\%20Testimony_3.18.15.pdf
} 


\section{Conditions for Success}

China's success in making inroads into the Eurasian energy sector and infrastructure during this period is predicated on a number of important factors. The first is based on the flexibility of its finance offerings. China's Development Bank as well as its Eximbank have been at the forefront of providing loans to suitable partners that offer substantial benefits to the recipient. In Central Asia, Chinese banks, particularly the CDB and Eximbank, have provided a number of resource-backed loans that allow the recipient countries to pay for infrastructure and development with the profits made on commodities like oil and natural gas. ${ }^{656}$ These loans have paved the way for the CNPC and its subsidiaries to gain an important foothold in the region's energy sector. It is important to note that these resource-backed loans do not give China a lien on the oil or natural gas resources of the recipient country, rather, the lien is held on the revenue generated by the sale of these resources to China's SOEs. In essence, Chinese SOEs deposit payment for oil and natural gas deliveries directly into an account held by the borrowing entity at a bank like the CDB. The CDB then withdraws the interest, principal, and other fees it is owed from the account. ${ }^{657}$ This allows recipient countries the means to pay for major projects

\footnotetext{
${ }^{656}$ See: Erica Downs, "China’s Development Bank’s Oil Loans: Pursuing Policy - and Profit," China Economic Quarterly, 2011, p. 43-47; Andrew Bracken, Christina Hajj, Kristy Hartman, and Shivan Sivalingam, "China's Quest for Energy Security: Redefining and Driving Foreign Aid: An Analysis of China's Involvement in Central Asia and Africa," Policy Reports, Ford School University of Michigan, 2012, http://sites.fordschool.umich.edu/china-policy/files/2012/09/oil-and-aid-CHINA-FINALPAPER.pdf; Deborah Brautigam and Kevin P. Gallagher, "Bartering Globalization: China's Commoditybacked Finance in Africa and Latin America," Global Policy 5(3), 2014, p. 346-352

${ }^{657}$ Erica Downs, "China's Development Bank’s Oil Loans: Pursuing Policy - and Profit," China Economic Quarterly, 2011, p. 44
} 
without needing to tap into their hard currency reserves. Furthermore, China's willingness to provide partial ownership to host country enterprises allows it to establish stable longterm relationships. In addition to resource-backed loans, China has also included technology and equipment transfers to recipient countries in its loan terms. This is evident in cases like Iran, where international sanctions limit investment options. As a result, China has regularly traded equipment and technical expertise to Iran in exchange for access to its substantial resources. ${ }^{658}$

The financial crisis of 2008 also played a role in providing an opening for China's success. At a time when major financial institutions were unwilling to lend large amounts of money, especially to developing countries with little financial transparency or poor credit, China's aid and resource-backed loans filled the financial gap. This served the dual purpose of stabilizing the economy of its western neighbors, something that was crucial for stability in provinces like Xinjiang, but also allowed China's SOE's to make inroads into the local markets of aid and loan recipients. ${ }^{659}$ Beyond the economic and financial

\footnotetext{
${ }^{658}$ Zahid Khan and Changgang Guo, "China's Energy Driven Initiatives with Iran: Implications for the United states," Journal of Middle Eastern and Islamic Studies 11(4), 2017, p. 20

${ }^{659}$ See: Erica Downs, “China's Development Bank’s Oil Loans: Pursuing Policy - and Profit," China Economic Quarterly, 2011, p. 43-47; Andrew Bracken, Christina Hajj, Kristy Hartman, and Shivan Sivalingam, "China's Quest for Energy Security: Redefining and Driving Foreign Aid: An Analysis of China's Involvement in Central Asia and Africa," Policy Reports, Ford School University of Michigan, 2012, http://sites.fordschool.umich.edu/china-policy/files/2012/09/oil-and-aid-CHINA-FINALPAPER.pdf; Otaviano Canuto and Havard Halland, "Resource-Backed Investment Finance in Lead Developed Countries," The World Bank, September 23, 2013, http://blogs.worldbank.org/growth/resourcebacked-investment-finance-least-developed-countries; Matthew Sussex, "From Retrenchment to Revanchism..and Back Again? Russian Grand Strategy in the Eurasian 'Heartland,"' in Russia, Eurasia and the New Geopolitics of Energy: Confrontation and Consolidation, eds. Matthew Sussex and Roger E. Kanet (New York: Palgrave MacMillan, 2015), p. 36; Alexander Cooley, "China's Changing Role in Central Asia and Implication for US Policy: From Trading Partner to Collective Goods Provider," U.S.China Economic and Security Review Commission, March 18, 2015, p. 2-3, https://www.uscc.gov/sites/default/files/Cooley\%20Testimony_3.18.15.pdf
} 
component to China's success in deepening its engagement in Eurasian affairs, there was an important geopolitical component. In the post-Soviet space there were rising concerns about Russia's interference in the internal affairs of CIS members. The war with Georgia in 2008 only heightened concerns that Russia's resurgence would lead to similar events in Central Asia, particularly Kazakhstan which shared a long border with Russia and possessed the largest Russian diaspora in the region. ${ }^{660}$ Furthermore, political and economic rows between Russia and its CIS members led to various incidents regarding the flow of natural gas in 2006, thus threatening their economic and energy security. ${ }^{661}$ Turkmenistan in particular has a number of problems with Russian dominance of Eurasian energy transit. Ashgabat has regularly complained about the low payments of Gazprom, Russia's energy giant, for Turkmen gas as well as Gazprom's neglect of the pipeline it operates in Turkmenistan. This pipeline exploded in 2009, severely cutting Turkmenistan's ability to export natural gas to European markets. ${ }^{662}$

These events intensified two key concerns regarding Russia's historically dominant position in Central Asia. The first is that Russian leadership has shown a willingness to pressure CIS members politically, going as far as intervening militarily as it did in Georgia

\footnotetext{
${ }^{660}$ Charles E. Ziegler, "Sovereignty, Security and Intervention in Central Asia," in Russia, Eurasia and the New Geopolitics of Energy: Confrontation and Consolidation, eds. Matthew Sussex and Roger E. Kanet (New York: Palgrave MacMillan, 2015), p. 91-111

661 “Turkmen in Gas Warning to Russia,” BBC News, June 21, 2006, http://news.bbc.co.uk/2/hi/business/5101588.stm

${ }^{662}$ See: "Turkmen in Gas Warning to Russia," BBC News, June 21, 2006, http://news.bbc.co.uk/2/hi/business/5101588.stm; Bruce Pannier, "Pipeline Explosion Raises Tension Between Turkmenistan, Russia," Radio Free Europe Radio Free Liberty, April 14, 2009, https://www.rferl.org/a/Pipeline_Explosion_Stokes_Tensions_Between_Turkmenistan_Russia/1608633.ht $\mathrm{ml}$
} 
in 2008. The second is that Moscow has also made use of its overwhelming leverage as operator of most of Eurasia's energy transit in order to politically and economically pressure its neighbors. These actions were viewed as a threat to Central Asian sovereignty and autonomy. As a result, most of the Central Asian republics pursued a variation of multivector diplomacy in order to protect their sovereignty and autonomy during this period. ${ }^{663}$ China, being geographically proximate, possessing vast economic resources, and being normatively acceptable, emerged as a natural partner for these republics. Consequently, these republics have played a key role in facilitating China's growing engagement in Eurasian affairs.

In the case of Iran and Pakistan, the dynamics are different although there are important overlaps with the Central Asian experience. Rather than fear of Russian dominance, it is American dominance of the Persian Gulf that has brought about numerous problems. Furthermore, American-led Western sanctions politically and economically isolated Iran, leaving it with few international backers. Although China has followed America's lead in the sanctions regime that was established against Iran during the first decade of the $21^{\text {st }}$ century, it has also used the threat of its veto power in the Security Council to water down the imposed sanctions or outright resisted imposing further sanctions. ${ }^{664}$ This has made China one of Iran's main backers at the UN Security Council.

\footnotetext{
${ }^{663}$ See: Reuel R. Hanks, “'Multi-Vector Politics' and Kazakhstan's Emerging Role as Geostrategic Player in Central Asia," Journal of Balkan and Near Eastern Studies 11(3), 2009, p. 257-267; Alexander Pikalov, "Uzbekistan Between the Great Powers: A Balancing Act or a Multi-Vectoral Approach," Central Asian Survey 33(3), 2014, p. 297-311; Karen Smith Stegen, "Outcomes and Strategies in the 'New Great Game': China and the Caspian States Emerge as Winners," Journal of Eurasian Studies 6(2), 2015, p. 91-106

${ }^{664}$ David Santoro, "European and P5 Responses to Iran's Nuclear Program," in International Cooperation on WMD Nonproliferation, ed. Jeffrey Knopf (Athens: University of Georgia Press, 2016), p. 280-281
} 
Furthermore, as indicated above, China has found ways to invest in the development and renovation of Iran's energy sector despite the existing sanctions. As a result, China has emerged as Iran's main political and economic partner.

Pakistan's case also differs from the Central Asian and Iranian experience. Having been one of the first countries to establish diplomatic relations with the PRC, Pakistan and China enjoy what both sides have referred to as an all-weather friendship. Although Pakistan had to manage its close relationship with the US, it emerged as an early supporter of the PRC's entry into the UN in 1961, leading to an improvement of bilateral ties. By 1963 the two countries settled their disputed border, an important development for both sides in the context of their shared rivalry with India, as well as for China's efforts to more effectively control Xinjiang's southern border. ${ }^{665}$ Since this event, the two countries have a shared a close strategic partnership. Therefore, China's success in pursuing greater security and economic ties with Pakistan in order to more effectively develop its western provinces is predicated on a relationship that has already paid dividends for both sides for a number of decades. Furthermore, although Pakistan's relationship with the US remained a pillar of the country's political and economic stability, the George W. Bush administration's efforts to develop close ties with India, led to Pakistan's closer relations with China during this period.

665 "China-Pakistan Relations," Ministry of Foreign Affairs of the People's Republic of China, November 14, 2006, fmprc.gov.cn 


\section{Developing Ideational Power}

As indicated throughout the chapter, the PRC has sought to promote a number of norms through its region-building project that facilitate its state-building efforts. This has required the promotion of international norms that focus on inter-state relations. All of these norms, however, are underpinned by a domestic imperative. The development of the Five Principles of Peaceful Coexistence, and their incorporation into numerous agreements signed between China and its neighbors, provides China the vehicle to advocate for policies of non-interference in a country's internal affairs, cooperation for mutual benefit, peaceful coexistence, non-aggression, and more importantly, the respect for a country's territorial integrity and sovereignty. These principles can be traced to the historical experience of the hundred years of national humiliation. Nevertheless, they possess contemporary utility. It is through these principles that the CCP leadership can legitimize domestic policies that are internationally criticized. In other words, they provide normative cover from Westernliberal norms, something that resonates with the global south. Furthermore, the enshrinement of these principles in various SCO documents, for example, increases China's appeal as a normatively acceptable partner for its members. In fact, China's ability to demonstrate its adherence to these principles during border negotiations with post-Soviet states played a key role in the normalization of relations as well as its emergence as a key player in Eurasian affairs.

In addition to the five principles, the PRC has also demonstrated its normative capacity by externalizing its securitization of the three evils, something that has resonated with its western neighbors that possess their own restive populations. More importantly, however, by indicating that the solution to the three evils is development, China can present 
itself as a suitable aid and investment partner. Thus, the externalization of its understanding of the security-development nexus is perhaps China's greatest success during this period. This is further complemented by Beijing's flexible approach to aid and investment. Furthermore, China's support for the respect of different development systems demonstrates its continued adherence to the five principles. As a result, this makes China a normatively acceptable partner since it does not push for liberal political and economic reforms as a precondition to aid and investment. More importantly, however, by advocating for the diversity of economic development systems, China is not only presenting an explicit critique of the dominant liberal-normative order exemplified by the Washington Consensus, it is also increasing the appeal of its development model through its economic success. In essence, Eurasia has provided a suitable environment for China to craft and develop its ideational power. Thus, although China refers to these norms regularly in its relations with every state with which it has established relations, Eurasia, especially post-Soviet Central Asia, has served as the testbed for China's ideational power development.

China's effort to develop its ideational power go beyond establishing inter-state norms. Beginning in 2004, through its Confucius Institutes, China has sought to increase its cultural appeal by attempting to generate Sinophiles across the world; and once again, Eurasia is a prime location to pursue this effort. The very first Confucius Institute was set up in Tashkent, Uzbekistan, in 2004 ${ }^{666}$ By the end of 2009, every Central Asian republic, barring Turkmenistan, as well as Russia, Afghanistan, Iran, and Pakistan, had a Confucius

\footnotetext{
${ }^{666}$ Ren Qi, "China Daily Reporter Visits Confucius Institutes on the Belt and Road," Hanban News, December 26, 2016, http://english.hanban.org/article/2016-12/21/content_668899.htm
} 
Institute. ${ }^{667}$ These institutes aim to enhance foreigner's "understanding of Chinese language and culture, developing friendships between Chinese and foreign peoples, promoting the diversity of world culture and making contributions to a harmonious world." ${ }^{668}$ Additionally, they provide scholarships to students who are interested in improving their Mandarin skills by studying in China. It is hoped that students participating in the Confucius Institute's many programs and community outreach activities will become goodwill ambassadors for China in the same manner that the United States' many overseas scholarship and educational programs are. There is power in having an internationally appealing culture. During his speech at the $17^{\text {th }}$ National Congress of the Chinese Communist Party in 2007, Hu Jintao stated that culture had become an important source of national cohesion and creativity as well as a "factor of growing significance in the competition in overall national strength." ${ }^{\circ 69}$

Although it is unclear whether these institutes have made Chinese culture internationally appealing, it is evident that they have provided a strong platform for greater numbers of Mandarin language speakers in Eurasia. However, the appeal of the language is correlated with China's economic success and its growing presence in the region. Young people, as well as adults, appear to be attending Mandarin language courses at the Confucius Institutes in order to improve their economic conditions. Some of these students

\footnotetext{
667 “About Confucius Institute/Classroom,” Hanban, http://english.hanban.org/node_10971.htm

${ }^{668}$ Zhili Chen, "A Successful Example of International Chinese Language Promotion and Chinese-Foreign Cultural Exchanges-to the $10^{\text {th }}$ Anniversary of the Confucius Institutes," Hanban News, February 5, 2015, http://english.hanban.org/article/2015-02/05/content_573650.htm

669 "Hu Jintao's Report at $17^{\text {th }}$ Party Congress," China Daily, October 25, 2007, http://www.chinadaily.com.cn/china/2007-10/25/content_6225092_7.htm
} 
obtain scholarships to attend school in China through the institutes, making them prized commodities in their home countries as their governments aim to attract further Chinese investment. As more Chinese firms enter the local economy, many of these students have been able to obtain jobs as translators and interlocutors to Chinese investors and customers. ${ }^{670}$ In other words, the institutes are improving the human capital of their host countries in Eurasia, thus facilitating China's entry into their local markets.

China's success in increasing Sinophiles in Eurasia during this period occurred simultaneously with the decline of Russophiles in the post-Soviet space. Due to poor political and economic conditions after the collapse of the USSR, many ethnic Russians began to leave the region for the Russian Federation. ${ }^{671}$ There have also been efforts by Central Asian governments to promote the native language over Russian, thus reducing the language's former status as the lingua franca in the region. ${ }^{672}$ Furthermore, China's emergence as an economic power and primary investor in the region increased the appeal

\footnotetext{
${ }^{670}$ See: Xing Wang, "Institute Brings Knowledge of Chinese Culture to Kazakhs," China Daily USA, June 15, 2011, http://usa.chinadaily.com.cn/epaper/2011-06/15/content_12701171.htm; Yao Chen, "Kyrgyz Confucius Institutes-Cultural Envoys Between Kyrgyzstan, China,” 24, October 20, 2014, https://24.kg/archive/en/bigtiraj/172754-news24.html/; Ren Qi, "China Daily Reporter Visits Confucius Institutes on the Belt and Road," Hanban News, December 26, 2016, http://english.hanban.org/article/201612/21/content_668899.htm

${ }^{671}$ See: Sebastien Peyrouse, "The Russian Minority in Central Asia: Migration, Politics, and Language," Kennan Institute Occasional Paper \# 297, 2008, https://www.wilsoncenter.org/sites/default/files/OP297.pdf; Victoria Panfilova, "Russian Exodus Continues from Central Asia," Russia \& India Report, August 25, 2014, http://in.rbth.com/world/2014/08/25/russian_exodus_continues_from_central_asia_37791; Paul Goble, "Ethnic Russians Leaving Central Asia and Them, Putin's Hopes for Influence," Eurasia Daily Monitor 13(22), 2016, https://jamestown.org/program/ethnic-russians-leaving-central-asia-and-with-them-putinshopes-for-influence/

${ }^{672}$ See: Carolyn Kissane, "Education in Central Asia: Traditional Challenges and Impacts," in The Politics of Transition in Central Asia and the Caucasus: Enduring Legacies and Emerging Challenges, eds. Amanda E. Wooden and Christopher H. Stefes (New York: Routledge, 2009), p. 226-248; Jacob M. Landau and Barbara Kellner-Heinkele, Language Politics in Contemporary Central Asia: National and Ethnic Identity and the Soviet Legacy (London: I.B. Tauris, 2012)
} 
of learning Mandarin and attending school in China, especially among the new generation. Consequently, while the decrease of Russophiles in the post-Soviet space is not directly caused by China's emergence as a key player in the region, these conditions have facilitated the growth of Sinophiles.

\section{$\underline{\text { Conclusion }}$}

This phase saw the expansion of China's domestic state-building efforts, which entailed expansion of region-building efforts. The security-development nexus logic continued to be the foundation to these projects, however, as CCP officials expanded the scope of what was necessary to secure and develop the country, so did the sectors and countries that were part of Beijing's Eurasian region-building project (see map 8). The focus on consolidating gains made in the previous phase, coupled with the emergence of the global war on terror and the concern for its energy security, particularly its effect on the economy and social stability, were crucial during this phase. As a result, China pursued the institutionalization of the Shanghai Five forum as well as the norms that were the core of China's foreign policy. This institutionalization increased the cooperative sectors under the SCO in addition to expanding the geographical boundaries of the project through the addition of Uzbekistan. Furthermore, as concerns of the Malacca Dilemma grew, Turkmenistan, Iran and Pakistan became incorporated into China's region-building project as Beijing sought to diversify its energy source and bypass the US-dominated maritime commons, thus expanding the geographical boundaries yet again. 


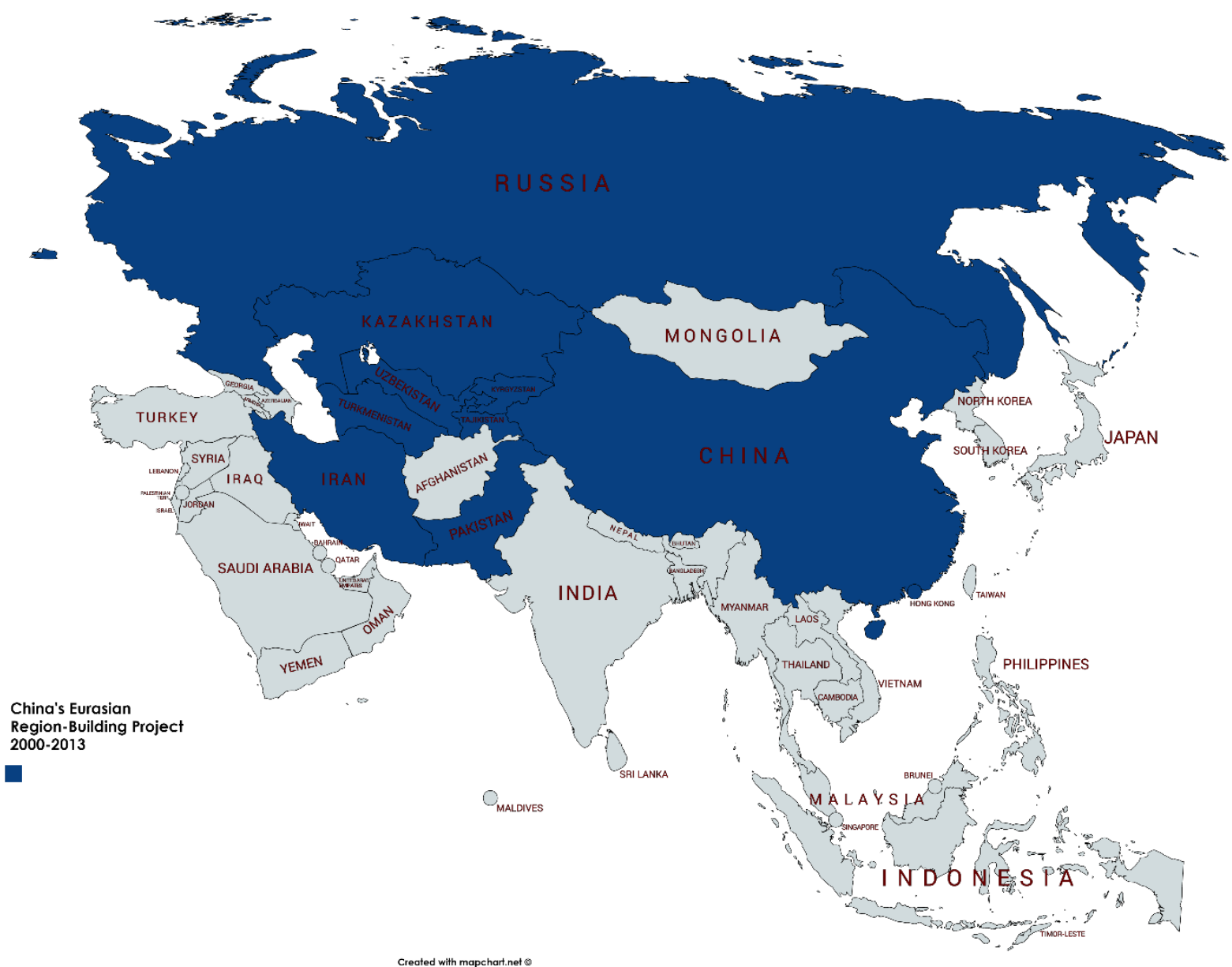

Map 8: China's Eurasian Region-Building Project 2000-2013. Generated from https://mapchart.net/asia.html 


\section{Chapter 4: 2013-Present: National Rejuvenation and Regional Transformation}

On November 15, 2012, Xi Jinping was selected as the new General Secretary of the Chinese Communist Party, thus taking the helm of the People's Republic of China at a crucial time in its historical trajectory. His inaugural speech, though short, provided a small insight into his vision for China. During the speech, Xi highlighted the important role that the CCP had played in transforming China from an old and backward country into a powerful one. Now, Xi contended, the stage was set for the CCP to lead "people of all ethnic groups in China in taking over the relay baton passed on to us by history, and in making continued efforts to achieve the great renewal of the Chinese nation." ${ }^{673} \mathrm{He}$ supplemented this speech during his second official appearance as General Secretary. On November 30, 2012, Xi Jinping visited an art exhibit at the National Museum of China titled "The Road to Renewal." The exhibition provided a fitting stage for Xi to present his vision: the "Chinese Dream." The Chinese dream, he said, was the "rejuvenation of the Chinese nation." ${ }^{674}$ At this visit, Xi Jinping connected the two centenary goals set out by the $18^{\text {th }}$ National Congress of the CCP, where he was elected, to the Chinese dream. The two centenary goals refer to establishing a "moderately prosperous society" by 2020 , the $100^{\text {th }}$ anniversary of the founding of the CCP, and establishing a "modern socialist country that is prosperous, strong, democratic, culturally advanced and harmonious," by 2049, the

\footnotetext{
673 "Transcript: Xi Jinping's Speech at the Unveiling of the New Chinese Leadership," South China Morning Post, November 15, 2012, http://www.scmp.com/news/18th-partycongress/article/1083153/transcript-xi-jinpings-speech-unveiling-new-chinese

${ }^{674}$ Gang Wu and Shuang Yan, "Xi Jinping Pledges 'Great Renewal of Chinese Nation,'” Global Times, November 30, 2012, http://www.globaltimes.cn/content/747443.shtml
} 
$100^{\text {th }}$ anniversary of the founding of the PRC. ${ }^{675}$ Xi Jinping also reflected that China's 170 s years struggle since the Opium War proved that a weak nation would be the target of bullying, adding that only development could make China strong. In other words, the Chinese dream of national rejuvenation corresponded with the continued economic development of the PRC and its emergence as a strong and modern developed country, thus demonstrating the continued reliance on security-development nexus logic and the Party's role in this dynamic. The Chinese dream of national rejuvenation, achieved through accomplishing the two centenary goals, is a state-building initiative.

Xi Jinping's goal of making the achievement of the Chinese dream of national rejuvenation a hallmark of his administration, though apparently similar to the expressed goals of previous leaders, revealed a more proactive approach to domestic state-building and region-building efforts. Thus, Deng Xiaoping's maxim: “observe calmly, secure our position, cope with affairs calmly, hide our capacities and bide our time, be good at maintaining a low profile, and never claim leadership," ${ }^{676}$ having established the foundations for a stronger China, was giving way to Xi Jinping's Chinese dream of national rejuvenation. Xi spared no time to make his grand bid for the Chinese dream. On September 3, 2013, he kicked off a tour of Central Asian countries on his way to the SCO Bishkek summit that was slated for the $13^{\text {th }}$. Chinese media and analysts speculated that this trip

\footnotetext{
${ }^{675}$ See: Gang Wu and Shuang Yan, "Xi Jinping Pledges 'Great Renewal of Chinese Nation,"” Global Times, November 30, 2012, http://www.globaltimes.cn/content/747443.shtml; "Full Text of Hu Jintao's Report at the $18^{\text {th }}$ Congress," Embassy of the People's Republic of China in the United States of America, November 27, 2011, http://www.china-

embassy.org/eng/zt/18th_CPC_National_Congress_Eng/t992917.htm

${ }^{676}$ Youji Huang, "Context, not History, Matter for Deng's Famous Phrase," Global Times, June 15, 2011, http://www.globaltimes.cn/content/661734.shtml
} 
would have regional and international significance and would contribute greatly to realizing the Chinese dream. As Xiudong Jia, a senior research fellow at the China Institute of International Studies, indicated, China had only just established relations with Central Asian countries a little over 20 years at this point. Jia described the growing relationship between China and its Central Asian partners as evolving quickly, stating that "the first 10 years was a decade of beginning and warming-up; the second 10 years was a decade of rapid progress, as for the coming 10 years, it will be a golden decade of all-dimensional and high-level development." ${ }^{\prime 677}$ Jia's comments were right on the mark, as Xi Jinping's tour would set in motion the most ambitious Chinese policy of the $21^{\text {st }}$ century.

Xi's first stop on his Central Asian tour was Ashgabat, Turkmenistan. There he met with his Turkmen counterpart, Berdymukhamedov, and expressed the importance of Turkmenistan to China's energy security as well as the historical and cultural links that bind the two nations. Xi Jinping also made reference to the five principles, the three evils, and the importance of development to the security and stability of the state as the basis for their relationship. On that note, $\mathrm{Xi}$ proposed increasing economic ties in non-resource sectors, marking an important development for this phase of China's foreign policy in the region. This meeting concluded with the mutual agreement to elevate diplomatic ties to strategic partnership status and to continue expanding energy ties. As a result, China secured an agreement to be supplied with 65 billion cubic meters of natural gas annually

\footnotetext{
677 “Xi’s Trip to Promote Win-Win Cooperation,” CCTV English, August 28, 2013, http://english.cntv.cn/20130828/105024.shtml
} 
through the three lines of the Central Asia-China gas pipeline, in addition to the proposed Line D which will be discussed further below. ${ }^{678}$

However, it was Xi's second stop that would prove more significant. On September 7, 2013, Xi gave a speech titled "Promote People-to-People Friendship and Create a Better Future" Nazarbayev University in Astana, Kazakhstan. In this speech, Xi spoke about the 2,000-year plus history of exchanges between China and the peoples of modern day Kazakhstan, a product of the linkages created by the Silk Road. He indicated that this historical relationship proved that countries of different races, beliefs, and cultural backgrounds could live in peace and prosperity as long as they "persist in unity and mutual trust, equality and mutual benefit, mutual tolerance and learning from each other, as well as cooperation and win-win outcomes. ${ }^{, 679}$ In order to accomplish these things, Xi again referred to the five principles, promising that China would not interfere with the domestic and foreign affairs of Central Asian countries, and called for continued support against the three evils in order to ensure state sovereignty, territorial integrity, as well as security and stability. Furthermore, in order to strengthen cooperation and continuing to develop a relationship based on mutual benefit and win-win opportunities, Xi called on his Central Asian counterparts to take advantage of their political relations, geography, and economic

\footnotetext{
${ }^{678}$ See: Teddy Ng, "Xi Jinping Secures Greater Security and Energy Ties with Turkmenistan,” South China Morning Post, September 3, 2013, http://www.scmp.com/news/china/article/1302636/xi-arrivesturkmenistan-first-leg-central-asia-tour; "Xi Jinping Holds Talks with President Gurbanguly Berdymukhamedov of Turkmenistan, Two Heads of State Announce Establishment of China-Turkmenistan Strategic Partnership," Embassy of the People's Republic of China in the United States of America, September 4, 2013, http://www.china-

embassy.org/eng/zt/xijinpingfangwenzhongyawuguobingchuxiG20fenghui/t1073474.htm

679 "President Xi Jinping Delivers Important Speech and Proposes to Build a Silk Road Economic Belt with Central Asian Countries," Ministry of Foreign Affairs of the People's Republic of China, September 7 , 2013, http://www.fmprc.gov.cn/mfa_eng/topics_665678/xjpfwzysiesgjtfhshzzfh_665686/t1076334.shtml
} 
complementarity, and turn them into practical cooperation and sustainable growth. This he argued, would result in a community of shared interests. ${ }^{680}$

It was here that $\mathrm{Xi}$ Jinping presented the path towards a community of shared interests. Xi proposed that in "order to make the economic ties closer, mutual cooperation deeper and space of development broader between the Eurasian countries, we can innovate the mode of cooperation and jointly build the "Silk Road Economic Belt" step by step to gradually form overall regional cooperation." 681 Thus, the Silk Road Economic Belt, or the Belt Road Initiative as it was later called, represented Xi Jinping's expansion of China's Eurasian region-building project. In an effort to provide a preliminary blueprint for establishing this Silk Road Economic Belt, Xi proposed five guidelines. The first was to strengthen policy communication. While he continued to advocate for the respect of each country's own path to development, Xi proposed that each country should communicate with each other regarding their respective development strategies and assess how they might complement each other for regional cooperation. The second guideline was to improve road connectivity. The vision was to create a transportation channel from the Pacific Ocean to the Baltic Sea and to gradually form a transportation network that would connect East Asia, Southwest Asia, and South Asia. In other words, Xi was proposing the re-connection of the Eurasian sub-regions through integrative infrastructure for the purpose of common development. The third guideline was to promote trade facilitation. Here again the idea was for countries to coordinate how they might be able to gradually remove trade barriers based on a reciprocity. The fourth guideline was to enhance monetary circulation

\footnotetext{
${ }^{680}$ Ibid.

${ }^{681}$ Ibid.
} 
by settling their local currencies in order to conduct trade in local currency and fend off financial risks. Lastly, Xi proposed that people-to-people exchanges should be strengthened in order to increase friendship and better understanding. ${ }^{682}$

Xi's proposal was ambitious, however, it did not deviate far from previous Chinese initiatives of the 1990s and the first decade of the $21^{\text {st }}$ century in spirit and rhetoric. However, in practical terms, its scope was fundamentally wider, particularly as Xi was pursuing the physical integration of the Eurasian sub-regions through infrastructure beyond the non-resource sector. Thus, while China would continue to expand its footprint in the region's energy sector, this phase would mark a shift towards infrastructure that more effectively connected China to Eurasian markets through overland routes. For Xi Jinping, the Silk Road Economic Belt, in conjunction with the $21^{\text {st }}$ Century Maritime Silk Road announced a few months later during his visit to Jakarta, Indonesia, was essential to the Chinese dream and national rejuvenation, since it was through this initiative that China could achieve its next stage of development in the $21^{\text {st }}$ century. Thus, the state-building and region-building projects were more explicitly linked. However, being able to propose this initiative required some political and economic foundation to have already been in place. Therefore, just like the Xinjiang's double-opening strategy provided the foundation for the CCP to pursue the Great Western Development strategy, the Great Western Development strategy provided the launchpad for the Belt Road Initiative.

${ }^{682}$ Ibid. 


\section{The Great Western Development and the Silk Road Economic Belt}

On the eve of Xi Jinping's transformational speech at Nazarbayev University, he was certainly cognizant of the successes and failures of the Great Western Development strategy and China's Eurasian region-building project. As indicated in the previous chapter, the GWD strategy was more than an economic initiative, it also possessed crucial political and social components. Therefore, its success and shortcomings need to be measured against the stated objectives of the strategy along these three dimensions. The GWD strategy's main successes have been political and social. As part of a state-building effort that sought to consolidate state integration processes in minority areas like Xinjiang, the GWD strategy had measurable success. ${ }^{683}$

State capacity, and consequently, state reach, increased in the western regions through the development of infrastructure during the first decade of the $21^{\text {st }}$ century. For example, by 2006 , new roads built in the western provinces had reached nearly 220,000 kilometers including roughly 6,900 kilometers of highways. ${ }^{684}$ This had the added value of increasing mobility and facilitate economic development. At the same time, they allowed central authorities to access the western provinces more effectively and respond to social unrest more quickly. Thus, infrastructure played a key role in state-building efforts. Furthermore, China's successful externalization of the securitization three evils through

\footnotetext{
${ }^{683}$ See: Nicolas Becquelin, "Staged Development in Xinjiang," The China Quarterly 178, 2004, p. 358378; David S.G. Goodman, "The Campaign to "Open up the West": National, Provincial-Level and Local Perspectives," The China Quarterly 178, p. 317-334; Victor Shih, "Development, the Second Time Around: The Political Logic of Developing Western China," Journal of East Asian Studies 4(3), 2004, p. 427-451; Jihyeon Jeong, "Ethnic Minorities in China's Western Development Plan," Journal of International and Area Studies 22(1), 2015, p. 1-18

${ }^{684}$ John A. Donaldson, "Regional Development Policy and Regional Inequality," in Handbook of the Politics of China, ed. David S.G. Goodman (Cheltenham: Edward Elgar Publishing, 2015), p. 198
} 
the SCO platform, as well as the co-optation of the American global war on terror, facilitated the CCP's efforts to exercise domestic control of its Muslim minorities in addition to being able to minimize their movement and activities abroad. In other words, this successful externalization was an important international component to the CCP's domestic state-building efforts in its western frontier.

Economically, the GWD strategy's success was decidedly mixed. On one hand, As Premier Li Keqiang (2013-present) indicated at the meeting for the thirteenth five-year plan (2016-2020), through the GWD strategy the Chinese government had invested roughly \$914 billion from 2000-2016 in 300 major projects focused on transportation infrastructure and the energy sector. As a result of this investment, the western provinces' share of national GDP had increased to $21.1 \%$ from $17 \%$ in $2000 .{ }^{685}$ The western provinces also experienced fast growth during the $2000-2010$ period, posting an average of $13.5 \%$ annual growth each year and exceeding the growth of the central and northeastern provinces. ${ }^{686}$ This would indicate measurable economic success for the GWD strategy, especially at a macro level. On the other hand, however, the strategy had failed to address the widening development gap between the coastal provinces and the west. By 2016 Shanghai, which is counted as a province by virtue of being a directly-controlled municipality, was five times wealthier than Gansu province, indicating a very high level of inequality since it surpasses the gap that exists between states in notoriously unequal

\footnotetext{
685 "New Five-Year Plan Brings Hope to China's West," State Council of the People's Republic of China, December 27, 2016, http://english.gov.cn/premier/news/2016/12/27/content_281475526349906.htm

${ }^{686}$ John A. Donaldson, "Regional Development Policy and Regional Inequality," in Handbook of the Politics of China, ed. David S.G. Goodman (Cheltenham: Edward Elgar Publishing, 2015), p. 198
} 
Brazil. ${ }^{687}$ This is a problem that Xi Jinping has explicitly recognized as he attempts to realize the goal of achieving a moderately prosperous society by 2020. During a visit to villages in Ningxia province to inspect poverty alleviation work, Xi stated that "no one should be left behind," adding that there were still roughly 50 million Chinese struggling with poverty and that his top concern was to lift them out of this condition by $2020 .{ }^{688}$

Adding to the problems of a widening development gap, the GWD strategy was unable to fundamentally alter the FDI gap. Although FDI did grow in the western provinces throughout the first decade of the strategy, the rates were too low to close this gap. ${ }^{689}$ Furthermore, the amount of FDI that the western provinces received was not substantial enough to fundamentally address the core problems that plagued the western region: (1) their economies continue to be dominated by SOEs; (2) and they remain heavily dependent on subsidies and fiscal transfers from the center. ${ }^{690}$ In fact, both of these problems compound each other. The focus on large-scale projects, aimed at creating suitable conditions for foreign companies to invest, requires massive capital investment from the center. Consequently, the investment will be directed to a state-owned enterprise, thus

687 "Rich Province, Poor Province," The Economist, October 1, 2016, https://www.economist.com/news/china/21707964-government-struggling-spread-wealth-more-evenlyrich-province-poor-province

688 "Xinhua Insight: Poverty Relief High on China’s Policy Agenda," Xinhuanet, July 22, 2016, http://www.xinhuanet.com/english/2016-07/22/c_135533434.htm

${ }^{689}$ See: Yuqing Wu, "Ten Years After "Go West,"' Journal of the Washington Institute of China Studies 4(2), 2009, p. 3-4; Bhajan S. Grewal and Abdullah D. Ahmed, "Is China's Western Region Development Strategy on Track? An Assessment," Journal of Contemporary China 20(69), 2011, p. 165-166

${ }^{690}$ See: Yuqing Wu, "Ten Years After "Go West,"” Journal of the Washington Institute of China Studies 4(2), 2009, p. 3-4; Bhajan S. Grewal and Abdullah D. Ahmed, "Is China's Western Region Development Strategy on Track? An Assessment," Journal of Contemporary China 20(69), 2011, p. 165-166; Peter Cai, "Understanding China's Belt and Road Initiative," Lowy Institute, March 22, 2017, https://www.lowyinstitute.org/publications/understanding-belt-and-road-initiative\#_edn19 
increasing the province's reliance on SOEs. Furthermore, the heavy subsidies that different sectors receive in these provinces in order to make up for the restructuring of the tax code result in a poor investment environment for foreign firms, thus compounding the problem. ${ }^{691}$ In 2016, western provinces like Xinjiang, Tibet, Qinghai, and Gansu ranked the lowest in the China Economic Research Institute's Free Market Index, with the average score of 2.67 compared to the national average of $6.56 .{ }^{692}$

These problems resulted in the increased dependency of western provinces and solidified their role as primarily raw material producers meant to support the developed coastal provinces. This is not surprising considering that two of the major projects proposed under the GWD strategy were the West-East gas pipelines as well as the West-East electricity transmission project. In fact, China's heavy focus on mitigating the challenge of the Malacca Dilemma during Hu Jintao's tenure resulted in heavy investment in domestic hydrocarbons extraction in places like Xinjiang and Sichuan. Furthermore, once China began looking to Central Asia for energy security, China's western provinces, especially Xinjiang, would become energy hubs that would receive, process, and transfer energy and electricity to the coastal regions. In other words, this type of dependency was built into the GWD strategy even if it was intended to serve as a catalyst for greater economic development.

Despite these shortcomings, however, the infrastructure was in place to pursue greater economic integration into Eurasia, such as highways, railways, and border

\footnotetext{
${ }^{691}$ Peter Cai, “Understanding China's Belt and Road Initiative,” Lowy Institute, March 22, 2017, https://www.lowyinstitute.org/publications/understanding-belt-and-road-initiative\#_edn19

${ }^{692}$ Ibid. (a rank of 0 means no private enterprise, 10 means completely free)
} 
landports. Furthermore, the means to exercise effective control of the minority regions reduced the potential danger of such integration. Therefore, the GWD strategy paved the way for the emergence of the Belt Road Initiative. As with the GWD strategy, however, there was a need to develop accompanying policy, projects, and supporting institutions in order to make the transition from policy to practice. In other words, there was a need for an accompanying region-building project.

\section{The Silk Road Economic Belt and the $21^{\text {st }}$ Century Maritime Silk Road}

On October 2, 2013, a month after proposing the Silk Road Economic Belt, Xi Jinping announced its maritime counterpart, the "Maritime Silk Road of the $21^{\text {st }}$ century," in a speech to the Indonesian parliament. The speech was similar to the one he gave at Nazarbayev University. Xi Jinping highlighted the historical ties between China and its ASEAN neighbors, stating that "Southeast Asia has since ancient times been an important hub along the ancient Maritime Silk Road. ${ }^{\prime 693} \mathrm{He}$ added that the focus of China-ASEAN relations should be to build trust and develop good neighborliness as well as strive for winwin cooperation. Additionally, Xi reiterated China's respect for the plurality of development models contending that there was "no one-size-fits-all development model in the world" and that countries should follow "development paths in light of their specific national conditions. ${ }^{{ }^{694}}$ In other words, just like in his proposal for the Silk Road Economic Belt, Xi was urging ASEAN countries to communicate with China and each other,

\footnotetext{
693 "Speech by Chinese President Xi Jinping to Indonesian Parliament," ASEAN-China Centre, October 3, 2013, http://www.asean-china-center.org/english/2013-10/03/c_133062675.htm

${ }^{694}$ Ibid.
} 
regarding their development strategies in order to assess how they might complement and support each other. Furthermore, much like the Silk Road Economic Belt, the $21^{\text {st }}$ Century Maritime Silk Road was intended to increase connectivity, particularly between China, ASEAN, South Asian, Southwest Asia, East Africa, and Europe through the maritime commons. Although this study focuses on the overland routes of the Silk Road Economic Belt, Xi's proposal of the $21^{\text {st }}$ Century Maritime Silk Road is important since it complements a number of the economic corridors that make up the former. Moreover, Xi's proposal to the Indonesian Parliament revealed another key component of his overall vision for Eurasian connectivity: the Asian Infrastructure Investment Bank (AIIB).

The proposal of this bank is critical for two reasons. On one hand, it provides a financial institution that can help bridge the gap in infrastructure funding that the Asian Development Bank (ADB) identified in its 2013 report. The ADB report indicated that between 2013 and 2020, there would be an $\$ 8$ trillion gap in infrastructure funding in Asian countries. ${ }^{695}$ The AIIB, with its focus on infrastructure was essentially targeting this gap. On the other hand, the announcement of this bank was an explicit rebuttal to what Chinese authorities perceived as the poor treatment China received in western-led financial institutions. China, despite emerging as the second largest economy of the world, possessed a disproportionately small amount of voting power at the IMF and World Bank. Consequently, the AIIB represented an important first step in China's efforts to play a greater role in global finance and consequently begin to change its landscape. ${ }^{696}$

\footnotetext{
695 “Who will Pay for Asia’s \$8 Trillion Infrastructure Gap," Asian Development Bank, September 30, 2013, https://www.adb.org/news/infographics/who-will-pay-asias-8-trillion-infrastructure-gap

${ }^{696}$ Daniel C.K. Chow, "Why China Established the Asia Infrastructure Investment Bank," Vanderbilt Journal of Transnational Law 59, 2016, p. 1255-1298
} 
Following his ASEAN tour, Xi Jinping returned to China for the $3^{\text {rd }}$ plenary session of the 18th Central Committee of the Chinese Communist Party. The report of the session, released on November 13, 2013, called for the opening of border areas at a quicker pace, adding that the central government would set up development-oriented financial institutions to "accelerate the construction of infrastructure connecting China with neighboring countries and regions, and work hard to build a Silk Road Economic Belt and a Maritime Silk Road, so as to form a new pattern of all-round opening. ${ }^{~} 697$ The inclusion of the silk road initiatives into the national reform plan indicated its importance to China's development in the $21^{\text {st }}$ century, and consequently, for the achievement of the Chinese dream of national rejuvenation, something that is reiterated in the report. ${ }^{698}$

On March 5, 2014, as part of his annual reports on the work of the government, $\mathrm{Li}$ Keqiang made the first official reference to the "economic corridors" that will be part of Silk Road Economic Belt and the $21^{\text {st }}$ Century Maritime Silk Road, identifying the ChinaPakistan Economic Corridor (CPEC) and the Bangladesh-China-India-Myanmar Economic Corridor (BCIMEC). According to the work report, the central government would launch major projects in order to speed up infrastructure connectivity with China's neighbors. ${ }^{69}$ As central authorities moved towards greater clarity of what these initiatives

\footnotetext{
697 "Decision of the Central Committee of the Communist Party of China on some Major Issues Concerning Comprehensively Deepening the Reform, USC US-China Institute, November 12, 2013, https://china.usc.edu/decision-central-committee-communist-party-china-some-major-issues-concerningcomprehensively

${ }^{698}$ Ibid.

${ }^{699}$ Keqiang Li, "Full Text: Report on the Work of the Government (2014)," The National People's Congress of the people's Republic of China, March 18, 2014, http://www.npc.gov.cn/englishnpc/Speeches/2014-03/18/content_1856703.htm
} 
would entail, the need to establish supporting institutions increased. On October 24, 2014, $\mathrm{Xi}$ Jinping met with representatives from twenty-one countries in order to sign a memorandum of understanding on the establishment of the AIIB. In reference to the bank's focus on infrastructure and its linkage to economic development, Xi stated that "to build fortune, roads should be built first." 700 During this signing ceremony, Xi Jinping recognized that China's development was contingent on Asia's development, a perspective that became increasingly relevant during this phase of China's Eurasian foreign policy. In other words, Asia's development was crucial to achieving the Chinese dream. Thus, Xi urged attendees to pursue an open strategy of mutual benefit and win-win results. ${ }^{701}$ The AIIB would have an initial capital of $\$ 100$ billion, provided entirely by China and supplemented by other signatories once the bank was formally established. ${ }^{702}$

A mere two weeks after this ceremony, Xi Jinping, while hosting the "Dialogue on Strengthening Connectivity Partnership" in Beijing, announced that in addition to the AIIB, China would set up an Silk Road Fund (SRF) and contribute $\$ 40$ billion. ${ }^{703}$ On December 29,2014 , the SRF was established with an initial capital installment of $\$ 10$ billion provided by various state agencies, banks and SOEs. ${ }^{704}$ This fund was solely focused on the projects

\footnotetext{
700 "Xi Jinping Meets with Representatives from Various Countries Attending the Signing Ceremony of the MOU on Preparing to Establish the Asian Infrastructure Investment Bank," Ministry of Foreign Affairs of the people's Republic of China, October 24, 2014, http://www.fmprc.gov.cn/mfa_eng/zxxx_662805/t1204639.shtml

701 Ibid.

702 Daniel C.K Chow, "Why China Established the Asia Infrastructure Investment Bank," Vanderbilt Journal of Transnational Law 59, 2016, p. 1255-1298

703 "Fund History," Silk Road Fund, http://www.silkroadfund.com.cn/enweb/23775/23778/index.html

704 “Overview," Silk Road Fund, http://www.silkroadfund.com.cn/enweb/23775/23778/index.html
} 
outlined for the Silk Road Economic Belt and the $21^{\text {st }}$ Century Maritime Silk Road. The creation of the AIIB and SRF also plays an important role in the internationalization of the yuan since both of these institutions can issue yuan-denominated loans. ${ }^{705}$ The ability to do this is important since it is clear that Xi Jinping sees the benefits of relying on local currencies for regional trade. As Xi indicated during his announcement of the Silk Road Economic Belt in 2013, if the region can "realize local-currency convertibility and settlement under current and capital accounts, it will significantly lower circulation costs, increase our ability to fend off financial risks and make our region more economically competitive in the world."706 This indicates an implicit effort to reduce the dominant role that the dollar plays in global finance and a willingness by Chinese officials to gradually increase their footprint in this important sector.

By 2015, Li Keqiang's report on the work of the government highlighted the achievement of the establishment of these financial institutions that would support projects for greater connectivity between China and its neighbors. The report again reiterated the importance of continuing to open up the frontier regions in order to make progress on the CPEC and BCIMEC. More importantly, this report implicitly indicated that the GWD strategy and other development strategies such as the "Northeast Area Revitalization Plan" (2003) and the "Rise of Central Asia Plan" (2004), would be subsumed by the Silk Road Economic Belt and the $21^{\text {st }}$ Century Maritime Silk Road. Li Keqiang stated that central

\footnotetext{
705 Cary Huang, "China Seeks Role for Yuan in AIIB to Extend Currency's Global Reach," South China Morning Post, April 14, 2015, http://www.scmp.com/news/china/economy/article/1766627/china-seeksrole-yuan-aiib-extend-currencys-global-reach

706 Jiao Wu, "Xi Proposes a 'New Silk Road' with Central Asia,” China Daily USA, September 8, 2013, http://usa.chinadaily.com.cn/china/2013-09/08/content_16952304.htm
} 
authorities would "integrate the development of the Silk Road Economic Belt and the $21^{\text {st }}$ Century Maritime Silk Road with the development and opening up of related regions," adding that they would also promote the development of the New Eurasian Land Bridge as well as major coastal and border ports that served as hubs for the initiative. ${ }^{707}$ This highlighted the importance of the western provinces, especially Xinjiang, to the new initiatives since it served as the gateway to Eurasia.

\section{Refining the Vision}

Following Li Keqiang's 2015 government report, the most important document outlining the goals of the Silk Road Economic Belt and the $21^{\text {st }}$ Century Maritime Silk Road emerged. On March 28, the State Council authorized a document titled "Vision and Actions on Jointly Building Silk Road Economic Belt and $21^{\text {st }}$ Century Maritime Road." The document was important because it set out the normative foundations of the initiative, in addition to expanding information on the goal of increasing connectivity between China and the rest of Eurasia through integrative infrastructure. It began by connecting the initiative to the "Silk Road Spirit," which was defined by peace and cooperation, openness and inclusiveness, as well as mutual learning and mutual benefit. According to the document, the Silk Road Spirit contributed greatly to the prosperity and development of the historical Silk Road. ${ }^{708}$ In many ways this alluded to the Shanghai Spirit that served as

\footnotetext{
${ }^{707}$ Keqiang Li, "Full Text: Report on the Work of the Government (2015)," The State Council of the People's Republic of China, March 16, 2015, http://english.gov.cn/archive/publications/2015/03/05/content_281475066179954.htm

708 "Vision and Actions on Jointly Building Silk Road Economic Belt and $21{ }^{\text {st }}$ Century Maritime Road," National Development and Reform Commission of the People's Republic of China, March 28, 2015, http://en.ndrc.gov.cn/newsrelease/201503/t20150330_669367.html
} 
the foundation for the SCO, as indicated in the previous chapter. The purpose was to create an environment that was conducive for China to engage Eurasian states more effectively in order to generate domestic economic development. However, China was also promising development of Eurasian countries which sought to participate in the initiative.

In addition to the Silk Road Spirit, the vision referred to the emergence of a multipolar world and that China was "committed to shouldering more responsibilities and obligations," as well as "making greater contributions to the peace and development of mankind." ${ }^{709}$ Like many of China's various agreements with other countries, the document indicated that the Silk Road Economic Belt and the $21^{\text {st }}$ Century Maritime Silk Road was in line with the purposes and principles of the UN Charter as well as the five principles of peaceful coexistence. In other words, the initiative would respect the sovereignty and territorial integrity of participant states and stated that China would not interfere in their domestic affairs. Furthermore, the document reiterated China's position that the development models chosen by different countries should be respected, stressing that through communication and coordination, states could manage their development strategies in ways that would be mutually beneficial. Ultimately, the purpose of the initiative was to promote the common development and prosperity of the participant states through win-win cooperation. Lastly, the vision connected the initiative to the securitydevelopment nexus logic by alluding that the objectives of mutual benefit and development would result in the common security of the participants. ${ }^{710}$

\footnotetext{
${ }^{709}$ Ibid.

${ }^{710}$ Ibid.
} 
The use of these varying discourses as the normative foundation of the Silk Road Economic Belt and the $21^{\text {st }}$ Century Maritime Silk Road, revealed significant overlap in China's many international agreements. In essence, it demonstrated a consistency in the rhetoric of CCP leadership even if the scope of this phase of its Eurasian region-building project was far more ambitious than any before it. These narratives were important. As indicated in the previous chapter, they served the dual purpose of legitimizing Chinese domestic policies, but also facilitated engagement with its neighbors. Furthermore, in addition to remaining rhetorically consistent, the PRC has demonstrated its willingness to follow through with this rhetoric, thus according it with a measure of international credibility, especially in the global south. ${ }^{711}$ Lastly, at a fundamental level, many of these norms were explicit critiques of the Western-led liberal-normative order. The inherent critique was against the universalist claims that underpin the Washington Consensus, the regular military intervention by Western forces in developing countries, the political and economic conditions attached to aid and investment packages for developing countries, and the status quo mentality that China claimed dominated American thinking and produced policies of containment. Consequently, China emerged as a protector of political and development pluralism in addition to safeguarding national sovereignty and territorial integrity, international norms that, ironically, were pioneered by the West through their propagation of the Westphalian state system.

In addition to establishing the normative foundations of the region-building project, the plan also revealed the six economic corridors envisioned for the Silk Road Economic

\footnotetext{
${ }^{711}$ Emily T. Yeh and Elizabeth Wharton, "Going West and Going Out, Migrants, and Models of Chinese Development," Eurasian Geography and Economics 57(3), 2016, p. 286-315
} 
Belt and the $21^{\text {st }}$ Century Maritime Silk Road. As well as establishing the New Eurasian Land Bridge (NELB), CPEC, and BCIMEC, the initiative adds the China-Mongolia-Russia Economic Corridor (CMREC), China-Central Asia-West Asia Economic Corridor (CCAWAEC), and the China-Indochina Peninsula Economic Corridor (CIPEC). According to the report the "Silk Road Economic Belt focuses on bringing together China, Central Asia, Russia and Europe (the Baltic); linking China with the Persian Gulf and the Mediterranean Sea through Central Asia and West Asia; and connecting China with Southeast Asia, South Asia and the Indian Ocean." ${ }^{712}$ In other words, the six corridors would link China to all of the Eurasian sub-regions and as a result, to each other (see map 9). These corridors would take advantage of international transport routes, many of which would need to be built or upgraded in order to fulfil the needs of the initiative. Furthermore, the corridors would rely on core cities along the routes where China and its partners would build industrial parks and cooperation platforms in order to promote economic activity. This indicated that in addition to building and upgrading new transportation routes, China was also seeking to establish new supply chains along Eurasia, thus outlining the empirical component of the region-building project.

On the surface, promoting the creation of these new supply chains does not appear controversial, after all, there are few, if any, economic hubs along Eurasia's center. ${ }^{713}$ Using the popular American expression for its interior states, Eurasia's center is essentially

\footnotetext{
712 "Vision and Actions on Jointly Building Silk Road Economic Belt and $21^{\text {st }}$ Century Maritime Road," National Development and Reform Commission of the People's Republic of China, March 28, 2015, http://en.ndrc.gov.cn/newsrelease/201503/t20150330_669367.html

${ }^{713}$ Eurasia's center refers to the geographical space spanning from Urumqi, China to Kars, Turkey (EastWest axis), and Yekaterinburg, Russia to Gwadar, Pakistan (North-South axis)
} 
"flyover" country. However, in the context of Xi Jinping's recognition that China's development was contingent of the development of Asia, an important transformation in the understanding of the security-development nexus logic in the upper echelons of CCP leadership has emerged. As previous chapters have established, the security-development nexus logic, within the $\mathrm{CCP}$, refers to the co-constitutive relationship between economic development, social stability and security. Thus, you need one to have the other and vice versa. In this dynamic, the CCP provides the conditions for both, thus generating legitimacy and ensuring its political survival. During the first phase of China's Eurasian foreign policy, this nexus was almost entirely domestically focused. In other words, security and development could be obtained through central investment and increased control in the western provinces.

This logic began to shift over time, especially during the second phase, when the $\mathrm{CCP}$ recognized that the task of developing the western provinces required FDI and greater connectivity to neighboring countries, in addition to diversifying its energy supply. What mattered for China during this phase was the political stability of its western neighbors, their cooperation against the three evils, and their role as energy suppliers to China's economic development. However, as the Chinese dream of national rejuvenation, through meeting the two centennial goals, became the hallmark of Xi Jinping's administration, the security-development nexus logic shifted. The need to link western China to Eurasian markets had not changed, but in realizing that the markets were largely absent themselves, China resolved to create them. In other words, the development and stability of China's western regions was understood as being contingent on the economic development and stability of its neighbors. 
It was here that the Silk Road Economic Belt and the $21^{\text {st }}$ Century Maritime Silk Road made their mark on Xi Jinping's efforts to achieve the Chinese dream, by promoting the economic growth of its neighbors, especially along the Eurasian center, China's western provinces could also develop and vice versa. ${ }^{714}$ In other words, the Silk Road Economic Belt and the $21^{\text {st }}$ Century Maritime Silk Road could be understood as both, a state-building and a region-building project. This marked a decisive shift in China's foreign policy approach, especially since it moved away from Deng Xiaoping's maxim, and pushed for a more proactive international agenda. Furthermore, it also rebalanced China's engagement in Eurasia from an overwhelming focus on extraction in the energy sector, to more projects aimed at interconnectivity, market access, and economic development.

The vision document also made one last contribution, that although seemingly minor, underwent important discussion: the abbreviation. The Silk Road Economic Belt and the $21^{\text {st }}$ Century Maritime Silk Road was not something that generated a simple abbreviation. However, for the first two years after its announcement by Xi, it was regularly shortened to One Belt One Road, or OBOR. However, there appear to have been some internal discussions about how the term was translated to English and its ability to convey the nature of the initiative. The solution was devised by the Central Compilation and Translation Bureau of the People's Republic of China. The bureau concluded that the Silk Road Economic Belt and the $21^{\text {st }}$ Century Maritime Silk Road should be referred to as the Belt Road Initiative, or BRI, in all English translations referring to the initiative. The concern regarding the English translation into OBOR revolved around the fact that the

\footnotetext{
${ }^{714}$ Rafaello Pantucci, "Central Asia: The View from China," European Union Institute for Security Studies, 2015, p. 1, https://www.iss.europa.eu/sites/default/files/EUISSFiles/Alert_3_Central_Asia_China.pdf
} 
initiative involved numerous economic corridors. By appearing as a single road and belt, there was concern that the initiative would be perceived as a limited offer that would drive increased competition among regional partners. Lastly, by adding "initiative" into the new shorthand, Chinese officials hoped that they could convey the openness of the project and thus avoid criticism over a "China-centered institution building" agenda. ${ }^{715}$ This change in shorthand was done in time to make it into the vision document. ${ }^{716}$

\footnotetext{
715 Wade Shepard, "Beijing to the World: Don't Call the Belt and Road Initiative OBOR," Forbes, August 1, 2017, https://www.forbes.com/sites/wadeshepard/2017/08/01/beijing-to-the-world-please-stop-sayingobor/\#3db282bc17d4

716 "Vision and Actions on Jointly Building Silk Road Economic Belt and $21^{\text {st }}$ Century Maritime Road," National Development and Reform Commission of the People's Republic of China, March 28, 2015, http://en.ndrc.gov.cn/newsrelease/201503/t20150330_669367.html
} 


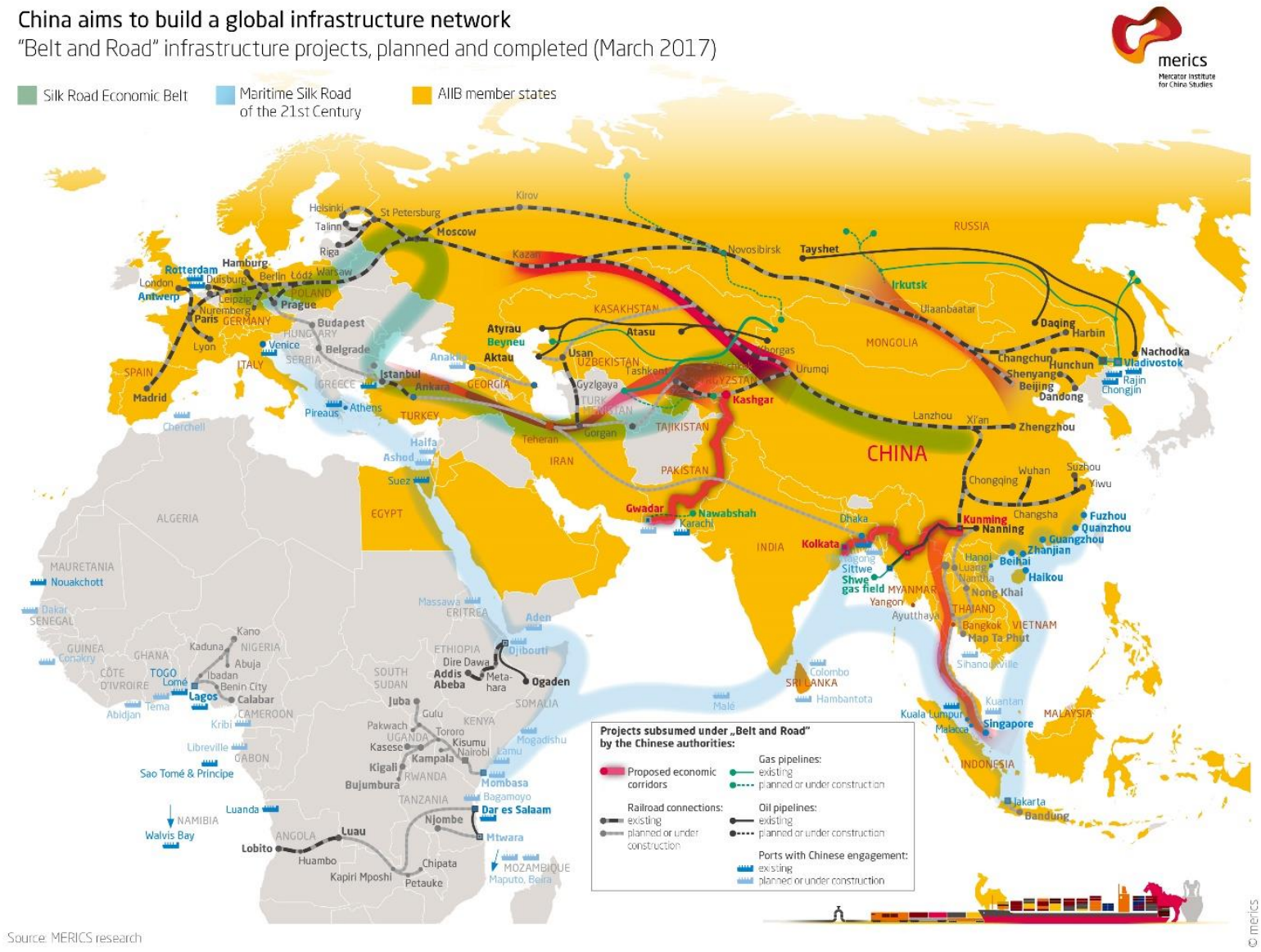

Map 9: Six Proposed Economic Corridors of the BRI. Source: https://www.merics.org/sites/default/files/201708/170515_MERICS_China_Mapping_BRI_March_2017_0.jpg

\section{Development and Re-connecting Eurasia}

At its core the BRI is a collection of projects that aim to generate development in Eurasia by increasing market connectivity and providing the foundations for greater economic activity. The economic corridors serve as the umbrella under which Chinese, as well as foreign investment, is placed in specific Eurasian sub-regions. Furthermore, based on the proposed corridors it is evident that the underdeveloped provinces within China are the gateway to these sub-regions, particularly for the Silk Road Economic Belt component of the initiative. Consequently, Eurasian sub-regions are being connected to China's sub- 
national regions in order to obtain economic co-development. China's coastal regions are also being connected to these emerging markets. This demonstrates the most explicit mechanism through which the state-building and region-building project are linked under the BRI. For example, one of the many routes of the New Eurasian Land Bridge connects coastal cities like Lianyungang, Jiangsu, to Rotterdam, Netherlands after traversing central and western China, Kazakhstan, Russia, Belarus, Poland, and a number of European coastal ports like Antwerp, Belgium, before reaching its final destination. ${ }^{717}$ Thus, as China's Foreign Minister, Wang Yi (2013-present) has stated on a number of occasions, the BRI is intended to bring about the rejuvenation of the Eurasian continent; an explicit connection between the economic development of China and its Eurasian neighbors. ${ }^{718}$ More importantly, however, by virtue of its design, the BRI puts China at the center of Eurasian connectivity and economic development, thus placing China in a pivotal position in Eurasian affairs. ${ }^{719}$

\footnotetext{
717 “The Belt Road Initiative," Hong Kong Trade Development Council, September 13, 2017, http://chinatrade-research.hktdc.com/business-news/article/The-Belt-and-Road-Initiative/The-Belt-and-RoadInitiative/obor/en/1/1X000000/1X0A36B7.htm

${ }^{718}$ See: "Foreign Minister Wang Yi Meets the Press," Ministry of Foreign Affairs of the People's Republic of China, March 8, 2014, http://www.fmprc.gov.cn/mfa_eng/wjb_663304/wjbz_663308/2461_663310/t1135385.shtml; "Foreign Minister Wang Yi Meets the Press," Ministry of Foreign Affairs of the People's Republic of China, March 8, 2015, http://www.fmprc.gov.cn/mfa_eng/zxxx_662805/t1243662.shtml; "Transcript of Foreign Minister Wang Yi's Interview with Belahodood of Al Jaazeera," Embassy of the People's Republic of China in the Republic of Indonesia, May 19, 2016, http://www.mfa.gov.cn/ce/ceindo/eng/xwdt/t1364778.htm

${ }^{719}$ Michael Clarke, "The Belt and Road Initiative and China's Xinjiang Dilemma: "Connectivity" Versus Control?” The Central Asia-Caucasus Analyst, July 17, 2017, https://www.cacianalyst.org/publications/analytical-articles/item/13458-the-belt-and-road-initiative-andchina\%E2\%80\%99s-xinjiang-dilemma-\%E2\%80\%9Cconnectivity\%E2\%80\%9D-versus-control?.html
} 


\section{Xinjiang and the Belt Road Initiative}

Since the six envisioned economic corridors link China's underdeveloped national sub-regions to other Eurasian sub-regions, it is clear that provinces like Yunnan and Guangxi will play a key role in the BCIMEC and CIPEC, while northeastern provinces, China's "rust belt," will be playing a key role in the CMREC. Nevertheless, it is Xinjiang that plays the most important role in the BRI. As the "Vision and Actions on Jointly Building Silk Road Economic Belt and $21^{\text {st }}$ Century Maritime Road” indicates, "Xinjiang's geographic advantages and its role as a window of westward opening-up to deepen communication and cooperation with Central, South and West Asian countries, make it a key transportation, trade, logistics, culture, science and education center, and a core area on the Silk Road Economic Belt." ${ }^{720}$ In fact, the 2017 "Report on China's Economic, Social Development Plan" designates Xinjiang as the core of the Silk Road Economic Belt component of the BRI. ${ }^{721}$ Thus, Xinjiang's strategic position makes it the pivot of the BRI much in the same way as its has been the pivot to most of China's western development policies since the 1990s. Out of the six proposed corridors, three of them place Xinjiang at the center: the NELB, CCAWAEC, and CPEC. However, for many CCP officials, Xinjiang's increased connectivity as a result of the proposed BRI corridors has raised some concern. This shares parallels with the first phase of opening up the province during the

\footnotetext{
720 "Vision and Actions on Jointly Building Silk Road Economic Belt and $21^{\text {st }}$ Century Maritime Road," National Development and Reform Commission of the People's Republic of China, March 28, 2015, http://en.ndrc.gov.cn/newsrelease/201503/t20150330_669367.html

721 “Full Text: Report on China’s Economic, Social Development Plan,” Xinhuanet, March 17, 2017, http://www.xinhuanet.com/english/china/2017-03/17/c_136137416_3.htm
} 
1990s in the sense that it was perceived that increased connectivity would also expose the province to potentially radical ideologies, thus feeding the three evils.

That Uyghurs have surfaced in ISIS training camps in Iraq and Syria has been particularly worrisome. On March 1, 2017, Chinese official's fears were validated when a video released by ISIS showed Uyghur fighters training in Iraq. The video went on to show statements by various Uyghur fighters, with one stating that "in retaliation for the tears that flow from the eyes of the oppressed, we will make your blood flow in rivers, by the will of God," in reference to the treatment received by Muslim minorities in Xinjiang. ${ }^{722} \mathrm{Xi}$ Jinping responded to this video by urging security forces to erect a "great wall of steel" in Xinjiang, referencing the rhetoric used by Deng Xiaoping and Wang Zhen post-Tiananmen, adding that "maintaining stability in Xinjiang is a political responsibility." 723 Cheng Guoping, State Commissioner for Counterterrorism and Security, stated that ETIM was the most "prominent challenge to China's social stability, economic development and national security," validating the need to exercise greater control in Xinjiang. ${ }^{724}$ As a result, the increased connectivity that is projected as a result of the BRI has simultaneously led to

\footnotetext{
${ }^{722}$ Michael Martina and Ben Blanchard, "Uighur IS Fighters Vow Blood will 'Flow in Rovers' in China," Reuters, March 1, https://www.reuters.com/article/us-mideast-crisis-iraq-china/uighur-is-fighters-vowblood-will-flow-in-rivers-in-china-idUSKBN16848H

${ }^{723}$ Tom Phillips, “China: Xi Jinping wants 'Great Wall of Steel' in Violence-hit Xinjiang," The Guardian, March 10, 2017, https://www.theguardian.com/world/2017/mar/11/china-xi-jinping-wants-great-wall-ofsteel-in-violence-hit-xinjiang

${ }^{724}$ John Ruwitch, Michael Martina, and Christian Shepherd, "China's Xi Calls for 'Great Wall of Iron' to Safeguard Restive Xinjiang,” Reuters, March 9, https://www.reuters.com/article/us-china-securityxinjiang/chinas-xi-calls-for-great-wall-of-iron-to-safeguard-restive-xinjiang-idUSKBN16H04J
} 
increased efforts to exercise control of the province by central authorities. ${ }^{725}$ The rhetoric by CCP officials indicate that this level of control is intended to create the conditions for successful economic investment, and thus generate economic development in the province. In other words, the security-development nexus logic continues to be the basis through which central authorities legitimize these policies.

Recognizing their position as the pivot of the BRI, Xinjiang's officials have formulated a construction plan making a bid for Urumqi's and Kashgar's designation as international transportation hubs in the initiative. The plan calls for national, regional, and local-level transport centers that will more effectively integrate Xinjiang into the BRI project and the rest of China. Its aim is to take advantage of Xinjiang's strategic position and transform it from a terminus in the Eurasian continent into a transportation hub that links north-south and east-west corridors. ${ }^{726}$ The plan envisions the creation of four northsouth corridors and four east-west corridors. Of north-south corridors:

\begin{abstract}
"one will run along China's border in line with on-going development and opening-up requirements, as well as national defense needs. Of the other three, one will provide RussiaChina-Pakistan connectivity, a second will address the need for an enhanced ChinaMongolia link, and the third will become a primary Mongolia-China-Pakistan trade route." 727
\end{abstract}

\footnotetext{
${ }^{725}$ See: Michael Clarke, "Why Xi Jinping's Belt and Road Rhetoric of Inclusion Rings Hollow among the Muslim Uyghurs of Xinjiang," South China Morning Post, June 7, 2017, http://www.scmp.com/comment/insight-opinion/article/2097229/why-xi-jinpings-belt-and-road-rhetoricinclusion-rings; Michael Clarke," The Belt and Road Initiative and China's Xinjiang Dilemma:

“Connectivity" Versus Control?" The Central Asia-Caucasus Analyst, July 17, 2017, https://www.cacianalyst.org/publications/analytical-articles/item/13458-the-belt-and-road-initiative-andchina\%E2\%80\%99s-xinjiang-dilemma-\%E2\%80\%9Cconnectivity\%E2\%80\%9D-versus-control?.html; "Belt, Road, and the Xinjiang Issue," Singapore Management University, August 31, 2017, https://www.smu.edu.sg/perspectives/2017/08/31/belt-road-and-xinjiang-issue
}

726 “Xinjiang's Construction Plan for Development of a Transport Center on the Silk Road Economic Belt from 2016-2030," Yidaiyilu, August 30, 2017, https://eng.yidaiyilu.gov.cn/zchj/dfgg/25503.htm

727 “Xinjiang Unveils Route Map for Bid to Become Key Belt and Road Transportation Hub,” Hong Kong Trade Development Council, July 17, 2017, http://china-trade-research.hktdc.com/business- 
The east-west corridors would allow for better infrastructure connecting Xinjiang to the three BRI economic corridors of which is it part. In order to make this vision a reality, Xinjiang officials indicated that the province's internal north-south connectivity needed to be upgraded. This also paves the way for greater integration of southern Xinjiang into the rest of the province and, by extension, the rest of the country since northern Xinjiang is well integrated into China's main transportation arteries. ${ }^{728}$

\section{The Shanghai Cooperation Organization and the Belt Road Initiative}

If Xinjiang is the gateway to Eurasia and the pivot for the BRI, the SCO is the vehicle that facilitates China's development goals in Eurasia by ensuring the security of China's borders, legitimizing its engagement in the region, and providing overland access to the EU, China's largest trade partner, ${ }^{729}$ through the NELB and the CCAWAEC. At the 2013 SCO Summit, immediately after announcing the BRI in Kazakhstan, Xi Jinping urged SCO members to sign an agreement facilitating international road transportation in order to make the transport corridors between the Pacific and the Baltic sea reality. ${ }^{730}$ In 2014 , the SCO followed through by signing the agreement, making it easier for carriers of SCO

\footnotetext{
news/article/The-Belt-and-Road-Initiative/Xinjiang-Unveils-Route-Map-For-Bid-to-Become-Key-Beltand-Road-Transportation-Hub-2016-2030/obor/en/1/1X000000/1X0ABJVK.htm

728 Ibid.

729 “China,” European Commission, http://ec.europa.eu/trade/policy/countries-and-regions/countries/china/ 730 “Xi Jinping Delivers Speech at SCO Summit, and Raises Four-Point Proposal," Ministry of the People's Republic of China, September 13, 2013, http://www.fmprc.gov.cn/mfa_eng/topics_665678/xjpfwzysiesgjtfhshzzfh_665686/t1077762.shtml
} 
members to conduct international transportation through members' territory. ${ }^{731}$ This was a positive step towards increasing trade activity for SCO carriers, especially for those trading with to South and Southwest Asia as well as Europe.

By the 2015 SCO Summit in Ufa, Russia, the declaration of the heads of states, as well as the SCO development strategy adopted by the group, expressed their support for China's BRI initiative. ${ }^{732}$ Successive declarations and agreements by the SCO since 2015 have reiterated their support for the BRI and called for greater coordination between members in order to make the initiative successful. In other words, after the announcement of the BRI, the SCO has continued to serve as a platform for China to secure support for initiatives in Eurasia and facilitate its engagement in the region. This support was important since at the time that the vision document was released in 2015, two of the BRI economic corridors required the support and participation of SCO member states. By 2017 the number of corridors that included SCO members increased to four when India and Pakistan formally acceded to the organization. ${ }^{733}$ Furthermore, through additional agreements on border security and information exchange since 2015, China has been able to mitigate some of its concerns emanating from Xinjiang's growing exposure to Eurasia as a result of the BRI. Therefore, even if the SCO has not served as the platform through which China can

\footnotetext{
731 "Agreement Between the Governments of the Member states of the Shanghai Cooperation Organization on Creating Favorable Conditions for International Road Transportation," The Shanghai Cooperation Organization, 2014, http://eng.sectsco.org/documents/

${ }^{732}$ See: "Ufa Declaration of the Heads of Member States of the Shanghai Cooperation Organization," The Shanghai Cooperation Organization, 2015, http://eng.sectsco.org/documents/; "Development Strategy of the Shanghai Cooperation Organization Until 2025, The Shanghai Cooperation Organization, 2015, http://eng.sectsco.org/documents/

733 "The Astana Declaration of the Heads of State of the Shanghai Cooperation Organization," The Shanghai Cooperation Organization, 2017, http://eng.sectsco.org/documents/
} 
achieve tangible economic goals, it continues to serve in its capacity of ensuring cooperating against the three evils. As a result, it continues to have significant value for Beijing.

\section{$\underline{\text { Re-connecting the Eurasian Sub-Regions }}$}

The explicit goal of connecting China to varying Eurasian sub-regions has the added effect of re-connecting these sub-regions to each other, much in the same way as they had been during the height of the historical Silk Roads. It is not an accident that Chinese officials have referred to the Silk Road in decades of engagement with various countries along the historical Silk Road. This rhetoric carries a normative as well as physical component. The normative component is part of a long-running narrative that aims to make China a "natural" component of the Eurasian continent. Furthermore, by establishing the historicity of China's relation with its Eurasian neighbors, it is also making its engagement in Eurasia natural and therefore, legitimate. The physical component refers to attempts to revive the historical Silk Road in the contemporary period. Although this physical component was alluded to throughout the 1990s, especially during Li Peng's and Jiang Zemin's visits to Central Asia, it is only after the announcement of the BRI that there has been a national strategy to bring about the revival of the Silk Road. The overland and maritime components of the BRI essentially cover the historical trade routes of the Silk Road, however, for the purposes of this study, this section will focus on the three economic corridors in which Xinjiang plays a vital role. 


\section{The New Eurasian Land Bridge}

Out of the six proposed corridors, the New Eurasian Land Bridge is the most straight forward since it relies heavily on infrastructure that is already largely in place and focuses primarily on freight transportation to Western Europe. ${ }^{734}$ The NELB is often depicted as the connection between the Chinese coastal city of Lianyungang, Jiangsu, and Rotterdam, in the Netherlands. As indicated above, this line enters Central Asia through the Alashankou landport at the Kazakh-Xinjiang border and makes its way through Kazakhstan, Russia, and into the EU. In actuality, this line was inaugurated in 1990 and has been providing international transport services since 1992. The line was later upgraded during the GWD strategy when the Lanzhou-Xinjiang rail was electrified, making the entire route electrified. ${ }^{735}$ Although the line's volume has increased since its inauguration, the announcement of the BRI brings this line greater relevance since it has been expanded to connect a greater number of cities within China as well as Europe. Furthermore, the line also facilitates trade between countries along its route. ${ }^{736}$ Since the BRI began to take shape, the NELB has referred to a multitude of railway routes that link various Chinese cities to Eurasian ones, with the farthest extent being Madrid, Spain. Moreover, as the linkages between the two extremes of the Eurasian landmass have expanded, the importance of the

\footnotetext{
734 "Fact Sheet: The New Eurasian Land Bridge," Geopolitical Monitor, February 7, 2018, https://www.geopoliticalmonitor.com/fact-sheet-the-new-eurasian-land-bridge/

735 Elena Ilie, "New Eurasia Land Bridge Provides Rail Connection Between China and Europe," Railway Pro, July 15, 2010, https://www.railwaypro.com/wp/new-eurasia-land-bridge-provides-rail-connectionbetween-china-and-europe/

736 "New Eurasian Land Bridge," China.org, April 19, 2017, http://www.china.org.cn/english/china_key_words/2017-04/19/content_40651850.htm
} 
Horgos landport has increased after opening rail traffic in 2012. ${ }^{737}$ These linkages include:

(1) a freight route from Chongqing to Duisburg, Germany; (2) a route from Wuhan, Hubei, to Melnik and Pardubice in the Czech Republic; (3) a route from Chengdu, Sichuan, to Lodz, Poland; (4) a route from Zhengzhou, Henan, to Hamburg, Germany; (5) a route from Suzhou, Zhejiang, to Warsaw, Poland; (6) and a route from Yiwu, Zhejiang, to Madrid, Spain. ${ }^{738}$ Many of these lines were introduced before or right after the announcement of the BRI initiative, illustrating how the BRI has absorbed many of the national development programs.

The real change for the NELB began to happen in 2013. Before the initiative, many of the existing routes were slow and unreliable since train departure was tied to volume targets. The introduction of the Chengdu-Lodz line changed this practice by removing this barrier and posting its departure and arrival times. ${ }^{739}$ This had a spillover effect on the other lines. The result were immediate, according to Kazakhstan's administrator of the country's

\footnotetext{
${ }^{737}$ See: Wade Shepard, "Why the China-Europe 'Silk Road' Rail Network is Growing Fast," Forbes, January 28, 2016, http://www.forbes.com/sites/wadeshepard/2016/01/28/why-china-europe-silk-road-railtransport-is-growing-fast/\#7ede739b7f24; "Khorgos: The Biggest Dry Port in the World," South China Morning Post, http://multimedia.scmp.com/news/china/article/One-Belt-One-Road/khorgos.html

${ }^{738}$ See: Gabor Debreczeni, "The New Eurasian Land Bridge: Opportunities for China, Europe, and Central Asia," The Public Sphere Journal, 2016, http://publicspherejournal.com/wpcontent/uploads/2016/02/02.eurasian_land_bridge.pdf; Louis Chan, "Kazakhstan: A Modern Silk Road Partner," Hong Kong Trade Development Council, January 26, 2016, http://hkmb.hktdc.com/en/1X0A50Y2/hktdc-research/Kazakhstan-A-Modern-Silk-Road-Partner; Wade Shepard, "Why the China-Europe 'Silk Road' Rail Network is Growing Fast," Forbes, January 28, 2016, http://www.forbes.com/sites/wadeshepard/2016/01/28/why-china-europe-silk-road-rail-transport-isgrowing-fast/\#7ede739b7f24

${ }^{739}$ Wade Shepard, "Why the China-Europe 'Silk Road' Rail Network is Growing Fast," Forbes, January 28, 2016, http://www.forbes.com/sites/wadeshepard/2016/01/28/why-china-europe-silk-road-rail-transportis-growing-fast/\#7ede739b7f24
} 
national railway, Kazakhstan Temir Zholy (KTZ), the number of containers processed in Kazakhstan in 2011 was about 2,000, by 2016 the number had increased to $42,000 .{ }^{740}$

In addition to removing the volume barrier, China effectively lobbied its SCO members to make progress on a 2007 agreement on cooperation and mutual assistance in customs affairs as well as other documents that focus on customs and were subsequently signed. This has led to greater customs efficiency and streamlined the routes, thus making them more economically viable. In fact, the 2017 declaration of the heads of state at the SCO Summit in Astana noted the active efforts of its members in mitigating the effects of one of the biggest non-tariff barriers to trade. ${ }^{741}$ As a result, the many lines that comprise the NELB have gradually become privately sustainable ventures since $2013 .{ }^{742}$ Furthermore, major companies have been using the NELB since the reforms began to take place. For example, Chongqing-Duisburg line, operated by a joint venture between Deutsche Bahn and Russian Railways, receives customers like Foxconn, Hewlett-Packard, and Acer. And the Chengdu-Poland line, operated by Hatrans, a Polish company, receives customers like DHL, Philips, Ericsson, Seagate, Samsung, and FIAT. ${ }^{743}$ This demonstrates

\footnotetext{
740 Ibid.

741 "The Astana Declaration of the Heads of State of the Shanghai Cooperation Organization," The Shanghai Cooperation Organization, 2017, http://eng.sectsco.org/documents/

${ }^{742}$ Gabor Debreczeni, "The New Eurasian Land Bridge: Opportunities for China, Europe, and Central Asia," The Public Sphere Journal, 2016, p. 44-45, http://publicspherejournal.com/wpcontent/uploads/2016/02/02.eurasian_land_bridge.pdf

${ }^{743}$ Keith Bradsher, "Hauling Treasure Along the Silk Road," The New York Times, July 20, 2013, http://www.nytimes.com/2013/07/21/business/global/hauling-new-treasure-along-the-silkroad.html?pagewanted=all; Gabor Debreczeni, "The New Eurasian Land Bridge: Opportunities for China, Europe, and Central Asia," The Public Sphere Journal, 2016, p. 45, http://publicspherejournal.com/wpcontent/uploads/2016/02/02.eurasian_land_bridge.pdf
} 
that although the NELB routes do not process the same volume of containers that major Chinese seaports do, they are profitable and have gradually expanded as a result of growing development in China's interior provinces. As labor costs increase in the coastal provinces, some production has moved inland; this is evident from cities like Chongqing and Chengdu establishing routes to Europe. Consequently, moving finished product to ports in the coast to ship them to Central Europe adds time and costs. ${ }^{744}$ According to Miklos Kopp, director of freight at the International Union Railways:

"sending a 10-ton 40-foot container from Chengdu, China, to Lodz, Poland, takes 12 to 14 days by train, compared to several days by plane (if you include customs and delivery on each end) and some six weeks or longer by boat. The price tag comes to some $\$ 40,000$ by air, compared to $\$ 10,000$ by train, and as low as $\$ 5,000$ by boat."

Kopp adds that shipping from the center of China to the center of Europe makes shipping by rail a good decision, although it will still be more expensive than shipping by boat. ${ }^{746}$ However, the speed advantages offered by rail freight, often less than half the time it takes a ship to reach Europe (45-50 days), makes it an attractive option for manufacturers of high-value goods like computers that need to reach their market destinations quickly. ${ }^{747}$ It

\footnotetext{
${ }^{744}$ Keith Bradsher, "Hauling Treasure Along the Silk Road," The New York Times, July 20, 2013, http://www.nytimes.com/2013/07/21/business/global/hauling-new-treasure-along-the-silkroad.html?pagewanted=all

745 Ian Mount, "Spain to China by Rail: A $21^{\text {st }}$ Century Silk Road Riddled with Obstacles," Fortune, December 24, 2014, http://fortune.com/2014/12/24/spain-china-rail-trade/

${ }^{746}$ Ibid.

${ }^{747}$ See: Cordula Rastogi and Jean-Francois Arvis, "The Eurasian Connection: Supply-Chain Efficiency Along the Modern Silk Road through Central Asia," The World Bank, 2014, p. 1, http://documents. worldbank.org/curated/en/730031468030581540/pdf/888910PUB0Box300EPI199120Jun e122014.pdf; Andrew Higgins, "China's Ambitious New 'Port': Landlocked Kazakhstan,” The New York Times, January 1, 2018, https://www.nytimes.com/2018/01/01/world/asia/china-kazakhstan-silk-road.html
} 
is, therefore, unsurprising that the majority of the customers identified above come from the electronics sector. Other time sensitive but heavy products, like car parts and processed foods benefit greatly from using freight rather than the slower option offered by ships, or the highly expensive option offered by planes. ${ }^{78}$ In other words, rail freight provides an economically viable medium of transportation to producers in economic sectors that sell value-added goods. In fact, a comprehensive World Bank study of the railways along the BRI conducted in 2014 indicated that the speed and cost per kilometer along the railway routes offer an excellent value, especially for Central Asian countries that sought to trade with Europe. ${ }^{749}$ Furthermore, the NELB serves an important strategic role through mitigating China's Malacca Dilemma by providing overland routes.

The revitalization and expansion of the NELB under the BRI has had an important impact on Kazakhstan, the only Central Asian republic through which the current NELB routes traverse. The growth in Kazakhstan's rail transport sector has led to the employment of roughly 160,000 workers, representing $2 \%$ of the country's workforce. Much of this is related to the China-EU trade and has resulted in substantial profits for the country. ${ }^{750} \mathrm{In}$ fact, the expansion and success of Kazakhstan's railway sector has emboldened President

\footnotetext{
${ }^{748}$ Gabor Debreczeni, "The New Eurasian Land Bridge: Opportunities for China, Europe, and Central Asia," The Public Sphere Journal, 2016, p. 45, http://publicspherejournal.com/wpcontent/uploads/2016/02/02.eurasian_land_bridge.pdf

${ }^{749}$ Cordula Rastogi and Jean-Francois Arvis, "The Eurasian Connection: Supply-Chain Efficiency Along the Modern Silk Road through Central Asia," The World Bank, 2014, p. 1-111, http://documents.worldbank.org/curated/en/730031468030581540/pdf/888910PUB0Box300EPI199120Jun e122014.pdf

${ }^{750}$ Gabor Debreczeni, "The New Eurasian Land Bridge: Opportunities for China, Europe, and Central Asia," The Public Sphere Journal, 2016, p. 48, http://publicspherejournal.com/wpcontent/uploads/2016/02/02.eurasian_land_bridge.pdf
} 
Nazarbayev who has sought to make Kazakhstan a hub in Eurasian transportation. ${ }^{751}$ On January 17, 2018, Nazarbayev facilitated a deal between KTZ and GE valued at $\$ 900$ million that will modernize Kazakhstan's existing fleet of locomotives, expand production facilities in Kazakhstan as well as service and maintain them. ${ }^{752}$ Kazakhstan's relationship with GE dates back to the 1990s, but this relationship became increasingly relevant after the BRI was announced, leading to GE opening a plant in Astana geared towards producing diesel engines for locomotives in $2015 .{ }^{753}$ Consequently, China's revitalization and expansion of the NELB has produced tangible benefits to Kazakhstan's economic stability and development.

Although the numerous NELB routes begin in different cities throughout China, they all converge on the Lanzhou-Xinjiang line before making their way to the ChineseKazakh border. This means that Xinjiang is servicing larger and larger volumes of cargo annually. As a result, one of the key projects of the NELB under the BRI has been the expansion of the Horgos landport. Located near the Eurasian Pole of Inaccessibility, the farthest point on earth from an ocean, the Horgos landport seems like an unlikely place to become the central hub of China's Eurasian transportation network. However, during the

\footnotetext{
${ }^{751}$ See: Louis Chan, "Kazakhstan: A Modern Silk Road Partner," Hong Kong Trade Development Council, January 26, 2016, http://hkmb.hktdc.com/en/1X0A50Y2/hktdc-research/Kazakhstan-A-Modern-Silk-RoadPartner; Evelyn Cheng, "Kazakhstan Pushes for US Deals- Helped by China's Investments," CNBC, January 31, 2018, https://www.cnbc.com/2018/01/31/kazakhstan-pushes-for-us-deals--helped-by-chinasinvestments.html

752 Azamat Batyrov, "Kazakhstan Will Upgrade Railways, Thanks to Deals with General Electric," Caspian News, January 22, 2018, https://caspiannews.com/news-detail/kazakhstan-will-upgrade-railways-thanks-todeals-with-general-electric-2018-1-21-54/

${ }^{753}$ Ibid.
} 
GWD strategy, the port transformed itself from a mere border check-point to the largest landport by highway traffic. Then, in 2012, railway operations in Horgos began, linking it to the NELB. That same year, it also became a Sino-Kazakh free trade zone (FTZ). By 2013, the China-Kazakhstan Horgos Frontier International Cooperation Center opened its doors. ${ }^{754}$ This allowed merchants and customers to cross the border without needing a visa for a single-day visit in order to access the duty-free shops that sprang up on both sides of the border. According to Guo Jianbin, deputy director of the Management Committee of the Horgos Economic Development Zone, the center has received more than 10 million visitors since $2013 .^{755}$ The ease of customs has also helped local businesses on both sides trade across their respective borders, something that has helped generate technology startups in Xinjiang which find easier access to their customers in Central Asia, Southwest Asia, and Europe through the landport. ${ }^{756}$

This increased cross-border activity has led to the port's increased relevance not only for the NELB, but also for the CCAWAEC. In the summer of 2017, the China Ocean Shipping Company (COSCO), along with Jiangsu Lianyungang Port Company, signed a contract with KTZ to buy a $49 \%$ stake in the Kazakh side of the port. This marked the first

\footnotetext{
754 “China-Kazakhstan Border Co-Operation in Xinjiang,” Hong Kong Trade Development Council, March 15, 2016, http://hkmb.hktdc.com/en/1X0A5JIX/hktdc-research/China-Kazakhstan-Border-Co-operation-inXinjiang

755 See: Wade Shepard, "Khorgos: The New Silk Road's Central Asian Station Comes to Life, Forbes, February 20, 2017, https://www.forbes.com/sites/wadeshepard/2017/02/20/khorgos-the-new-silk-roadscentral-station-comes-to-life/\#54f6e3c4c22e; Wang Cong, "Free Trade Zone Links Consumers in China, Kazakhstan," Global Times, May 2, 2017, http://www.globaltimes.cn/content/1045034.shtml

756 Nian Yao, “Xinjiang's Horgos Land Port Helps Boost Local Economy,” China Global Television Network, June 14, 2017, https://news.cgtn.com/news/3d676a4d3549444e/share_p.html
} 
time that COSCO invested in a landport, signifying the growing relevance of the overland routes for China's global trade. The increased efficiency of the port is expected to make the trip between Lianyungang on China's eastern coast to Central Europe in 15 days. ${ }^{757}$ Although the differences in rail gauge between China and its Eurasian neighbors has posed a logistical hurdle, the "Khorgos Gateway," the Kazakh side of the port, has mitigated much of the delay associated with transferring cargo from one train to another. By 2016, the port was capable of making the entire transfer in 47 minutes. ${ }^{758}$ As a result of the increasing efficiency, speed, and the reduction of non-tariff barriers, the revitalization and expansion of the NELB has resulted in an increasing number of trade routes servicing Chinese and European cities and others along the way. This is evident by the fact that by 2017 there were at least 39 China-Europe routes in operation in the NELB. ${ }^{759}$

\section{The China-Central Asia-West Asia Economic Corridor}

The China-Central Asia-West Asia Economic Corridor is perhaps the BRI's most ambitious corridor. This corridor aims to link China, the five Central Asian republics, as well as Iran and Turkey, in addition to facilitating access to European markets through a southern alternative to the NELB. Furthermore, Azerbaijan, Georgia, and Ukraine have

\footnotetext{
757 “Chinese Companies Buy Stake in Dry Port in Kazakhstan," China Daily, May 15, 2017, http://www.chinadaily.com.cn/business/2017-05/15/content_29355527.htm

758 Wade Shepard, "Why the China-Europe 'Silk Road' Rail Network is Growing Fast," Forbes, January 28, 2016, http://www.forbes.com/sites/wadeshepard/2016/01/28/why-china-europe-silk-road-rail-transportis-growing-fast/\#7ede739b7f24

${ }^{759}$ Wade Shepard, "Khorgos: The New Silk Road's Central Asian Station Comes to Life, Forbes, February 20, 2017, https://www.forbes.com/sites/wadeshepard/2017/02/20/khorgos-the-new-silk-roads-centralstation-comes-to-life/\#54f6e3c4c22e
} 
been incorporated as new routes are tested for their commercial viability. ${ }^{760}$ It important to note that while the NELB is almost entirely envisioned as a transport corridor that can facilitate export-led industries in China, as well as those of Kazakhstan and Europe, the CCAWAEC is more holistic. Thus, although transport infrastructure is still central to the corridor, the nature of the transport envisioned is more focused on regional interconnectivity as opposed to purely linking Chinese and European markets. Furthermore, the CCAWAEC aims to improve the infrastructure in various sectors in participating countries in order to improve local economic conditions. Being able to improve the local economic conditions is important for two reasons. First, as explained by the securitydevelopment nexus logic, development is expected to bring political and social stability. This is something that is important to China as political and social instability has the potential to spillover into China's western provinces as a result of increased globalization and interdependence. The second reason is that improved economic conditions increase living standards, leading to higher consumption rates. This means that China also aims to generate a new generation of consumers of Chinese products.

Central Asia is important to the success of the BRI. As immediate neighbors along China's western frontier, their development has become a priority for the BRI. From 20132015, Xi Jinping signed a number of bilateral agreements with his Kazakh, Uzbek, Kyrgyz, and Tajik counterparts aimed at supporting the BRI. Finally, at the $3^{\text {rd }}$ China-Central Asia

\footnotetext{
${ }^{760}$ See: Zhazira Dyussembekova, "Silk Road Renewed with New Commercial Transit Route," The Astana Times, January 21, 2016, http://astanatimes.com/2016/01/silk-road-renewed-with-launch-of-newcommercial-transit-route/; "The Belt Road Initiative," Hong Kong Trade Development Council, September 13, 2017, http://china-trade-research.hktdc.com/business-news/article/The-Belt-and-Road-Initiative/TheBelt-and-Road-Initiative/obor/en/1/1X000000/1X0A36B7.htm
} 
Cooperation Forum in Rizhao, Shandong, in 2015, all five republics expressed their commitment to "jointly building the Silk Road Economic Belt." since Turkmenistan, a crucial energy partner and the gateway to Southwest Asia, is not a member of the SCO, so its support through this forum is important for the future of the CCAWAEC. A facilitator for the CCAWAEC has been that the national development initiatives of Central Asian countries like Kazakhstan's "Bright Road", Tajikistan's "Energy, Transport and Food", and Turkmenistan's "Era of Might and Happiness," have significant overlap with the aims of the BRI. For example, Kazakhstan's Bright Road development initiative, announced by Nazarbayev on November 11, 2014, called for $\$ 3$ billion annual expenditures focused on infrastructure for three years. In fact, one of the programs that benefitted from this national development initiative was the Khorgos FTZ which saw a $\$ 477.7$ million investment. ${ }^{762}$

As a result of the complementarity as well as the proximity and importance of Central Asia to the CCAWAEC, China has invested heavily in projects in the region. Kazakhstan, as the most developed Central Asian republic, has been a key recipient of Chinese FDI following the announcement of the BRI. During his visit to Astana on December 14, 2014, Premier Li Keqiang and his Kazakh counterpart, Karim Masimov, signed a number of deals worth $\$ 14$ billion. This deal was important for a number of reasons. First, in addition to investments in Kazakhstan's natural resource sectors, the deal

\footnotetext{
${ }^{761}$ Louis Chan, "An Overview of Central Asian Markets on the Silk Road Economic Belt," Hong Kong Trade Development Council, November 15, 2015, http://hkmb.hktdc.com/en/1X0A4C4W/hktdcresearch/An-Overview-of-Central-Asian-Markets-on-the-Silk-Road-Economic-Belt

762 Thomas Luce, "Kazakhstan's Reform and Development Play," Silk Road Reporters, November 15, 2014, http://www.silkroadreporters.com/2014/11/15/kazakhstans-reform-development-play/
} 
would also help Kazakhstan modernize its energy sector and help it become an electricity provider to China, as well as to other countries through Chinese territory. This is something that would link sections of the two countries' national grids, and mark an important step towards greater economic integration. The second reason that this deal was important is that the National Bank of Kazakhstan and the People's Bank of China agreed to currency swaps that would pave the way for greater usage of local currencies in BRI projects as well as "promote local currency settlement and enhance both countries' immunity to financial risks and global competitiveness." 763 By reaching this agreement China was also demonstrating its expressed interest in shouldering greater responsibilities in the global financial order, something that was expressed by Xi Jinping during his BRI announcement as well as the vision plan.

On March 24, 2015 Li Keqiang and Karim Masimov, signed 33 deals worth \$23.6 billion. These deals focused on cooperation on "steel, non-ferrous metals, sheet glass, oil refining, hydropower and automobile." ${ }^{, 764} \mathrm{Li}$ commented that the deals demonstrated the complementarity of the two countries' economies and the success of their bilateral relations. Evidence of this success is illustrated by more than 700 Chinese-funded companies and Sino-Kazakh joint ventures operating in Kazakhstan that have resulted in substantial local employment. ${ }^{765}$ The March deal was supplemented less than a few months later when on

\footnotetext{
${ }^{763}$ Malika Orazgaliyeva, “Kazakhstan, China Ink \$14 Billion in Cooperation Deals,” The Astana Times, December 17, 2014, https://astanatimes.com/2014/12/kazakhstan-china-ink-14-billion-cooperation-deals/

764 “China, Kazakhstan, Sign 33 Deals Worth 23.6 Billion U.S. Dollars,” Xinhuanet, March 23, 2015, http://www.xinhuanet.com/english/2015-03/27/c_134104187.htm

765 “China, Kazakhstan to Bolster Economic, Industrial Capacity, China Daily, May 7, 2015, https://www.chinadaily.com.cn/world/2015xiattendwwii/2015-05/07/content_20650929_2.htm
} 
September 1, 2015, Xi Jinping and Nursultan Nazarbayev signed an additional 25 deals worth $\$ 23$ billion. According to Nazarbayev, these deals would help the Sino-Kazakh economic relationship transition from being purely dominated by raw material exports to value-added products. ${ }^{766}$ In other words, China's investments were helping Kazakhstan's economy diversify by moving up the value-added chain, something that has been recognized by Kazakh leaders as important due to the economy's overreliance on oil exports. In fact, part of the rationale for Nazarbayev's announcement of the Bright Road development initiative was the economic slump that ensued after oil prices collapsed after the 2008 global financial crisis. ${ }^{767}$

The two smaller, and poorest, Central Asian republics, Kyrgyzstan and Tajikistan, have received aid and investment primarily focused on repairing and upgrading roads and railways. ${ }^{768}$ This is aimed at facilitating transit and galvanizing economic activity. Many of these roads and railway projects had been initiated before the announcement of the BRI. However, as indicated above, placing these projects under the rubric of the BRI, has added impetus to their completion. The focus on these republics is directly correlated to their proximity to southern Xinjiang, the most underdeveloped and restive part of the province.

\footnotetext{
766 “Kazakh Leader Says \$23 Billion in Deals Agreed with China,” Reuters, September 1, 2015, https://www.reuters.com/article/kazakhstan-china/kazakh-leader-says-23-billion-in-economic-deals-agreedwith-china-idUSL5N1172H620150901

767 Thomas Luce, “Kazakhstan's Reform and Development Play,” Silk Road Reporters, November 15, 2014, http://www.silkroadreporters.com/2014/11/15/kazakhstans-reform-development-play/

768 Donald Tang, "China's Investment in the Central Asian Republics," The Foreign Military Studies Office, 2015, p. 3-26; http://fmso.leavenworth.army.mil/documents/China/DonaldTang_China_CentralAsianRepublics.pdf
} 
Kyrgyzstan's 2005 and 2010 Tulip Revolutions generated a lot of concerns within China. ${ }^{769}$ Furthermore, Tajikistan's civil war and its long-running political instability, in addition to its border with Afghanistan, has been an ongoing source of concern for China. ${ }^{770}$ Therefore, the economic development of these republics is viewed as an important component of the BRI. Of these two republics, Kyrgyzstan, has a closer economic relationship with China and has received significant FDI from China. Among the main projects that China has invested in Kyrgyzstan has been the repair and modernization of the Bishkek Thermal Power Plant. After Xi Jinping's visit to Kyrgyzstan, in 2013, the two sides agreed to the plant's repair and modernization. Following this agreement, Xinjiang's Tebian Electric Apparatus (TBEA) in a partnership with Kyrgyzstan's Electric Stations JSC, signed a deal worth $\$ 386$ million for the project. The modernization project, completed in $2017,{ }^{771}$ increased the plant's generating capacity to 600 megawatts, although by 2015 , the plant was generating close to a billion kilowatts per hour of electricity in addition to two million gigacalories of heat energy a year. As a result, the plant was providing heating and hot water to $85 \%$ of the Kyrgyz capital by $2015 .{ }^{772}$

\footnotetext{
${ }^{769}$ Alexander Cooley, Great Game, Local Rules: The New Great Power Contest in Central Asia (Oxford: Oxford University Press, 2012), p. 81-83

${ }^{770}$ Fuad ShahBazov, "China's Economic and Military Expansion in Tajikistan," The Diplomat, November 23, 2016, https://thediplomat.com/2016/11/chinas-economic-and-military-expansion-in-tajikistan/

771 "Modernization of Bishkek Thermal Power Plant Completes in Kyrgyzstan," Kabar, August 30, 2017, http://kabar.kg/eng/news/modernization-of-bishkek-thermal-power-plant-completes-in-kyrgyzstan/

${ }^{772}$ Zhuwei Wang, "Securing Energy Flows from Central Asia to China and the Relevance of the Energy Charter Treaty to China," Energy Charter Secretariat, 2015, p. 28-29, https://energycharter.org/fileadmin/DocumentsMedia/Thematic/China_and_the_ECT_2015_en.pdf
} 
China has also launched two oil refineries in Kyrgyzstan since 2013 with the aim of supplying the energy-poor country with oil from the fields it operates in Kazakhstan. This is an important development for Kyrgyzstan which, until the launch of these two refineries, only possessed a single refinery and relied heavily on refined Russian oil and gasoline from its Siberian refineries. ${ }^{773}$ In addition to the refineries, China has helped develop Kyrgyzstan's electricity grid. On August 28, 2015, TBEA completed a 450kilometer power line that would help Kyrgyzstan save millions in transit fees since its electricity would no longer need to pass through Kazakhstan and Uzbekistan. In addition to helping Kyrgyzstan save money, the power line, which cost $\$ 390$ million, would also help the country become increasingly energy independent. ${ }^{774}$

One of China's key transportation infrastructure projects in Kyrgyzstan has been the Alternate North-South Road, towards which the Chinese Eximbank has provided $\$ 400$ million out of the total cost of $\$ 850$ million. Agreement for the project was reached at the $3^{\text {rd }}$ China-Central Asia Cooperation Forum. The road facilitates Kyrgyzstan's linkages to Kazakhstan's and Tajikistan's roadways in order to better integrate truck traffic from these three republics to the CCAWAEC. ${ }^{775}$ In an interesting development, during Foreign

\footnotetext{
${ }^{773}$ See: Alexandros Petersen, "Chinese Refinery in Kyrgyzstan to Reduce Russian Leverage," China in Central Asia, April 13, 2013, http://chinaincentralasia.com/2013/04/03/chinese-refinery-in-kyrgyzstan-toreduce-russian-leverage/; Dinara Taldybayeva, "Prospects for China - Kyrgyzstan Economic Relations in the Framework of the Silk Road Economic Belt Project," Hong Kong Trade Development Council, March 28, 2017, http://china-trade-research.hktdc.com/business-news/article/The-Belt-and-RoadInitiative/Prospects-for-China-Kyrgyzstan-Economic-Relations-in-the-Framework-of-the-Silk-RoadEconomic-Belt-Project/obor/en/1/1X000000/1X0A9JIX.htm

774 “Kyrgyzstan Hails 'Historic' China-Financed Power Line,” The Strait Times, August 28, 2015, http://www.straitstimes.com/asia/kyrgyzstan-hails-historic-china-financed-power-line

775 See: “China Lends $\$ 300$ mn to Build Strategic Road in Kyrgyzstan,” Daily Mail, June 16, 2015, http://www.dailymail.co.uk/wires/afp/article-3126461/China-lends-300-mn-build-strategic-road-
} 
Minister Wang Yi's visit to Kyrgyzstan in 2015, Kyrgyz economic officials suggested that Beijing relocate forty or so manufacturing operations from China to Kyrgyzstan. ${ }^{776}$ Beijing gave its official approval to this request the following year during Minister Yi's return visit to Bishkek. ${ }^{777}$ The agreement aims to reindustrialize Kyrgyzstan which saw many of its factories fall into disrepair after the Soviet collapse. Considering that there will be limitations to the number of Chinese laborers permitted to work in these relocated industries, thus agreement presents a legitimate effort on the part of the PRC to help its neighbor develop. Furthermore, in the context that Chinese officials have preferred to send less efficient industries inland in order to help these provinces develop, it is very clear that Beijing sees value in relocating these industries for the purpose of stabilizing this important neighbor. Though far from exhaustive, this list of investments demonstrates how China has targeted core sectors in Kyrgyzstan that can facilitate transit, domestic energy production, and industrialization. By focusing on these sectors, China is essentially replicating the same development strategies it has pursued domestically when it has sought to bring development to underdeveloped areas.

\footnotetext{
Kyrgyzstan.html; Suyunbek Shamshiev, "Alternative Road North-South in Kyrgyzstan Built on New Technology," 24, May 19, 2017, https://24.kg/english/52135_Alternative_road_North_South_in_Kyrgyzstan_built_on_new_technology/

${ }^{776}$ Ramtanu Maitra, "Kyrgyzstan and Tajikistan: The Crucial Challenge in Central Asian Development," Executive Intelligence Review, February 3, 2017, p. 26, https://www.larouchepub.com/eiw/public/2017/eirv44n05-20170203/24-31_4405.pdf

777 Cholpon Orozobekova, "China Relocating Heavy Enterprises to Kyrgyzstan,” Eurasia Daily Monitor, The Jamestown Foundation, June 24, 2016, https://jamestown.org/program/china-relocating-heavyenterprises-to-kyrgyzstan/
} 
Tajikistan, as the poorest of the Central Asian republics, has also received Chinese aid and FDI focused on industries that parallel those of Kyrgyzstan. In other words, the aims are the same. For example, Tajikistan has also received a number of relocated Chinese industries, bringing with them FDI and the creation of new jobs. ${ }^{778}$ Additionally, as in the case of Kyrgyzstan, TBEA in a partnership with Tajikistan's Barqi Tojik, signed a deal worth $\$ 349$ million in order to upgrade the Dushanbe-2 Combined Heat and Power Plant (CHP) from its initial 100-megawatt generation, to 400 megawatts. The upgrade was completed 17 months later, ahead of schedule. Tajik President Emomali Rahmon (1992present), hailed the project as an important first step in realizing Tajikistan's energy independence. ${ }^{779}$ Projects like these are critical for Tajikistan which has struggled to foster economic development after a long civil war in the 1990. Electricity production is important for the country since even though it possesses the eighth largest hydropower potential the world, ${ }^{780}$ it struggles to provide generate enough electricity to run its aluminum plants at full capacity. Considering that aluminum is a major source of the country's foreign exchange, this is a serious development. ${ }^{781}$

\footnotetext{
${ }^{778}$ Dirk van der Kley, "China Shifts Polluting Cement to Tajikistan," China Dialogue, August 8, 2016, https://www.chinadialogue.net/article/show/single/en/9174-China-shifts-polluting-cement-to-Tajikistan 779 "Commissioning of Dushanbe-2 Combined Heat and Power Plant," President of the Republic of Tajikistan, August 12, 2016, http://www.president.tj/en/node/13645

780 “Tajikistan,” International Hydropower Association, 2015, https://www.hydropower.org/countryprofiles/tajikistan

781 "1.8bn Tajik Aluminum Plan Deal highlights China's Growing Influence in Central Asia," Eurasian Business Briefing, November 22, 2017, http://www.eurasianbusinessbriefing.com/1-5bn-tajik-aluminiumplant-deal-highlights-chinas-growing-influence-central-asia/
} 
This is part of the reason why China's investment ventures in the Tajikistan are a boon to the country's economy. On November 2017, Yunnan Construction and Investment Holding Group, in a partnership with Tajikistan's Aluminum Company (TALCO) valued at $\$ 1.8$ billion, agreed to build a new aluminum plant that was more energy efficient. ${ }^{782}$ In an effort to improve Tajikistan's energy generation, Shandong's Dong Ying Heli Investment and Development Company Limited was given a contract to build an oil refinery in Tajikistan's Danghara Free Economic Zone in 2014. The project is designed in two stages with the first costing $\$ 160$ million and the second $\$ 300$ million. Oil to supply the refinery was secured from Russia as well as Iran. ${ }^{783}$ Although the first stage was meant to become operational by 2015 , issues with construction as well as the supply of oil have delayed the beginning of operations to $2019 .{ }^{784}$ Investing in Tajikistan's hydropower potential would appear to be a logical sector for China to invest in considering its vast expertise in dam construction. However, the geopolitics involved in dam construction in the region has been a deterrent for China. Nevertheless, China, through the AIIB, has resorted to modernizing Tajikistan's existing dams. On June 15, 2017, the AIIB in cooperation with the World Bank and other financial institutions, approved a $\$ 350$ million rehabilitation project for the Nurek hydropower plant. The plant, which was commissioned in 1972 with a capacity to generate 3,000 megawatts, can provide $70 \%$ of Tajikistan's

\footnotetext{
${ }^{782}$ Ibid.

${ }^{783}$ Sara Rajabova, "China to Construct Oil Refinery in Tajikistan,” Azernews, March 10, 2015, https://www.azernews.az/region/78842.html

784 “Tajikistan Seeks to Commission $1^{\text {st }}$ Stage in Danghara Oil Refinery in 2019, Trend News Agency, January 22, 2018, https://en.trend.az/casia/tajikistan/2850879.html
} 
annual energy requirements. However, as a result of inefficiency and ageing, the plant is currently operating at $77 \%$ capacity. This has led to chronic electricity shortages for $70 \%$ of the population during the winter months. The completion of this project is slated for $2023 .^{785}$

One of the BRI projects that has the potential for bringing Tajikistan, as well as Kyrgyzstan, energy security, is the Line D section of the China-Central Asia gas pipeline. Rather than follow the same parallel course as the three existing lines, the new route would connect Turkmenistan's Galkynysh field to Kashgar, in southern Xinjiang, after traversing Uzbekistan, Tajikistan, and Kyrgyzstan. ${ }^{786}$ The agreement for Line D was made in 2013 during Xi Jinping's tour of Central Asia, and by the following year, Uzbekistan's and Tajikistan's national gas operators signed agreements with CNPC for joint operation of the proposed pipeline. Work on the pipeline began that same year, and although reports of cancellation surfaced in the summer of $2017,{ }^{787}$ by early 2018 reports indicated that participants had resumed construction of the pipeline after resolving undisclosed disagreements. ${ }^{788}$ Line D, which will add up to 30 billion cubic meters of gas to the existing

\footnotetext{
785 “Tajikistan,” Nurek Hydropower Rehabilitation Project, Phase I," Asian Infrastructure Investment Bank, June 15, 2017, https://www.aiib.org/en/projects/approved/2017/nurek-hydropower-rehabilitationproject.html

786 "Flow of Natural Gas from Central Asia," China National Petroleum Corporation, 2016, http://www.cnpc.com.cn/en/FlowofnaturalgasfromCentralAsia/FlowofnaturalgasfromCentralAsia2.shtml

787 See: "As the Construction of Turkmenistan's Largest Pipeline is Halted, the Country's Crisis Worsens," Asia News, March 13, 2017, http://m.asianews.it/news-en/As-the-construction-ofTurkmenistan\%E2\%80\%99s-largest-pipeline-is-halted,-the-country\%E2\%80\%99s-crisis-worsens40181.html; Casey Michel, "China's Canceled Pipeline Puts Central Asia Back at Integration Drawing Board," World Politics Review, April 19, 2017, https://www.worldpoliticsreview.com/articles/21868/chinas-canceled-pipeline-puts-central-asia-back-at-the-integration-drawing-board

${ }^{788}$ See: "Work Resumes on Troubled Turkmenistan-China Pipeline," Oil Price, February 4, 2018, https://oilprice.com/Geopolitics/Asia/Work-Resumes-On-Troubled-Turkmenistan-China-Pipeline.html;
} 
55 billion cubic feet capacity of the other three lines, is slated for completion in 2020 . The CNPC has agreed to invest $\$ 800$ million in the 200-kilometer Uzbek portion of the line, and as much as $\$ 3.7$ billion has been slated for the more technically complex 410-kilometer Tajik section. ${ }^{789}$ In a related project, a fiberoptic communications cable that is needed for the operation and management of the pipeline, has commercial provisions that would allows Tajikistan buy data at a low cost. ${ }^{790}$ Since internet penetration remains exceedingly low in Tajikistan, in addition to being costly, this would be a boon to Tajik households and commercial firms. ${ }^{791}$

This pipeline allows the poorest two Central Asian republics to profit from transit revenue as well as secure an alternate supply of energy, something that is a welcome development since Kyrgyzstan and Tajikistan have been reliant on Russia energy, which in the past, Russia has used as leverage in negotiations. Furthermore, as the two Central Asian countries most reliant on remittances from Russia, ${ }^{792}$ the ability to begin generating domestic economic development through increased connectivity, resource extraction, transit fees, and industrialization, allows these countries to have greater political and

\footnotetext{
"Tajik Energy Minister Confirms Work resumed on Central Asia-China Gas Pipeline," bne IntelliNews, February 2, 2018, http://www.intellinews.com/tajik-energy-minister-confirms-work-resumed-on-centralasia-china-gas-pipeline-136162/

789 “Tajik Energy Minister Confirms Work resumed on Central Asia-China Gas Pipeline," bne IntelliNews, February 2, 2018, http://www.intellinews.com/tajik-energy-minister-confirms-work-resumed-on-centralasia-china-gas-pipeline-136162/

790 “Work Resumes on Troubled Turkmenistan-China Pipeline," Oil Price, February 4, 2018, https://oilprice.com/Geopolitics/Asia/Work-Resumes-On-Troubled-Turkmenistan-China-Pipeline.html

791 “Tajikistan," OpenNet Initiative, December 1, 2010, https://opennet.net/research/profiles/tajikistan

792 “TCA: Kyrgyzstan, Tajikistan Greatly Depend on Migrant Labor,” Kabar, May 28, 2017, http://kabar.kg/eng/news/tca-kyrgyzstan-tajikistan-greatly-dependent-on-migrant-labor/
} 
economic diversification. As the only countries that did not, or perhaps could not, develop a multi-vector foreign policy in the post-Soviet period, the BRI is creating the foundations for them to do so.

China's initial investments in Uzbekistan after announcing the BRI focused on resource extraction, particularly oil, gas, and uranium. To that end, Xi Jinping and Islam Karimov signed a deal worth $\$ 13$ billion to focus on cooperation in these sectors. Karimov commented that throughout the years of Uzbekistan's independent development, "China has never linked the provision and expansion of multifaceted bilateral co-operation with any political or other conditions," indicating how China's policy of non-interference has facilitated its relations with the reclusive country. ${ }^{793}$ Moreover, in an indication of China's shift towards better connectivity and fostering local development, it signed one of the most crucial projects with Uzbekistan in 2013: the Angren-Pap railway. The line creates a direct domestic route from the Uzbek capital, Tashkent, to the Fergana Valley region, its most densely populated and restive region. The Fergana valley is the site of the 2005 Andijan Massacre, and this railway essentially facilitates Uzbek central authorities to exercise greater control of the region. Although the line is only 123 kilometers long, the project required the construction of a tunnel through the Qamchiq Pass, which increased its technical complexity. The resulting Qamchiq Tunnel, built by the China Railway Tunnel Group and partially funded by a $\$ 350$ million China Eximbank loan, runs through 19.1

\footnotetext{
793 “Xi Jinping Signs Deals Worth US\$15b in Uzbekistan," South China Morning Post, September 9, 2013,
} http://www.scmp.com/news/china/article/1307127/china-uzbekistan-sign-agreements-worth-us15-billion 
kilometers of the line, making it the longest in Central Asia. ${ }^{794}$ The line was inaugurated in a ceremony by Xi and Karimov on June 22, 2016. At the ceremony, Xi stated that China was willing to "strengthen cooperation with Uzbekistan to constantly improve the connectivity of the infrastructure in the region, thus creating more favorable environment for the development of our two countries and bringing greater benefits to both peoples." Karimov, on the other hand, highlighted the importance of the railway to the economic and social development of Uzbekistan. ${ }^{795}$

A visit by Karimov's successor, Shavkat Mirziyoyev (2016-present), to Beijing on May 12, 2017, led to the signing of 105 deals worth $\$ 22$ billion. Marking the $25^{\text {th }}$ anniversary of the establishment of Sino-Uzbek diplomatic relations between, the deals not only focused on traditional investment on resource extraction, but also on the modernization of Uzbekistan's industrial base and the improvement of transportation connectivity. Some of the deals are crucial to Uzbekistan's economic development. For example, one of the agreements paves the way for China to modernize 299 pumping stations. This project would make the water pumps more efficient in usage of water resources as well as electricity consumption. ${ }^{796}$ The relevance of this modernization is

\footnotetext{
${ }^{794}$ See: Mirzohid Rahimov, "The Pap-Angren Railway and its Geoeconomic Implications for Central Asia," The Central Asia-Caucasus Analyst, April 19, 2016, https://www.cacianalyst.org/publications/analytical-articles/item/13354-the-pap-angren-railway-and-itsgeoeconomic-implications-for-central-asia.html; Ramtanu Maitra, "The Multiple Dimensions of China's 'One Belt One Road' in Uzbekistan," The Schiller Institute, February 2017, http://www.schillerinstitute.org/economy/phys_econ/2016/1227-obor-uzbek/ou.html\#footnote-138676-4

795 "Chinese, Uzbek Leader Hail Inauguration of Central Asia's Longest Railway Tunnel," Xinhuanet, June 23, 2016, http://www.xinhuanet.com/english/2016-06/23/c_135458470.htm

796 “Uzbekistan and China Sign Agreements Worth \$22 Billion: 105 Documents on Gas, Energy Saving, Agriculture," Ferghana News, May 15, 2017, http://enews.fergananews.com/news.php?id=3341\&mode=snews
} 
linked with the country's important cotton sector. These pumping stations regularly suffer from electricity shortages, despite the abundant hydrocarbon resources in Uzbekistan. This creates interruptions in irrigation, which can be costly to the domestic economy since this sector employs roughly $30 \%$ of the population. Furthermore, the inefficient usage of water in this sector has been the main culprit behind water shortages in the country, but more importantly, the desiccation of the Aral Sea. ${ }^{797}$ In other words, the modernization of these water pumps is a first step in modernizing a crucial economic sector in Uzbekistan as well as addressing a serious water scarcity problem.

The deal also includes investment in Uzbekistan's agricultural sector, something that is attributed to China's growing demand for textiles and agricultural products. However, this meeting also led to the signing of important infrastructure projects. According to Khusniddin Khosilov, the chief engineer at Uzbekistan Temir Yollari, the country's national railway corporation, Mirziyiyev's visit also resulted in agreements for China to build a road tunnel through the Qamchiq Pass under the completed railway tunnel. He added that a feasibility study for the proposed Qamchiq-2 tunnel was underway. In addition to this project, there was an agreement for China to build a ring road around Tashkent in order to facilitate traffic in the city and improve the economic environment for

\footnotetext{
797 See: Iskandar Abdullaev, Mark Giordano, and Aziz Rasulov, "Cotton in Uzbekistan: Water and Welfare,” Center for Development Research University of Bonn, p. 112-128, https://www.zef.de/uploads/tx_zefportal/Publications/83a8_Abdullaev\%20100807.pdf; Nodir Djanibekov, Inna Rudenko, John P. A. Lamers, and Ihtiyor Bobojonov, "Pros and Cons of Cotton Production in Uzbekistan," in Food Policy for Development Countries: Food Production and Supply Policies, ed. Per Pinstrup-Andersen and Derrill D. Watson II (Ithaca: Cornell University Press, 2010), p. 1-13
} 
investors. ${ }^{798}$ The proposed Qamchiq-2 tunnel is particularly relevant in the context of Mirziyoyev's efforts to improve Uzbekistan's relations with its Central Asian neighbors which has led to progress in regional connectivity. ${ }^{799}$ For example, on October 30, 2017, China was able test a crucial road transport route between Kashgar, Irkeshtam and Osh in Kyrgyzstan, on to Andijan and Tashkent in Uzbekistan. ${ }^{800}$ On February 25, 2018, the route was officially opened for traffic, effectively shortening the transport time between China and Uzbekistan from 8 days to 2 days. According to the Uzbek government, the route will result in the reduction of transport costs and create more than a million jobs in connected industries. The route will extend to Dushanbe, Tajikistan by April 2018, thus opening up trade activity to southern Xinjiang and Central Asia's least developed republics. ${ }^{801}$ Completion of the Qamchik-2 tunnel would allow for even faster travel times and fewer disruptions due to mudslides and snow during winter months.

As in the case with Kazakhstan, China has invested in over 700 firms in Uzbekistan, thus creating job opportunities and helping the country develop. ${ }^{802}$ This indicates that

\footnotetext{
798 "China to Help Build a Second Tunnel at Kamchik Pass," The Tashkent Times, May 16, 2017, http://tashkenttimes.uz/economy/930-china-to-help-build-second-tunnel-at-kamchik-pass

799 Kenneth Rapoza, "Eurasia's Latest Economic Reboot Can Be Found in Uzbekistan," Forbes, September 14, 2017, https://www.forbes.com/sites/kenrapoza/2017/09/14/eurasias-new-perestroika-uzbekistan-silkroad-china/\#8a6cdf66f25c

800 "China-Kyrgyzstan-Uzbekistan Highway to Open to Traffic on Feb." Yidaiyilu, February 24, 2018, https://eng.yidaiyilu.gov.cn/qwyw/rdxw/48721.htm

801 "China-Kyrgyzstan-Uzbekistan Highway Opens to Traffic," Yidaiyilu, February 27, 2018, https://eng.yidaiyilu.gov.cn/qwyw/rdxw/49135.htm

802 "Uzbekistan and China Sign Agreements Worth \$22 Billion: 105 Documents on Gas, Energy Saving, Agriculture," Ferghana News, May 15, 2017, http://enews.fergananews.com/news.php?id=3341\&mode=snews
} 
China's investment in Uzbekistan, has begun to focus on modernizing Uzbekistan's industrial base as well as increase its connectivity. ${ }^{803}$ Therefore, even though resource extraction continues to be an important component of the Sino-Uzbek economic relationship, there has been significant diversification since the announcement of the BRI. In fact, the development of Uzbekistan, as well as Kyrgyzstan and Tajikistan, would pave the way for greater economic activity in southern Xinjiang, as a result of the newly established transport route. Furthermore, it would provide these countries more direct access to China's maritime ports in the same way that Kazakhstan has. ${ }^{804}$

China's investments in Turkmenistan continue to be dominated by resource extraction, particularly of the country's abundant natural gas reserves. Although China has invested in Turkmenistan's road infrastructure, this investment occurred before the BRI. Furthermore, Turkmenistan's closed economic system has made it difficult for China to penetrate other sectors beyond energy. Thus, as indicated above and in previous chapters, Chinese investment has been directed at exploiting and modernizing Turkmenistan's natural gas fields and refineries. Additionally, investment has gone to construct and operate the three existing lines in the Central Asia-China gas pipelines, as well as the one currently under development. Furthermore, the CNPC, as one of the operators of the world's second largest natural gas field, Galkynysh, Turkmenistan provides China with a vast source to

\footnotetext{
${ }^{803}$ Ramtanu Maitra, The Multiple Dimensions of China's 'One Belt One Road' in Uzbekistan,” The Schiller Institute, February 2017, http://www.schillerinstitute.org/economy/phys_econ/2016/1227-oboruzbek/ou.html\#footnote-138676-4

804 "Kazakhstan Gets Sea Access Using Chinese Logistics Centres," The Astana Times, August 2017, 2017, https://astanatimes.com/2017/08/kazakhstan-gets-sea-access-using-chinese-logistics-centres/
} 
feed its growing economy. This is important since the transition in China's domestic economy away from coal towards cleaner sources of fuel have led to an increase in natural gas demand ${ }^{805}$ Coupled with China's low domestic production capacity, Turkmenistan's role will only increase in the coming years. Ashgabat already supplies $50 \%$ of China's natural gas imports, as a result, it is China's most important natural gas energy partner. Consequently, Turkmenistan's role in the BRI continues to be dominated by its position as a guarantor of China's energy security. However, Turkmenistan also serves as the gateway to Southwest Asia, especially Iran. ${ }^{806}$

Iran's place in the China-Central Asia-West Asia Economic Corridor is important as it not only serves as a source of energy and is a substantial consumer of Chinese goods, it is also a gateway to the Persian Gulf, Southwest Asia, and Europe. Despite its importance to the BRI, however, international sanctions were a major obstacle to China's goal of integrating Iran into the CCAWAEC. That changed on January 16, 2016 when the Joint Comprehensive Plan of Action (JCPOA), was implemented by the P5+1 (China, France, Germany, Russia, the United Kingdom, and the United States). ${ }^{807}$ The plan removed a number of sanctions on Iran in exchange for accepting limitations on its nuclear program

\footnotetext{
${ }^{805}$ Ryan McKinley, "Market Capture: China's Energy Relationship with Turkmenistan," Enerpo Journal, October 31, 2014, https://enerpojournal.com/2014/10/31/market-capture-chinas-energy-relationship-withturkmenistan/

${ }^{806}$ See: Qaya Mammadov, “Turkmenistan Positions Itself as Eurasian Natural Gas Power,” Oil \& Gas Journal, December 7, 2015, https://www.ogj.com/articles/print/volume-113/issue12/transportation/turkmenistan-positions-itself-as-eurasian-natural-gas-power.html; "Ruzlan Izimov: China and Turkmenistan - a Regional Dimension," Central Asia Bureau for Analytical Reporting, August 29, 2016, http://cabar.asia/en/ruslan-izimov-china-and-turkmenistan-a-regional-dimension/

807 “Joint Comprehensive Plan of Action," U.S. Department of State, https://www.state.gov/e/eb/tfs/spi/iran/jcpoa/
} 
and submitting to inspections by the International Atomic Energy Agency. This led to a flurry of international corporations signing memoranda of understandings with Iran, however, it was China that emerged as the main player in this rush. ${ }^{808}$ Immediately after the JCPOA was implemented, Xi Jinping resolved to visit Iran.

Prior to his visit, however, Xi Jinping published an editorial outlining his vision for future Sino-Iranian relations. Unsurprisingly, Xi alluded to the 2,000 years of Sino-Persian relations, highlighting Persian poet Saadi Shirazi's visit to Kashgar during the $13^{\text {th }}$ century and Ming Dynasty Admiral Zheng He's visit to southern Persia during the $15^{\text {th }}$ century. Xi remarked how the regular trade interactions between the two civilizations made it seemed as through the two countries were "just a camel-ride or a boat trip away." ${ }^{809}$ In the contemporary period, Xi indicated that China and Iran had maintained friendly exchanges throughout the 45 years of diplomatic relations, and that this relationship embodied the Silk Road spirit of peace, cooperation, openness, inclusiveness, mutual learning and mutual benefit. By alluding to this history, Xi Jinping, as he had done several times before (as have other Chinese leaders), was establishing the normative foundation for Sino-Iranian cooperation in the BRI as well as establishing the historicity of China's engagement with major civilizations along the historical Silk Road.

\footnotetext{
${ }^{808}$ Reese Erlich," As US Sanctions Keep Western Businesses out of Iran, China Seizes the Opportunity," PRI, December 17, 2017, https://www.pri.org/stories/2017-12-28/us-sanctions-keep-western-businessesout-iran-china-seizes-opportunity

${ }^{809}$ Jinping Xi, "Work Together for a Bright Future of China-Iran Relations: President Xi," The Iran Project, January 22, 2016, https://theiranproject.com/blog/2016/01/22/work-together-for-a-bright-future-ofchina-iran-relations-president-xi-2/
} 
After establishing this normative foundation, Xi Jinping indicated that the Chinese thirteenth five-year plan and the Iranian sixth five-year plan were complementary development strategies. As a result, he outlined areas of possible cooperation between the two countries under the BRI framework. One of the main areas outlined by $\mathrm{Xi}$ was to “deepen cooperation with Iran on building roads, railway, sea routes and the Internet, and facilitating East-West connectivity in Asia." 810 Thus, as has been the theme since the announcement of the BRI, Xi Jinping was aiming to diversify China's investments in participant countries beyond resource extraction. Iran would continue to be a major source of oil for China, that much is certain. However, after the JCPOA, Iran's geopolitical and economic potential could really begin to emerge, especially with continued Chinese support. Iran is central to any east-west corridors that China aims to establish through overland routes, hence its important position in the CCAWAEC. In fact, in 2015, Dr. Zhao Baige, Deputy Director of the PRC Foreign Affairs Committee, explicitly stated that Iran was one of the most crucial countries along the BRI. ${ }^{811}$ Iran is also perceived as playing an important role in the stability of the region, especially Afghanistan which remains a major concern for China. This is one of the reasons for China's continued efforts to grant Iran full membership in the SCO. ${ }^{812}$

\footnotetext{
${ }^{810}$ Ibid.

${ }^{811}$ Michael Schwartz, "The Development of the Sino-Iranian Limited Partnership: China’s \$600-Billion Proposition," Middle East Economy 6(9), 2016, p. 6, https://dayan.org/content/development-sino-iranianlimited-partnership-china\%E2\%80\%99s-600-billion-proposition

812 "President in the Meeting of High-Ranking Delegations of Iran and China: A New Chapter in TehranBeijing Ties Started/25-Year Comprehensive, Executive Document Soon," President of the Islamic Republic of Iran, January 23, 2016, http://president.ir/en/91443
} 
On January 22, 2016, Xi Jinping became the first world leader to visit Iran after the JCPOA came into force. ${ }^{813}$ Upon his visit, $\mathrm{Xi}$ and his Iranian counterpart, Hassan Rouhani (2013-present), agreed to expand bilateral trade to $\$ 600$ billion over the next decade. Expanding this economic relationship is considered crucial for Xi Jinping who recognizes the importance of Iran. Xinyu Mei, a researcher at China's Ministry of Commerce, encapsulates this sentiment commenting that Iran is one of the most important players in the Middle East, making it a vital partner for China's strategies in Eurasia and Africa. Mei added that in addition to Iran's vast energy resources, the country's large population was an attractive market for Chinese businesses, indicating the importance of a market that remains largely untapped by foreign investors. ${ }^{814}$

During his visit, $\mathrm{Xi}$ and Rouhani signed 17 cooperation agreements aimed at expanding trade, improving Iran's infrastructure, as well as advancing the development of the BRI. ${ }^{815}$ In addition to discussing economic ties, the two leaders spoke about security in the region, expressing their support for countries plagued with terrorism and vowing to combat regional terrorism and extremism. ${ }^{816}$ This is something that is important for China,

\footnotetext{
${ }^{813}$ Zhou Xin, “China, Iran Opens 'New Chapter' in Bilateral Ties as President Xi Jinping Visits Tehran as Peacemaker, Power Broker and Major Buyer of Oil,” South China Morning Post, January 24, 2016, http://www.scmp.com/news/china/diplomacy-defence/article/1904328/china-iran-opens-new-chapterbilateral-ties-president

814 Ibid.

${ }^{815}$ See: "Iran and China Sign 17 Agreements at Meeting of Rouhani and Xi in Tehran," Agencia EFE, January 23, 2016, https://www.efe.com/efe/english/business/iran-and-china-sign-17-agreements-atmeeting-of-rouhani-xi-in-tehran/50000265-2819088; "Iran, China, Sign 17 Cooperation Agreements," Islamic Republic News Agency, January 23, 2016, http://www.irna.ir/en/News/81931797

816 “Iran, China Plan for 25-Year Strategic Partnership,” Iran Daily, January 23, 2016, http://www.irandaily.com/News/135531.html
} 
domestically and internationally. Domestically, it provides Iranian support against East Turkestan groups operating in Syria and Iraq, thus limiting these group's activities in the region and lowering the possibility that they can enter Xinjiang through Afghanistan. Internationally, Iranian cooperation helps improve the security along the CCAWAEC. Rouhani also added that "countries' national borders should be respected, and any country's future should be left for the people of that country to decide for." ${ }^{817}$ Although this is an explicit critique of Western, as well as Saudi, intervention in the many conflicts plaguing Southwest Asia, it shares normative parallels with China's non-interference rhetoric.

Beyond signing the 17 agreements, $\mathrm{Xi}$ and Rouhani also approved a 25-year strategic partnership. This partnership presented a blueprint for Sino-Iranian cooperation in the post-sanctions era. The agreement included provisions for closer political, economic, and cultural cooperation, as well as support for key normative points that have been raised by China and Iran for decades. Beyond the aforementioned support for national sovereignty and territorial integrity, the agreement affirmed support for the multi-polarization of the world order and an increased role for Iran in regional and international affairs. The agreement also recognized the importance of respecting the will of countries and peoples that pursued political and development paths that conformed to their national conditions. Finally, the agreement recognized Iran's contribution to fighting the three evils as well as

\footnotetext{
817 "President in the Meeting of high-Ranking Delegations of Iran and China: A New Chapter in TehranBeijing Ties Started/25-Yeah Comprehensive, Executive Document Soon," President of the Islamic Republic of Iran, January 23, 2016, http://president.ir/en/91443
} 
its role in establishing peace and stability in Southwest Asia. ${ }^{818}$ In essence, the strategic partnership not only demonstrated Chinese rhetorical consistency, but also demonstrated significant overlap between the two country's normative foundations.

Iran's Supreme Leader, Ayatollah Khamenei, welcomed the partnership. He added that China was a trustworthy country and that the "Islamic Republic will not forget Chinese cooperation during the sanctions era." Khamenei also positioned Iran as a reliable energy partner for China, indicating that Iran was the "only state in the region in the field of energy that can be trusted because it is not under influence of any non-Iranian element," unlike some of the other states in the region. ${ }^{819} \mathrm{Xi}$ stated that China had stood on the side of Iran during the sanctions era, and was ready to expand cooperation in the post-sanctions era. ${ }^{820}$ Thus, Xi Jinping’s visit to Iran helped cement the Sino-Iranian bilateral relationship and set the stage for Iran to play its pivotal role in China's BRI.

As part of its efforts to increase trade with Iran, within a month of Xi Jinping's visit to the country, China initiated railway exports to Iran. On February 15, 2016, a train from Yiwu, an inland city in the coastal province of Zhejiang, arrived in Tehran carrying 32 containers, marking the first arrival of a Chinese train in Iran. ${ }^{821}$ Trip was made possible

\footnotetext{
818 "Full Text of Joint Statement on Comprehensive Strategic Partnership Between I.R. Iran, P.R. China," President of the Islamic Republic of Iran, January 23, 2016, http://www.president.ir/en/91435

819 “Iran, China Plan for 25-Year Strategic Partnership,” Iran Daily, January 23, 2016, http://www.irandaily.com/News/135531.html

${ }^{820}$ Ibid.

821 "First Freight Train from China Arrives in Iran in 'Silk Road' Boost," Reuters, February 16, 2016, https://www.reuters.com/article/us-china-iran-railway/first-freight-train-from-china-arrives-in-iran-in-silkroad-boost-media-idUSKCNOVP0W8
} 
due to the completion of the Kazakhstan-Turkmenistan-Iran railway which had been inaugurated in 2014. This line links the three countries by connecting the Kazakh city of Ozam, to Berekt and Etrek in Turkmenistan, and finally, to Gorgan in Iran, ${ }^{822}$ thus making it possible for Chinese freight trains to connect at the Sino-Kazakh border with Kazakh's national railway system and then connect to the new line. This trek has a length of 10,399 kilometers, yet it still arrived in Tehran in 14 days, making it 30 days shorter than the maritime route. ${ }^{823}$ Since the first train's arrival, several Chinese provinces and firms exporting mechanical equipment and automobile accessories have used the route. ${ }^{824}$ In fact, this route has resulted in an agreement between Iran and Yinchuan, the capital of Ningxia Hui Autonomous Region and one of the least developed province in China, to establish regular freight train service to Tehran. According to Liang Hua, CEO of the YinchuanTehran freight project, the route is expected to greatly lower delivery costs to Central Asia and Southwest Asia. ${ }^{825}$

\footnotetext{
822 Azamat Kaiyr and Danna Bupezhanova, "Nazarbayev Helps Launch Last Section of KazakhstanTurkmenistan-Iran Railway," The Astana Times, December 4, 2014, https://astanatimes.com/2014/12/nazarbayev-helps-launch-last-section-kazakhstan-turkmenistan-iranrailway/

823 "First Freight Train from China Arrives in Iran in 'Silk Road' Boost," Reuters, February 16, 2016, https://www.reuters.com/article/us-china-iran-railway/first-freight-train-from-china-arrives-in-iran-in-silkroad-boost-media-idUSKCNOVPOW8

${ }^{824}$ See: "China Freight Train Arrives in Tehran, Six More Planed by Yearend," Financial Tribune, October 2, 2017, https://financialtribune.com/articles/economy-domestic-economy/73300/china-freight-trainarrives-in-tehran-six-more-planned-by; " $3^{\text {rd }}$ Freight Train from China to Arrive in Tehran Within Days," Mehr News Agency, January 6, 2018, https://en.mehrnews.com/news/130965/3rd-freight-train-from-Chinato-arrive-in-Tehran-within-days

${ }^{825}$ See: "Cargo Train Services Launched Between Yinchuan, Tehran," China Daily, September 6, 2017, http://www.chinadaily.com.cn/business/2017-09/06/content_31626069.htm; "China Agrees to Dispatch Two Freight Trains to Iran Every Month," Iran Daily, October 2, 2017, http://www.irandaily.com/News/201621.html
} 
However, this is not the extent of China's goal for Iran's railway sector. Iran's national railway system is already 85 years old and in need of modernization if it is to be effectively linked to the CCAWAEC ${ }^{826}$ On July 26, 2017, China's Eximbank and Iran's Bank of Industry and Mine signed a contract to finance a $\$ 1.5$ billion project that will bring electrification to the Tehran-Mashhad railway. The China National Machinery Import and Export Corporation will be carrying out the project with Iran's MAPNA Group being the main contractor. This project not only increases the speed of the trains operating in the line but is also considered an important step in establishing a shorter and faster line between western China and Iran ${ }^{827}$ The new proposed line would begin at the Horgos landport and head to Almaty, Kazakhstan, located in the south of the country. From there, it would head to Arys, another Kazakh town near the border with Uzbekistan. After Arys, the train would go through Tashkent, Samarkand, and Bukhara in Uzbekistan, some of the most historic Silk Road cities, before heading to Bayramaly in Turkmenistan. After Bayramaly, the train would enter Iran's northeast border and arrive in Mashhad, from where the train would head towards its destination in Tehran. ${ }^{828}$ Another possible version of this line would link Kashgar to Iran through the proposed China-Kyrgyz-Uzbek railway. However, negotiations would need to be concluded before turning this project into a reality.

\footnotetext{
${ }^{826}$ Najmeh Bozorgmehr, "First Freight Trains from China Arrive in Tehran," Financial Times, May 9, 2016, https://www.ft.com/content/e964a78e-0bd8-11e6-9456-444ab5211a2f

827 “Tehran-Mashhad Railway Project Gets Off the Ground," Financial Tribune, December 20, 2017, https://financialtribune.com/articles/domestic-economy/78248/tehran-mashhad-railroad-project-gets-offthe-ground

828 "The Railway to Iran," South China Morning Post, http://multimedia.scmp.com/news/china/article/OneBelt-One-Road/iran.html
} 
Nevertheless, the improvement in Uzbek-Kyrgyz relations after Mirziyoyev taking office in 2016, have raised hopes that this long-postponed project would see fruition. Negotiations are expected to take place mid-2018. ${ }^{829}$

Iranian leaders hope that the modernization of the railways system, in addition to China's BRI, would make the country an important hub for east-west trade. As Rouhani commented during Xi's visit: "geographically, Iran has got the capacity to become a hub for China's economic activities in the Middle East and Central Asia and Caucasus." Furthermore, Iran's ability to connect China with these sub-regions also makes it possible to link China to Europe through a southern corridor, thus providing an alternative to the NELB and integrating a greater number of countries in the east-west economic corridor. Consequently, just like its relationship with the three larger Central Asian countries, China's investment in Iran since the announcement of the BRI, and especially after the JCPOA, has diversified from its pure focus on the energy sector, to others like transportation, something that it believes will increase connectivity and thus generate greater economic activity.

\section{The China-Pakistan Economic Corridor}

What has now become the China-Pakistan Economic Corridor is predated by numerous efforts by both countries to establish overland linkages since the establishment

\footnotetext{
${ }^{829} \mathrm{Xu} \mathrm{He}$, “China-Kyrgyz-Uzbek Railway to Be Finalized in April," China Daily, January 17, 2018, http://www.chinadaily.com.cn/a/201801/17/WS5a5ee7d1a310e4ebf433e4e7.html

830 "President in the Meeting of High-Ranking Delegations of Iran and China: A New Chapter in TehranBeijing Ties Started/25-Year Comprehensive, Executive Document Soon," President of the Islamic Republic of Iran, January 23, 2016, http://president.ir/en/91443
} 
of diplomatic relations. The Karakorum Highway is a testament to this effort. As indicated in the previous chapter, efforts were made to upgrade the highway as well as develop the port of Gwadar during the GWD strategy and Hu Jintao's efforts to mitigate China's Malacca Dilemma. However, political instability in Pakistan led to the postponement of greater bilateral infrastructure projects. Pakistan's relevance resurfaced as a result of Xi Jinping's efforts reach the two centenary goals. Located south of Xinjiang, Pakistan is perceived as an important contributor to the improvement of economic conditions in the southern part of the province. Although this perspective is not new, Xi Jinping's view that development of China was contingent on the development of its Eurasian neighbors changed China's approach to Pakistan as well as its role in the development and stability of Xinjiang. In other words, beyond serving as a mere gateway to the Indian Ocean, Pakistan's development would also contribute to greater demand for Chinese goods, thus facilitating economic development in southern Xinjiang.

The China-Pakistan Economic Corridor in its current iteration technically predates the announcement of the BRI by a few months. The corridor was proposed during $\mathrm{Li}$ Keqiang's visit to Pakistan on May 23, 2013. During his visit, Li stated that China and Pakistan should "focus on carrying out priority projects in connectivity, energy development and power generation and promoting the building of a China-Pakistan economic corridor," alluding to the chronic power shortages across Pakistan that have devastated local industries and led to higher unemployment rates. ${ }^{831}$ The following year,

\footnotetext{
${ }^{831}$ See: Nick Macfie," China's Li Offers to Help End Pakistan Energy crisis," Reuters, May 22, 2013, https://web.archive.org/web/20131230003027/http://www.reuters.com/article/2013/05/22/us-pakistanchina-idUSBRE94L06G20130522; “Li Keqiang: China-Pakistan Ties 'Unbreakable,' Economic Corridor Planned," Global Times, May 23, 2013,
} 
on his way to the Asia-Pacific Economic Cooperation meeting in Beijing, Pakistani Prime Minister, Nawaz Sharif (2013-2017), met with Li Keqiang and Xi Jinping, securing \$45.6 billion in funding for CPEC projects. From this sum, $\$ 33.8$ billion were allocated to various energy projects and $\$ 11.8$ billion were allocated for infrastructure projects. ${ }^{832}$ During his meeting with Sharif, Li expressed that China and Pakistan were intimate and friendly neighbors and "iron friends." Furthermore, Li stated that the CPEC was a flagship project for the BRI and that the corridor would be of mutual benefit to both sides and lead to winwin results. ${ }^{833}$ The Sharif-Xi meeting shared similar rhetoric, with Xi pointing out that China and Pakistan were iron friends and all-weather partners. Xi also indicated that China would support Pakistan in its development and maintenance of stability, adding that he would pay a visit to Pakistan the following year. ${ }^{834}$

On April 19, 2015, before his official visit to Pakistan, Xi Jinping published an editorial outlining his vision for Sino-Pakistan relations in the context of the CPEC. The article begins with a quote from an Urdu poem stating: "my friend's lovely image dwells in the mirror of my heart; I tilt my head slightly, and here it comes into my sight." ${ }^{835}$

\footnotetext{
https://web.archive.org/web/20140312032536/http://gbtimes.com/china/li-keqiang-china-pakistan-tiesunbreakable-economic-corridor-planned

${ }^{832}$ Brigadier Waseem Ishaque, "China-Pakistan Economic Corridor (CPEC): Prospects, Challenges and way Forward,” NDU Journal 2016, p. 126

833 "Li Keqiang: Building the China-Pakistan Economic Corridor Flagship Project," Ministry of Foreign Affairs of the People's Republic of China, November 8, 2014, http://www.fmprc.gov.cn/mfa_eng/topics_665678/ytjhzzdrsrcldrfzshyjxghd/t1209089.shtml

834 "Xi Jinping Meets with Prime Minister Nawaz Sharif of Pakistan," Ministry of Foreign Affairs of the People's Republic of China, November 8, 2014, http://www.fmprc.gov.cn/mfa_eng/topics_665678/ytjhzzdrsrcldrfzshyjxghd/t1209091.shtml

835 "President Xi's Article Published on Pakistani Paper," China Daily, April 19, 2015, http://www.chinadaily.com.cn/world/2015xivisitpse/2015-04/19/content_20474266.htm
} 
According to Xi, the line reflects how he considers Pakistan a good friend. He reminisced hearing stories during his youth about Pakistan's efforts to develop, and more importantly, Pakistan's support for the PRC's membership in the United Nations Security Council. Despite being his first visit to Pakistan, Xi stated that he felt as if he was going to visit the home of his brother. In essence, $\mathrm{Xi}$ was establishing the closeness and importance of Pakistan to China. Xi also supported Pakistan's national development path, suited to its local conditions, and lauded its contribution to the fight against terrorism and extremism, thus reiterating its push for the plurality of development models and the threat of the three evils to national stability and development.

The article also identified five key areas in which China and Pakistan could more effectively cooperate to make the CPEC successful. These areas focus on the alignment of development strategies to bring benefits to people in both countries, as well as promote economic interdependence. It also recognizes Pakistan's unique position in the BRI, not only being an important component of the Silk Road Economic Belt, but also a crucial part of the $21^{\text {st }}$ Century Maritime Silk Road. Lastly, the article calls for greater security cooperation and people-to-people exchanges, highlighting the important role Pakistan plays in the stability in Xinjiang as well as Afghanistan, in addition to aiding China's efforts to develop ideational power. ${ }^{836}$

A few days later, on April 21, 2015, Xi Jinping made his first official visit to Pakistan and addressed the Pakistani Parliament. As he had in his editorial, Xi referred to

\footnotetext{
${ }^{836}$ Ibid.
} 
the closeness of Sino-Pakistan relations, adding that even though this was his first visit to the country, "meeting a good friend for the first time is like having a reunion with an old friend." ${ }^{837}$ Furthermore, as in numerous forums supporting the BRI, Xi alluded to the historical ties between the peoples of China and modern day Pakistan as a result of the Silk Road. Xi also reiterated his support for national development strategies informed by local conditions, as well as China's commitment to non-interference, thus establishing the normative foundation for the CPEC. Additionally, Xi stated that both countries were pursing the rejuvenation of their respective nations and that cooperation was the path to reach this goal. Consequently, he called for deeper cooperation while upholding sovereignty, territorial integrity, and national dignity. Xi stated that helping Pakistan develop was akin to China developing itself, highlighting the importance of codevelopment for China's BRI. He added to that in order to strengthen their relationship, the two countries should enhance people-to-people and cultural exchanges. Moreover, Xi called for greater regional and international security cooperation, while recognizing Pakistan's contribution to the stability of China's western frontier; something that $\mathrm{Xi}$ contended China "would never forget." 838

The CPEC revolves around dozens of projects that, according to Xi Jinping's blueprint, pivot around the port of Gwadar, energy, infrastructure, and industrial

\footnotetext{
837 "Building a China-Pakistan Community of Shared Destiny to Pursue Closer Win-Win Cooperation," Ministry of Foreign Affairs of the People's Republic of China, April 21, 2015, http://www.fmprc.gov.cn/mfa_eng/wjdt_665385/zyjh_665391/t1257158.shtml

${ }^{838}$ Ibid
} 
cooperation. ${ }^{839}$ This involves investment in electricity production, the construction of roads and railways, and the development of industrial parks in Pakistan. In essence, much like the aforementioned corridors, the CPEC aims to increase connectivity in addition to helping generate local economic activity. Successfully doing this would facilitate the development of western China, particularly southern Xinjiang, and provide China an efficient and direct access to the Indian Ocean that bypasses the Malacca straits. Since Pakistan's poor transportation infrastructure and electricity generation have been identified as the biggest impediments to development, it is these sectors that have received immediate investment. In fact, the first project funded by the Silk Road Fund was the $\$ 1.65$ billion Karot Hydropower Dam in northern Pakistan. ${ }^{840}$ Furthermore, one of the AIIB's first loans after its founding was directed at the construction of a highway connecting Pakistan's capital, Islamabad, to Faisalabad and Multan, two large cities in Pakistan's north-south corridor. The National Motorway M-4, as this project is called, would help connect Central Asia, southern Xinjiang, and various part of Pakistan to the seaports of Gwadar and Karachi, thus facilitating regional trade and providing access to international markets. ${ }^{841} \mathrm{~A}$ second

\footnotetext{
${ }^{839}$ See: "President Xi’s Article Published on Pakistani Paper," China Daily, April 19, 2015, http://www.chinadaily.com.cn/world/2015xivisitpse/2015-04/19/content_20474266.htm; "Building a China-Pakistan Community of Shared Destiny to Pursue Closer Win-Win Cooperation," Ministry of Foreign Affairs of the People's Republic of China, April 21, 2015, http://www.fmprc.gov.cn/mfa_eng/wjdt_665385/zyjh_665391/t1257158.shtml

840 "Commentary: Silk Road Fund's $1^{\text {st }}$ Investment Makes China's Words into Practice,” Xinhuanet, April 21, 2015, http://www.xinhuanet.com/english/2015-04/21/c_134170737.htm

841 "Islamic Republic of Pakistan National Motorway M-4 (Shorkot-Khanewal Section)," Asian Infrastructure Investment Bank, June 6, 2016, https://www.aiib.org/en/projects/approved/2016/_download/pakistan-nationalmotorway/document/approved_project_document_pakistan_national_motorway.pdf
} 
AIIB project in its first year of operations was directed at an upgrade project for the Tarbela Hydropower Dam. This project would increase the power output of the dam and alleviate some of the country's chronic blackouts, thus helping the public and private sectors ability to provide goods and services. ${ }^{842}$

Overall, since committing to investing in the CPEC, China's investment totals have continued to grow, increasing to $\$ 55$ billion in 2017 , before immediately expanding to $\$ 62$ billion by April. In fact, this figure only reflects money that is being invested directly by the Chinese government and its various national banks. The figure would be higher if private sector investment were included. ${ }^{843}$ There has also been significant progress in the various projects that have been announced. For example, in the energy sector, which includes hydropower, coal, wind, and solar plants, as well as coal mining operations, China has invested in 19 projects throughout Pakistan, seven of which have been completed or have entered commercial operation. ${ }^{844}$ This has resulted in the production of 4,050 megawatts of combined electricity, among five coal plants, five wind farms, and one solar park. ${ }^{845}$ In the transportation sector the two most important components are the upgrades

\footnotetext{
842 "Islamic Republic of Pakistan Tarbela 5 Hydropower Extension Project," Asian Infrastructure Investment Bank, December 9, 2016, https://www.aiib.org/en/projects/approved/2016/_download/pakistantarbela-5/approved_project_document_tarbela_5_hydropower_extension.pdf

${ }^{843}$ Fawad Ahmed, "China Raises CPEC investment from \$55 Billion to \$62 Billion Pakistan," CPEC Bulletin, April 17, 2017, https://cpecbulletin.com/2017/04/17/china-raises-cpec-investment-from-55billion-to-62billion-pakistan/

844 “CPEC Energy Projects,” CPEC China Pakistan Economic Corridor, http://cpec.gov.pk/

${ }^{845}$ Ibid.
} 
of the Karakorum Highway (KKH), its connection to Pakistan's National highway system, and upgrades to the port of Gwadar.

As indicated in the previous chapter, the KKH began receiving upgrades during the GWD strategy to facilitate overland transport between China and Pakistan. After severe floods in Pakistan in 2010, as well as an earthquake that caused mudslides, China and Pakistan agreed to restore the damaged sections and restore service. ${ }^{846}$ Since the agreement on $\mathrm{CPEC}$, upgrading the capacity of the $\mathrm{KKH}$ has been a core component of the corridor since it is the artery that connects the two neighbors. This Phase II picks up from the area what was restored in previous years, and moves south towards the Pakistan National Highway system. In the more remote areas of this section the road will begin as a simple two-lane highway, gradually expanding to a six-lane highway as it reaches major population centers north of Islamabad. ${ }^{847}$ The widest section of this project began construction in 2016 and is expected to be largely completed by $2018 .{ }^{848}$ Once integrated into the national highway system, the KKH splits into an eastern and a western route, which are also known as the eastern and western alignments. The eastern route connects Gwadar to Kashgar through Pakistan's most populated and industrialized regions, while the western route does so through less populated and underdeveloped areas. Although the eastern route

\footnotetext{
${ }^{846}$ See: "Feature: China-Aided Highway Changes Life of Pakistanis," Xinhuanet, April 20, 2015, http://www.xinhuanet.com/english/2015-04/20/c_134165479.htm; Irfan Haider, "PM Nawaz Inaugurates Pak-China Friendship Tunnels over Attabad Lake,” Dawn, September 14, 2015, https://www.dawn.com/news/1206911

847 "Senate Secretariat: Questions for Oral Answers and Their Replies," Senate of Pakistan, October 23, 2014, http://www.senate.gov.pk/uploads/documents/questions/1414066312_704.pdf

848 “CPEC Infrastructure Projects," CPEC China Pakistan Economic Corridor, http://cpec.gov.pk/progressupdate
} 
is less direct, it does provide the most immediate economic benefits as this is where most of Pakistan's economic activity occurs. The western route, on the other hand, provides better market access to less developed regions in Pakistan and increases national connectivity. ${ }^{849}$ According to Pakistan's CPEC Project Director, Hassan Daud, both routes will be completed by early $2019 .{ }^{850}$

Construction of Gwadar predates the CPEC. In fact, Chinese investment in the port began during the GWD strategy and began commercial operations in 2007. However, under the rubric of the CPEC, the port of Gwadar is currently being upgraded in order to increase capacity as well as render a variety of services. Also titled "Phase II," part of the upgrades includes the capacity to accommodate 50,000 dead weight ton (DWT) container ships, 100,000 DWT dry bulk carriers, and 200,000 DWT oil tankers. Furthermore, the port would be expanded to have three container terminals, one bulk cargo terminal, one grandhandling terminal, one twin-pier oil terminal, a breakwater, and 16-20-meter-deep approach channel. ${ }^{851}$ On 2017, Pakistan's Ambassador to China, Masoud Khalid, stated that Phase II of the port's upgrades should be completed by 2020 or 2021 by the latest. ${ }^{852}$

\footnotetext{
${ }^{849}$ See: Sajid Hussain and Muhammad Ayaz Khan, “CPEC; a Roadmap of Region's Development,” FWU Journal of Social Sciences 11(2), 2017, p. 51-52; Abdul Mateen Hashmi, "The Eastern, Western, and Central Route of China Pakistan Economic Corridor by Khuram Shahzad," Weekly Batieghar Islamabad, April 29, 2017, http://batieghar.com/index.php/2017/04/29/eastern-western-central-route-china-pakistaneconomic-corridor-khuram-shahzad/

850 "Eastern and Western Routes of CPEC to be Completed by 2019," Pakistan Today, June 29, 2017, https://www.pakistantoday.com.pk/2017/06/29/eastern-and-western-routes-of-cpec-to-be-completed-by2019/

851 “Gwadar’s Fact Sheet,” Gwadar International, http://www.gwadarinternational.com/facts.html

852 "Gwadar Port to be Fully Operational in Three to Four years - Pakistan Envoy to China," Gulf News, August 22, 2017, http://gulfnews.com/news/asia/pakistan/gwadar-port-to-be-fully-operational-in-three-tofour-years-pakistan-envoy-to-china-1.2078434
} 
Despite of the early stages of many of these projects, there have already been tangible results for both sides. Since the announcement of the corridor bilateral trade has increased. In the initial year after the announcement of the corridor there was a $124 \%$ increase in trade between China and Pakistan. ${ }^{853}$ In 2016, Xinjiang's Party Secretary, Zhang Chunxian (2010-2016), visited Pakistan and met with Sharif. During this visit, Zhang stated that "China and Pakistan have a deep friendship, are good neighbors, friends, brothers and partners," reifying the narrative of Sino-Pakistan relations. Additionally, Zhang and Sharif signed agreements worth $\$ 2$ billion in areas of infrastructure, solar power, and logistics. ${ }^{854}$ Central Asian countries have also expressed their interests in joining the CPEC ${ }^{855}$ with Tajikistan making concrete steps to establish road connection in $2015 .{ }^{856}$ By facilitating connectivity through its infrastructure projects, China is making it possible for Central Asian countries, as well as Pakistan, to finally reap the benefits of the 1995 Quadrilateral Traffic in Transit Agreement (QTTA). This agreement, signed by China, Kazakhstan, Kyrgyzstan, and Pakistan, provides Pakistan access to Central Asia through

\footnotetext{
${ }^{853}$ Sajid Hussain and Muhammad Ayaz Khan, "CPEC; a Roadmap of Region's Development," FWU Journal of Social Sciences 11(2), 2017, p. 55

854 “China’s Xinjiang Seals Pakistan Ties with \$2 Billion in Deals," Reuters, April 7, 2016, https://www.reuters.com/article/us-china-pakistan/chinas-xinjiang-seals-pakistan-ties-with-2-billion-indeals-idUSKCNOX507K

${ }^{855}$ See: "Kazakhstan Shows Willingness to Join CPEC Project," The News, August 26, 2015, https://www.thenews.com.pk/print/14270-kazakhstan-shows-willingness-to-join-cpec-project; "Future Linked to CPEC, PM Tells Turkmen President," Dawn, November 26, 2016, https://www.dawn.com/news/1298708; "Uzbekistan Considering Becoming Part of CPEC," The Nation, December 25, 2016, https://nation.com.pk/25-Dec-2016/uzbekistan-considering-becoming-part-of-cpec

856 "Three Highway Projects to Connect Pakistan with Tajikistan Approved," The News, November 14, 2015, https://www.thenews.com.pk/print/15662-three-highway-projects-to-connect-pakistan-withtajikistan-approved
} 
China, while providing Central Asian signatories access to Pakistan's seaports without paying duties. Furthermore, through the corridors and facilities that are outlined in the QTTA, signatories make use of uniform custom procedures, thus reducing costs and facilitating trade. However, poor infrastructure has severely limited the utility of this agreement. ${ }^{857}$ Furthermore, poor infrastructure has also stymied interregional relations. In other words, since economic activity was low due to poor infrastructure, the political engagement was also limited. The improvement of integrative infrastructure as a result of China's BRI, however, has begun to bridge the distance between these countries. Ultimately, it is evident that CPEC is important to China's development. This point was reiterated by China's Ambassador to Pakistan, Yao Jing, who on March 17, 2018, stated that Pakistan matters to China's vision of development and that a stable Pakistan was vital to China's growth. ${ }^{858}$

\section{Conditions for Success}

This phase of China's Eurasian foreign policy has had a number of successes. As indicated above, numerous projects have been completed and have increased connectivity between China and other Eurasian countries along several economic corridors. As a result, China has emerged not only as pivotal regional actor but also as the main driver of regional transformation. China's success can be attributed, in part, to its diplomatic narrative that links China's domestic development to the development of its neighbors. This narrative,

\footnotetext{
857 “USAID Trade Project: Analysis of Quadrilateral Traffic in Transit Agreement (QTTS)," USAID Trade Project, 2014, p. 4, http://pdf.usaid.gov/pdf_docs/PA00K24C.pdf

858 "Stability in Pakistan Integral to China's Development: Ambassador," The Nation, March 17, 2018, https://nation.com.pk/17-Mar-2018/stability-in-pakistan-integral-to-china-s-development-ambassador
} 
along with the shift in China's corporate practices and investment priorities during this period, have helped alleviate some of the concerns that many countries had developed over the course of the previous phase. For example, regarding corporate practices, Chinese companies began to address criticism regarding their use of Chinese labor in their foreign projects. As a result, many Chinese companies that take part in the BRI have begun to employ greater numbers of local workers. ${ }^{859}$

Furthermore, regarding its investment priorities, it is clear that as a result of the BRI's stated aims, China has focused on diversifying the sectors in which it invests. As indicated above, China has focused heavily on non-extractive sectors and instead has invested in transportation, electricity generation, and local industrialization. Although it has been claimed that this is the result of excess domestic capacity in China's construction industry, the focus on these sectors is primarily policy-driven due to Xi Jinping's aim of better integrating the region through infrastructure. Furthermore, the fact that China has not been the only beneficiary from the development of the BRI, evidenced from the number of international companies that have either partnered with Chinese firms or established independent projects of their own as a result of increased economic activity, indicates that the BRI is not entirely designed around offloading excess capacity ${ }^{860}$ Finally, since the BRI essentially builds on the successes of previous state-building initiatives, as a result it

\footnotetext{
${ }^{859}$ See: Dirk van der Kley, "Chinese Companies Increasingly Employ Central Asians," China in Central Asia, December 27, 2016, http://chinaincentralasia.com/2016/12/27/chinese-companies-increasinglyemploy-central-asians/; "Central Asia's Silk Road Rivalries," International Crisis Group, July 27,2017, p. 11-12, https://www.crisisgroup.org/europe-central-asia/central-asia/245-central-asias-silk-road-rivalries

${ }^{860}$ Steven McCord, "Belt Road Initiative Opens Up New Investment Opportunities," The Investor, June 8, 2017, https://www.theinvestor.jll/news/asia-pacific/bri/belt-road-initiative-opens-new-investmentopportunities/; Martin Arnold, Financial Times, February 26, 2018, https://www.ft.com/content/d9fbf8a6197d-11e8-aaca-4574d7dabfb6
} 
is primarily driven by an externalization of the security-development nexus logic, it would be inaccurate the characterize China's focus on infrastructure as an attempt to offload excess capacity in its domestic construction sector. Nevertheless, what is clear is that China's focus on these industries after the announcement of the BRI brought tangible political and economic benefits for the recipients of aid and FDI. The projects that have been completed, or proposed, by the BRI, provide a measure of political and economic diversification by increasing connectivity and access to international markets and lowering overdependence on a single actor. Thus, China has emerged as a public goods provider through the BRI. ${ }^{861}$

China's aid and FDI, despite criticisms of promoting white elephant projects, raising the debt of recipients, and being harmful to local economies, have actually demonstrated their capacity to generate economic activity and show success rates that parallel those provided by Western countries and Western-led financial institutions. ${ }^{862}$ For example, in Central Asia, China owns nearly half of the external government debt for Kyrgyzstan and Tajikistan, the two poorest republics in the region. However, the terms of the aid and loans received by these countries, despite their quantity, have not altered their

\footnotetext{
${ }^{861}$ See: Alexander Cooley, Great Game, Local Rules: The New Great Power Contest in Central Asia (Oxford: Oxford University Press, 2012), p. 173; Alexander Cooley, "China's Changing Role in Central Asia and Implication for US Policy: From Trading Partner to Collective Goods Provider," U.S.-China Economic and Security Review Commission, March 18, 2015, p. 1-2, https://www.uscc.gov/sites/default/files/Cooley\%20Testimony_3.18.15.pdf

${ }^{862}$ See: Adam Taylor, China Treats its Foreign Aid Like a State Secret. New Research Aims to Reveal It," The Washington Post, November 11, 2017, https://www.washingtonpost.com/news/worldviews/wp/2017/10/11/china-treats-its-foreign-aid-like-a-statesecret-new-research-aims-to-reveal-it/?utm_term=.4224b93f4184; Alvin Camba, "Fact-Checking Critics of Chinese Aid," East Asia Forum, November 28, 2017, http://www.eastasiaforum.org/2017/11/28/factchecking-critics-of-chinese-aid/
} 
respective debt-to-GDP ratios in any significant way. In fact, the success of the infrastructure programs that have been funded through this debt have increased the local government's ability to increase revenue, thus facilitating repayment. ${ }^{863}$ In other words, Chinese aid and loans have targeted important domestic growth sectors like infrastructure, power generation, and industrialization, and more importantly, they have had possible financial results.

This is something that is important for post-Soviet states that have relied heavily on the Russian Federation after the Soviet collapse. In essence, China's overtures through the BRI provide these countries the means to modernize their industries, increase domestic economic development, and increase their access to international markets; as a result, they have all eagerly participated in the initiative. ${ }^{864}$ An added bonus from the BRI is that although China has replaced Russia as a main economic partner for most post-Soviet states, its infrastructure projects also make it possible for many of these same countries to use the Chinese-built roads and railways to trade with other countries along the routes. In other words, even though the BRI clearly places China at the center of Eurasian integration, it also provides the means for Eurasian countries to diversify beyond China as well. Furthermore, Russia's annexation of Crimea in 2014 alarmed many of the post-Soviet states, which have now witnessed Russia interfere in the domestic affairs of a number of

\footnotetext{
${ }^{863}$ Dirk van der Kley, "Can Central Asia's Poorest Countries Pay Back Their Debts to China?" The Diplomat, December 1, 2017, https://thediplomat.com/2017/12/can-central-asias-poorest-states-pay-backtheir-debts-to-china/

864 "Central Asian Countries Are Actively Integrating in the "Belt and Road" Development in China," Renmin, July18, 2016, http://world.people.com.cn/n1/2016/0718/c1002-28563324.html
} 
former SSRs. ${ }^{865}$ This annexation has resulted in various economic sanctions form Western countries which have led to greater Russian dependency on China. As a result, China has emerged as Russia's primary political and economic partner, and despite Russian reservations about China's intentions with the BRI, it cannot afford to actively undermine it. 866

In the post-Soviet space, in countries like Iran and Pakistan, the BRI has had success due to China's long-standing partnership with both countries. For example, in Iran's case, China's continued support of Tehran during the sanctions period has positioned it as a reliable partner in the post-sanctions period. Furthermore, the loss of market access by Western companies during the sanctions period, as well as their concerns regarding potential American fines, even after the JCPOA, have left China as the main foreign investor in the country. It is also clear, as indicated above, that the two countries share similar normative foundations, particularly their criticisms of the West's efforts to universalize its political and economic norms. In the case of Pakistan, the relationship is more closely bounded by security concerns about Xinjiang and the need to generate codevelopment in southern Xinjiang as well as Pakistan. As Ambassador Yao Jing indicated, stability is Pakistan is crucial to China's development. The positioning of Pakistan in the

${ }^{865}$ See: Birgit Brauer, "Crisis in Crimea: Will Kazakhstan be Next? Eurasia Daily Monitor 11(48), March 13, 2014, https://jamestown.org/program/crisis-in-crimea-will-kazakhstan-be-next/; "Statement by the Ministry of Foreign Affairs of the Republic of Kazakhstan on the Situation on Southeastern Ukraine," Kazinform, March 3, 2014, http://www.inform.kz/en/statement-of-the-foreign-ministry-of-the-republic-ofkazakhstan-on-the-situation-in-ukraine_a2635749; "Statement of the Information Agency "Jahon" on the Events in Ukraine," Ministry of Foreign Affairs of the Republic of Uzbekistan, March 4, 2014, http://www.mfa.uz/en/press/statements/2014/03/6329/

${ }^{866}$ Alexander Gabuev "Friends with Benefits? Russian-Chinese Relations After the Ukrainian Crisis," Carnegie Moscow Center, June 29, 2016, http://carnegie.ru/2016/06/29/friends-with-benefits-russianchinese-relations-after-ukraine-crisis-pub-63953 
BRI highlighted its importance and came at a time of economic turmoil for Pakistan. In other words, the BRI, through its massive aid and investment offers, presented an excellent opportunity for Pakistan to escape its condition of economic stagnation. The ChinaPakistan Economic Corridor can help Pakistan modernize and achieve economic development at a time when its main rival, India, is being lauded as the next "China" due to its vibrant economic rise. This is particularly important since the Trump administration's National Security Strategy (NSS) depicts India as an emerging power and strategic partner, while casting Pakistan as a destabilizing force. ${ }^{867}$ Criticisms in the NSS and from the Trump Administration regarding Pakistan's role in the global war on terror and in Afghanistan have tightened the Sino-Pakistan relation. ${ }^{868}$

\section{$\underline{\text { Promoting Ideational Power }}$}

During this phase China has continued to build on its efforts to develop ideational power. As indicated throughout the previous and current chapter, China's sustained adherence to the Five Principles of Peaceful Coexistence, pluralism of development models, win-win outcomes, linkage of development, stability and security, and its securitization of the three evils, as the normative foundation of its state-to-state relations has found resonance in developing countries. Furthermore, by utilizing rhetoric that alludes to the historical relations between China and its Eurasian neighbors through the Silk Road, China

\footnotetext{
867 "National Security Strategy of the United States of America," The White House, 2017, https://www.whitehouse.gov/wp-content/uploads/2017/12/NSS-Final-12-18-2017-0905.pdf 2018, http://www.globaltimes.cn/content/1083361.shtml
} 
has carefully cultivated the historicity of its engagement with the region and consequently provided greater legitimacy to its increasingly dominant position in the region.

Developing ideational power grew in importance during the $\mathrm{Hu}$ Jintao administration. Under the Xi Jinping administration, however, China appears to be doubling down on this effort. As Xi stated, China should increase its soft power and give a "good Chinese narrative, and better communicate China's message to the world." ${ }^{869} \mathrm{Xi}$ also instructed Chinese media to play an active role in communicating China's message to the world, calling on them to "tell China's story well." ${ }^{870}$ It is China's economic success and its ability to help its neighbors achieve economic development through the BRI, that provide Beijing with the platform to promote ideational power, specifically its development model. This is something that $\mathrm{CCP}$ leaders have begun to realize during this phase. Xi Jinping's address at the $19^{\text {th }}$ National Congress of the Chinese Communist Party is explicit in its promotion of China's development success and offers this model as an "option for other countries and nations who want to speed up their development while preserving their independence." ${ }^{, 71}$ Although Xi has explicitly stated that China will not import foreign models or export its own, ${ }^{872}$ there is a concerted effort to present China's

\footnotetext{
869 “China's Xi Strikes Conciliatory Note, Broadens Diplomatic Focus," Reuters, November 30, 2014, https://www.reuters.com/article/us-china-southchinasea/chinas-xi-strikes-conciliatory-note-broadensdiplomatic-focus-idUSKCNOJE04J20141130

870 “China's Xi Urges State Media to Boost Global Influence," Reuters, February 19, 2016, https://www.reuters.com/article/us-china-media/chinas-xi-urges-state-media-to-boost-global-influenceidUSKCNOVS1IF

${ }^{871}$ Jinping Xi, "Full Text of Xi Jinping's Report at $19^{\text {th }}$ CPC National Congress," China Daily, November 4, 2017, http://www.chinadaily.com.cn/china/19thcpcnationalcongress/2017-11/04/content_34115212.htm

872 "China will not "Export" Chinese Model: Xi," Xinhuanet, December 1, 2017, http://www.xinhuanet.com/english/2017-12/01/c_136793674.htm
} 
model as successful and legitimate, in addition to being an alternative to the dominant Western-led liberal models. ${ }^{873}$ In other words, this is part of China's continued efforts to oppose the universalization of Western norms. In his address, Xi also highlighted how China's development has been the result of socialism and how its success provides a blueprint for developing countries to achieve modernization. ${ }^{874}$

For its part, Chinese media have followed Xi's lead in presenting the Chinese model as a blueprint for other developing countries. For example, People's Daily, has indicated how the CCP's development of socialism with Chinese characteristics had led to economic success in China and provides a model for developing countries to modernize. ${ }^{875}$ Another piece from the People's Daily argues that the "Chinese story provides a reference for the development of other countries in the world and provides inspiration for the common development of all countries." 876 This article also quotes foreign diplomats and scholars present at Xi Jinping's $19^{\text {th }}$ Congress address giving support to the Chinese model and its utility to developing countries. ${ }^{877}$ An article from Xinhua also highlights how China's development miracle cannot be attributed to other "-isms," adding that the country's

\footnotetext{
${ }^{873}$ Bonnie S. Glaser, "Is China Proselytising its Path to Success? East Asia Forum, January 11, 2018, http://www.eastasiaforum.org/2018/01/11/is-china-proselytising-its-path-to-success/

874 Jinping Xi, “Full Text of Xi Jinping's Report at $19^{\text {th }}$ CPC National Congress," China Daily, November 4, 2017, http://www.chinadaily.com.cn/china/19thcpcnationalcongress/2017-11/04/content_34115212.htm

${ }^{875}$ Kai Yang, "The More Powerful the CCP is, the Better the World Is," Renmin, October 1, 2017, http://paper.people.com.cn/rmrbhwb/html/2017-10/18/content_1811226.htm

876 "Nineteenth Congress: China’s Smart China Program Affects the World," Renmin, October 24, 2017, http://paper.people.com.cn/rmrb/html/2017-10/24/nw.D110000renmrb_20171024_6-01.htm

877 Ibid.
} 
success is the result of adapting ideas of socialism to the local conditions of China, i.e., socialism with Chinese characteristics. The article argues that this model "has been successful, both politically and economically," and that despite criticisms, it "has benefited the rest of the world in commerce, trade, investment and international peace." 878 Furthermore, the article indicates that by 2016 , there were 13 countries with a population over 100 million people, 10 of which were developing countries, adding that China's success proves that "socialism can prevail and be a path for other developing countries to emulate and achieve modernization." $" 879$

These articles point to an increasingly proactive effort to present China's development model as successful, legitimate, and as an alternative to the dominant Western-led liberal norms. In fact, the Xinhua article explicitly states that the "new world order cannot be just dominated by capitalism and the West, and the time will come for a change." ${ }^{880}$ Although not as explicit, Foreign Minister Wang Yi indicated that China was setting an example in international relations as well as development that was different from traditional powers. ${ }^{881}$

\footnotetext{
${ }^{878}$ Hui Lu, "Commentary: Milestone Congress Points to a New Era for China, the world," Xinhuanet, October 24, 2017, http://www.xinhuanet.com/english/2017-10/24/c_136702090.htm

879 Ibid.

880 Ibid.

881 "Wang Yi Talks about General Goal of Major Country Diplomacy with Chinese Characteristics in New Era: To Promote the Building of a Community with Shared Future for Mankind," Ministry of Foreign Affairs of the People's Republic of China, October 19, 2017, http://www.fmprc.gov.cn/mfa_eng/zxxx_662805/t1503758.shtml
} 
Beyond the promotion of its development model, China has created the "World Political Parties Dialogue" as a forum that brings political parties from around the world in order to seek common ground, learn from each other, and increase cooperation. ${ }^{882}$ At its inaugural meeting on December 1, 2017, this forum attracted representatives from more than 120 countries with over 600 delegates present. ${ }^{883}$ According to Guo Yezhou, Vice Minister of the International Liaison Department, the CCP department running this forum, one of the reasons to hold the World Political Parties Dialogue was to "comprehensively introduce the spirit of the 19th Party Congress, deeply expound on Xi Jinping Thought on Socialism with Chinese Characteristics for a New Era, and systematically introduce the CCP's proposition on building a community with a shared future for mankind." 884 This message was supplemented by State Council member, Yang Jiechi, who stated that the meeting provided an opportunity for CCP officials to elaborate on the theoretical and practical outcomes of the $19^{\text {th }}$ Party Congress, their significance for China, but more importantly, the examples they set for developing countries. ${ }^{885}$ Delegates from BRI

\footnotetext{
${ }^{882}$ Xin Liu and Xianglin Meng, "Xi Offers Model for Governance," Global Times, December 1, 2017, http://www.globaltimes.cn/content/1078275.shtml

${ }^{883}$ Yuting Su, "World Political Parties Dialogue Concludes with 'Beijing Initiative," China Global Television Network, December 3, 2017, https://america.cgtn.com/2017/12/03/world-political-partiesdialogue-beijing-initiative

${ }^{884}$ Charlotte Gao, "For the First Time, Chinese Communist Party to Hold a World Political Parties Dialogue," The Diplomat, November 29, 2017, https://thediplomat.com/2017/11/for-the-first-time-chinesecommunist-party-to-hold-a-world-political-parties-dialogue/

${ }^{885}$ Yuting Su, "World Political Parties Dialogue Concludes with 'Beijing Initiative," China Global Television Network, December 3, 2017, https://america.cgtn.com/2017/12/03/world-political-partiesdialogue-beijing-initiative
} 
participant countries expressed their support for the meeting and the signal that China was shouldering greater international responsibilities. ${ }^{886}$

This forum essentially allows China to present its governance model as successful, and as a potential model to other developing countries. In fact, Xi Jinping has called China's system of multiparty cooperation and political consultation, led by the CCP, as a "great contribution to political civilization of humanity." 887 Furthermore, while the World Political Parties Dialogue is new, the CCP has hosted annual summits with political party leaders from around the world since $2014,{ }^{888}$ in addition to promoting greater political and judicial cooperation with countries with which it elevates partnerships. Evidence of this is found in both the Iranian and Pakistan blueprints for cooperation. ${ }^{889}$

In addition to promoting its development and governance model in recent years, China has continued to build on its efforts to enhance its cultural appeal, particularly through people-to-people exchanges and the Confucius Institutes. During his announcement of the BRI, Xi Jinping offered a 10-year plan to provide 30,000 scholarships

\footnotetext{
${ }^{886}$ See: Xin Liu and Xianglin Meng, "Xi Offers Model for Governance," Global Times, December 1, 2017, http://www.globaltimes.cn/content/1078275.shtml; Yuting Su, "World Political Parties Dialogue Concludes with 'Beijing Initiative," China Global Television Network, December 3, 2017, https://america.cgtn.com/2017/12/03/world-political-parties-dialogue-beijing-initiative

887 “China's Party System is Great Contribution to Political Civilization," Xinhuanet, March 5, 2018, http://www.xinhuanet.com/english/2018-03/05/c_137015955.htm

${ }^{888}$ See: Lily Kuo, "Beijing is Cultivating the Next Generation of African Elites by Training them in China," Quartz, December 14, 2017, https://qz.com/1119447/china-is-training-africas-next-generation-ofleaders/; Zheping Huang, "Xi Jinping Says China's Authoritarian System Can Be a Model for the World," Quartz, March 9, 2018, https://qz.com/1225347/xi-jinping-says-chinas-one-party-authoritarian-system-canbe-a-model-for-the-world/

${ }^{889}$ See: "President Xi's Article Published on Pakistani Paper," China Daily, April 19, 2015, http://www.chinadaily.com.cn/world/2015xivisitpse/2015-04/19/content_20474266.htm; "Full Text of Joint Statement on Comprehensive Strategic Partnership Between I.R. Iran, P.R. China," President of the Islamic Republic of Iran, January 23, 2016, http://www.president.ir/en/91435
} 
to members of the SCO, in addition to inviting 10,000 teachers and students from the Confucius Institutes of these countries to study tours in China. ${ }^{890}$ There are indications that China's efforts are beginning to have a measurable effect. For example, China's education ministry has stated that "the number of international students in China from One Belt, One Road countries like India, Pakistan and Kazakhstan saw an increase of over 10\% in 2015 from a year earlier, which is the largest increase among the top 15 countries that sent students to China." ${ }^{891}$ Furthermore, Tian Xuejun, China's Vice Minister of Education, revealed that the 53 Confucius Institutes that have emerged in BRI participant countries are currently teaching Mandarin classes to over 460,000 students. According to Tian, the Chinese government sought to increase its support for students studying in China who originate from BRI participant countries. He adds that these international exchange students are ambassadors for different cultures and civilization. ${ }^{892}$ In many ways this reflects similar programs initiated by the United States and European countries in order to enhance their ideational power.

As indicated in the previous chapter, much of the appeal to learn Mandarin is correlated with China's growing economic presence in many of the BRI participant countries. For example, prior to the announcement of CPEC, roughly 200 students took Mandarin at Islamabad's National University of Modern Languages. However, after

\footnotetext{
${ }^{890}$ Jiao Wu and Yunbi Zhang, "Xi Proposes a 'new Silk Road' with Central Asia," China Daily, September 8, 2013, http://usa.chinadaily.com.cn/china/2013-09/08/content_16952304.htm

${ }^{891}$ Wanxia Lin, "Silk Road Scholarships to Expand China's Links to Eurasia," Asia Times, November 28, 2016, http://www.atimes.com/article/silk-road-scholarships-expand-chinas-links-eurasia/

${ }^{892}$ Cal Wong, “One Belt, One Road, One Language?” The Diplomat, May 12, 2017, http://thediplomat.com/2017/05/one-belt-one-road-one-language/
} 
Chinese investment began pouring in, the number of Mandarin students grew to over 2,000. ${ }^{893}$ While Mandarin is starting from a low number of speakers across Eurasia, thus giving Chinese authorities the ability to tout large year-over-year growth figures, it is clear that there is an increasing appeal to learn Mandarin as national economies become more integrated with China's. Even countries like Turkmenistan that do not have a Confucius Institute, have increasingly begun to offer Mandarin language courses at their universities. ${ }^{894}$

In addition to the Confucius Institutes, Chinese Universities have set up partnerships and NGOs like the University Alliance of the New Silk Road (UANSR) with countries along the Silk Road Economic Belt in order to set up policy programs, joint labs, summer schools, and elite training programs. ${ }^{895}$ The UANSR, initiated by Xi'an Jiaotong University in 2015, includes 134 universities from 34 countries along the Silk Road Economic Belt. According to Xi' an Jiaotong University, the purpose of the UANSR is to build
"a platform in higher education cooperation and promoting regional openness and development and vows to step up exchanges and collaboration among universities from countries and regions along the Silk Road in institutional exchanges, talent training, joint research, cultural communication, policy studies and medical service etc, enhance understanding and friendship between the young people, foster quality and all-round talents with international visions, and facilitate the economic growth of countries on the New Silk Road Economic Belt and the Eurasian region." ${ }^{896}$

\footnotetext{
${ }^{893}$ Shah Meer Baloch, "Why are Pakistanis Keen to Learn Chinese Language? DW, November 21, 2017, http://www.dw.com/en/why-are-pakistanis-keen-to-learn-chinese-language/a-41465711

894 "Ruzlan Izimov: China and Turkmenistan - a Regional Dimension," Central Asia Bureau for Analytical Reporting, August 29, 2016, http://cabar.asia/en/ruslan-izimov-china-and-turkmenistan-a-regionaldimension/

${ }^{895}$ Wanxia Lin, "Silk Road Scholarships to Expand China's Links to Eurasia," Asia Times, November 28, 2016, http://www.atimes.com/article/silk-road-scholarships-expand-chinas-links-eurasia/

896 "XJTU Initiated the University Alliance of the New Silk Road," Xi'an Jiaotong University, May 22, 2015, http://en.xjtu.edu.cn/info/1043/1706.htm
} 
Initiatives like these not only provide greater access to students in developing countries to higher education opportunities in China, but also provide Beijing with an organization that has not developed the same type of baggage that the Confucius Institutes have acquired in Western countries. Ultimately, while China is competing with dominant languages like Russian and English across Eurasia, it has managed to carve a place for Mandarin as a valuable second or third language across the region. Much like the appeal of its development model, or even its governance model, Mandarin's appeal rest squarely in China's ability to demonstrate its economic success domestically, as well as abroad.

\section{$\underline{\text { Conclusion }}$}

This phase has seen yet another expansion of China's state-building efforts and a consequent expansion of its Eurasian region-building project. The most important development, however, has been the transformation in the understanding of the securitydevelopment nexus logic among the upper echelons of CCP leadership. In essence, there was a realization that the development of China, particularly its western provinces, was contingent on the development of Asia. Furthermore, understanding the absence of markets and integrated supply chains along the Eurasian Center, the CCP resolved to integrate them where they existed or create them where they did not. As a result of the explicit codevelopment logic in this third phase, the state-building and region-building projects become more intrinsically linked. This is why the BRI can be understood as both, a statebuilding initiative and a region-building project.

By design, the geographic boundaries of the BRI encompass the entirety of the Eurasian continent. Nevertheless, a project of this scope ultimately hinges on a core set of 
countries that can make the larger project feasible (see map 10). This study focuses on the five Central Asian republics, Iran, and Pakistan since these are the countries that have been identified as being more intimately linked to the stability and development of Xinjiang, the mitigation of China's Malacca Dilemma, their role as gateways to markets in Europe or Southwest Asia, and more broadly, to the two centenary goals. Thus, although the geographic boundary of China's Eurasian region-building project has expanded during this phase, it is evident that Beijing has spent much time and effort to consolidate its political, economic, and social gains with countries.

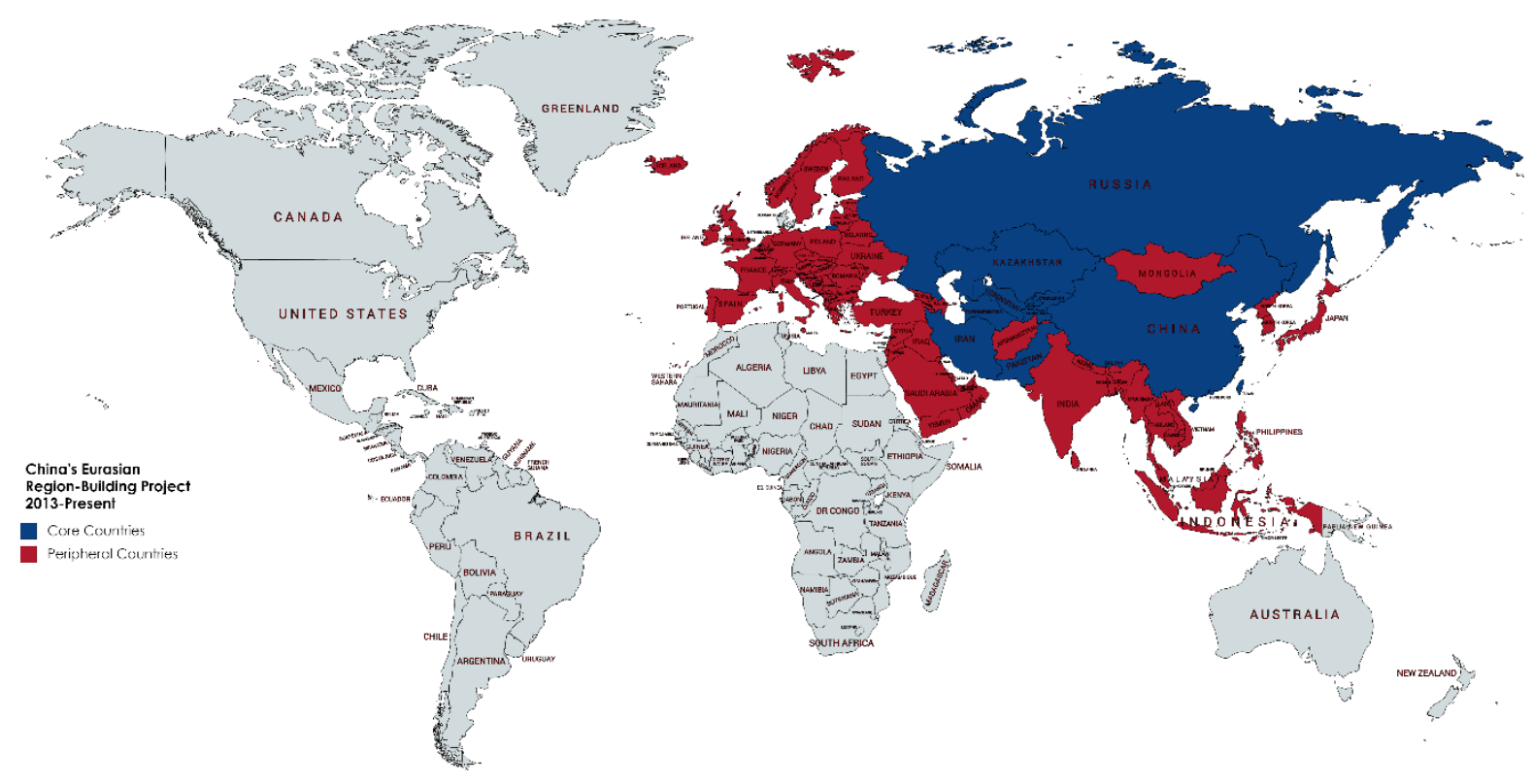

Map 10: China's Eurasian Region-Building Project 2013-Present. Generated from https://mapchart.net/world.html 


\section{Conclusion}

Since 1949, CCP officials have been preoccupied with efforts to increase state capacity in order to exercise more effective control over the PRC's vast western frontier and to generate the conditions for economic development. These state-building initiatives have always incorporated an international component. However, since the collapse of the USSR, the international component of domestic state-building efforts has necessitated an accompanying region-building project in Eurasia to improve the likelihood of their success. This is due to the increasingly complex geopolitical environment created by the Soviet collapse, the geographical remoteness of China's western regions, and the transnational character of the global economy and the three evils. These region-building projects are mechanisms that enable engagement between China, its post-Soviet neighbors, and other pivotal Eurasian states. At their fundamental level, these projects are intended to facilitate China's control of its western frontier, particularly through the recognition of China's securitization of the three evils and respect for sovereignty and territorial integrity. Furthermore, these projects also allow China to have access to Eurasia's markets and resources, thus providing China's western provinces access to international markets and the ability to create new supply chains. In other words, region-building projects provide the means for the development of western China. However, beyond the domestic imperative of these region-building projects they also possess crucial international implications. In essence, they form and transform regions in a manner that results in greater orientation towards China.

This study reveals three different state-building initiatives that possess an accompanying region-building project. Since the state-building initiatives are driven by a 
security-development nexus logic, so are the region-building projects. In essence, the rhetoric that is used to promote these projects regularly alludes to the relationship between security, social stability, and development, as well as the role of the state in the provision of these public goods. Furthermore, development is regularly presented as the means to combat the three evils, a concept that can be easily applied to the local conditions of various countries along China's western frontier. Beyond the security-development nexus, the CCP regularly refers to the historicity of relations between China and its neighbors, particularly by invoking the historical Silk Road. This allows Chinese officials to situate China and the target state within the region-building project they are promoting. There are also consistent appeals to important international norms that are implicitly presented as alternatives to Western-led liberal norms. In some respects, a number of the norms that Chinese officials refer to were initially internationalized by the West, such as sovereignty. However, Western interference in the domestic and international affairs of developing countries, either through invasion or by imposing political and economic conditions on these countries undermines the principle of the full autonomy that states enjoy as sovereign nations. As a result, China regularly emerges as a staunch supporter of non-interference and the protection of sovereignty and territorial integrity in inter-state relations. Much of this is influenced by China's own experience during the " 100 years of national humiliation." Other norms, however, such as the plurality of development or governance models, present a clear challenge to dominant international norms like the Washington Consensus and democracy. Doing this allows China to express its solidarity with the global south, thus increasing the appeal of its region-building projects. 
The Double-Opening and the "Shanghai Five"

The Sino-Soviet rapprochement in the 1980s resulted in the resumption of trade between China and Soviet Central Asia. However, the Soviet collapse presented China with a series of challenges in addition to a vital strategic opening. As indicated in Chapter 2, Central Asian independence raised the specter of separatism in Xinjiang, thus creating the imperative to better integrate the province into the rest of the country in order to exercise more effective control, improve the economic conditions of the province, and mitigate ethnic violence. The role of key Eurasian states in the security and development of Xinjiang was immediately apparent in discourses within the CCP. As a result, the double-opening strategy called for the simultaneous integration of the province into the rest of the country and its opening to Eurasian markets. Opening the province to Eurasia carried serious consequences, particularly the possibility of extremist ideas and groups having the ability to penetrate Xinjiang and undermine Chinese control. Thus, China aimed to address existing border demarcation, delineation, and demilitarization with the post-Soviet states in order to secure their support against the three evils. The Shanghai Five summits became an explicit reflection of China's region-building project during this period. Although the Shanghai Five was an informal group, the shared norms of non-interference, consensus decision-making, and support against the three evils not only allowed China to move forward with its double-opening strategy, but also generated a new regional grouping that began to define the post-Soviet space in Eurasia. Based on the scope of the state-building initiative, the geographical parameters of the region-building project was limited to China, Russia, Kazakhstan, Kyrgyzstan, and Tajikistan. 


\section{The GWD, the SCO, and Beyond}

Although the double-opening strategy and the Shanghai Five summits resulted in greater state capacity, control, and development in Xinjiang, they did not effectively address the development gap between western and coastal provinces or the north-south gap within Xinjiang. Furthermore, violence within Xinjiang continued to grow during the 1990s and by 2001, the global war on terror resulted in even greater concerns within the CCP that China's western frontier could become more unstable. Lastly, from the perspective of Chinese leaders, China's growing dependency on the maritime commons for exporting its goods as well as securing sufficient energy supplies created an Achilles heel.

The Great Western Development strategy was designed to address the widening national development gap as well as Xinjiang's north-south divide. This would be accomplished by consolidating Xinjiang's integration into the rest of the country and focusing on the connectivity and development of the southern portion of the province. Additionally, the province's energy resources could be tapped meet the demands of the coastal provinces and help mitigate energy security concerns. Nevertheless, the financial costs of the GWD strategy also required greater efforts to open China's western provinces to Eurasia and attract FDI. Here again, Xinjiang was seen as the gateway into the region. Furthermore, it became increasingly apparent that Xinjiang's capacity to meet the energy demands of the coastal provinces was limited, thus CCP officials needed to acquire access to Eurasian hydrocarbon resources. Lastly, the Malacca Dilemma necessitated a partner that could provide an overland route to the Indian Ocean that bypassed the Malacca Straits. 
These domestic imperatives resulted in the expansion of China's region-building project. For example, Beijing sought to institutionalize the gains, particularly cooperation against the three evils made through the Shanghai Five, and created the Shanghai Cooperation Organization. Creating the SCO added the Uzbekistan to the region-building program since its cooperation against the three evils, ability to supply some of China's energy demands, and provide transit for Turkmenistan's vast natural gas reserves made it an important component of China's domestic state-building efforts. Furthermore, Turkmenistan, Pakistan, and Iran became increasingly pivotal to China's state-building efforts but were not full members of the SCO. Despite not being part of the "formal" region that China had developed through the creation of the SCO, these countries became increasingly incorporated in Chinese domestic narratives about Eurasia due to their geographical proximity and the role they played in China's domestic state-building efforts. For example, Turkmenistan provided China with overland access to vast natural gas sources, thus mitigating the Malacca Dilemma. Pakistan, on the other hand, provided China with access to the Indian Ocean that bypassed the Malacca Straits. Finally, Iran allowed China to diversify its source of oil imports and represented not only a major export market for Chinese goods, but also the gateway to Southwest Asia. Thus, the geographical scope of the region-building project expanded to China, Russia, the five Central Asian republics, as well as Pakistan and Iran during this period.

The Belt Road Initiative and Eurasian Re-Connection

Like the double-opening strategy and the Shanghai Five, the GWD strategy, the SCO, and China's extended Eurasian foreign policy resulted in greater state capacity, 
control, and development within Xinjiang as well as other western provinces. Furthermore, it cemented China's position as a major player in Eurasian affairs. However, China's domestic development gap continued to widen and the goal of attracting greater FDI to its western provinces had not materialized in a degree that would help China achieve its domestic development goals. This condition was limiting China's efforts to accomplish its two centenary goals. As a result, the Belt Road Initiative was developed to link China's most underdeveloped provinces to international markets. Furthermore, these links would also provide coastal provinces overland access to emerging markets and allow for the development of more effective domestic supply chains by linking coastal cities to emerging inland industrial centers, thus integrating the national economy. The most important development of the BRI, however, was the transformation of the security-development nexus from a purely domestic logic, to one that was now explicitly linked to China's Eurasian neighbors. In other words, the security and development of China, and especially Xinjiang, was contingent on the development of its Eurasian neighbors. Thus, in needing to link western China to Eurasian markets and realizing that these were largely absent, China resolved to create them by providing greater connectivity, aiding in electricity generation, and facilitating the industrialization of these countries. This has resulted in an increasingly interconnected Eurasia where the sub-regions are gradually becoming integrated through economic corridors.

The BRI is a state-building effort that aims to accomplish the two centenary goals. Xinjiang, as the gateway for three major economic corridors plays a pivotal role within the BRI. Furthermore, the region-building project becomes more explicit in this phase by outlining the countries that are incorporated into the six official corridors. The NELB, the 
CCAWAEC, and the CPEC incorporate the same countries that were the focus of China's second phase of Eurasian foreign policy, while adding dozens of countries spanning the Caucasus, Southwest Asia, and Europe. This would indicate that China's region-building project now encompasses the entire continent of Eurasia. However, in a project this ambitious, there are layers that illustrate which countries are more relevant than others, and consequently affect how narratives are employed in order to incorporate these countries into the region-building project. Using the state-building initiative as the lens reveals that the same countries that were crucial during the GWD strategy, remain the most relevant for China's Eurasian region-building project. For example, for the security of China's western frontier, Russia, Kazakhstan, Kyrgyzstan, Tajikistan, Afghanistan, and Pakistan play the largest roles. For access to European markets, Russia and Kazakhstan currently play the largest role. For bypassing the Malacca Straits and access to the Southwest Asian market, Pakistan and Iran play the main roles respectively. For energy security and diversification, Russia, Kazakhstan, Turkmenistan, and Iran play the most important role. Lastly, for securing access to major emerging markets to its west, Pakistan and Iran are the most important. Since these countries remain the focus of China's region-building project, they have become gradually connected through physical infrastructure, but more telling, they have become increasingly linked within China's narratives about Eurasia.

On the surface, China's state-building initiatives, along with their accompanying regional-building projects, appear different. However, it is more accurate to describe them as evolutionary phases where the preceding phase makes the next one possible. In essence, as China is able to meet certain domestic goals, it uses the existing platform to reach the next level. Furthermore, as its region-building projects become increasingly complex and 
ambitious, China is not only creating regional groupings within Eurasia, it is also transforming the continent. Consequently, despite the domestic imperatives that drive China's region-building projects, they possess significant international implications not only for Eurasia, but also for global order. However, it should be noted that although China has promoted region-building projects in Eurasia, these projects are not intended to generate supranational entities akin to the EU. Even China's most institutionalized project, the SCO, operates in a mutual-consensus format that more closely resembles ASEAN. By design, China's region-building projects remain informal and are largely driven by shared understandings or socialization of norms as well as physical infrastructure that increasingly links its members.

\section{Contributions}

This study makes four contributions, one theoretical and three empirical. Theoretically, it contributes a synthesis between the region-building approach and regionalization. This not only provides a framework for unearthing and assessing narratives

around regional construction, but also for tracing the process and mechanisms that are used to bring about the empirical creation and transformation of a region. Empirically, it reveals how China's region-building projects since 1991 have been primarily driven by domestic state-building initiatives. In other words, China's rhetorical and empirical construction of regions has been motivated by domestic efforts to effectively integrate its frontier regions into the political and economic center of the country and to provide economic development in order to mitigate ethnic tensions. This indicates that China's state-building initiatives, and by extension its region-building projects, are underpinned by a security-development 
nexus logic in which the state plays a central role in the provision of security and development.

In addition to externalizing narratives about security and development, China's region-building project is promoted through the establishment of the historicity of China's engagement in Eurasian affairs and its support for various norms of non-interference. Furthermore, it demonstrates how China's region-building projects have gradually transformed the region in a manner that has resulted in its eastward orientation, particularly through the usage of connective infrastructure and co-development projects that place China at the center of Eurasian transformation. Consequently, it demonstrates how China has emerged as a dominant power in Eurasian affairs that not only exercises significant political and economic power, but more importantly, ideational power.

\section{$\underline{\text { Regional Transformation }}$}

China's Eurasian region-building projects, as extensions of its domestic statebuilding efforts, have, over time, generated an increasingly interconnected Eurasia. Furthermore, since these projects emanate from Chinese domestic imperatives, the transportation infrastructure effectively places China at the center of Eurasian connectivity. In other words, the adage that "all roads lead to Rome" is becoming a real possibility for China as Eurasian roads, railways, and energy pipelines begin to lead towards China. The degree of connectivity and interdependence varies, however, particularly since China's region-building projects have gradually expanded to include new countries in their scope over time. Nevertheless, as this study demonstrates, there has been a gradual geopolitical, economic, and social reorientation in Eurasia, particularly Eurasia's center, towards China. 
China's increasingly dominant position in this area has resulted in greater capacity for local states to diversify politically and economically. For post-Soviet states this has meant less reliance on Russia for economic matters, which consequently provides them with a measure of political autonomy that was difficult to attain prior to China's engagement in the region. It is important to note that while China has become the main economic actor in this region, its investment in Eurasian countries, particularly under the BRI, is generating improved local economic conditions and providing the means to not only diversify from Russia through China, but also from China by providing access to South Asian, Southwest Asian, and European markets through the infrastructure that it has gradually built. Thus, China has effectively become a public goods provider for a number of Eurasian countries. These patterns are also applicable in Pakistan's and Iran's cases. However, rather than diversification from just Russia, China is also providing diversification, and in some cases, insulation, from Western powers and the Western order.

\section{Implications}

China's transformation of Eurasia, particularly Eurasia's center, has important implications for regional and global order. At the regional level, it is evident that Eurasia has provided China with the most effective platform for establishing a dominant position. It has not only become the primary economic actor in the region, but geopolitically and ideationally, China has found greater success in Eurasia than in any other region, especially East Asia where it possesses significant historical and contemporary baggage. In East Asia, China faces an American system of alliances and strategic partnerships that moderate its ability to generate a cohesive region-building project. Furthermore, its increasingly 
assertive behavior regarding existing territorial disputes in the East and South China Sea has resulted in a mixture of balancing and hedging behavior by various East and Southeast Asian countries, thus limiting China's influence in the regions beyond its economic presence. This means that despite the fact that China possesses significant economic power in these regions, its political and ideational sway remains limited. It can be argued that since China's region-building projects have thus far been primarily driven by domestic state-building imperatives, there has been no necessity to pursue one in East and South East Asia since China's coastal provinces have been part of the historical core of successive Chinese governments, unlike the western multi-ethnic provinces. In other words, China's coastal provinces have been better integrated into the political, economic, and social core of China than their western counterparts. Thus, rather than East Asia, as it is regularly assumed by academics and analysts, it is in Eurasia where China has established a dominant position.

The eastward reorientation of key states in Eurasia as a result of China's regionbuilding projects also has implications for global order, particularly in the context of the ideational power that China has slowly cultivated in the region. The norms of noninterference, pursuit of multipolarity, and plurality of development and governance systems, allow China to present a legitimate alternative to the dominant Western-led liberal-normative order. Furthermore, as China develops global financial institutions in order to address the representative imbalance that exists within Western-led financial institutions, it has gradually become more proactive in the global financial sector. As a result, China is demonstrating its willingness to play a greater role in global affairs. Although this should not be perceived as revisionist behavior since China has not taken 
any major steps to undermine the existing global order (in fact, it continues to benefit greatly from it), it certainly represents an effort to carve out a place in the current order that is more reflective of China's position as a global power. As China's Eurasian regionbuilding projects evolve and mature, as they have done since 1991, they will have a profound effect not only on a wider range of states in Eurasia, but also on the role that China will play internationally since these states form a key base of China's domestic and international power. 


\section{LIST OF REFERENCES}

"1.8bn Tajik Aluminum Plan Deal highlights China's Growing Influence in Central Asia," Eurasian Business Briefing, November 22, 2017, http://www.eurasianbusinessbriefing.com/1-5bn-tajik-aluminium-plant-deal-highlightschinas-growing-influence-central-asia/

" 3 rd Freight Train from China to Arrive in Tehran Within Days," Mehr News Agency, January 6, 2018, https://en.mehrnews.com/news/130965/3rd-freight-train-from-China-toarrive-in-Tehran-within-days

"A Comment on the Statement of the Communist Party of the U.S.A." People's Daily, March 8, 1963, http://www.marx2mao.com/Other/CCP2CPUSA63.pdf

"A Peaceful Europe - The Beginning of Cooperation," European Union, https://europa.eu/european-union/about-eu/history/1945-1959_en

“About Confucius Institute/Classroom," Hanban, http://english.hanban.org/node_10971.htm

"Agreement on Regional Anti-Terrorist Structure between the Member States of the Shanghai Cooperation Organization," The Shanghai Cooperation Organization, June 7, 2002, http://eng.sectsco.org/documents/

"Agreement Between the Governments of the Member states of the Shanghai Cooperation Organization on Creating Favorable Conditions for International Road Transportation," The Shanghai Cooperation Organization, 2014, http://eng.sectsco.org/documents/

“Agreement between the Kyrgyz Republic, People's Republic of China, and the Republic of Tajikistan on the Point of the Joint Frontiers of Three States," CIS-Legislation, 2000, http://cis-legislation.com/document.fwx?rgn=4948

"Agreement between the Republic of India and the People's Republic of China on Trade and Intercourse between the Tibet Region of China and India," signed in Beijing April 29, 1954, https://treaties.un.org/doc/publication/unts/volume\%20299/v299.pdf

"Agreement between the Republic of Kazakhstan and the People's Republic of China on the Kazakhstan-China international border, signed in Almaty on April 26, 1994," Ministry of Justice of the Republic of Kazakhstan, 1994, http://adilet.zan.kz/rus/docs/U950002331_\#z5 [Source in Russian]

"Agreement on General Principles for the Settlement of the Questions Between the Republic of China and the Union of Soviet Socialist Republics," The American Journal of International Law 19(2), 1925, p. 53-56 
"As the Construction of Turkmenistan's Largest Pipeline is Halted, the Country's Crisis Worsens," Asia News, March 13, 2017, http://m.asianews.it/news-en/As-the-constructionof-Turkmenistan $\%$ E2\%80\%99s-largest-pipeline-is-halted,-the-country\%E2\%80\%99scrisis-worsens-40181.html

"Astana Declaration by Heads of Member States of the Shanghai Cooperation Organization," The Shanghai Cooperation Organization, 2005, http://eng.sectsco.org/documents/

"Belt, Road, and the Xinjiang Issue," Singapore Management University, August 31, 2017, https://www.smu.edu.sg/perspectives/2017/08/31/belt-road-and-xinjiang-issue

"Bishkek Declaration by Heads of Member States of the Shanghai Cooperation Organization, The Shanghai Cooperation Organization, 2007, http://eng.sectsco.org/documents/

"Bishkek Declaration of Heads of State of the Republic of Kazakhstan, People's Republic of China, Kyrgyz Republic, Russian Federation and Republic of Tajikistan," CIS-Legislation, August 25, 1999, http://cis-legislation.com/document.fwx?rgn=3878

"Building a China-Pakistan Community of Shared Destiny to Pursue Closer Win-Win Cooperation," Ministry of Foreign Affairs of the People's Republic of China, April 21, 2015, http://www.fmprc.gov.cn/mfa_eng/wjdt_665385/zyjh_665391/t1257158.shtml

"Cargo Train Services Launched Between Yinchuan, Tehran," China Daily, September 6, 2017, http://www.chinadaily.com.cn/business/2017-09/06/content_31626069.htm

"Central Asian Countries Are Actively Integrating in the "Belt and Road" Development in China," Renmin, July18, 2016, http://world.people.com.cn/n1/2016/0718/c100228563324.html

"Central Asia's Silk Road Rivalries," International Crisis Group, July 27,2017, p. 11-12, https://www.crisisgroup.org/europe-central-asia/central-asia/245-central-asias-silk-roadrivalries

"Central Asia-China Gas Pipeline, Turkmenistan to China," Hydrocarbons-Technology, https://www.hydrocarbons-technology.com/projects/centralasiachinagasp/

"Charter of the Shanghai Cooperation Organization," The Shanghai Cooperation Organization, June 7, 2002, http://eng.sectsco.org/documents/

"China," The World Bank, 2018, https://data.worldbank.org/country/china

"China," European Commission, http://ec.europa.eu/trade/policy/countries-andregions/countries/china/

"China Agrees to Dispatch Two Freight Trains to Iran Every Month," Iran Daily, October 2, 2017, http://www.iran-daily.com/News/201621.html 
“China: Assimilating or Radicalizing Uighurs?" European Parliament, 2014, http://www.europarl.europa.eu/EPRS/EPRS-AaG-538966-China-Assimilating-orradicalising-Uighurs-FINAL.pdf

"China, Kazakhstan to Bolster Economic, Industrial Capacity, China Daily, May 7, 2015, https://www.chinadaily.com.cn/world/2015xiattendwwii/201505/07/content_20650929_2.htm

"China, Kazakhstan, Sign 33 Deals Worth 23.6 Billion U.S. Dollars," Xinhuanet, March 23, 2015, http://www.xinhuanet.com/english/2015-03/27/c_134104187.htm

"China, Kyrgyzstan Sign Joint Statement on Enhancing Co-op, Friendship," Embassy of the People's Republic of China in the United States of America, August 15, 2007, http://www.china-embassy.org/eng//xnyfgk/t351968.htm

"China and Russia Issue a Joint Statement, Declaring the Trend of the Boundary Line Between the Two Countries Has Been Completely Determined," Ministry of Foreign Affairs of the People's Republic of China, October 14, 2004, http://www.fmprc.gov.cn/eng/wjdt/2649/t165266.htm

"China Freight Train Arrives in Tehran, Six More Planed by Yearend," Financial Tribune, October 2, 2017, https://financialtribune.com/articles/economy-domesticeconomy/73300/china-freight-train-arrives-in-tehran-six-more-planned-by

"China Lends \$300 mn to Build Strategic Road in Kyrgyzstan," Daily Mail, June 16, 2015, http://www.dailymail.co.uk/wires/afp/article-3126461/China-lends-300-mn-buildstrategic-road-Kyrgyzstan.html

"China to Help Build a Second Tunnel at Kamchik Pass," The Tashkent Times, May 16, 2017, http://tashkenttimes.uz/economy/930-china-to-help-build-second-tunnel-atkamchik-pass

"China to Provide Tens of Thousands of Scholarships, Training Opportunities for Arab Nations: Xi," Xinhua News, January 21, 2016, http://news.xinhuanet.com/english/201601/21/c_135033115.htm

"China Voice: Quality of Life Key to Xinjiang Unity," Xinhua News, May 6, 2014, http://news.xinhuanet.com/english/indepth/2014-05/06/c_133314387.htm

"China will not "Export" Chinese Model: Xi," Xinhuanet, December 1, 2017, http://www.xinhuanet.com/english/2017-12/01/c_136793674.htm

"China's National Defense in 2002," Information Office of the State Council, 2002, http://www.china.org.cn/e-white/20021209/VI.htm\#2

"China's Party System is Great Contribution to Political Civilization," Xinhuanet, March 5, 2018, http://www.xinhuanet.com/english/2018-03/05/c_137015955.htm 
"China's Xi Strikes Conciliatory Note, Broadens Diplomatic Focus," Reuters, November 30, 2014, https://www.reuters.com/article/us-china-southchinasea/chinas-xi-strikesconciliatory-note-broadens-diplomatic-focus-idUSKCNOJE04J20141130

"China's Xi Urges State Media to Boost Global Influence," Reuters, February 19, 2016, https://www.reuters.com/article/us-china-media/chinas-xi-urges-state-media-to-boostglobal-influence-idUSKCNOVS1IF

“China's Xinjiang Seals Pakistan Ties with \$2 Billion in Deals," Reuters, April 7, 2016, https://www.reuters.com/article/us-china-pakistan/chinas-xinjiang-seals-pakistan-tieswith-2-billion-in-deals-idUSKCNOX507K

"China-Kazakhstan Border Co-Operation in Xinjiang," Hong Kong Trade Development Council, March 15, 2016, http://hkmb.hktdc.com/en/1X0A5JIX/hktdc-research/ChinaKazakhstan-Border-Co-operation-in-Xinjiang

"China-Kyrgyzstan-Uzbekistan Highway Opens to Traffic," Yidaiyilu, February 27, 2018, https://eng.yidaiyilu.gov.cn/qwyw/rdxw/49135.htm

"China-Kyrgyzstan-Uzbekistan Highway to Open to Traffic on Feb." Yidaiyilu, February 24, 2018, https://eng.yidaiyilu.gov.cn/qwyw/rdxw/48721.htm

"China-Pakistan Relations," Ministry of Foreign Affairs of the People's Republic of China, November 14, 2006, fmprc.gov.cn

"Chinese, Uzbek Leader Hail Inauguration of Central Asia's Longest Railway Tunnel," Xinhuanet, June 23, 2016, http://www.xinhuanet.com/english/201606/23/c_135458470.htm

"Chinese Companies Buy Stake in Dry Port in Kazakhstan," China Daily, May 15, 2017, http://www.chinadaily.com.cn/business/2017-05/15/content_29355527.htm

"Chinese Premier Leaves for Central Asia," United Press International, 1994, http://www.upi.com/Archives/1994/04/18/Chinese-premier-leaves-for-CentralAsia/5364766641600/

"Chinese and Soviet Statements on the Frontier Question," Keesing's Record of World Events 15, 1969, http://web.stanford.edu/group/tomzgroup/pmwiki/uploads/0349-196911-K-c-EYJ.pdf

"Circular of the State Council's General Office on the Distribution of "Suggestions on the Implementation of Policies and Measures Pertaining to the Development of the Western Region" Submitted by the Western Region Development Office of the State Council," The State Council of the People's Republic of China, September 29, 2001, https://www.tid.gov.hk/english/trade_relations/files/lawe.pdf 
"CNPC and KMZ to Double Crude Oil Pipeline from Kazakhstan to China," 2blst Consulting, April 21, 2013, https://www.2b1stconsulting.com/cnpc-and-kmz-to-doublecrude-oil-pipeline-from-kazakhstan-to-china/

"CNPC: Turkmenistan Gas Arrives at Guangdong," LNG World News, November 25, 2011, https://www.lngworldnews.com/cnpc-turkmenistan-gas-arrives-at-guangdong/ "Commentary: Silk Road Fund's $1^{\text {st }}$ Investment Makes China's Words into Practice," Xinhuanet, April 21, 2015, http://www.xinhuanet.com/english/201504/21/c_134170737.htm

"Commissioning of Dushanbe-2 Combined Heat and Power Plant," President of the Republic of Tajikistan, August 12, 2016, http://www.president.tj/en/node/13645

"Concept of Cooperation between SCO Member States in Combating Terrorism, Separatism, and Extremism," in Counter-Terrorism and Human Rights: The Impact of the Shanghai Cooperation Organization (Human Rights Watch in China, 2011), p. 166171

"Constitutional Law of Turkmenistan on Permanent Neutrality of Turkmenistan," Refworld, January 7, 1996, http://www.refworld.org/docid/405ab3d14.html

"CPEC Energy Projects," CPEC China Pakistan Economic Corridor, http://cpec.gov.pk/ "CPEC Infrastructure Projects," CPEC China Pakistan Economic Corridor, http://cpec.gov.pk/progress-update

"Decision of the Central Committee of the Communist Party of China on some Major Issues Concerning Comprehensively Deepening the Reform," USC US-China Institute, November 12, 2013, https://china.usc.edu/decision-central-committee-communist-partychina-some-major-issues-concerning-comprehensively

"Declaration of Shanghai Cooperation Organization," Embassy of the People's Republic of China in the Republic of Turkey, June 15, 2001, http://www.fmprc.gov.cn/ce/cetur/eng/zt/shhzzz/t162011.htm

"Declaration on the Establishment of the Shanghai Cooperation Organization," The Shanghai Cooperation Organization, June 15, 2001, http://eng.sectsco.org/documents/ "Delineation and Demarcation of State Border," Ministry of foreign Affairs Republic of Kazakhstan, 1998, http://mfa.gov.kz/en/content-view/delimitatsiya-i-demarkatsiyagosudarstvennoj-granitsy

"Deng says his Open-Door Policies Will Not Change: Hails 'Great Wall of Iron and Steel,"” Los Angeles Times, June 9, 1989, http://articles.latimes.com/1989-0609/news/mn-1828_1_deng-xiaoping-men-square-china-s-great-wall 
"Devastating Blows: Religious Repression of Uighurs in Xinjiang," Human Rights Watch, April 11, 2005, https://www.hrw.org/report/2005/04/11/devastatingblows/religious-repression-uighurs-xinjiang

"Development Strategy of the Shanghai Cooperation Organization Until 2025," The Shanghai Cooperation Organization, 2015, http://eng.sectsco.org/documents/

“'East Turkestan' Terrorist Forces Cannot Get Away With Impunity," Information Office of State Council, January 21, 2002, http://www.china.org.cn/english/2002/Jan/25582.htm

"Eastern and Western Routes of CPEC to be Completed by 2019," Pakistan Today, June 29, 2017, https://www.pakistantoday.com.pk/2017/06/29/eastern-and-western-routes-ofcpec-to-be-completed-by-2019/

"Establishment, Development and Role of the Xinjiang Production and Construction Corps," Information Office of the State Council of the People's Republic of China, 2003, http://www.china.org.cn/e-white/20030526/index.htm

"Fact Sheet: The New Eurasian Land Bridge," Geopolitical Monitor, February 7, 2018, https://www.geopoliticalmonitor.com/fact-sheet-the-new-eurasian-land-bridge/

"Feature: China-Aided Highway Changes Life of Pakistanis," Xinhuanet, April 20, 2015, http://www.xinhuanet.com/english/2015-04/20/c_134165479.htm

"Firms Discuss Cross-border Gas Pipeline," China Daily, August 25, 2004, http://www.chinadaily.com.cn/english/doc/2004-08/25/content_368622.htm

"First Freight Train from China Arrives in Iran in 'Silk Road' Boost," Reuters, February 16, 2016, https://www.reuters.com/article/us-china-iran-railway/first-freight-train-fromchina-arrives-in-iran-in-silk-road-boost-media-idUSKCNOVP0W8

"Flow of Natural Gas from Central Asia," China National Petroleum Corporation, 2016, http://www.cnpc.com.cn/en/FlowofnaturalgasfromCentralAsia/FlowofnaturalgasfromCen tralAsia2.shtml

"Foreign Minister Wang Yi Meets the Press," Ministry of Foreign Affairs of the People's Republic of China, March 8, 2015, http://www.fmprc.gov.cn/mfa_eng/zxxx_662805/t1243662.shtml

"Foreign Minister Wang Yi Meets the Press," Ministry of Foreign Affairs of the People's Republic of China, March 8, 2014,

http://www.fmprc.gov.cn/mfa_eng/wjb_663304/wjbz_663308/2461_663310/t1135385.sh tml

"Full Text: Report on China's Economic, Social Development Plan," Xinhuanet, March 17, 2017, http://www.xinhuanet.com/english/china/2017-03/17/c_136137416_3.htm 
"Full Text of Hu Jintao's Report at the $18^{\text {th }}$ Congress," Embassy of the People's Republic of China in the United States of America, November 27, 2011, http://www.chinaembassy.org/eng/zt/18th_CPC_National_Congress_Eng/t992917.htm

"Full Text of Joint Statement on Comprehensive Strategic Partnership Between I.R. Iran, P.R. China," President of the Islamic Republic of Iran, January 23, 2016, http://www.president.ir/en/91435

"Fund History," Silk Road Fund, http://www.silkroadfund.com.cn/enweb/23775/23778/index.html

"Future Linked to CPEC, PM Tells Turkmen President," Dawn, November 26, 2016, https://www.dawn.com/news/1298708

"Galkynysh Gas Field," Hydrocarbons-Technology, http://www.hydrocarbonstechnology.com/projects/galkynysh-gas-field-turkmenistan/

"Gap Seen Between Coastal, Nationality Regions," Lien Ho Pao, Hong Kong, November 7, 1994, FBIS-CHI-94-229, November 24, 1994

"Gwadar's Fact Sheet," Gwadar International, http://www.gwadarinternational.com/facts.html

"Gwadar Port to be Fully Operational in Three to Four years - Pakistan Envoy to China," Gulf News, August 22, 2017, http://gulfnews.com/news/asia/pakistan/gwadar-port-to-befully-operational-in-three-to-four-years-pakistan-envoy-to-china-1.2078434

"History," Kazakhstan-China Pipeline LLC, 2016, http://www.kcp.kz/company/histor "History of Development of SCO," China Daily, June 12, 2006, http://www.chinadaily.com.cn/china/2006-06/12/content_6020347.htm

"Hu Jintao's Report at $17^{\text {th }}$ Party Congress," China Daily, October 25, 2007, http://www.chinadaily.com.cn/china/2007-10/25/content_6225092_7.htm

"Introduction to the Implementation of the Great Western Development Strategy in China," Ministry of Environmental Protection of the People's Republic of China, November 2, 2000, http://english.sepa.gov.cn/Events/Special_Topics/AGM_1/2000agm/leaderspeech2000/2 01605/t20160524_345016.shtml

"Iran," CIA World Factbook, 2017, https://www.cia.gov/library/publications/the-worldfactbook/geos/ir.html

"Iran, China, Sign 17 Cooperation Agreements," Islamic Republic News Agency, January 23, 2016, http://www.irna.ir/en/News/81931797 
"Iran, China Plan for 25-Year Strategic Partnership," Iran Daily, January 23, 2016, http://www.iran-daily.com/News/135531.html

"Iran and China Sign 17 Agreements at Meeting of Rouhani and Xi in Tehran," Agencia EFE, January 23, 2016, https://www.efe.com/efe/english/business/iran-and-china-sign17-agreements-at-meeting-of-rouhani-xi-in-tehran/50000265-2819088

"Islamic Republic of Pakistan National Motorway M-4 (Shorkot-Khanewal Section)," Asian Infrastructure Investment Bank, June 6, 2016, https://www.aiib.org/en/projects/approved/2016/_download/pakistan-nationalmotorway/document/approved_project_document_pakistan_national_motorway.pdf

"Islamic Republic of Pakistan Tarbela 5 Hydropower Extension Project," Asian Infrastructure Investment Bank, December 9, 2016, https://www.aiib.org/en/projects/approved/2016/_download/pakistan-tarbela5/approved_project_document_tarbela_5_hydropower_extension.pdf

“Jiang: Perfecting 'Shanghai Five' Mechanism,” People's Daily, July 5, 2000, http://en.people.cn/english/200007/05/eng20000705_44747.html

"Joint Communique of Meeting of Council Heads of SCO Members," Ministry of Foreign affairs of the People's Republic of China, August 23, 2007, http://www.fmprc.gov.cn/mfa_eng/wjdt_665385/2649_665393/t355665.shtml

“Joint Comprehensive Plan of Action," U.S. Department of State, https://www.state.gov/e/eb/tfs/spi/iran/jcpoa/

"Joint Statement by the Heads of State of the Republic of Kazakhstan, the People's Republic of China, the Kyrgyz Republic, the Russian Federation, the Republic of Tajikistan, the Republic of Uzbekistan," The Shanghai Cooperation Organization, June 14, 2001, http://eng.sectsco.org/documents/

“Kazakh Leader Says \$23 Billion in Deals Agreed with China," Reuters, September 1, 2015, https://www.reuters.com/article/kazakhstan-china/kazakh-leader-says-23-billionin-economic-deals-agreed-with-china-idUSL5N1172H620150901

"Kazakhstan," CIA World Factbook, February 22, 2018, https://www.cia.gov/library/publications/the-world-factbook/geos/kz.html

"Kazakhstan Gets Sea Access Using Chinese Logistics Centres," The Astana Times, August 2017, 2017, https://astanatimes.com/2017/08/kazakhstan-gets-sea-access-usingchinese-logistics-centres/

"Kazakhstan Shows Willingness to Join CPEC Project," The News, August 26, 2015, https://www.thenews.com.pk/print/14270-kazakhstan-shows-willingness-to-join-cpecproject 
"Kazakhstan-China Crude Oil Pipeline," Hydrocarbons-Technology, http://www.hydrocarbons-technology.com/projects/kazakhstan-china-crude-oil-pipeline/

"Kyrgyzstan Hails 'Historic' China-Financed Power Line," The Strait Times, August 28, 2015, http://www.straitstimes.com/asia/kyrgyzstan-hails-historic-china-financed-powerline

"Letter, Khrushchev to the Central Committee of the Socialist Unity Party of Germany, Regarding Soviet Specialists in China," The Wilson Center Digital Archive, July 18, 1960, http://digitalarchive.wilsoncenter.org/document/116831

"Li Keqiang: Building the China-Pakistan Economic Corridor Flagship Project," Ministry of Foreign Affairs of the People's Republic of China, November 8, 2014, http://www.fmprc.gov.cn/mfa_eng/topics_665678/ytjhzzdrsrcldrfzshyjxghd/t1209089.sht $\mathrm{ml}$

"Li Keqiang: China-Pakistan Ties 'Unbreakable,' Economic Corridor Planned," Global Times, May 23, 2013, https://web.archive.org/web/20140312032536/http://gbtimes.com/china/li-keqiang-chinapakistan-ties-unbreakable-economic-corridor-planned

"Meeting between Mikhail Gorbachev and Deng Xiaoping (Excerpts)," The Wilson Center Digital Archive, May 16, 1989, http://digitalarchive.wilsoncenter.org/document/116536

"Military and Law Enforcement Cooperation Between Member States of the Shanghai Cooperation Organization," in Counter-Terrorism and Human Rights: The Impact of the Shanghai Cooperation Organization (Human Rights Watch in China, 2011), p. 331-336

"Modernization of Bishkek Thermal Power Plant Completes in Kyrgyzstan," Kabar, August 30, 2017, http://kabar.kg/eng/news/modernization-of-bishkek-thermal-powerplant-completes-in-kyrgyzstan/

"National Security Strategy of the United States of America," The White House, 2017, https://www.whitehouse.gov/wp-content/uploads/2017/12/NSS-Final-12-18-20170905.pdf

"National Work Conference of the Central Committee of the Chinese Communist Party and the Sixth National Commendation Meeting for National Unity and Progress held in Beijing," Xinhua News, September 29, 2014, http://news.xinhuanet.com/politics/201409/29/c_1112683008.htm

"New Eurasian Land Bridge," China.org, April 19, 2017, http://www.china.org.cn/english/china_key_words/2017-04/19/content_40651850.htm 
"New Five-Year Plan Brings Hope to China's West," State Council of the People's Republic of China, December 27, 2016, http://english.gov.cn/premier/news/2016/12/27/content_281475526349906.htm

"Nineteenth Congress: China's Smart China Program Affects the World," Renmin, October 24, 2017, http://paper.people.com.cn/rmrb/html/2017-

10/24/nw.D110000renmrb_20171024_6-01.htm

"Note, The Soviet Embassy in Beijing to the Ministry of Foreign Affairs of the People's Republic of China," The Wilson Center Digital Archive, July 18, 1960, http://digitalarchive.wilsoncenter.org/document/117052

"Overall Plan of Western Region Development During the Tenth Five-Year Plan Period," China.org, 2002, http://www.china.com.cn/market/hwc/400823.htm

"Overview," Silk Road Fund, http://www.silkroadfund.com.cn/enweb/23775/23778/index.html

"Pakistan," CIA World Factbook, 2017, https://www.cia.gov/library/publications/theworld-factbook/geos/pk.html

"People's Republic of China: Uighurs Fleeting Persecution as China Wages its War on Terror," Amnesty International, July 6, 2004, https://www.amnesty.org/en/documents/ASA17/021/2004/en/

"PRC: 'Text' of PRC-Russia Statement Released," Beijing Xinhua Domestic Service, April 25

1996, FBIS-CHI-96-081, April 25, 1996

"President in the Meeting of High-Ranking Delegations of Iran and China: A New Chapter in Tehran-Beijing Ties Started/25-Year Comprehensive, Executive Document Soon," President of the Islamic Republic of Iran, January 23, 2016, http://president.ir/en/91443

"President Xi's Article Published on Pakistani Paper," China Daily, April 19, 2015, http://www.chinadaily.com.cn/world/2015xivisitpse/2015-04/19/content_20474266.htm

"President Xi Jinping Delivers Important Speech and Proposes to Build a Silk Road Economic Belt with Central Asian Countries," Ministry of Foreign Affairs of the People's Republic of China, September 7, 2013,

http://www.fmprc.gov.cn/mfa_eng/topics_665678/xjpfwzysiesgjtfhshzzfh_665686/t1076 334.shtml

"Rich Province, Poor Province," The Economist, October 1, 2016, https://www.economist.com/news/china/21707964-government-struggling-spreadwealth-more-evenly-rich-province-poor-province 
"Russia,” CIA World Factbook, 2017, https://www.cia.gov/library/publications/theworld-factbook/geos/rs.html

"Russian-Chinese Joint Declaration on a Multipolar World and the Establishment of a New International Order," United Nations General Assembly A/52/153-S1997/384, April 23, 1997, http://www.un.org/documents/ga/docs/52/plenary/a52-153.htm

"Ruzlan Izimov: China and Turkmenistan - a Regional Dimension," Central Asia Bureau for Analytical Reporting, August 29, 2016, http://cabar.asia/en/ruslan-izimov-china-andturkmenistan-a-regional-dimension/

"Senate Secretariat: Questions for Oral Answers and Their Replies," Senate of Pakistan, October 23, 2014, http://www.senate.gov.pk/uploads/documents/questions/1414066312_704.pdf

"Shanghai Cooperation Organization: A Vehicle for Human Rights Violation," International Federation for Human Rights, 2012, p. 4-46, https://www.fidh.org/IMG/pdf/sco_report.pdf

"Shanghai Declaration of the Fifth Anniversary of the Shanghai Cooperation Organization," The Shanghai Cooperation Organization, 2006, http://eng.sectsco.org/documents/

"Song Hanliang Blames 'Separatists,"” Hong Kong AFP, April 25, 1990, FBIS-CHI-90080, April 25, 1990

"Song Hanliang Gives Xinjiang CPC Report," Urumqi Xinjiang Ribao, March 23, 1991, FBIS-CHI-91-071, April 12, 1991

"Soviet Report to East German Leadership on Sino-Soviet Border Clashes," The Wilson Center Digital Archive, March 2, 1969, http://digitalarchive.wilsoncenter.org/document/116975

"Speech by Chinese President Xi Jinping to Indonesian Parliament," ASEAN-China Centre, October 3, 2013, http://www.asean-china-center.org/english/2013-

10/03/c_133062675.htm

"Spokesperson's remarks on the Death of Hasan Mahsum, Head of the "East Turkistan Islamic Movement."' Permanent Mission of the People's Republic of China to the UN, December 24, 2003, http://www.fmprc.gov.cn/ce/ceun/eng/fyrth/t57039.htm

"Spotlight: "Shanghai Five": A Paradigm Mechanism for Peace, Development at Border Areas," Xinhuanet, April 14, 2016, http://www.xinhuanet.com/english/201604/14/c_135279213.htm 
"Stability in Pakistan Integral to China's Development: Ambassador," The Nation, March 17, 2018, https://nation.com.pk/17-Mar-2018/stability-in-pakistan-integral-to-china-sdevelopment-ambassador

"Statement by the Ministry of Foreign Affairs of the Republic of Kazakhstan on the Situation on Southeastern Ukraine," Kazinform, March 3, 2014, http://www.inform.kz/en/statement-of-the-foreign-ministry-of-the-republic-ofkazakhstan-on-the-situation-in-ukraine_a2635749

"Statement of the Government of the People's Republic of China," Peking Review 12(22), May 24, 1969, p. 3-9

"Statement of the Information Agency "Jahon" on the Events in Ukraine," Ministry of Foreign Affairs of the Republic of Uzbekistan, March 4, 2014, http://www.mfa.uz/en/press/statements/2014/03/6329/

“Tajikistan," International Hydropower Association, 2015, https://www.hydropower.org/country-profiles/tajikistan

“Tajikistan," OpenNet Initiative, December 1, 2010, https://opennet.net/research/profiles/tajikistan

“Tajik Energy Minister Confirms Work resumed on Central Asia-China Gas Pipeline," bne IntelliNews, February 2, 2018, http://www.intellinews.com/tajik-energy-ministerconfirms-work-resumed-on-central-asia-china-gas-pipeline-136162/

“Tajikistan Seeks to Commission ${ }^{\text {st }}$ Stage in Danghara Oil Refinery in 2019," Trend News Agency, January 22, 2018, https://en.trend.az/casia/tajikistan/2850879.html

"Tajikistan," Nurek Hydropower Rehabilitation Project, Phase I," Asian Infrastructure Investment Bank, June 15, 2017, https://www.aiib.org/en/projects/approved/2017/nurekhydropower-rehabilitation-project.html

"Tashkent Declaration by Heads of Member States of the Shanghai Cooperation Organization," The Shanghai Cooperation Organization, 2004, http://eng.sectsco.org/documents/

“Tarim Desert Highway,” Baike Baidu, September 27, 2017, https://baike.baidu.com/item/\%E5\%A1\%94\%E9\%87\%8C\%E6\%9C\%A8\%E6\%B2\%99\% $\mathrm{E} 6 \% \mathrm{BC} \% \mathrm{~A} 0 \% \mathrm{E} 5 \% 85 \% \mathrm{AC} \% \mathrm{E} 8 \% \mathrm{~B} 7 \% \mathrm{AF}$ [In Mandarin]

“TCA: Kyrgyzstan, Tajikistan Greatly Depend on Migrant Labor," Kabar, May 28, 2017, http://kabar.kg/eng/news/tca-kyrgyzstan-tajikistan-greatly-dependent-on-migrant-labor/

"Tehran-Mashhad Railway Project Gets Off the Ground," Financial Tribune, December 20, 2017, https://financialtribune.com/articles/domestic-economy/78248/tehran-mashhadrailroad-project-gets-off-the-ground 
"Terrorist Activities Perpetrated by "East Turkestan" Organizations and their Links with Osama Bin Laden and the Taliban," Permanent Mission of the People's Republic of China to the UN, November 29, 2001, http://www.china-un.org/eng/zt/fk/t28937.htm

"The Astana Declaration of the Heads of State of the Shanghai Cooperation Organization," The Shanghai Cooperation Organization, 2017, http://eng.sectsco.org/documents/

“The Belt Road Initiative," Hong Kong Trade Development Council, September 13, 2017, http://china-trade-research.hktdc.com/business-news/article/The-Belt-and-RoadInitiative/The-Belt-and-Road-Initiative/obor/en/1/1X000000/1X0A36B7.htm

"The Conqueror of China's Wild West," Asia Sentinel, April 13, 2008, https://www.asiasentinel.com/politics/the-conqueror-of-chinas-wild-west/

“The 'Empty Chair' Policy," CVCE, 2016, https://www.cvce.eu/en/education/unitcontent/-/unit/02bb76df-d066-4c08-a58a-d4686a3e68ff/62cd6534-f1a9-442a-b6fbObab7c842180

"The Joint Statement of Participants of the Almaty Meeting - the Republic of Kazakhstan, People's Republic of China, the Kyrgyz Republic, the Russian Federation and the Republic of Tajikistan," CIS-Legislation, June 3, 1998, http://cislegislation.com/document.fwx?rgn=3881

"The Origin and Development of the Differences Between the Leadership of the CPSU and Ourselves: Comment on the Open Letter of the Central Committee of the CPSU," Foreign Language Press, 1963, https://www.marxists.org/subject/china/documents/polemic/cpsu.htm\#origin

"The Railway to Iran," South China Morning Post, http://multimedia.scmp.com/news/china/article/One-Belt-One-Road/iran.html

"The Shanghai Convention on Combating Terrorism, Separatism and Extremism," The Shanghai Cooperation Organization, June 15, 2001, http://eng.sectsco.org/documents/

"Three Highway Projects to Connect Pakistan with Tajikistan Approved," The News, November 14, 2015, https://www.thenews.com.pk/print/15662-three-highway-projectsto-connect-pakistan-with-tajikistan-approved

"Transcript of Foreign Minister Wang Yi's Interview with Belahodood of Al Jaazeera," Embassy of the People's Republic of China in the Republic of Indonesia, May 19, 2016, http://www.mfa.gov.cn/ce/ceindo/eng/xwdt/t1364778.htm

"Transcript: Xi Jinping's Speech at the Unveiling of the New Chinese Leadership," South China Morning Post, November 15, 2012, http://www.scmp.com/news/18th-partycongress/article/1083153/transcript-xi-jinpings-speech-unveiling-new-chinese 
“Tree Belt Built Across World's Longest Desert Highway,” People's Daily, May 8, 2001, http://www.china.org.cn/english/12349.htm

“Turkmenistan," CIA World Factbook, February 22, 2018, https://www.cia.gov/library/publications/the-world-factbook/geos/tx.html

"Turkmen in Gas Warning to Russia," BBC News, June 21, 2006, http://news.bbc.co.uk/2/hi/business/5101588.stm

"Ufa Declaration of the Heads of Member States of the Shanghai Cooperation Organization," The Shanghai Cooperation Organization, 2015, http://eng.sectsco.org/documents/

"USAID Trade Project: Analysis of Quadrilateral Traffic in Transit Agreement (QTTS)," USAID Trade Project, 2014, p. 4, http://pdf.usaid.gov/pdf_docs/PA00K24C.pdf

"Uzbekistan," CIA World Factbook, February 22, 2018, https://www.cia.gov/library/publications/the-world-factbook/geos/uz.html

"Uzbekistan and China Sign Agreements Worth \$22 Billion: 105 Documents on Gas, Energy Saving, Agriculture," Ferghana News, May 15, 2017,

http://enews.fergananews.com/news.php?id=3341\&mode=snews

"Uzbekistan Considering Becoming Part of CPEC," The Nation, December 25, 2016, https://nation.com.pk/25-Dec-2016/uzbekistan-considering-becoming-part-of-cpec

"Vision and Actions on Jointly Building Silk Road Economic Belt and $21{ }^{\text {st }}$ Century Maritime Road," National Development and Reform Commission of the People's Republic of China, March 28, 2015, http://en.ndrc.gov.cn/newsrelease/201503/t20150330_669367.html

"Vladimir Putin Took Part in a Summit of the Shanghai Five Heads of State," President of Russia, July 5, 2000, http://en.kremlin.ru/events/president/news/38289

"Wang Enmao Addresses 16th Xinjiang Party Session," Urumqi Xinjiang Ribao, March 14, 1991, FBIS-CHI-91-050, March 14, 1991

"Wang Yi Talks about General Goal of Major Country Diplomacy with Chinese Characteristics in New Era: To Promote the Building of a Community with Shared Future for Mankind," Ministry of Foreign Affairs of the People's Republic of China, October 19, 2017, http://www.fmprc.gov.cn/mfa_eng/zxxx_662805/t1503758.shtml

"West-East Gas Pipeline Project," Hydrocarbons-Technology, https://www.hydrocarbons-technology.com/projects/west-east/

“West-East Gas Pipeline III,” Wood Mackenzie, November 1, 2017, https://www.woodmac.com/reports/upstream-oil-and-gas-west-east-gas-pipeline-iii37188828 
"West-East Gas Pipeline Project Begins Commercial Operations," PetroChina Company Limited, December 30, 2004, http://www.petrochina.com.cn/enpetrochina/xwxx/201404/0163d5084c414ee89beb8bed6 0bb961c.shtml

"Who will Pay for Asia's $\$ 8$ Trillion Infrastructure Gap," Asian Development Bank, September 30, 2013, https://www.adb.org/news/infographics/who-will-pay-asias-8trillion-infrastructure-gap

"Wild West Rail Link to Open up Trade, Tourism to Muslim Outposts," South China Morning Post, May 15, 1999, http://www.scmp.com/article/282092/wild-west-rail-linkopen-trade-tourism-muslim-outposts

"Work Resumes on Troubled Turkmenistan-China Pipeline," Oil Price, February 4, 2018, https://oilprice.com/Geopolitics/Asia/Work-Resumes-On-Troubled-TurkmenistanChina-Pipeline.html

"Xi's Trip to Promote Win-Win Cooperation," CCTV English, August 28, 2013, http://english.cntv.cn/20130828/105024.shtml

"Xi Jinping Delivers Speech at SCO Summit, and Raises Four-Point Proposal," Ministry of the People's Republic of China, September 13, 2013, http://www.fmprc.gov.cn/mfa_eng/topics_665678/xjpfwzysiesgjtfhshzzfh_665686/t1077 762.shtml

"Xi Jinping Holds Talks with President Gurbanguly Berdymukhamedov of Turkmenistan, Two Heads of State Announce Establishment of China-Turkmenistan Strategic Partnership," Embassy of the People's Republic of China in the United States of America, September 4, 2013, http://www.china-

embassy.org/eng/zt/xijinpingfangwenzhongyawuguobingchuxiG20fenghui/t1073474.htm "Xi Jinping Meets with Prime Minister Nawaz Sharif of Pakistan," Ministry of Foreign Affairs of the People's Republic of China, November 8, 2014, http://www.fmprc.gov.cn/mfa_eng/topics_665678/ytjhzzdrsrcldrfzshyjxghd/t1209091.sht $\mathrm{ml}$

"Xi Jinping Meets with Representatives from Various Countries Attending the Signing Ceremony of the MOU on Preparing to Establish the Asian Infrastructure Investment Bank," Ministry of Foreign Affairs of the people's Republic of China, October 24, 2014, http://www.fmprc.gov.cn/mfa_eng/zxxx_662805/t1204639.shtml

"Xi Jinping Signs Deals Worth US\$15b in Uzbekistan," South China Morning Post, September 9, 2013, http://www.scmp.com/news/china/article/1307127/china-uzbekistansign-agreements-worth-us15-billion

"Xinhua Insight: Poverty Relief High on China's Policy Agenda," Xinhuanet, July 22, 2016, http://www.xinhuanet.com/english/2016-07/22/c_135533434.htm 
"Xinjiang Governor Explains Open Door Program," China Daily (Business Weekly), July 10, 1989, FBIS-CHI-89-133, July 13, 1989

"Xinjiang Unveils Route Map for Bid to Become Key Belt and Road Transportation Hub," Hong Kong Trade Development Council, July 17, 2017, http://china-traderesearch.hktdc.com/business-news/article/The-Belt-and-Road-Initiative/XinjiangUnveils-Route-Map-For-Bid-to-Become-Key-Belt-and-Road-Transportation-Hub-20162030/obor/en/1/1X000000/1X0ABJVK.htm

"Xinjiang's Construction Plan for Development of a Transport Center on the Silk Road Economic Belt from 2016-2030," Yidaiyilu, August 30, 2017, https://eng.yidaiyilu.gov.cn/zchj/dfgg/25503.htm

"Xinjiang's Land Ports \& Border Trade," China.org, December 15, 2017, http://www.china.org.cn/english/features/Xinjiang/114777.htm

"XJTU Initiated the University Alliance of the New Silk Road," Xi'an Jiaotong University, May 22, 2015, http://en.xjtu.edu.cn/info/1043/1706.htm

Abdullaev, Iskandar, Giordano, Mark, and Rasulov, Aziz, "Cotton in Uzbekistan: Water and Welfare," Center for Development Research University of Bonn, p. 112-128, https://www.zef.de/uploads/tx_zefportal/Publications/83a8_Abdullaev\%20100807.pdf

Adler, Emanuel and Barnett, Michael, "Security Communities in Theoretical Perspective," in Security Communities, eds. Emanuel Adler and Michael Barnett (Cambridge: Cambridge University Press, 1998)

Adler, Emanuel, "Imagined (Security) Communities: Cognitive Regions in International Relations," Millennium: Journal of International Relations 26(2), 1997, p. 249-277

Adler, Emanuel and Barnett, Michael, "Governing Anarchy: A Research Agenda for the Study of Security Communities," Ethics and International Affairs 10, 1996, p. 63-94

Ahmed, Fawad, "China Raises CPEC investment from \$55 Billion to \$62 Billion Pakistan," CPEC Bulletin, April 17, 2017, https://cpecbulletin.com/2017/04/17/chinaraises-cpec-investment-from-55-billion-to-62billion-pakistan/

Akihiro, Iwashita, "An Inquiry for New Thinking on the Border Dispute: Backgrounds of "Historic Success" for the Sino-Russian Negotiations," in Siberia and the Russian Far East in the $21^{\text {st }}$ Century: Partners in the "Community of Asia", ed. Iwashita Akihiro (Sapporo: Slavic Research Center, Hokkaido University, 2005), p. 95-114

Akihiro, Iwashita, "The Shanghai Cooperation Organization and Its Implications for Eurasian Security: A New Dimension of 'Partnership' after the Post-Cold War Period," in Slavic Eurasia's Integration into the World Economy and Community, eds. Tabata Shinichiro and Iwashita Akihiro (Sapporo: Slavic Research Center, Hokkaido University, 2004), p. 259-281 
Akihiro, Iwashita, A 4,000 Kilometer Journey Along the Sino-Russian Border (Sapporo: Slavic Research Center, Hokkaido University, 2004)

Alimov, Rashid, "The Role of the Shanghai Cooperation Organization in Counteracting Threats to Peace and Stability," UN Chronicle LIV(3), 2017, https://unchronicle.un.org/article/role-shanghai-cooperation-organization-counteractingthreats-peace-and-security

Allison, Roy, "Regionalism, Regional Structures and Security Management in Central Asia," International Affairs 80(3), 2004, p. 463-483

An, Tai-Sung, The Sino-Soviet Territorial Dispute (Philadelphia: The Westminster Press, 1973)

Anderson, Benedict, Imagined Communities: Reflections on the Origins and Spread of Nationalism (London: Verso, 1983)

Andrews-Speed, Phillip, "China's Energy Policymaking Process and their Consequences," in China's Energy Crossroads: Forging a New Energy and Environmental Balance, eds. Phillip Andrews-Speed, Mikkal E. Herberg, Li Zhidong, and Benjamin A. Shobert, NBR Special Report 47, 2014, p. 1-18

Aris, Stephen, "Shanghai Cooperation Organization: Mapping Multilateralism in Transition No.2," International Peace Institute, 2013, https://www.ipinst.org/wpcontent/uploads/publications/ipi_e_pub_shanghai_cooperation.pdf

Aris, Stephen, "The Shanghai Cooperation Organization: 'Tackling the Three Evils.' A Regional Response to Non-Traditional Security Challenges or an Anti-Western Bloc," Europe-Asia Studies 61(3), 2009, p. 457-482

Arnold, Martin, Financial Times, February 26, 2018, https://www.ft.com/content/d9fbf8a6-197d-11e8-aaca-4574d7dabfb6

Bachman, David, "Making Xinjiang Safe for the Han? Contradiction and Ironies of Chinese Governance in China's Northwest," in Governing China's Multiethnic Frontiers, ed. Morris Rossabi (Seattle: University of Washington Press, 2004), p. 155-185

Bailes, Alyson J.K.and Dunay, Pal, "The Shanghai Cooperation Organization as a Regional Security Institution," in The Shanghai Cooperation Organization, eds. Alyson J.K. Bailes, Pal Dunay, Pan Guang, and Mikhail Troitskiy (Stockholm: SIPRI Policy Paper 17, 2007), p. 1-29

Baloch, Shah Meer, "Why are Pakistanis Keen to Learn Chinese Language?" $D W$, November 21, 2017, http://www.dw.com/en/why-are-pakistanis-keen-to-learn-chineselanguage/a-41465711 
Barboza, David, "China Passes Japan as Second-Largest Economy," The New York Times, August 15, 2010,

http://www.nytimes.com/2010/08/16/business/global/16yuan.html?pagewanted=all

Barker, Thomas, "The Real Source of China's Soft Power," The Diplomat, November 18, 2017, https://thediplomat.com/2017/11/the-real-source-of-chinas-soft-power/

Batyrov, Azamat, "Kazakhstan Will Upgrade Railways, Thanks to Deals with General Electric," Caspian News, January 22, 2018, https://caspiannews.com/news-

detail/kazakhstan-will-upgrade-railways-thanks-to-deals-with-general-electric-2018-121-54/

Beschloss, Michael R., The Crisis Years: Kennedy and Khrushchev, 1960-1963 (New York: HarperCollins Publishers, 1991)

Becquelin, Nicolas, "Staged Development in Xinjiang," The China Quarterly 178, 2004, p. $358-378$

Becquelin, Nicolas, "Xinjiang in the Nineties," The China Journal 44, 2000, p. 65-90

Bozorgmehr, Najmeh, "First Freight Trains from China Arrive in Tehran," Financial

Times, May 9, 2016, https://www.ft.com/content/e964a78e-0bd8-11e6-9456-

444ab5211a2f

Bovington, Gardner, The Uyghurs: Strangers in their Own Land (New York: Columbia University Press, 2010)

Bradsher, Keith, "Hauling Treasure Along the Silk Road," The New York Times, July 20, 2013, http://www.nytimes.com/2013/07/21/business/global/hauling-new-treasure-alongthe-silk-road.html?pagewanted=all

Bracken, Andrew, Hajj, Christina, Hartman, Kristy, and Sivalingam, Shivan, "China's Quest for Energy Security: Redefining and Driving Foreign Aid: An Analysis of China's Involvement in Central Asia and Africa," Policy Reports, Ford School University of Michigan, 2012, http://sites.fordschool.umich.edu/china-policy/files/2012/09/oil-and-aidCHINA-FINAL-PAPER.pdf

Brauchli, Marcus W., "China's Hinterland Seeks Coast's Progress: Ethnic and Environmental Issues Slow the Advance," The Wall Street Journal, November 3, 1993, https://search-proquest-com.ezproxy.fiu.edu/docview/398380735?accountid=10901

Brauer, Birgit, "Crisis in Crimea: Will Kazakhstan be Next?" Eurasia Daily Monitor 11(48), March 13, 2014, https://jamestown.org/program/crisis-in-crimea-will-kazakhstanbe-next/ 
Brautigam, Deborah and Gallagher, Kevin P., "Bartering Globalization: China's Commodity-backed Finance in Africa and Latin America," Global Policy 5(3), 2014, p. 346-352

Burdman, Mary, "'Shanghai Five' Summit Offers Eurasia New Strategic Outlook," Executive Intelligence Review 27(29), 2000, http://www.larouchepub.com/eiw/public/2000/eirv27n29-20000728/eirv27n29-

20000728_044-shanghai_five_summit_offers_eura.pdf

Burgess, Michael, "Federalism," in European Integration Theory $2^{\text {nd }}$ Edition, eds. Antje Wiener and Thomas Diez (Oxford, Oxford University Press, 2009), p. 25-44

Burgess, Michael, Federalism and European Union: The Building of Europe, 1950-2000 (New York: Routledge, 2000)

Burgess, Michael, Federalism and European Union: Political Idea, Influences and Strategies in the European Community, 1972-1987 (New York: Routledge, 1991)

Buzan, Barry and Waever, Ole, Regions and Powers: The Structure of International Security (Cambridge: Cambridge University press, 2003)

Buzan, Barry, Waever, Ole and de Wilde, Jaap, Security: A New Framework for Analysis (Boulder: Lynne Rienner Publichers Inc., 1998)

Buzan, Barry, People, States, and Fear: An Agenda for International Security Studies in the Post-Cold War Era $2^{\text {nd }}$ Edition (New York: Harvester Wheatsheaf, 1991)

Cai, Peter, "Understanding China's Belt and Road Initiative," Lowy Institute, March 22, 2017, https://www.lowyinstitute.org/publications/understanding-belt-and-roadinitiative\#_edn19

Callahan, William A., "China's “Asia Dream”: The The Belt Road Initiative and the New Regional Order," Asian Journal of Comparative Politics 1(3), 2016, p. 226-243

Camba, Alvin, "Fact-Checking Critics of Chinese Aid," East Asia Forum, November 28, 2017, http://www.eastasiaforum.org/2017/11/28/fact-checking-critics-of-chinese-aid/

Cantori, Louis J. and Spiegel, Steven L., International Politics of Regions: A Comparative Approach (Englewood Cliffs: Prentice Hall, 1970)

Canuto, Otaviano and Halland, Havard, "Resource-Backed Investment Finance in Lead Developed Countries," The World Bank, September 23, 2013, http://blogs.worldbank.org/growth/resource-backed-investment-finance-least-developedcountries

Caponera, Dante, Principles of Water Law and Administration: National and International $2^{\text {nd }}$ Edition (Leiden: Taylor \& Francis/Balkema, 2007) 
Carlson, Allen, Unifying China, Integrating the with the World: Securing Chinese Sovereignty in the Reform Era (Stanford: Stanford University press, 2005)

Chan, Louis, "Kazakhstan: A Modern Silk Road Partner," Hong Kong Trade Development Council, January 26, 2016, http://hkmb.hktdc.com/en/1X0A50Y2/hktdcresearch/Kazakhstan-A-Modern-Silk-Road-Partner

Chan, Louis, "An Overview of Central Asian Markets on the Silk Road Economic Belt," Hong Kong Trade Development Council, November 15, 2015, http://hkmb.hktdc.com/en/1X0A4C4W/hktdc-research/An-Overview-of-Central-AsianMarkets-on-the-Silk-Road-Economic-Belt

Chang, Chun-shu, The Rise of the Chinese Empire: Volume II: Frontier, Immigration, \& Empire in Han China, 130B.C.-A.D. 157 (Ann Arbor: The University of Michigan Press, 2007)

Chen, Ping, Liu, Jun, Wei, Ran, Liu, Yong, "China's Logistic Development in Certain Key Regions," in Contemporary Logistics in China: Transformation and Revitalization, eds. Bing-lian Liu, Shao-ju Lee, Jian-hua Xiao, Long Wang, and Zhi-lun Jiao (New York: Springer, 2013), p. 47-104

Chen, Yao, "Kyrgyz Confucius Institutes-Cultural Envoys Between Kyrgyzstan, China," 24, October 20, 2014, https://24.kg/archive/en/bigtiraj/172754-news24.html/

Chen, Zhili, "A Successful Example of International Chinese Language Promotion and Chinese-Foreign Cultural Exchanges-to the $10^{\text {th }}$ Anniversary of the Confucius Institutes," Hanban News, February 5, 2015, http://english.hanban.org/article/201502/05/content_573650.htm

Cheng, Evelyn, "Kazakhstan Pushes for US Deals- Helped by China's Investments," CNBC, January 31, 2018, https://www.cnbc.com/2018/01/31/kazakhstan-pushes-for-usdeals--helped-by-chinas-investments.html

Chiang Kai-shek, China's Destiny \& Chinese Economic Theory (New York: Roy Publishers, 1947)

Chow, Daniel C.K., "Why China Established the Asia Infrastructure Investment Bank," Vanderbilt Journal of Transnational Law 59, 2016, p. 1255-1298

Christoffersen, Gaye, "Xinjiang and the Great Islamic Circle: The Impact of Transnational Forces on Chinese Regional Economic Planning," The China Quarterly 133, 1993, p. 130-151

Clarke, Michael, "The Belt and Road Initiative and China's Xinjiang Dilemma: "Connectivity" Versus Control?" The Central Asia-Caucasus Analyst, July 17, 2017, https://www.cacianalyst.org/publications/analytical-articles/item/13458-the-belt-and- 
road-initiative-and-china $\% \mathrm{E} 2 \% 80 \% 99$ s-xinjiang-

dilemma-\%E2\%80\%9Cconnectivity\%E2\%80\%9D-versus-control?.html

Clarke, Michael, "Why Xi Jinping's Belt and Road Rhetoric of Inclusion Rings Hollow among the Muslim Uyghurs of Xinjiang," South China Morning Post, June 7, 2017, http://www.scmp.com/comment/insight-opinion/article/2097229/why-xi-jinpings-beltand-road-rhetoric-inclusion-rings

Clarke, Michael, "China's Integration of Xinjiang with Central Asia: Securing a "Silk Road" to Great Power Status?" China and Eurasia Forum Quarterly 6(2), 2008, p. 89111

Clarke, Michael "China's 'War on Terror" in Xinjiang: Human Security and the Causes of Violent Uighur Separatism," Griffith Asia Institute: Regional Outlook Paper 11, 2007, p. $1-28$

Cong, Wang, "Free Trade Zone Links Consumers in China, Kazakhstan," Global Times, May 2, 2017, http://www.globaltimes.cn/content/1045034.shtml

Cooley, Alexander, "China's Changing Role in Central Asia and Implications for US Policy: From Trading Partner to Collective Goods Provider," U.S.-China Economic and Security Review Commission, March 18, 2015, http://www.uscc.gov/sites/default/files/Cooley\%20Testimony_3.18.15.pdf

Cooley, Alexander and Laruelle, Marlene, "The Changing Logic of Russian Strategy in Central Asia: From Privilege Sphere to Divide and Rule?” PONARS Eurasia 261, 2013, http://www.ponarseurasia.org/sites/default/files/policy-memos-pdf/Pepm_261_CooleyLaruelle_July\%202013.pdf

Cooley, Alexander, Great Games, Local Rules: The New Great Power Contest in Central Asia (Oxford: Oxford University Press, 2012)

Dash, Mike, "Khrushchev in Water Wings: On Mao, Humiliation and the Sino-Soviet Split," Smithsonian, May 4, 2012, https://www.smithsonianmag.com/history/khrushchevin-water-wings-on-mao-humiliation-and-the-sino-soviet-split-80852370/

Davidson, Christopher, Persian Gulf and Pacific Asia: From Indifference to Interdependence (New York: Columbia University Press, 2010)

Debreczeni, Gabor, "The New Eurasian Land Bridge: Opportunities for China, Europe, and Central Asia," The Public Sphere Journal, 2016, http://publicspherejournal.com/wpcontent/uploads/2016/02/02.eurasian_land_bridge.pdf

Deng, Xiaoping, Selected Works of Deng Xiaoping Volume 3 (Beijing: Beijing Foreign Language Press, 1994) 
Deutsch, Karl W., "Integration and Arms Control in the European Political Environment: A Summary Report," The American Political Science Review 60(2), 1966, p. 354-365

Deutsch, Karl W., Burrell, Sidney A., Kann, Robert A., and Lee Jr., Maurice, Political Community and the North Atlantic Area: International Organization in the Light of Historical Experience (Princeton: Princeton University Press, 1957)

Djanibekov, Nodir, Rudenko, Inna, Lamers, John P. A., and Bobojonov, Ihtiyor, "Pros and Cons of Cotton Production in Uzbekistan," in Food Policy for Development Countries: Food Production and Supply Policies, ed. Per Pinstrup-Andersen and Derrill D. Watson II (Ithaca: Cornell University Press, 2010), p. 1-13

Dmochowski, Tadeusz, "The Settlement of the Russian-Chinese Border Dispute," Polish Political Science Yearbook 44, 2015, p. 56-74

Donaldson, John A., "Regional Development Policy and Regional Inequality," in Handbook of the Politics of China, ed. David S.G. Goodman (Cheltenham: Edward Elgar Publishing, 2015), p. 187-204

Doolin, Dennis J., Territorial Claims and the Sino-Soviet Conflict: Documents and Analysis (Stanford: The Hoover Institution, 1965)

Dorraj, Manochehr and Currier, Carrier L., "Lubricated by Oil: Iran-China Relations in a Changing World," Middle East Policy Council 15(2), 2008, http://www.mepc.org/journal/middle-east-policy-archives/lubricated-oil-iran-chinarelations-changing-world?print

Downs, Erica, “China’s Development Bank's Oil Loans: Pursuing Policy - and Profit," China Economic Quarterly, 2011, p. 43-47

Duchatel, Mathieu, “The Terrorist Risk and China's Policy Toward Pakistan: Strategic Reassurance and the 'United Front,"' Journal of Contemporary China 20(71), p. 543-561

Dwyer, Arienne M., "The Xinjiang Conflict: Uyghur Identity, Language, and Political Discourse," East-West Center: Policy Studies 15, 2005, p. 1-70

Dyussembekova, Zhazira, "Silk Road Renewed with New Commercial Transit Route," The Astana Times, January 21, 2016, http://astanatimes.com/2016/01/silk-road-renewedwith-launch-of-new-commercial-transit-route/

Edwards, Pamela J., Williard, Karl J.W. and Schoonover, Jon E., "Fundamental of Watershed Hydrology," Journal of Contemporary Water Research \& Education 154(1), 2015, p. 3-20

Eckholm, Erik, "Out of Guantanamo, Uighurs Bask in Bermuda," The New York Times, June 14, 2009, http://www.nytimes.com/2009/06/15/world/americas/15uighur.html 
Ellison, Herbert J. and Acker, Bruce A., "The New Russia in Asia: 1991-1995," The National Bureau of Asian Research 7(1), 1996, http://www.nbr.org/publications/analysis/pdf/vol7no1.pdf

Erlich, Reese, "As US Sanctions Keep Western Businesses out of Iran, China Seizes the Opportunity," PRI, December 17, 2017, https://www.pri.org/stories/2017-12-28/ussanctions-keep-western-businesses-out-iran-china-seizes-opportunity

Fawcett, Louise, "Exploring Regional Domains: A Comparative History of Regionalism," International Affairs 80(3), 2004, p. 429-446

Fayaz, Sadia, "China's Xinjiang Problem and Pakistan,” The Dialogue VII(3), 2012, p. 235-257

Feng, Qi, Ma, Hua, Jiang, Xuemeim, Wang, Xin, and Cao, Shixiong, "What has Caused Desertification in China?" Scientific Reports 5(15998), 2015, p. 1-8

Fernandez-Stembridge, Leila and Fernandez, Juan Antonio China's State Owned Enterprise Reforms: An Industrial CEO Approach (New York: Routledge, 2007)

Fishman, Brian, "Al-Qaeda and the Rise of China: Jihadi Geopolitics in a PostHegemonic World," The Washington Quarterly 34(3), p. 47-62

Finley, Joanne Smith, "Chinese Oppression in Xinjiang: Middle Eastern Conflicts and Global Islamic Solidarities among the Uyghurs," Journal of Contemporary China 16(53), 2007, p. 627-654

Forbes, Andrew D.W., Warlords and Muslims in Chinese Central Asia: A Political History of Republican Sinkiang 1911-1949 (Cambridge: Cambridge University Press, 1986)

Fravel, M. Taylor, "Regime Insecurity and International Cooperation: Explaining China's Compromises in Territorial Disputes," International Security 30(2), 2005, p. 46-83

Freeman Jr., Chas W., "Energy as China's Achilles Heel?" in China's Energy Strategy: The Impact on Beijing's Maritime Policies, eds. Gabriel B. Collins, Andrew S. Erickson, Lyle J. Goldsteing, and William S. Murray (Annapolis: Naval Institute Press, 2012), p. 13-20

Gabuev, Alexander, "Friends with Benefits?: Russian-Chinese Relations After the Ukrainian Crisis," Carnegie Moscow Center, June 29, 2016, http://carnegie.ru/2016/06/29/friends-with-benefits-russian-chinese-relations-afterukraine-crisis-pub-63953

Gao, Charlotte, "For the First Time, Chinese Communist Party to Hold a World Political Parties Dialogue," The Diplomat, November 29, 2017, 
https://thediplomat.com/2017/11/for-the-first-time-chinese-communist-party-to-hold-aworld-political-parties-dialogue/

Gao, George, "Why is China So...Uncool?” Foreign Policy, March 8, 2017, http://foreignpolicy.com/2017/03/08/why-is-china-so-uncool-soft-power-beijingcensorship-generation-gap/

Gao, Victor Zhikai, “Opinion: Why is Deng Xiaoping's 1992 Southern Inspection Tour Still Relevant Today?” China Global Television Network, January 19, 2018, https://news.cgtn.com/news/3451444e79677a6333566d54/share_p.html

Gernet, Jaques, A History of Chinese Civilization (Cambridge: Cambridge University Press, 1982)

Gill, Bates, "Shanghai Five: An Attempt to Counter U.S. Influence in Asia?" Brookings, May 1, 2001, https://www.brookings.edu/opinions/shanghai-five-an-attempt-to-counteru-s-influence-in-asia/

Ginsburgs, George, From Soviet to Russian International Law: Studies in Continuity and Change (The Hague: Kluwer Law International, 1998)

Glaser, Bonnie S., "Is China Proselytising its Path to Success?" East Asia Forum, January 11, 2018, http://www.eastasiaforum.org/2018/01/11/is-china-proselytising-itspath-to-success/

Goble, Paul, "Ethnic Russians Leaving Central Asia and With Them, Putin's Hopes for Influence," Eurasia Daily Monitor 13(22), 2016, https://jamestown.org/program/ethnicrussians-leaving-central-asia-and-with-them-putins-hopes-for-influence/

Godehardt, Nadine, The Chinese Constitution of Central Asia: Regions and Intertwined actors in International Relations (New York: Palgrave MacMillan, 2014)

Goodman, David S.G., "The Campaign to "Open up the West”: National, ProvincialLevel and Local Perspectives,” The China Quarterly 178, p. 317-334

Gorbachev, Mikhail Sergeevich, "Speech by Mikhail Gorbachev in Vladivostok, July 28, 1986," Novotsi Press Agency Pub. House, July 28, 1986, https://searchworks.stanford.edu/view/1921110

Gordon, Stewart, When Asia was the World: Traveling Merchants, Scholars, Warriors, and Monks Who Created the "Riches of the East" (Philadelphia: Da Capo Books, 2008)

Gorst, Isabel, "Pipeline Brings Asian Gas to China," Financial Times, December 14, 2009, https://www.ft.com/content/38fc5d14-e8d1-11de-a756-00144feab49a

Grewal, Bhajan S. and Ahmed, Abdullah D., "Is China's Western Region Development Strategy on Track? An Assessment," Journal of Contemporary China 20(69), 2011, p. 161-181 
Guang, Pan, "A Chinese Perspective on the Shanghai Cooperation Organization," in The Shanghai Cooperation Organization, eds. Alyson J.K. Bailed, Pal Dunay, Pan Guang, and Mikhail Troitskiy (Stockholm: SIPRI Policy Paper 17, 2007), p. 45-58

Guo, Rongxin, Cross-Border Resource Management, Volume $102^{\text {nd }}$ Edition (Elsevier, 2012)

Haas, Ernst B., "The Study of Regional Integration: Reflections on the Joy and Anguish of Pretheorizing," International Organization 24(4), 1970, p. 606-646

Haas, Ernst B. and Schmitter, Philippe C., "Economic and Differential Patterns of Political Integration: Projections About Unity in Latin America," International Organization 18(4), 1964, p. 705-737

Haas, Ernst B., "Technocracy, Pluralism, and the New Europe," in A New Europe?, ed. Stephen Richards Graubard (Boston: Houghton Mifflin, 1964), p. 62-88

Haas, Ernst B., "International Integration: The European and Universal Process," International Organization 15(3), 1961, p. 366-392

Haas, Ernst B., The Uniting of Europe: Political, Social, and Economic Forces 19501957 (Stanford: Stanford University Press, 1958)

Hadley, Kathryn, "Back when Britain was Banging on Europe's Door," The Guardian, October 13, 2012, https://www.theguardian.com/commentisfree/2012/oct/13/britaineurope-david-cameron-eu

Haider, Irfan, "PM Nawaz Inaugurates Pak-China Friendship Tunnels over Attabad Lake," Dawn, September 14, 2015, https://www.dawn.com/news/1206911

Han, Baocheng, "Importance Attached to Coastal Development," Beijing Review 31(17), April 25-May 1, 1988

Hanks, Reuel R., “'Multi-Vector Politics' and Kazakhstan's Emerging Role as Geostrategic Player in Central Asia," Journal of Balkan and Near Eastern Studies 11(3), 2009, p. 257-267

Harris, Lillian Craig, "Xinjiang, Central Asia and Implication for China's Policy in the Islamic World," The China Quarterly 133, 1993, p. 111-129

Hasanov, Huseyn, "Will China get all Turkmen Gas?” Azernews, April 20, 2015, https://www.azernews.az/analysis/80656.html

Hashmi, Abdul Mateen, "The Eastern, Western, and Central Route of China Pakistan Economic Corridor by Khuram Shahzad," Weekly Batieghar Islamabad, April 29, 2017, http://batieghar.com/index.php/2017/04/29/eastern-western-central-route-china-pakistaneconomic-corridor-khuram-shahzad/ 
$\mathrm{He}, \mathrm{Xu}$, "China-Kyrgyz-Uzbek Railway to Be Finalized in April," China Daily, January 17, 2018, http://www.chinadaily.com.cn/a/201801/17/WS5a5ee7d1a310e4ebf433e4e7.html

Hessbruegge, Jan A., "The Shanghai Cooperation Organization: A Holy Alliance For Central Asia?" al Nakhlah, 2004, http://fletcher.tufts.edu/Al-

Nakhlah/Archives/ /media/Fletcher/Microsites/al\%20Nakhlah/archives/pdfs/hessbruegge $\% 202 . p d f$

Hettne, Bjorn, “Beyond 'New' Regionalism,” New Political Economy 10(4), 2005, p. $543-571$

Hettne, Bjorn, "The New Regionalism Revisited," in Theories of New Regionalism: A Palgrave Reader, eds. Fredrik Soderbaum and Timothy M. Shaw (New York: Palgrave MacMillan, 2003), p. 22-42

Hettne, Bjorn and Soderbaum, Fredrik, "Theorizing the Rise of Regionness," New Political Economy 5(3), 2000, p. 457-472

Hettne, Bjorn and Soderbaum, Fredrik, "Towards Global Social Theory," Journal of International Relations and Development 2(4), 1999, p. 358-368

Hettne, Bjorn and Soderbaum, Fredrik, "The New Regionalism Approach," Politeia 17(3), 1998, p. 6-21

Higgins, Andrew, "China's Ambitious New 'Port': Landlocked Kazakhstan,” The New York Times, January 1, 2018, https://www.nytimes.com/2018/01/01/world/asia/chinakazakhstan-silk-road.html

Higgot, Richard A. and Rossal, Kim Richard, "Australia and the Search for a Community in the 1990s," in Security Communities, eds. Emanuel Adler and Michael Barnett (Cambridge: Cambridge University Press, 1998), p. 265-294

Hoffmann, Stanley, "Obstinate or Obsolete? The Fate of the Nation-State and the Case of Western Europe,” Daedalus 95(3), 1966, p. 862-915

Hoffmann, Stanley, "The European Process at Atlantic Cross Purposes," Journal of Common Market Studies 3(2), 1964, p. 85-101

Hsu, Immanuel C.Y., The Rise of Modern China (New York: Oxford University Press, 1970)

Hu, Bin, "Oil and Gas Cooperation between China and Central Asia in an Environment of Political Resource Competition," Petroleum Science 11, 2014, p. 596-605

Huang, Cary, "China Seeks Role for Yuan in AIIB to Extend Currency's Global Reach," South China Morning Post, April 14, 2015, 
http://www.scmp.com/news/china/economy/article/1766627/china-seeks-role-yuan-aiibextend-currencys-global-reach

Huang, Youji, “Context, not History, Matter for Deng's Famous Phrase," Global Times, June 15, 2011, http://www.globaltimes.cn/content/661734.shtml

Huang, Zheping, "Xi Jinping Says China's Authoritarian System Can Be a Model for the World," Quartz, March 9, 2018, https://qz.com/1225347/xi-jinping-says-chinas-oneparty-authoritarian-system-can-be-a-model-for-the-world/

Hurrell, Andrew, "Explaining the Resurgence of Regionalism in World Politics," Review of International Studies 21(4), 1995, p. 331-358

Hurrell, Andrew "Regionalism in theoretical perspective," in Regionalism in World Politics: Regional Organization and International Order, eds. Louise Fawcett \& Andrew Hurrell (Oxford: Oxford University Press, 1995), p. 37-73

Hussain, Sajid and Khan, Muhammad Ayaz, "CPEC; a Roadmap of Region's

Development," FWU Journal of Social Sciences 11(2), 2017, p. 51-59

Hyer, Eric, "China's Policy Towards Uighur Nationalism," Journal of Muslim Minority Affairs 26(1), 2006, p. 75-86

Hyer, Eric, "The Sino-Russian Boundary Settlement," IBRU Boundary and Security Bulletin, 1996, https://www.dur.ac.uk/resources/ibru/publications/full/bsb4-2_hyer.pdf

Ilie, Elena, "New Eurasia Land Bridge Provides Rail Connection Between China and Europe," Railway Pro, July 15, 2010, https://www.railwaypro.com/wp/new-eurasia-landbridge-provides-rail-connection-between-china-and-europe/

Inglehart, Ronald, "Trends and Nontrends in the Western Alliance: A Review," Journal of Conflict Resolution 12(1), 1968, p. 120-128

Ishaque, Brigadier Waseem, "China-Pakistan Economic Corridor (CPEC): Prospects, Challenges and Way Forward,” NDU Journal 2016, p. 123-146

Jeong, Jihyeon, "Ethnic Minorities in China's Western Development Plan," Journal of International and Area Studies 22(1), 2015, p. 1-18

Jia, Qingguo, “The Shanghai Cooperation Organization: China's Experiment in Multilateral Leadership," in Eager Eyes Fixed on Eurasia: Russia and its Eastern Edge, ed. Iwashita Akihiro (Sapporo: Slavic Research Center, Hokkaido University, 2007), p. $113-123$

Jia, Qingguo, "The Success of the Shanghai Five: Interests, Norms and Pragmatism," Commonwealth Institute, http://www.comw.org/cmp/fulltext/0110jia.htm Jian, Chen, Mao's China and the Cold War (University of North Carolina Press, 2001) 
Johnson, Rob, Oil, Islam, and Conflict: Central Asia Since 1945 (London: Reaktion Books, 2007)

Kaiyr, Azamat and Bupezhanova, Danna, "Nazarbayev Helps Launch Last Section of Kazakhstan-Turkmenistan-Iran Railway," The Astana Times, December 4, 2014, https://astanatimes.com/2014/12/nazarbayev-helps-launch-last-section-kazakhstanturkmenistan-iran-railway/

Kan, Shirley, "U.S.-China Counter-Terrorism Cooperation: Issues for U.S. Policy," CRS Report for Congress, December 7, 2004, p. 1-36, https://fas.org/irp/crs/RS21995.pdf

Kellner, Thierry, "China: The Uighur Situation from Independence for the Central Asian Republics to the Post 11 September Era," refworld, 2002, p. 8, http://www.refworld.org/docid/465e8a292.html

Khan, Zahid and Guo, Changgang, "China's Energy Driven Initiatives with Iran: Implications for the United States," Journal of Middle Eastern and Islamic Studies 11(4), 2017, p. 15-31

Khrushchev, Sergey, Memoirs of Nikita Khrushchev Volume 3, (University Park: Pennsylvania State University Press, 2007)

Khrushchev, Nikita Sergeyevich, Pravda, September 20, 1964, translated in The Current Digest of the Soviet Press 16(38), October 14, 1964, p. 3-7

Khrushchev, Nikita Sergeyevich, "Khrushchev's Secret Speech, 'On the Cult of Personality and its Consequences.' Delivered at the Twentieth Party Congress of the Communist Party of the Soviet Union," The Wilson Center Digital Archive, February 25, 1956, http://digitalarchive.wilsoncenter.org/document/115995

Kim, Samuel S., "Mainland China in a Changing Asia-Pacific Regional Order," in Contemporary China in the Post-Cold War Era, eds. Bih-jaw Lin and James T. Myers (Columbia: University of South Carolina Press, 1996), p. 263-305

Kimmage, Daniel, "Central Asia: Turkmenistan-China Pipeline Project Has Far-Reaching Implications," Radio Free Europe Radio Liberty, April 10, 2006, https://www.rferl.org/a/1067535.html

Kirshner, Jonathan, American Power After the Financial Crisis (Ithaca: Cornell University Press, 2014)

Kissane, Carolyn, "Education in Central Asia: Traditional Challenges and Impacts," in The Politics of Transition in Central Asia and the Caucasus: Enduring Legacies and Emerging Challenges, eds. Amanda E. Wooden and Christopher H. Stefes (New York: Routledge, 2009), p. 226-248 
Kramer, Mark, "The Soviet Ministry Appraisal of Sino-Soviet Relations on the Eve of the Split," in The Cold War in Asia, Cold War International History Project Bulletin 6-7, 1995/1996, p. 170-185

Kreamer, Andrew E., "New Gas Pipeline from Central Asia Feeds China," The New York Times, December 14, 2009, http://www.nytimes.com/2009/12/15/world/asia/15pipeline.html

Kuisong, Yang, "The Sino-Soviet Border Clash of 1969: From Zhenbao Island to SinoAmerican Rapprochement," Cold War History 1(1), 2000, p. 21-52

Kuo, Lily, "Beijing is Cultivating the Next Generation of African Elites by Training them in China," Quartz, December 14, 2017, https://qz.com/1119447/china-is-training-africasnext-generation-of-leaders

Laffan, Brigid and Mazey, Sonia, "European Integration: the European Union - Reaching an Equilibrium?" in European Union: Power and Policy-Making $3^{\text {rd }}$ edition, ed. Jeremy Richardson (New York: Routledge, 2006), p. 31-54

Lai, Benjamin, The Dragon's Teeth: The Chinese People's Liberation Army - Its History, Traditions, and Air, Sea, and Land Capabilities in the $21^{\text {st }}$ Century (Havertown:

Casemate Publishers, 2016)

Lai, Hongyi Harry, “China’s Western Development Program: Its Rationale, Implementation, and Prospects," Modern China 28(4), 2002, p. 432-466

Lam, Willy Wo-Lap, "Provincial Leaders Link Aid, Law, Order," Hong Kong, September 9, 1995, FBIS-CHI-95-175, September 11, 1995

Landau, Jacob M. and Kellner-Heinkele, Barbara, Language Politics in Contemporary Central Asia: National and Ethnic Identity and the Soviet Legacy (London: I.B. Tauris, 2012)

Lanteigne, Mark, "China's Maritime Security and the "Malacca Dilemma,"” Asian Security 4(2), 2008, p. 143-161

Laruelle, Marlene and Peyrouse, Sebastien, Globalizing Central Asia: Geopolitics and the Challenges of Economic Development (New York: M.E. Sharpe, 2013)

Leigh, David, "Guantanamo Files: China Among Regimes Invited to Interrogate Captives," The Guardian, April 24, 2011, https://www.theguardian.com/world/2011/apr/25/guantanamo-files-china-interrogatedprisoners

Lewis, Martin W. and Wigen, Karen E., The Myth of Continents: A Critique of Meta Geography (Berkeley: University of California Press, 1997) 
Li, Keqiang, "Full Text: Report on the Work of the Government (2015)," The State Council of the People's Republic of China, March 16, 2015, http://english.gov.cn/archive/publications/2015/03/05/content_281475066179954.htm

Li, Keqiang, "Full Text: Report on the Work of the Government (2014)," The National People's Congress of the People's Republic of China, March 18, 2014, http://www.npc.gov.cn/englishnpc/Speeches/2014-03/18/content_1856703.htm

Li, Peng, "Report on the outline of the Ninth Five-Year Plan (1996-2000) for National Economic and Social Development and the Long-range Objectives to the Year 2010 (Excerpts)," China.org, 1996, http://www.china.org.cn/95e/95-english1/2.htm

Lin, Hsiao-tin, "Nationalists, Muslim Warlords, and the "Great Northwestern Development" in Pre-Communist China," China and Eurasia Quarterly Forum 5(1), 2007, p. 115-135

Lin, Lili and Shi, Zihan, "Xinjiang's First Oil Well,” China Daily, July 10, 2015, https://www.chinadaily.com.cn/m/xinjiang/karamay/2015-07/10/content_21894342.htm

Lin, Wanxia, "Silk Road Scholarships to Expand China's Links to Eurasia," Asia Times, November 28, 2016, http://www.atimes.com/article/silk-road-scholarships-expandchinas-links-eurasia/

Lindberg, Leon N. and Scheingold, Stuart A., Europe's Would-be Polity: Patterns of Change in the European Community (Englewood Cliffs: Prentice Hall, 1970)

Lindberg, Leon N., The Political Dynamics of European Economic Integration (Stanford: Stanford University Press, 1963)

Linn, Johannes, "Central Asia Regional Integration and Cooperation: Reality or Mirage?," in Eurasian Integration Yearbook 2012, eds. Evgeny Vinokurov (Eurasian Development Bank), p. 96-117

Liu, Xin and Meng, Xianglin, "Xi Offers Model for Governance," Global Times, December 1, 2017, http://www.globaltimes.cn/content/1078275.shtml

Liu, Xinru, The Silk Road: A Brief History with Documents (Boston: Bedford/St. Martin's, 2012)

Liu, Xinru, The Silk Road in World History (Oxford: Oxford University Press, 2010)

Liu, Yazhou, "On Advance Toward the West," 2010, http://www3.nd.edu/ pmoody/Text\%20Pages\%20-\%20Peter\%20Moody\%20Webpage/Li u\%20Yazhou.htm

Low, Alfred D., The Sino-Soviet Dispute: An Analysis of the Polemics (London: Associated University Presses, 1976) 
Lu, Hui, "Commentary: Milestone Congress Points to a New Era for China, the world," Xinhuanet, October 24, 2017, http://www.xinhuanet.com/english/201710/24/c_136702090.htm

Luce, Thomas, "Kazakhstan's Reform and Development Play," Silk Road Reporters, November 15, 2014, http://www.silkroadreporters.com/2014/11/15/kazakhstans-reformdevelopment-play/

Luthi, Lorenz M., The Sino-Soviet Split: The Cold War in the Communist World (New Jersey: Princeton University Press, 2008)

Ma, Dazheng, "The Tarim Basin," in History of Civilizations of Central Asia: Volume V Development in Contrast: from the Sixteenth to the Mid-Nineteenth Century, eds.

Chahryar Adle, Irfan Habib, and Karl M. Baikapov (Paris: UNESCO Publishing 2003)

Macfie, Nick, "China's Li Offers to Help End Pakistan Energy crisis," Reuters, May 22, 2013 , https://web.archive.org/web/20131230003027/http://www.reuters.com/article/2013/05/22 /us-pakistan-china-idUSBRE94L06G20130522

MacMillan, Ian, "Chinese Premier Begins Goodwill Tour of Central Asia," Los Angeles Times, 1994, http://articles.latimes.com/1994-04-20/news/mn-48237_1_central-asia

Maitra, Ramtanu, "Kyrgyzstan and Tajikistan: The Crucial Challenge in Central Asian Development," Executive Intelligence Review, February 3, 2017, p. 26, https://www.larouchepub.com/eiw/public/2017/eirv44n05-20170203/24-31_4405.pdf

Maitra, Ramtanu, “The Multiple Dimensions of China's 'One Belt One Road' in Uzbekistan," The Schiller Institute, February 2017,

http://www.schillerinstitute.org/economy/phys_econ/2016/1227-oboruzbek/ou.html\#footnote-138676-4

Mammadov, Qaya, "Turkmenistan Positions Itself as Eurasian Natural Gas Power," Oil \& Gas Journal, December 7, 2015, https://www.ogj.com/articles/print/volume-113/issue12/transportation/turkmenistan-positions-itself-as-eurasian-natural-gas-power.html Mann, Michael, "Ruling Class Strategies and Citizenship," in The State: Critical Concepts Volume III, ed. John A. Hall (New York: Routledge, 1994), p. 40-56

Mao Tse-Tung, Selected Works of Mao Tse-Tung Volume II (Peking: Foreign Language Press, 1965)

Mariani, Bernardo, "China's Role and Interests in Central Asia," Saferworld, 2013, https://www.files.ethz.ch/isn/172938/chinas-role-and-interests-in-central-asia.pdf

Mark, Chi-Kwan, The Everyday Cold War: Britain and China, 1950-1972 (London: Bloomsbury Publishing PLC, 2017) 
Martina, Michael and Blanchard, Ben, "Uighur IS Fighters Vow Blood will 'Flow in Rovers' in China," Reuters, March 1, https://www.reuters.com/article/us-mideast-crisisiraq-china/uighur-is-fighters-vow-blood-will-flow-in-rivers-in-china-idUSKBN16848H

Mathur, Dinesh, "Chinese Perceptions of Various Territorial Disputes," CLAWS Journal, 2008, p. 134-150

Maxwell, Neville, "How the Sino-Russian Boundary Conflict was Finally Settled," Critical Asian Studies 39(2), 2007), p. 229-253

McCord, Steven, "Belt Road Initiative Opens Up New Investment Opportunities," The Investor, June 8, 2017, https://www.theinvestor.jl1/news/asia-pacific/bri/belt-roadinitiative-opens-new-investment-opportunities/

McKinley, Ryan, "Market Capture: China's Energy Relationship with Turkmenistan," Enerpo Journal, October 31, 2014, https://enerpojournal.com/2014/10/31/marketcapture-chinas-energy-relationship-with-turkmenistan/

Michel, Casey, "China's Canceled Pipeline Puts Central Asia Back at Integration Drawing Board," World Politics Review, April 19, 2017, https://www.worldpoliticsreview.com/articles/21868/china-s-canceled-pipeline-putscentral-asia-back-at-the-integration-drawing-board

Miller, Alice L., “An Uneasy Alliance,” Hoover Institution No. 3, July 30, 2002, https://www.hoover.org/research/uneasy-alliance

Millward, James A. and Tursun, Nabijan, "Political History and Strategies of Control, 1884-1978, in Xinjiang as China's Muslim Borderland, ed. S. Fredrick Starr (Armonk: M.E. Sharpe, 2004), p. 63-100

Milward, Alan, The European Rescue of the Nation-State (New York: Routledge, 1992)

Mitchell, Garret, "China in Central Asia: The Beginning of the End for Russia?" SLOVO 26(1), 2014, p. 18-31

Mitrany, David, A Working Peace System (Chicago: Quadrangle Books, 1966)

Mitrany, David, "The Prospect of Integration: Federal or Functional," Journal of Common Market Studies 4(1), 1965, p. 119-149

Mitrany, David, "The Functional Approach to World Organization," International Affairs 24(3), 1948, p. 350-363

Mitrany, David, The Progress of International Government (London: G. Allen \& Unwin, 1933) 
Moneyhon, Matthew D., “China’s Great Western Development Project in Xinjiang, Economic Palliative, or Political Trojan Horse?" Denver Journal of International Law \& Policy 31(3), 2003, p. 491-519

Moravcsik, Andrew, The Choice for Europe: Social Purpose \& State Power from Messina to Maastrich (Ithaca: Cornell University Press, 1998)

Moravcsik, Andrew, "Preferences and Power in the European Community: A Liberal Intergovernmentalist Approach," Journal of Common Market Studies 31(4), 1993, p. 473524

Moravcsik, Andrew, "Negotiating the Single European Act: National Interests and Conventional Statecraft in the European Community," International Organization 45(1), 1991, p. 19-56

Moseley, George, A Sino-Soviet Cultural Frontier: The Ili Kazakh Autonomous Chou (Cambridge: Harvard University Press, 1966)

Mount, Ian, "Spain to China by Rail: A $21^{\text {st }}$ Century Silk Road Riddled with Obstacles," Fortune, December 24, 2014, http://fortune.com/2014/12/24/spain-china-rail-trade/

Nan Zhu, "PRC: Xinjiang Chairman Cautions Against Ethnic Splittism," Urumqi Xinjiang Ribao, April 21, 1991, FBIS-CHI-96-097, May 17, 1996

Neumann, Iver B., "A Region-Building Approach," in Theories of New Regionalism: A Palgrave Reader, eds. Fredrik Soderbaum and Timothy M. Shaw (New York: Palgrave MacMillan, 2003), p. 160-178

Neumann, Iver B., “A Region-Building Approach to Northern Europe,” Review of International Studies 20(1), 1994, p. 53-74

Ng, Teddy, "Xi Jinping Secures Greater Security and Energy Ties with Turkmenistan," South china Morning Post, September 3, 2013, http://www.scmp.com/news/china/article/1302636/xi-arrives-turkmenistan-first-legcentral-asia-tour

Nichol, Jim, "Central Asia's Security: Issues and Implications for U.S. Interests," Congressional Research Service, March 11, 2010, p. 1-67, https://fas.org/sgp/crs/row/RL30294.pdf

Nienmann, Arne and Schmitter, Philippe C., "Neofuntionalism," in European Integration Theory $2^{\text {nd }}$ Edition, eds. Antje Wiener and Thomas Diez (Oxford, Oxford University Press, 2009), p. 45-66

Niemann, Arne, Explaining Decisions in the European Union (Cambridge, Cambridge University Press, 2006) 
Nye, Josef S., Peace in Parts: Integration and Conflict in Regional Organization (Boston: Little, Brown \& Company, 1971)

Olcott, Maria Brill, Central Asia's New States: Independence, Foreign Policy, and Regional Security (Washington DC: United States Institute of Peace Press)

O'Neil, Daniel C., "Risky Business: The Political Economy of Chinese Investment in Kazakhstan," Journal of Eurasian Studies 5, 2014, p. 145-156

Ong, Russell "China's Security Interests in Central Asia," Central Asian Survey 24(4), 2005, p. 425-439

Orazgaliyeva, Malika, "Kazakhstan, China Ink \$14 Billion in Cooperation Deals," The Astana Times, December 17, 2014, https://astanatimes.com/2014/12/kazakhstan-chinaink-14-billion-cooperation-deals/

Orozobekova, Cholpon, "China Relocating Heavy Enterprises to Kyrgyzstan," Eurasia Daily Monitor, The Jamestown Foundation, June 24, 2016, https://jamestown.org/program/china-relocating-heavy-enterprises-to-kyrgyzstan/

Parks, Michael, "Demilitarized Border Urged by Gorbachev," Los Angeles Times, May 17, 1989, http://articles.latimes.com/1989-05-17/news/mn-121_1_sino-soviet-gorbachevsoviet-officials/2

Pan, Junwu, Toward a Framework for Peaceful Settlement of China's Territorial and Boundary Disputes (Leiden: Martinus Nijhoff Publishers, 2009)

Panfilova, Victoria, "Russian Exodus Continues from Central Asia," Russia \& India Report, August 25, 2014, http://in.rbth.com/world/2014/08/25/russian_exodus_continues_from_central_asia_37791

Pannier, Bruce, "Turkmen Exports to Iran a Boom for Both Countries," Radio Free Europe Radio Liberty, January 6, 2010, https://www.rferl.org/a/Turkmen_Gas_Exports_To_Iran_A_Boon_For_Both_Countries/1 921933/p1.html?contenttype=1\#relatedInfoContainer

Pannier, Bruce, "Pipeline Explosion Raises Tension Between Turkmenistan, Russia," Radio Free Europe Radio Free Liberty, April 14, 2009, https://www.rferl.org/a/Pipeline_Explosion_Stokes_Tensions_Between_Turkmenistan_R ussia/1608633.html

Pantucci, Rafaello, "Central Asia: The View from China," European Union Institute for Security Studies, 2015, https://www.iss.europa.eu/sites/default/files/EUISSFiles/Alert_3_Central_Asia_China.pd $\mathrm{f}$ 
Perdue, Peter C., China Marches West: The Qing Conquest of Central Eurasia (Massachusetts: The Belknap Press of Harvard University Press, 2005)

Petersen, Alexandros and Starr, Frederik S., Eurasia's Shifting Geopolitical Tectonic Plates: Global Perspective, Local Theaters (Lanham: Lexington Books, 2017)

Petersen, Alexandros, "Chinese Refinery in Kyrgyzstan to Reduce Russian Leverage," China in Central Asia, April 13, 2013, http://chinaincentralasia.com/2013/04/03/chineserefinery-in-kyrgyzstan-to-reduce-russian-leverage/

Peyrouse, Sebastien, "The Russian Minority in Central Asia: Migration, Politics, and Language," Kennan Institute Occasional Paper \# 297, 2008, https://www.wilsoncenter.org/sites/default/files/OP297.pdf

Peyrouse, Sebastien, "Discussing China: Sinophilia and Sinophobia in Central Asia," Journal of Eurasian Studies 7, 2005, p. 14-23

Phillips, Tom, "China: Xi Jinping wants 'Great Wall of Steel' in Violence-hit Xinjiang," The Guardian, March 10, 2017, https://www.theguardian.com/world/2017/mar/11/chinaxi-jinping-wants-great-wall-of-steel-in-violence-hit-xinjiang

Pikalov, Alexander, "Uzbekistan Between the Great Powers: A Balancing Act or a MultiVectoral Approach," Central Asian Survey 33(3), 2014, p. 297-311

Pinder, John, "Positive Integration and Negative Integration: Some Problems of Economic Union in the EEC," The World Today 24(3), 1968, p. 88-110

Pomfret, John, "China: Go West, Young Han; Beijing Urging Dominant Ethnic Group to Resettle, Develop Restive Regions," The Washington Post, September 15, 2000, https://search-proquestcom.ezproxy.fiu.edu/news/docview/409046210/fulltext/560088F9060E4F8APQ/1?accou ntid=10901

Postel-Vinay, Karoline, "The Historicity of the International Region: Revisiting the "Europe and the Rest" Divide," Geopolitics 12(4), 2007, p. 555-569

Rajabova, Sara, "China to Construct Oil Refinery in Tajikistan," Azernews, March 10, 2015, https://www.azernews.az/region/78842.html

Rastogi, Cordula and Arvis, Jean-Francois, "The Eurasian Connection: Supply-Chain Efficiency Along the Modern Silk Road through Central Asia," The World Bank, 2014, p. $1-111$, http://documents.worldbank.org/curated/en/730031468030581540/pdf/888910PUB0Box 300EPI199120June122014.pdf 
Qi, Ren, "China Daily Reporter Visits Confucius Institutes on the Belt and Road," Hanban News, December 26, 2016, http://english.hanban.org/article/201612/21/content_668899.htm

Rahimov, Mirzohid, "The Pap-Angren Railway and its Geoeconomic Implications for Central Asia," The Central Asia-Caucasus Analyst, April 19, 2016, https://www.cacianalyst.org/publications/analytical-articles/item/13354-the-pap-angrenrailway-and-its-geoeconomic-implications-for-central-asia.html

Rapoza, Kenneth, "Eurasia's Latest Economic Reboot Can Be Found in Uzbekistan," Forbes, September 14, 2017, https://www.forbes.com/sites/kenrapoza/2017/09/14/eurasias-new-perestroikauzbekistan-silk-road-china/\#8a6cdf66f25c

Recknagel, Charles, "China Emerges as the Big Winner in 2009," Radio Free Europe/Radio Liberty, December 35, 2009, http://www.rferl.org/a/China_Emerges_As_The_Big_Winner_In_2009/1913628.html Reed, J. Todd and Raschke, Diana, The ETIM: China's Islamic Militants and the Global Terrorist Threat (Santa Barbara: Praeger, 2010)

Robinson, Thomas W., "The Sino-Soviet Border Dispute: Background, Development, and the March 1969 Clashes," American Political Science Review 66(4), 1972, p. 11751202

Rodriguez, Pablo A., "Violent Resistance in Xinjiang (China): Tracking Militancy, Ethnic Riots and 'Knife-Wielding' Terrorist (1972-2012)," Historia Actual Online 30, 2013, http://www.historia-actual.org/Publicaciones/index.php/haol/article/view/820/672

Rosamond, Ben, Theories of European Integration (New York: Palgrave MacMillan, 2000)

Ruwitch, John, Martina, Michael, and Shepherd, Christian, "China's Xi Calls for 'Great Wall of Iron' to Safeguard Restive Xinjiang," Reuters, March 9, https://www.reuters.com/article/us-china-security-xinjiang/chinas-xi-calls-for-great-wallof-iron-to-safeguard-restive-xinjiang-idUSKBN16H04J

Santoro, David, "European and P5 Responses to Iran's Nuclear Program," in International Cooperation on WMD Nonproliferation, ed. Jeffrey Knopf (Athens: University of Georgia Press, 2016)

Schmitter, Philippe C., "A Revised Theory of Regional Integration," International Organization 24(4), 1970, p. 836-868

Schmitter, Philippe C., "Three Neo-Functional Hypotheses about International Integration," International Organization 23(1), 1969, p. 161-166 
Michael Schwartz, "The Development of the Sino-Iranian Limited Partnership: China's \$600-Billion Proposition," Middle East Economy 6(9), 2016, p. 6, https://dayan.org/content/development-sino-iranian-limited-partnershipchina\%E2\%80\%99s-600-billion-proposition

Scobell, Andrew, "Chinese Foreign Policy and the War on Terror," The Jamestown Foundation Terrorism Monitor 2(2), May 5, 2005, https://jamestown.org/program/chinese-foreign-policy-and-the-war-on-terror/

ShahBazov, Fuad, "China's Economic and Military Expansion in Tajikistan," The Diplomat, November 23, 2016, https://thediplomat.com/2016/11/chinas-economic-andmilitary-expansion-in-tajikistan/

Suyunbek Shamshiev, "Alternative Road North-South in Kyrgyzstan Built on New Technology," 24, May 19, 2017, https://24.kg/english/52135_Alternative_road_North_South_in_Kyrgyzstan_built_on_n ew_technology/

Shepard, Wade, "Beijing to the World: Don't Call the Belt and Road Initiative OBOR," Forbes, August 1, 2017, https://www.forbes.com/sites/wadeshepard/2017/08/01/beijingto-the-world-please-stop-saying-obor/\#3db282bc17d4

Shepard, Wade, "Khorgos: The New Silk Road's Central Asian Station Comes to Life, Forbes, February 20, 2017, https://www.forbes.com/sites/wadeshepard/2017/02/20/khorgos-the-new-silk-roadscentral-station-comes-to-life/\#54f6e3c4c22e

Shepard, Wade, "Why the China-Europe 'Silk Road' Rail Network is Growing Fast," Forbes, January 28, 2016, http://www.forbes.com/sites/wadeshepard/2016/01/28/whychina-europe-silk-road-rail-transport-is-growing-fast/\#7ede739b7f24

Shichor, Yitzhak, "The Great Wall of Steel: Military and Strategy in Xinjiang," in Xinjiang: China's Muslim Borderland, ed. S. Fredrick Starr (Armonk: M.E. Sharpe, 2004), p. 120-162

Shih, Victor, "Development, the Second Time Around: The Political Logic of Developing Western China," Journal of East Asian Studies 4(3), 2004, p. 427-451

Shuja, Sharif, "China's Energy needs and Central Asia," National Observer 67, Summer 2006, http://www.nationalobserver.net/2006_sharif_summer.htm

Soucek, Svat, A History of Inner Asia (Cambridge: Cambridge University Press, 2000)

Spinelli, Altiero, The European Adventure: Tasks for the Enlarged Community, translated by G. Lovett (Knight (Charles) \& Co. Ltd., 1972) 
Spinelli, Altiero, "The Ventone Manifesto," translated by E. Urgesi, 1944, http://www.altierospinelli.org/manifesto/en/pdf/manifesto1944en.pdf

Sodiqov, Alexander, "Tajikistan Cedes Disputed Land to China," Eurasia Daily Monitor 8(16), January 24, 2011, https://jamestown.org/program/tajikistan-cedes-disputed-landto-china/

Stegen, Karen Smith, "Outcomes and Strategies in the 'New Great Game': China and the Caspian States Emerge as Winners," Journal of Eurasian Studies 6(2), 2015, p. 91-106

Stoban, P., “China's Central Asia Dilemma," Strategic Analysis 22(3), 1998, p. 399-408

Stoops, Stanley W. "The Demography of Xinjiang," in Xinjiang: China's Muslim

Borderland, ed. S. Fredrick Starr (Armonk: M.E. Sharpe, 2004), p. 241-263

Storey, Ian, “China's “Malacca Dilemma,"” China Brief 6(8), 2006, https://jamestown.org/program/chinas-malacca-dilemma/

$\mathrm{Su}$, Yuting, "World Political Parties Dialogue Concludes with 'Beijing Initiative,"” China Global Television Network, December 3, 2017, https://america.cgtn.com/2017/12/03/world-political-parties-dialogue-beijing-initiative

Sun, Yun "Westward Ho!: As America Pivots East, China Marches in the Other Direction," Foreign Policy, February 7, 2013, http://foreignpolicy.com/2013/02/07/westward-ho-2/

Sun, Zhuangzi, "The Relationship between China and Central Asia," in Eager Eyes Fixed on Eurasia: Russia and its Eastern Edge, ed. Iwashita Akihiro (Sapporo: Slavic Research Center, Hokkaido University, 2007), p. 41-63

Sussex, Matthew, "From Retrenchment to Revanchism....and Back Again? Russian Grand Strategy in the Eurasian "Heartland," in Russia, Eurasia and the New Geopolitics of Energy: Confrontation and Consolidation, eds. Matthew Sussex and Roger E. Kanet (New York: Palgrave MacMillan, 2015), p. 19-41

Taldybayeva, Dinara, "Prospects for China - Kyrgyzstan Economic Relations in the Framework of the Silk Road Economic Belt Project," Hong Kong Trade Development Council, March 28, 2017, http://china-trade-research.hktdc.com/businessnews/article/The-Belt-and-Road-Initiative/Prospects-for-China-Kyrgyzstan-EconomicRelations-in-the-Framework-of-the-Silk-Road-Economic-BeltProject/obor/en/1/1X000000/1X0A9JIX.htm

Tang, Donald, "China's Investment in the Central Asian Republics," The Foreign Military Studies Office, 2015, p. 3-26;

http://fmso.leavenworth.army.mil/documents/China/DonaldTang_China_CentralAsianRe publics.pdf 
Taubman, William, Khrushchev: The Man and His Era (London: Simon \& Schuster, 2005)

Taylor, Adam, "China treats its foreign aid like a state secret. New research aims to reveal it," The Washington Post, October 11, 2017, https://www.washingtonpost.com/news/worldviews/wp/2017/10/11/china-treats-itsforeign-aid-like-a-state-secret-new-research-aims-to-reveal-it/?utm_term=.c812a4b34228

Thompson, William R., "The Regional Sub-system: A Conceptual Explication and a Propositional Inventory," International Studies Quarterly 17(1), 1973, p. 89-117

Tian, Qunjian, “China Develops its West: Motivation, Strategy and Prospect," Journal of Contemporary China 13(41), 2004, p. 611-636

Tilly, Charles, The Formation of National States in Western Europe (Princeton: Princeton University Press, 1975)

Tokbaeva, Dina, "Shanghai Cooperation Organization: Paper Tiger or Sleeping Dragon?" Institute for War \& Peace Reporting, September 26, 2016, https://iwpr.net/globalvoices/shanghai-cooperation-organisation-paper-tiger

Toops, Stanley, "Spatial Results of the 2010 Census in Xinjiang," China Policy Institute, March 7, 2016, https://cpianalysis.org/2016/03/07/spatial-results-of-the-2010-census-inxinjiang/

Tranholm-Mikkelsen, Jeppe, "Neo-Functionalism: Obstinate or Obsolete? A Reappraisal in Light of the New Dynamism of the EC," Millennium: Journal of International Studies 20(1), 1991, p. 1-22

Tukmadiyeva, Malika, "Xinjiang in China's Foreign Policy Toward Central Asia," The Quarterly Journal, Summer 2013, p. 87-107

Tyler, Christian, Wild West China: The Taming of Xinjiang (New Brunswick: Rutgers University Press, 2004)

Tzou, Byron N., China and International Law: The Boundary Disputes (New York: Praeger, 1990)

Van der Kley, Dirk, "Can Central Asia's Poorest Countries Pay Back Their Debts to China?” The Diplomat, December 1, 2017, https://thediplomat.com/2017/12/can-centralasias-poorest-states-pay-back-their-debts-to-china/

Van der Kley, Dirk “Chinese Companies Increasingly Employ Central Asians," China in Central Asia, December 27, 2016, http://chinaincentralasia.com/2016/12/27/chinesecompanies-increasingly-employ-central-asians/ 
Van der Kley, Dirk "China Shifts Polluting Cement to Tajikistan," China Dialogue, August 8, 2016, https://www.chinadialogue.net/article/show/single/en/9174-China-shiftspolluting-cement-to-Tajikistan

Van wie Davis, Elizabeth, "Uyghur Muslim Ethnic Separatism in Xinjiang, China," AsiaPacific Center for Security Studies, 2008, http://apcss.org/college/publications/uyghurmuslim-ethnic-separatism-in-xinjiang-china/

Waever, Ole "Securitization and Desecuritization," in On Security, ed. Ronnie Lipschutz (New York: Columbia University Press, 1995), p. 46-86

Walsh, J. Richard, "China and the New Geopolitics of Central Asia," Asian Survey 33(3), 1993, p. 272-284

Wang, Jisi, "March West: Rebalancing China's Geopolitical Strategy," Global Times, 2012, http://opinion.huanqiu.com/opinion_world/2012-10/3193760.html

Wang, Lei, "26 Years on: Deng Xiaoping Reaffirms China's Commitment to Reform," China Global Television Network, January 18, 2018, https://news.cgtn.com/news/78497a4d79677a6333566d54/share_p.html

Wang, Xing, "Institute Brings Knowledge of Chinese Culture to Kazakhs," China Daily USA, June 15, 2011, http://usa.chinadaily.com.cn/epaper/201106/15/content_12701171.htm

Wang, Zhuwei, "Securing Energy Flows from Central Asia to China and the Relevance of the Energy Charter Treaty to China," Energy Charter Secretariat, 2015, p. 7-66, https://energycharter.org/fileadmin/DocumentsMedia/Thematic/China_and_the_ECT_20 15_en.pdf

Warikoo, K., "Xinjiang under the Qings," in Xinjiang - China's Northwest Frontier, ed. K. Warikoo (NY: Routledge 2016)

Warktotsch, Alexander, "The Caspian Region: The Struggle for Resources," in The Neighbors of the European Union's Neighbors: Diplomatic and Geopolitical dimensions Beyond, eds. Sieglinde Gstohl and Erwan Lannon (Burlington: Ashgate Publishing Company 2014) p. 181-199

Weimer, Calla, "The Economy of Xinjiang," in Xinjiang: China's Muslim Borderland, ed. S. Fredrick Starr (Armonk: M.E. Sharpe, 2004), p. 163-189

Wendt, Alexander, Social Theory of International Relations (Cambridge: Cambridge University Press, 1999)

Wendt, Alexander, "Anarchy is What States Make of It: The Social Construction of Power Politics," International Organization 46(2), 1992, p. 391-425 
Whiting, Allen S., Sinkiang Pivot or Pawn? (East Lansing: Michigan State University Press, 1958)

Williams, Michael C., "Words, Images, Enemies: Securitization and International Politics," International Studies Quarterly 47, 2003, p. 511-531

Wong, Cal, “One Belt, One Road, One Language?” The Diplomat, May 12, 2017, http://thediplomat.com/2017/05/one-belt-one-road-one-language/

Wu, Gang and Yan, Shuang, "Xi Jinping Pledges 'Great Renewal of Chinese Nation," Global Times, November 30, 2012, http://www.globaltimes.cn/content/747443.shtml

Wu, Jiao and Zhang, Yunbi, "Xi Proposes a "New Silk Road' with Central Asia," China Daily, September 8, 2013, http://usa.chinadaily.com.cn/china/201309/08/content_16952304.htm

Wu, Yuqing, "Ten Years After "Go West,"” Journal of the Washington Institute of China Studies 4(2), 2009, p. 1-8

Xi, Jinping, "Full Text of Xi Jinping's Report at $19^{\text {th }}$ CPC National Congress," China Daily, November 4, 2017, http://www.chinadaily.com.cn/china/19thcpcnationalcongress/201711/04/content_34115212.htm

Xi, Jinping, "Work Together for a Bright Future of China-Iran Relations: President Xi," The Iran Project, January 22, 2016, https://theiranproject.com/blog/2016/01/22/worktogether-for-a-bright-future-of-china-iran-relations-president-xi-2/

Xin, Zhou, "China, Iran Opens 'New Chapter' in Bilateral Ties as President Xi Jinping Visits Tehran as Peacemaker, Power Broker and Major Buyer of Oil," South China Morning Post, January 24, 2016, http://www.scmp.com/news/china/diplomacydefence/article/1904328/china-iran-opens-new-chapter-bilateral-ties-president

Xu, Jinzhou, "Analysis of 1969's "Order Number One," in Selected Essays on the History of Contemporary China, ed. Xingxing Zhang (Leiden: Brill, 2015), p. 168-193

Yang, Dali L., Beyond Beijing: Liberalization and the Regions in China (London: Routledge, 1997)

Yang Guihua, "Treasure Island Self-Defense Counterattack in 1969," People, July 4, 2002, http://www.people.com.cn/GB/junshi/192/8559/8564/20020704/768476.html

Yang, Kai, "The More Powerful the CCP is, the Better the World Is," Renmin, October 1, 2017, http://paper.people.com.cn/rmrbhwb/html/2017-10/18/content_1811226.htm

Yang, Sheng and Wang, Cong, "Trump Tweet Draws China, Pakistan Closer," Global Times, January 4, 2018, http://www.globaltimes.cn/content/1083361.shtml 
Yao, Nian, "Xinjiang's Horgos Land Port Helps Boost Local Economy," China Global Television Network, June 14, 2017, https://news.cgtn.com/news/3d676a4d3549444e/share_p.html

Yeh, Emily T. and Wharton, Elizabeth, "Going West and Going Out, Migrants, and Models of Chinese Development," Eurasian Geography and Economics 57(3), 2016, p. 286-315

Yuan, Jong-Dong, "China's Role in Establishing and Building the Shanghai Cooperation Organization (SCO)," Journal of Contemporary China 19(67), 2010, p. 855-869

Zhang, Junhua, "What's Driving China's One Belt, One Road Initiative?" East Asia Forum, September 2, 2016, http://www.eastasiaforum.org/2016/09/02/whats-drivingchinas-one-belt-one-road-initiative/

Zhang, Xiaoming, Deng Xiaoping's Long War: The Military Conflict between China and Vietnam, 1979-1991 (Chapel Hill: The University of North Carolina, 2015)

Zhao, Huasheng, "Central Asia in China's Diplomacy," in Central Asia: Views from Washington, Moscow, and Beijing, eds. Eugene Rumer, Dmitri Trenin, and Huasheng Zhao (Armonk: M.E. Sharpe, Inc. 2007), p. 137-213

Zhao, Xiaodong, "The Shanghai Cooperation Organization and Counter-Terrorism Cooperation," Institute for Security \& Development, 2012, http://isdp.eu/content/uploads/publications/2012_zhao_the-shanghai-cooperationorganisation.pdf

Zhao, Ziyang, “Zhao on Coastal Areas' Development Strategy," Beijing Review 31(6), February 8-14, 1988, p. 14-19

Zhao, Ziyang, "Advance Along the Road of Socialism with Chinese Characteristics," Beijing Review 30(45), November 9-15, 1987, p. I-XXVII

Zhu, Rongji, "Report on the Outline of the Tenth Five-Year Plan for National Economic and Social Development (2001)," The Central People's Government of the People's Republic of China, 2001, http://english1.english.gov.cn/official/200507/29/content_18334.htm

Ziegler, Charles E., "Sovereignty, Security and Intervention in Central Asia," in Russia, Eurasia and the New Geopolitics of Energy: Confrontation and Consolidation, eds. Matthew Sussex and Roger E. Kanet (New York: Palgrave MacMillan, 2015), p. 91-111 Ziegler, Charles E., "Central Asia, the Shanghai Cooperation Organization, and American Foreign Policy from Indifference to Engagement," Asian Survey 53(3), 2013, p. $484-505$ 
VITA

ZENEL GARCIA

Born, Camaguey, Cuba

2005-2010

B.A., International Relations

Second Major: Asian Studies

Florida International University

Miami, Florida, USA

2012-2014

M.A., Asian Studies

Florida International University

Miami, Florida, USA

2014-2016

M.A., International Studies

Florida International University

Miami, Florida, USA

2012-2016

Teaching Assistant

Department of Politics and International Relations

Florida International University

Miami, Florida, USA

2016-2018

2014-2018

Doctoral Candidate

Department of Politics and International Relations

Florida International University

Miami, Florida, USA

Adjunct Faculty

Department of Politics and International Relations

Florida International University

Miami, Florida, USA

2017-2018

Faculty Fellow

Honors College

Florida International University

Miami, Florida, USA

\section{PUBLICATIONS AND PRESENTATIONS}

Garcia, Zenel, (2017). "Strategic Stability in the 21st Century: The Challenge of the Second Nuclear Age and the Logic of Strategic Interdependence," Comparative Strategy 36(4), 354-365 
Garcia, Zenel \& Chand, Bibek, (2018). "Power Politics and Securitization: The Emerging Indo-Japanese Nexus in Southeast Asia," Asia and the Pacific Policy Studies 4(2), 310-324

Garcia, Zenel \& Breslin, Thomas A., (2016). "Biting the Cow's Tongue: Securitization and Capacity Building in the South China Sea," Journal of Asian Security and International Affairs 3(3), 269-290

Garcia, Zenel, (2016). "Power Cycles and Security Complexes: Evolution of the East Asian Supercomplex," Asia Politics \& Policy 8(4), 538-558

Garcia, Zenel, (2016). "A 'Normal' Japan and the Externalization of China's Securitization," Japan Studies Review Vol. XX, 157-178

Garcia, Zenel, (2016). "Resistance and Assimilation: Transforming Security Roles of China's Largest Muslim Minorities," Journal of Muslim Minority Affairs 36(2), 282-293

Review of James Manicom (2016): Bridging Troubled Waters: China, Japan and Maritime Order in the East China Sea, Asia Politics \& Policy 8(3), 502-504

Review of Christopher Davidson (2015): The Persian Gulf and Pacific Asia: From Indifference to Interdependence, Journal of Global South Studies 32(2), 267-269

Garcia, Zenel, (July 2018). The South China Sea and the Struggle for Regional Order. Presented at the Association for Asian Studies AAS-in-Asia Conference 2018, held in Delhi, Republic of India

Garcia, Zenel, (April 2018). The South China Sea as the Pivot: Competing Visions of Regional Order. Presented at the International Studies Association Annual Convention 2018, held in San Francisco, California

Garcia, Zenel, Roundtable (March 2018): China in the Post American World, presented at the Florida Political Science Association Annual Meeting 2018, held in Ft. Myers, Florida

Garcia, Zenel, Roundtable (March 2018): Intersections of Political Theory and International Relations. Presented at the Florida Political Science Association Annual Meeting 2018, held in Ft. Myers, Florida

Garcia, Zenel, (March 2018). Development and Securitization of Transboundary Rivers: A Case Study of Central Eurasia. Presented at the Florida Political Science Association Annual Meeting 2018, held in Ft. Myers, Florida

Garcia, Zenel, (November 2017). Re-connecting the Sub-Regions: China's Eurasian Foreign Policy. Presented at the International Studies Association Northeast Annual Conference 2017, held in Providence, Rhode Island 
Garcia, Zenel, (October 2017). People's War at Sea and China's Maritime Militia: From Strategy to Practice. Presented at the International Studies Association South Annual Conference 2017, held in Orlando, Florida

Garcia, Zenel, Roundtable (October 2017): Researching and Teaching International Relations during Politically Disruptive times, presented at the International Studies Association South Annual Conference 2017, held in Orlando, Florida

Garcia, Zenel, (June 2017). Securitization and the Changing Dynamics of Strategic Stability in the Indo-Pacific Region. Presented at the Association for Asian Studies AASin-Asia Conference 2017, held in Seoul, Republic of Korea

Garcia, Zenel, (June 2017). People's War and China's Maritime Peripheries: The Evolution of the Strategy and its Modern Application. Presented at the International Studies Association International Conference 2017, held in Hong Kong

Garcia, Zenel, (April 2017). Speech Acts and Securitization: Illocutionary and Perlocutionary Acts in the Study of Security. Presented at the Florida Political Science Association Annual Meeting 2017, held in Orlando, Florida

Garcia, Zenel, (February 2017). China and Eurasia: Evolving Policy and Regional Transformation. Presented at the International Studies Association Annual Convention 2017, held in Baltimore, Maryland

Garcia, Zenel, (February 2017). Securitization, Identity, and Role Dynamics: The South China Sea Territorial Disputes and the Struggle for Recognition. Presented at the International Studies Association Annual Convention 2017, held in Baltimore, Maryland

Fifteen other papers presented at the annual conferences of the International Studies Association (ISA), ISA-Northeast, ISA-West, ISA-South, Association for Asian Studies in Asia (AAS-in-Asia), Midwest Political Science Association, and Florida Political Science Association 